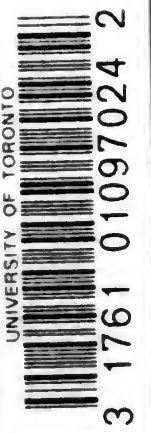

MHRXISM

VERSUS

SOCIALISM

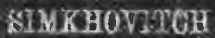



Digitized by the Internet Archive in 2007 with funding from

Microsoft Corporation 

MARXISM VERSUS SOCIALISM 


\section{SOCIALISM AND DEMOCRACY IN EUROPE}

\section{BY \\ SAMUEL P. ORTh, Ph.D.}

This volume traces briefly the spread of the Socialist Movement in England, France, Belgium, and Germany. It attempts to determine the relation of economic and political Socialism to democracy. The author has made extended visits to the countries studied. He has tried to catch the spirit of the movement by personal contact with the Socialist leaders and their antagonists, and by many interviews with the labour men themselves, so as to fully grasp the feeling of the rank and file. It is a condensed study of the history of Socialism and the present status of the movement, in the countries where it has made the most progress.

Now Ready. Cloth, 6/. net. 


\section{A R X I M VERS US S O C I A L I S M}

\section{VLADIMIR G. SIMKHOVITCH, Ph.D.}

Associate Professor of Economic History at Columbia University

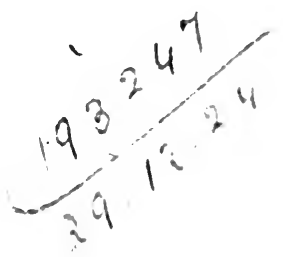

\section{LONDON}

WILLIAMS AND NORGATE

14, HENRIETTA STREET, COVENT GARDEN, W.C. 
Richard Clay and Sons, limited, BRUNSWICK STREET, STAMFORD STRRET, S.R., AND BUNGAY, SUFTOLK. 
TO THE MEMORY

OF

C. W. 



\section{INTRODUCTION}

THE reader who is interested in the spread and development of socialism here and abroad has undoubtedly noticed that the great growth of socialism in recent years has been accompanied by considerable changes in policy and doctrine. In the main, presentday political socialism is more or less Marxian, but the word socialist may mean anything. The American socialist, for example, will tell you that Marxism and socialism are synonymous, but what he will advocate is but partial state capitalism, or state ownership of the trusts. The German revisionist and the French reformist claim to be the spiritual heirs of Marx, and yet they have no illusions about the social revolution and the inevitable sudden collapse of the capitalist mode of production. Some revisionists, in fact, have grave doubts even as to the desirability of the expropriation by the state of all means of production. The syndicalists, on the other hand, who claim to be the only ones that act in accordance with Marx's class-struggle doctrine economically interpreted, have repudiated the political struggle. The rank and file of the American and German socialist parties claim to be Marxists, but even they are far less orthodox than they claim to be. They have toned down 
their Marxian doctrine as they have liberalized their policies. They have refrained from sacrilegiously revising Marx as a whole, but they have piously reinterpreted parts of his teaching-all with much loyalty to the memory of Marx, but with little respect for the intellectual consistency of the doctrine.

This situation is more than interesting, it is important. What is the cause of these changes? Why is it that so many of the socialist thinkers are so arduously revising and reinterpreting their traditional doctrine, while others are grasping for a new one? This book, I believe, answers the question. The Marxian doctrine, which helped the development of socialism throughout the world as no other doctrine ever did, has turned into a fetter, a trap, a pitfall from which there seems to be no escape. In the same compelling manner in which Marxism once assured its followers of the inevitability of the cataclysm and social revolution, precisely so does it indicate to-day their impossibility.

Marxian socialism, or "scientific" socialism, as Marx called it, differed fundamentally from the various types of socialism that preceded it. Marx ridiculed the invention of an ideal social organization. a perfect state. The fundamental proposition upon which Marx's socialism rested was his economic interpretation of history. This conception implied that the political and legal organization of society is absolutely dependent upon its economic structure, that our future 
depends entirely upon existing economic tendencies, that no social revolution could socialize scattered and decentralized industry, nor could legions of small property-owners be expropriated. On the other hand, no power on earth could prevent socialism, i.e., the expropriation of the means of production by society as a whole, if the economic tendencies were what Marx thought them to be when he was working out his doctrine.

Certain economic tendencies were, according to Marx, inherent in capitalism. These tendencies could but lead to the destruction of capitalism. They were: rapid concentration of production in industry and agriculture and the disappearance of small industrial and commercial undertakings; concentration of wealth in the hands of an ever diminishing group of magnates of capital, accompanied by the complete disappearance of the middle class and general proletarization of the masses; increasing misery of the proletariat accompanieg by an ever increasing class struggle; commercial crises of ever increasing magnitude, due to overproduction. Such were the tendencies that were to lead to the complete collapse of capitalism, to the social revolution and the dictatorhip of the proletariat. Under that dictatorship the means of production were to be expropriated and the socialist commonwealth inaugurated.

Before our law and our industry had more or less adjusted themselves to the introduction of machinery, 
all these tendencies actually existed. But when Marx formulated his doctrine, he failed to allow for counter tendencies, for society's ability to adjust itself to the new situation without a revolution.

It must be borne in mind that Marx did not advocate socialism because he believed the socialist state to be good. Socialism, in his opinion, was simply inevitable because of the economic tendencies inherent in capitalism. Were not such tendencies at work, socialism would have been an empty utopian dream, utterly lacking an economic basis and hence impossible of realization.

This is the keynote of Marxian socialism. Si non, non, is Marx's own proposition. Our contention is that nearly all the tendencies upon which Marx counted have failed him, and, consequently, that from the point of view of Marx's own economic interpretation of history the social revolution is but a revolutionary utopia.

It is quite true that the concentration of industry is very great, and there is little doubt in my mind that our gigantic industrial organizations will before long be effectively controlled in some way or other by governmental agencies. But even in this country, where industrial concentration has gone much further than elsewhere, it falls far short of the expectations of Marx. Constantly hearing of the mammoth combination, we quite naturally fail to notice the multitudes of petty enterprises which, humble though they may 
be, exist and flourish. Furthermore, Marx was quite mistaken in assuming that centralization of industry and concentration of management result in concentration of wealth, the disappearance of the middle class, and the final concentration of all capital in the hands of a very few magnates. The numbers of the rich and well-to-do have increased and are increasing by leaps and bounds. There has arisen a vast legion of stockholders who are the veritable national guard of capital. Politically they are anything but a negligible quantity. Nor have the small farmers disappeared from the face of the earth; on the contrary, wherever farming becomes intensive there is a tendency towards decentralization. A socialist state with the farmer outside it is a conception that can rest comfortably only in the head of an American socialist. In Chapter IV the reader will find that for Marx and Engels, to whom thinking was not an irrelevant foreign tradition, the disappearance of the farmer class was economically and politically a conditio sine qua non of the very possibility of a socialist commonwealth. Nor is the theory of increasing misery at all tenable. Indeed it is admitted that misery is decreasing instead of increasing. The condition of the working classes has greatly improved,-not as much, to be sure, as we should have desired, but enough to show that Marx was quite mistaken in assuming that the accumulation of misery must correspond to the accumulation of capital; that, to use Marx's own 
words, "accumulation of wealth at one pole is therefore at the same time accumulation of misery, agony of toil, slavery, ignorance, brutality, mental degradation, at the opposite pole." (See Chapter VI.)

In Chapter $\mathrm{X}$ of the present study the reader will discover how striking a rôle Marx allotted to commercial crises. They were to extend in magnitude and increase in frequency and momentum until the entire capitalist structure should crash and tumble. This cataclysm, which according to Marx is already overdue, was to result from that anarchy in production which characterizes the competitive system, which, he said, cannot produce without overproducing on an ever more gigantic scale. A dramatic and picturesque theory it was. As the revelation of a prophet it may still find believers, but as a scholarly theory it had to be abandoned even by Marx's own followers. In the third volume of Marx's Capital there is a frank admission that with the extension of the world market and quicker means of communication and transportation the tendency toward crises of overproduction has greatly diminished. Thus did the doctrine of the inevitable collapse of our capitalist system come to grief.

It is obvious to-day that the economic tendencies upon which Marx counted have played him false, and from the point of view of Marx's own economic interpretation of history the expectations and hopes of revolutionary socialism can hardly materialize. The situation has become quite evident to the clear minds 
within the socialist movement. This explains the revisionist, reformist, syndicalist and "back to Kant" socialist movements, besides many others that have recently arisen. To-day the social movement throughout the world is in one sense but a quest for a new possible meaning of the word socialism.

So-called scientific socialism is bankrupt. Socialists to-day have the alternative of becoming plain social reformers or of being out-and-out utopians. Not so, they say; even if all the mistakes of scientific socialism are admitted, its kernel remains sound and victory is assured. Why? Because, whereas the utopians were dreamers, Marx exposed class exploitation and taught class struggle, and under this sign a class-conscious proletariat will be victorious, and scientific socialism will win where utopias failed. Such statements we hear very often, and all that can be said in reply is this: If the assertion of Marx and Engels that all history is a history of class struggles is correct, there must have been quite a bit of class-consciousness in history before Marx; and yet these class struggles did not lead to socialism. With regard to so-called exploitation, our friends the socialists are making a mistake in looking down upon their unsuccessful forerunners, the utopians. In the last chapter of Thomas More's Utopia, from the title of which, if I am not mistaken, the word utopian has been derived, our friends will find the following observation:

"Therefore I must say, that as I hope for mercy, 
I can have no other notion of all the other governments that I see or know, than that they are a conspiracy of the richer sort, who, on pretense of managing the public, do only pursue their private ends, and devise all the ways and arts that they can find out; first that they may, without danger, preserve all that they have so ill acquired, and then, that they may engage the poorer sort to toil and labor for them, at as low rates as is possible, and oppress them as they please." 1

The scientific socialists have forgotten that More the utopian made such a statement. They would hardly have forgotten if it had materially affected economic conditions. It did not. Why, then, should we expect so much from Marx's formulation of precisely the same thought? Is it not rather utopian to expect so much in the way of fundamental changes in our social institutions from a formula, a thought, a conception, an idea?

No doubt it will be pointed out to us that the underlying economic conditions have changed since the days of More's Utopia. That is quite true; but to contend that further changes are to be expected because of our economic conditions is to shift the argument and return again to present-day economic tendencies, which have ceased to be encouraging from the Marxian point of view.

${ }^{2}$ More, Utopia (Bishop Burnet's translation), London, 1684, p. 201 . 
Of the various doctrines of Marx, the economic interpretation of history has suffered least from the ravages of time and of criticism. It is a very important theory, and it marked a great advance in historical methodology and social philosophy. But only a layman could regard this method as a perfect instrument. Much as I admire the theory, as perhaps the most robust ever advanced, it is at the same time the crudest and most unfinished doctrine in the field of social philosophy.

For, to begin with, there is no such thing as one economic interpretation of a given historical event; many interpretations are possible. One man may look upon certain economic conditions as the cause of the event, while another will find the cause in quite different economic aspects. The past presents nearly as varied a selection and almost as complete a chaos of economic influences as does the present, and therefore, even on the basis of the strictest economic interpretation, many combinations of causation are quite possible. Again, how can we determine, quantitatively and qualitatively, the strength of these economic influences with which we are dealing? And even assuming that historical laws have the same validity as the laws of mechanics, how much, after all, can they tell us? Every hovel and every bridge and every cathedral stands because it is constructed in accordance with mechanical laws. But do mechanical laws determine the designs of these various structures? Sim- 
ilarly within the laws of economic cohesion an endless variety of historical designs and structures is possible. Furthermore, we are apt to forget that the economic interpretation of history can explain only the changes that occur in things, never the things themselves. It might explain a change in religious doctrine, for instance, but never faith itself.

And if this doctrine, as a historical method of dealing with the past, where the game is played with open cards, is beset with such difficulties, how could one seriously expect much from it where the future is concerned? I am indebted to Professor Goodnow for an illustration of the uncertainty of our ordinary political forecasts. As we all know, the democratic development of our form of government has been attributed to the economic preëminence of the cities, the concentration of industrial population, etc.; and because of these modern economic conditions we expect still greater democratization of our governmental institutions. But it so happened that on September I2, I900, a gale drove the waves of the Gulf over the city of Galveston. In sheer despair all traditional political theory of separation of powers, etc., was abancloned, and to meet an extraordinary situation a commission form of government was adopted by the city. This entirely unforeseen and unexpected commission form of city government has since swept the country, one city after another adopting it throughout the United States. Of course it is easy to interpret 
this phenomenon economically a posteriori, but no economic interpreter could ever have foreseen so curious and extraordinary a development.

Because of this uncertainty of the things of the future, the writer of this book studiously refrains from prophecy. There is no assertion here that socialism is impossible in the future. The book deals with the well-known doctrine that because of such and such economic conditions social revolution is inevitable. Facts and figures show us that actual conditions do not warrant any such assumption. Neither with the naked eye nor with the help of such instruments as science may lend us can the socialist state be seen on the horizon. What may happen in the distant future we do not know; it lies absolutely and entirely beyond the realm of our knowledge, in a region where faith and imagination may reign supreme.

I cannot close this introduction without expressing my deep gratitude to those of my friends who have helped me in my struggle with English expression. I am especially indebted to Mrs. Simkhovitch, who, I fear, has taken time from her much more important work to lend me assistance. Both the form and the substance of the chapters relating to the class struggle were revised by that realistic genius, my late friend Miss Carola Woerishoffer. My friend and colleague, Professor Munroe Smith, as editor of the Political Science Quarterly, where this book first appeared in 
1908-12, has taken endless trouble in making it more or less readable,--for which I am profoundly grateful to him.

Vladimir G. Simkhovitch.

Greenivich House, New YoRk City. 


\section{CONTENTS}

CHAPTER
PAGE INTRODUCTION • • • • • • • • • • v

I. Popular Misunderstandings About the Róle of MarX's Theory of VAlUe . . . . . I

II. Marxian Soctalism in OUtuine . • • • . I3

III. The Economic Interpretation of History • $\quad 25$

IV. Concerning Concentration of Production in InDUSTRY AND AGRiculture . . . . . 47

V. Concerning the Disappearance of the Midde Class . . . . . . . . . 70

VI. The Throry of Increasing Misery . . . . . 98

VII. Data Relating to the Status of the Wage-earner 128

VIII. Class-struggle Conceptions. Forerunners of Marx 147

IX. The Marxian Class-struggle Doctrine . • . 185

X. The Theory of Crises . . . . . . 225

XI. The Social Revolution and the Inevitable

Cataclysm . . . . . . . . . $24 \mathrm{I}$

XII. Thz Collapse of Marx's Theory of Valur . 254

XIII. Marx's Attitude Towards Etrrnal Justice. ConCluding Remarks • • • • • • • 278

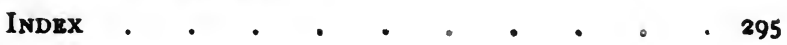




\title{
MARXISM VERSUS SOCIALISM
}

\author{
CHAPTER I
}

\section{POPULAR MISUNDERSTANDINGS ABOUT THE RÔLE OF MARX'S THEORY OF VALUE}

THE rôle which socialism is playing in the modern world and the extent to which the socialistic army in all civilized countries is marching under the banner of Karl Marx give to the body of doctrines which bear his name a unique position in social science. Even if the Marxian system be regarded as a tissue of errors, the fact that millions of men accept it makes it significant. It has, however, another claim upon the attention of the economist. Had Marxism failed to win a single adherent, it would still have been necessary for every serious student of economic theory to endeavor to understand it, for it contains a challenge that can be neither ignored nor evaded.

The literature of protest against Marxism is already vast, yet, with the notable exception of such writings as those of Böhm-Bawerk, Seligman, Sombart and Stammler, who have dealt with special aspects of the system, the bulk of that literature proves con- 
clusively to the well-informed reader that reason is but a fig-leaf for emotion. Too obvious in most instances is the critic's desire to emulate St. George and slay the dragon, even if personal modesty clothes the brave onslaught in the humble garb of scientific research. ${ }^{1}$ With these critics emotions run riot. They have in their zeal attempted the impossible: to kill the dragon without seeing him. That even St. George could not have done. ${ }^{2}$ Such criticism, carried on for two generations, has naturally established a tradition: a man of straw has been constructed for the express use of Marx's critics.

Of the current misconceptions of the Marxian system, the most fundamental and most general is the opinion that the labor-theory of value is the cornerstone of Marxian socialism. From this is derived the equally erroneous opinion that Marx's demand for social justice stands or falls with his theory of value.

${ }^{1}$ Marx, who, as Pierre Leroux once said about him, "had a keen understanding of the bad side of human nature," has given to the motives of his critics a somewhat unkind interpretation. "In the domain of political economy," he writes, "free scientific inquiry meets not only the same enemies as in all other domains; the peculiar nature of the material it deals with summons as foes into the field of battle the most violent, mean and malignant passions of the human breast, the Furies of private interest." Marx, Capital, fourth English edition (London, I89r), p. xix.

'As early as 1895 Adolph Wagner pointed out that most of the critics of so-called scientific socialism had shown that they had not the least conception of what they were talking about. See Die akademische Nationalökonomie und der Socialismus (Berlin, 1895), pp. 22, 23. 
Or, as a recent Marx critic, Mr. J. E. Le Rossignol, professor of economics in the University of Denver, puts it: "Orthodox socialists are deeply concerned to prove it true, for if it can be shown that all values are created by labor alone, it must surely follow that all should belong to the hand and brain that created them." 3 This ethical interpretation of the Marxian theory of value and the desire to base socialism upon this theory are characteristic of the bulk of the academic literature about Marx. Thus Professor Foxwell writes about Professor Menger: "For him [Menger] Marx, not Ruskin, is the type of the socialist. Socialism in this sense, the only one really distinctive, has been well defined by Mr. Rae, in terms which Dr. Menger might have drafted himself: ' It is not a theory of the state's action, but a theory of the state's action founded on a theory of the laborer's right-at bottom a demand for social justice-that every man shall possess the whole produce of his labor." " Giving to the Marxian system this interpretation, Professor Menger was logically justified in making the courageous statement that "Marx is far inferior to Thompson, so that the work of the latter may be regarded as the foundation stone of socialism." " This statement is exceedingly interesting. It

- Le Rossignor, Othodox Socialism, A Criticism (New York, 1907), p. 15.

-H. S. Foxwell, Introduction to Anton Menger, Right to the Whole Produce of Labor (London, 1899), p. xvii.

- Menger, op. cit., p. 102. 
proves that by making an ethical labor-theory of value the spring and center of Marxism socialism, one eo ipso wipes out the difference between the sentimental, utopian socialism of the first half of the last century and modern so-called scientific socialism. Most of the academic writers have attributed to Marxian theory precisely this sentimental character, but without drawing the logical conclusions.

What meaning then, the economist will justly ask, has Marx's theory of value? The answer is simple. Marx's theory of value occupies in his economic system the same position that the theory of value has occupied or has tried to occupy in many other systems. The classical systems of political economy were all metaphysics of commodities, philosophies of production and circulation. In Marx's metaphysics of production the theory of value occupies the same central position as the Substanz-problem in philosophical systems. This analogy is striking even in the phraseology of Marx. Marx is a realist, even a materialist, and is consistently, passionately, and naively so; but where he is dealing with a problem the very existence of which could not be recognized by a strict and consistent realism, he has to fall back on mediæval scholasticism. Observe his language: "I quarter corn $=\mathrm{x}$ cwt. iron. What does this equation tell us? It tells us that in two different things-in I quarter of corn and $x$ cwt. of iron-there exists in equal quantities something common to both. The two things must therefore be 
equal to a third, which in itself is neither the one nor the other. - . Let us now consider the residue of each of these products; it consists of the same unsubstantial reality in each, a mere congelation of homogeneous human labor, of labor-power expended without regard to the mode of its expenditure. All that these things now tell us is that human labor-power has been expended in their production, that labor is embodied in them. When looked at as crystals of this social substance, common to them all, they are Values." " That is written by Marx the materialist and sworn to by Engels-the same Engels who was so vastly amused by Kant's "Ding an sich," and who instructs us that chemistry in its recent progress has put an end to such mysterious entities.?

Whatever the faults and merits of Marx's theory of value may be, it was not intended as an ethical basis for socialism, but as a means of interpreting economic phenomena. It is quite true that his theory of value is the central theory upon which his economic analysis of the capitalistic system rests,-in short, the foundation of his economic doctrine; but this theory plays no rôle whatsoever in his socialistic doctrine, which purports to be nothing more than a demonstration that socialism is inevitable.

Marx's socialistic doctrine is intensely realistic. He

- Marx, Capital, English translation, pp. 3, 4, 5. The italics are mine.

'Engers, Socialism, Utopian and Scientific (Chicago, 1905), p. xvii. 
describes the existing economic phenomena and argues that the sum of these phenomena is bound to result in the expropriation of the means of production, in socialism. In this argument he deals with the economic phenomena historically, i.e., he does not analyze them philosophically, but treats them as existing powers, and he expounds their political and social effects, which he regards as necessary and unavoidable. The key to his socialist doctrine is the economic interpretation of history with the class-struggle doctrine following in its train. Accordingly, the doctrine of modern so-called "scientific" socialism is found in all its completeness in the Communist Manifesto, which contains no reference to any theory of value. It is, on the other hand, when Marx is at work analyzing and explaining the economic phenomena of capitalistic society that his ingenious theory of surplus value is elaborated. This theory is to him the key-word by which we are enabled to decipher and comprehend all economic phenomena. It must always be remembered that, from Marx's viewpoint, the actual economic phenomena are motive powers of society determining its future. No analysis or interpretation of these phenomena, whether it be scientific or unscientific, increases or diminishes their sovereign power. Interpretation affects them no more and no less than a volume on astronomy affects the solar system.

How then did it happen that it was the theory of surplus value that primarily drew the fire of the 
learned economists; and why did most of them seem to think that in disproving that theory they had delivered a mortal blow to modern socialism? First of all, perhaps, because certain socialist agitators tried to make emotional capital out of the theory of surplus value. This circumstance cannot, however, serve as an excuse for scholars who have undertaken to criticise Marxian socialism. Even if they deemed it unnecessary to study Marx's own writings, they could have learned from many a propagandist leaflet ${ }^{8}$ what rôle the theory of surplus value actually plays in the Marxian system. Secondly-and this probably furnishes in most cases the truer explanation of their misconceptions-they were not sufficiently impressed by the peculiarities of Marxian socialism to be disposed to draw a sharp line

- For instance, see Paul Fischer, Die Marx'sche Werttheorie, Berliner Arbeiterbibliothek, Serie I, Heft 9 (Verlag des Vorwärts, I893), pp. 33, 34: "The bourgeois economists have declared that Marx's theory of value is the bulwark by which socialism must stand or fall. . . . In almost all criticism of the fundamental principles of Marx's system the question of the correctness or incorrectness of the theory of value is reduced to the alternative of either throwing over Marx's theory of value or of throwing over society! . . . They foist this meaning of theirs on Marx sans fason. As they themselves imagine that a theory of value can have direct influence on the development of society, without more ado they presuppose the same idea on the part of Marx. Taking their own general economic point of view as the measure of Marx's theory, they commit the colossal mistake of considering the theory of value not only as the prerequisite of his criticism of bourgeois economy, but also as the foundation of his socialistic claims. They therefore entirely mistake the rôle which the theory of value plays." The italics are mine. 
between the socialism of Marx and the socialism of his predecessors. It seemed to them, probably, like making two bites of a cherry: socialism is socialism, and its variations are but differences in shade. All pre-Marxian socialism was distinctly ethical; every peroration against capitalism contained or implied an appeal for social justice. Whenever the word "exploitation" was used, they accordingly thought themselves justified in looking for the usual end of the sermon. When Marx, in his Capital, describes the development of the English factory system, he does not mince matters. He makes the respectable English blue-books, to use Bernard Shaw's phrase, convict capital "of wholesale spoliation, murder and compulsory prostitution; of plague, pestilence and famine; of -battle, murder and sudden death." " The citation of those deplorable facts and the energy of Marx's language struck some gentle scientific souls as an appeal for socialism. Add the circumstance that the first part of Marx's bulky volume was devoted to the elaboration of his theory of surplus value-a theory anything but complimentary to the capitalistic organization of society-and how could there be any doubt that Marx's doctrine is an ethical appeal for justice, and that the theory of value is its foundation? And if the Marxian theory of value be the foundation of a social movement that is growing so rapidly, then to

- Fabian Essays in Socialism, edited by G. Bernard Shaw, pp. $220,221$. 
destroy socialism one has only to destroy the labortheory of value. Thus it is that we are blessed with so large a literature on the Marxian theory of value.

In vain did Marx's co-worker and literary executor, Frederick Engels, protest against the putting of such an interpretation upon the theory of value. As early as 1884 Engels wrote: "This application of the $\mathrm{Ri}$ cardian theory, according to which the whole social product belongs to the sole producers, the workers, as their product, leads directly to communism. This theory, however, as Marx has pointed out, is from an economic point of view formally false, since it is an application of ethics to economics. According to the laws of the bourgeois economy the greater part of the product does not belong to the workers who have produced it. Now if we should say that it is unjust that this should be so, in the first place this does not concern economics. All that we can say is that this - economic fact contradicts our moral sentiment. Upon this, therefore, Marx never based his communistic demands, but upon the inevitable catacylsm of the capitalistic mode of production, which is going on before our eyes." 10 Marx himself emphasizes the same thought in different ways on all sorts of occasions. For example, in his Capital he criticises, in Proudhon, precisely that ethical attitude which the critics of

10 Karl Marx, Das Elend der Philosophie, deutsche Uebersetzung, 2te Auflage (Stuttgart, 1892); Friedrich ENGELS, Vorwort, p. ix. 
Marx attribute to Marx himself. "Proudhon begins by taking his ideal of justice, of ' justice éternelle,' from the juridical relations that correspond to the production of commodities. . . Then he turns around and seeks to reform the actual production of commodities, and the actual legal system corresponding thereto, in accordance with this ideal. What opinion should we have of a chemist who, instead of studying the actual laws of the molecular changes in the composition and decomposition of matter, and on that foundation solving definite problems, claimed to regulate the composition and decomposition of matter by means of the 'eternal ideas' of 'naturalité' and 'affinité'? Do we really know any more about ' usury,' when we say it contradicts ' justice éternelle,' 'équité éternelle,' 'mutualité éternelle' and other 'vérités éternelles' than the fathers of the church did when they said it was incompatible with ' grâce éternelle,' 'foi éternelle' and 'la volonté éternelle de Dieu'?" 11 Not only does Marx himself avoid appeal to ethical ideas, but the entire plan on which his system is constructed obliges him to take a non-ethical attitude toward economic phenomena. Does he not justify capitalism by emphasizing its absolute necessity? In the preface to his Capital he quotes with approval a Russian critic who has clearly apprehended his main idea. This critic tells us that Marx is trying to prove " both the necessity of the present order of ${ }^{11}$ Marx, Capital, English ed. (London, 1891), vol. i, p. 56. 
things and the necessity of another order into which the first must inevitably pass over, and this all the same, whether men believe or do not believe it, whether they are conscious or unconscious of it. Marx treats the social movement as a process of natural history, governed by laws not only independent of human will, consciousness and intelligence, but rather, on the contrary, determining that will, consciousness and intelligence." 12 How could such an attitude be reconciled with a plea for another social order on any moral ground, e.g., on the ground that the worker is not getting the whole produce of his labor? ${ }^{13}$

12 Ibid., pp. xxvii, xxviii.

"Sombart was absolutely right in what he had to say about Professor Julius Wolf's book on Socialism, and some of his charges hold good as regards nearly the whole critical literature on Marx, not excepting the most recent publications. Special attention should be paid to the following paragraph in Sombart's criticism: "Wolf makes Marxism almost the sole object of his attack, although with fatal carelessness he nowhere clearly distinguished it from other socialistic systems. The possibility of a correct understanding of any one of the principal Marxian doctrines, however, was destroyed as soon as the critics failed to realize the purely theoretical character of Marxism. In the fact that Wolf gives an ethical import to Marx's doctrine, makes it.

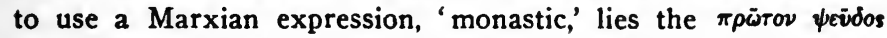
of all the critical deductions of the book in question. Wolf ought to have understood first and foremost that Marxism is distinguished from all other socialistic systems (which in contrast to him I propose to sum up under the heading of ethical socialism) by its anti-ethical tendency. In the entire Marxism from beginning to end there is not a particle of ethics and consequently no more of an ethical opinion than an ethical postulate. Marx maintains in no place either that the surplus value does not belong to the employer or that the workman 'has a right to 
the whole produce of his labor.' A great part of Wolf's criticism, however, consists in a disquisition to Marx on what is 'proper' and what is 'improper' in the present-day mode of production, and distribution of revenue. . . And finally, to sum up, he says: 'All theory and practice of socialism, according to the conception of socialism, presupposes the right to the whole product of labor.' Had Wolf added, 'with the exception of Marxism,' he would have hit upon the truth. By including Marxism he made his weightiest critical attacks futile." BRAUN's Archiv für soziale Gesetzgebung und Statistik, 1892, vol. v, pp. 489, 490. 


\section{CHAPTER II}

\section{MARXIAN SOCIALISM IN OUTLINE}

"IN Brussels," Marx writes, " where I was exiled by Guizot, I organized, together with Engels, W. Wolff and others, a German 'Arbeiterbildungsverein,' which still exists. We published at the same time a series of printed and lithographed pamphlets, in which we criticised mercilessly that mixture of French-English socialism or communism with German philosophy which then formed the doctrine of the 'Bund.' I Instead of that we postulated scientific insight into the economic structure of civil society [bürgerliche Gesellschaft] as the only defensible theoretical basis of socialism. We also explained, in a popular form, that it is not a question of putting through some utopian system, but of taking a conscious part in the process of social transformation which is going on before our very eyes. . . . In the manifesto written for workingmen I discarded all systems and put in their stead a critical insight into the conditions, prog-

"Marx is referring to the "Bund der Kommunisten." The history of that organization and an account of the relations of Marx and Engels to it may be found in Engels's preface to KarL. MARX, Enthüllungen über den Kommunistenprocess in Köln (Nottingen-Zürich, 1885), pp. 3-17. 
ress and general results of the actual social movement." 2 This is Karl Marx's testimony in his own behalf as to the origin and scope of his socialistic doctrine. What did he mean by a critical insight into the conditions of this social movement? What was the fundamental proposition of the Communist Manifesto, which is the first outline of modern scientific socialism? Let us again listen to the testimony of one of the authors: "The Manifesto being our joint production," writes Engels, " I consider myself bound to state that the fundamental proposition which forms its nucleus belongs to Marx. That proposition is: that in every historical epoch, the prevailing mode of economic production and exchange, and the social organization necessarily following from it, form the basis upon which is built up, and from which alone can be explained, the political and intellectual history of that epoch." 3 And it is not merely for explanation of the

${ }^{2}$ KarL MaRx, Herr Vogt (London, 1860), pp. 35, 42.

'Engels's preface to the Communist Manifesto, English edition (Chicago, Chas. H. Kerr and Company), p. 8. This conception of the economic interpretation of history was for the first time adequately formulated by Marx a decade after the appearance of the Manifesto in his Zur Kritik der politischen Oekonomie, published in 1859. Those passages are so important that we quote them here in full: "In the social production which men carry on, they enter into definite relations that are indispensable and independent of their will; these relations of production correspond to a definite stage of development of their material powers of production. The sum total of these relations of production constitutes the economic structure of society-the real foundation, on which rise legal and political superstructures and to which correspond definite forms of social consciousness. 
past that we are to look to the mode of production and exchange; for these processes now determine and will continue to determine all our intricate social relations, all our ideal conceptions. With them lies our fate: they have decided upon our past and they will settle our future. The conditions and contingencies

The mode of production in material life determines the general character of the social, political and spiritual processes of life. It is not the consciousness of men that determines their existence, but, on the contrary, their social existence determines their consciousness. At a certain stage of their development, the material forces of production in society come into conflict with the existing relations of production, or-what is but a legal expression for the same thing-with the property relations within which they had been at work before. From forms of development of the forces of production these relations turn into their fetters. Then comes the period of social revolution. With the change of the economic foundation the entire immense superstructure is more or less rapidly transformed. In considering such transformations the distinction should always be made between the material transformation of the economic conditions of production, which can be determined with the precision of natural science, and the legal, political, religious, æsthetic or philosophic-in short ideological-forms in which men become conscious of this conflict and fight it out. Just as our opinion of an individual is not based on what he thinks of himself, so can we not judge of such a period of transformation by its own consciousness; on the contrary, this consciousness must rather be explained from the contradictions of material life, from the existing conflict between the social forces of production and the relations of production. No social order ever disappears before all the productive forces for which there is room in it have been developed; and new higher relations of production never appear before the material conditions of their existence have matured in the womb of the old society." KarL Marx, A Contribution to the Critique of Political Economy, English translation by N. S. Stone, pp. II, I2. 
of social production have divided society into classes, and all the history of hitherto existing society is a history of class struggles. "Freeman and slave, patrician and plebeian, lord and serf, guildmaster and journeyman, in a word, oppressor and oppressed, stood in constant opposition to one another, carried on an uninterrupted, now hidden, now open fight-a fight that each time ended either in a revolutionary reconstruction of society at large or in the common ruin of the contending classes." 4

The modern "bourgeois" society, according to Marx, has grown up on the ruins of the feudal society. The discovery and colonization of the new world, trade with the East Indies and the general development of the means of exchange gave to commerce and industry an impulse never before known. The feudal organization of society was too narrow to hold within its limits modern industry and commerce even in their infantile stages. The feudal restrictions were burst asunder. The rule of the aristocracy was pushed aside and the modern bourgeoisie took its place in political life. The bourgeoisie as a class has played a most revolutionary rôle. Just as conservation of the old mode of production was the condition of existence of the feudal society, so constant technical improvement, constant advance, constant revolutionizing of the instruments of production have become capitalism's very breath of life. "The bourgeoisie has disclosed how

- Communist Manifesto, p. 12. 
it came to pass that the brutal display of vigor in the Middle Ages, which reactionists so much admire, found its fitting complement in the most slothful indolence. It has been the first to show what man's activity can bring about. It has accomplished wonders far surpassing Egyptian pyramids, Roman aqueducts and Gothic cathedrals; it has conducted expeditions that have put in the shade all former exoduses of nations and crusades." : The constant revolutionizing of production is accompanied by an uninterrupted agitation and disturbance and is followed by a constant change in social conditions-a circumstance which distinguishes the capitalistic era from all other epochs in human history. No frozen relations, no venerable prejudices for our age! Prejudices have no chance to become rooted, opinions have no chance to ossify. They are swept away before they are antiquated in this whirlwind of industrial progress. Industry has lost its national character. The need of larger markets chases the capitalist over the surface of the globe; it forces him to settle everywhere, to establish connections everywhere. On pain of extinction it compels nations to drop their ancient traditions and to adopt the capitalist mode of production and the bourgeois conception of the world. Cheap commodities batter down all Chinese walls, and the bourgeois creates a new world after his own image. Class issues and class struggles are therefore losing their national char-

$$
\text { 'Ibid., pp. 16, } 17 .
$$


acter, they are becoming as cosmopolitan as the bourgeoisie and its capitalist mode of production! The capitalistic centralization of means of production is bringing about centralization of the scattered population: it has brought the laboring masses into towns. The extensive use of machinery has stripped work of all its individual character; the laborer's personality fades in the factory, where he becomes a mere appendix to the machine during the day; nor can his sense of separate existence be cultivated in the dingy tenement house quarters, where he is packed for the night. (The more readily, therefore, do these multitudes merge into one solid class, the proletariat, conscious of its separate class existence, with tasks, aims and destinies widely different from those of the bourgeoisie, the class that owns the means of production.

The bourgeoisie, being, as we have seen, a highly progressive class, finds itself involved in constant political struggles. In the early stages of its development it has to fight with the aristocracy for political supremacy. Later on its finds itself involved in a struggle with those portions of the middle class whose interests have become antagonistic to the progress of industry. In all these struggles the bourgeoisie has to appeal to the laboring class, to the proletariat, for help and support. Thus the laboring class is drawn into the political arena. There it is supplied with the elements of political education-weapons which are destined to be turned against the ruling class. 
But that is not all. (The very progress of capitalist production and accumulation increases the numbers and the political strength of the proletarians and depletes the ranks of the natural defenders of capitalism Property makes for conservatism; but industry and commerce rapidly destroy the property of the small tradespeople, shopkeepers, handicraftsmen and farmers. All these are doomed to sink into the proletariat, partly because they have not sufficient capital for the scale on which modern industry, commerce and agriculture are carried on, partly because they are swamped by the competition of large capitalists, partly because their special skill is rendered worthless by modern methods of production. These proletarians, instead of rising with the progress of industry, sink deeper and deeper. In the past, we are told by the authors of the Communist Manifesto, existence was assured to the oppressed classes, in order that the oppression might continue; they also had a chance to rise and thus raise their own class. The ser $f$ in the period of serfdom managed to raise himself to membership in the commune; the burgher under feudal rule developed into the modern bourgeois. The proletariat, we are informed, has no such chances. "The modern laborer, on the contrary, instead of rising with the progress of industry, sinks deeper and deeper below the conditions of existence of his own class. He becomes a pauper, and pauperism develops more rapidly than population and wealth. And here it becomes evident 
that the bourgeoisie is unfit any longer to be the ruling class in society, and to impose its conditions of existence upon society as an overriding law. It is unfit to rule, because it is incompetent to assure an existence to its slave within its slavery, because it cannot help letting him sink to such a state that it has to feed him instead of being fed by him." ${ }^{\circ}$

Capitalism,-we are told, is not only threatening the very life of the proletariat, it is undermining its own existence. Capitalistic society is rapidly approaching a complete cataclysm. Modern society, having called into existence unparalleled means of exchange and gigantic means of production, is like the sorcerer who can no longer cope with the powers of the nether world which his incantations have conjured up. For decades we have been witnessing a distinct rebellion of the modern forces of production against the conditions of production, i.e., property conditions, property relations. This rebellion finds expression in the periodical return of that modern epidemic, the commercial crisis, which is threatening more and more the whole bourgeois society. And all the misery that accompanies such a crisis is due to overproduction. The masses of the people are in want of the means of subsistence because too much has been produced! The forces of production let loose, spurred by wild competition, are here fettered by the narrowness of the bourgeois property relations. "As a matter of

- Communist Manifesto, p. 31. 
fact," writes Engels, " since 1825, when the first general crisis broke out, the whole industrial and commercial world, production and exchange among all civilized peoples and their more or less barbaric hangers-on, are thrown out of joint about every ten years. Commerce is at a standstill, the markets are glutted, products accumulate, hard cash disappears, credit vanishes, factories are closed, the mass of the workers are in want of the means of subsistence, because they have produced too much of the means of subsistence; bankruptcy follows upon bankruptcy, execution upon execution. The stagnation lasts for years; productive forces and products are wasted and destroyed wholesale, until the accumulated mass of commodities finally filters off, more or less depreciated in value, until production and exchange gradually begin to move again. Little by little the pace quickens. It becomes a trot. The industrial trot breaks into a canter, the canter in turn grows into a headlong gallop, a perfect steeplechase of industry. And so over and over again. We have now, since the year 1825, gone through this five times, and at the present moment ( 1877 ) we are going through it for a sixth time." " The conquest of new markets and the more thorough exploitation of the old ones but pave the way for more extensive, more destructive, more formidable crises.

'Frederick Engers, Socialism, Utopian and Scientific, translated by E. Aveling (New York, 190I), pp. 4I, 42. 
In these crises the whole mechanism of capitalist production breaks down under the pressure of productive forces which the existing society can neither utilize nor harness. Thus capitalism stands convicted of incapacity further to direct these forces. The concentration of industry and of wealth, the proletarization of the masses, the deterioration of the proletariat, the increasing virulence of class struggles in politics and the increasing disastrousness of commercial crises -what do these developments indicate but the rapidly approaching cataclysm of the capitalistic mode of production? And what do they herald but the expropriation of the means of production by society as a whole?

The concentration of industry is already socializing production. The old anarchic production is gradually disappearing. The producers on a large scale in a particular branch unite in trusts, determine the total production and regulate the price. "In these trusts, freedom of competition changes into its very opposite -into monopoly; and the production without any definite plan of capitalistic society capitulates to the production upon a definite plan of the invading socialistic society. Certainly this is so far still to the benefit and advantage of the capitalists. But in this case the exploitation is so palpable that it must break down. No nation will put up with production conducted by trusts, with so barefaced an exploitation of 
the community by a small band of dividendmongers." 8

While the concentration of industry goes on, the capitalist mode of production completes the transformation of the majority of the population into proletarians, ${ }^{2}$ who under the penalty of their own destruction are bound to seize the political power and turn the socialized means of production into state property, thereby putting an end to their own misery, to the existence of a ruling class and to all class struggle. The final step will require a forcible overthrow of all existing social conditions. Then let the ruling class tremble before the coming of social revolution. The proletarians have a world to gain and nothing to lose but their chains. The proletarians do not indulge in utopias. They are not concerning themselves with the details of the future socialist organization of society; when the time comes, the very conditions of production will determine the mode of distribution. All that the proletarians are called upon to do is to take a conscious part in the inevitable class struggle. Their victory is foreordained. ${ }^{10}$

- Engers, op. cit., New York ed., p. 44.

Ibid., p. 48.

10 "The abandoning of private ownership of the means of production will become a necessity of nature through economic development. The same economic development, however, will, with like necessity, bring about a method of production which must and will take the place of the existing one. Indeed, whoever has eyes to see can already discern not only the shoot, 
These are the fundamental conceptions of Marxian socialism, of modern socialism, of so-called scientific socialism. This is the "common platform," to use the phrase of Engels, " acknowledged by millions of workingmen from Siberia to California." Let us look into these doctrines.

but also that it has grown fairly high." KARL KAUTSKy, Grundsätze und Forderungen der Sozialdemokratie, Erläuterungen zum Erfurter Programm (Berlin, 1892), p. 15. 


\section{CHAPTER III}

\section{THE ECONOMIC INTERPRETATION OF HISTORY}

MARXISm, as we have seen, claims to have little interest in pious wishes. Its " fundamental proposition" is the economic interpretation of history. ${ }^{1}$ In the light of this theory it examines contemporary economic tendencies, commercial crises, concentration of production, proletarization of the masses, the class struggle, etc., and comes to the conclusion that socialism, i.e., expropriation of the means of production by the working class in the interests of society as a whole, is inevitable and certain. It does not imagine

${ }^{1}$ Engels himself calls the economic interpretation of history the "fundamental proposition." That it is the fundamental proposition is of course evident from the whole system. Yet in Professor Le Rossignol's recent book on Orthodox Socialism we read: "And if it could by any possibility be shown that socialism, as a system of thought, is utterly untenable, the true socialist would retreat to his last stronghold, and say that socialism, in the last analysis, is not a system of thought, but a process of social evolution, a law of the industrial world irresistibly moving on toward its final destiny" (p. 5). What this author means by Marx's "system of thought" is not made evident; but it is clear that he fails to see that the economic interpretation of history underlies the Marxian system. It is this interpretation of history that furnishes the Marxian socialist with the "process of social evolution," which is not his last, but his first and last stronghold. 
that a new organization of society can be forcibly introduced before society is ready for it. Marx categorically states that " no social order ever disappears before all the productive forces, for which there is room in it, have been developed; and new higher relations of production never appear before the material conditions of their existence have matured in the womb of the old society." 2

How could Marx make such a statement, and yet believe in the imminent breakdown of capitalism, with socialism speeding on its trail? The answer is that the economic interpretation of history had for Marx and Engels in the middle of the last century quite a different meaning from that which even the most ardent and orthodox socialists can possibly give to it to-day. An incident narrated by Liebknecht in his reminiscences of Marx may serve as an illustration: "Marx, all flushed and excited, told me that during the last few days the model of an electric engine drawing a railroad train was on exhibition in Regent Street. Now the problem is solved-the consequences are indefinable. In the wake of the economic revolution the political must necessarily follow, for the latter is only the expression of the former." ${ }^{3}$ And poor Liebknecht could not sleep that night, for he saw the revolution coming. The model on Regent Street was

2MArx, A Contribution to the Critique of Practical Economy, translated by N. I. Stone, p. 12.

${ }^{3}$ Liebrnecht, Karl Marx, Biographical Memoirs (Chicago, 1906), p. 57. 
to him a Trojan horse, which the bourgeois society was leading in suicidal blindness into the citadel. Now the fate of capitalism was settled! That was in July, 1850. "And to-day is 1896 , the beginning of April," adds Liebknecht sadly. This incident gives an idea of the tempo in which Marx believed that social readjustments are bound to follow economic changes, the tempo in which all the "superstructures" of legal and political nature, all the "ideological" expressions of human consciousness, are dragged and driven by the material forces of production. In his belief the body of law that corresponds to a certain mode of production becomes not only antiquated but meaningless and invalid as soon as the mode of production changes. Marx did not express this merely as an academic proposition, he made it his defense when charged with agitating an armed rebellion. Before the court and jury of Cologne he pointed to the Code Napoléon and declared it to be no more binding than a stack of waste paper. It had lost for him its validity, because the economic conditions, to which it gave expression, had ceased to exist." A social revolution was therefore

- "Society, however, does not rest upon law. That is a legal fiction. Rather the law must rest on society. It must be the expression of the interests and needs of society which result from the social and invariably material method of production as against the arbitrariness of the individual. As for the Napoleonic Code, which I have in my hand, that has not engendered modern civil society. This society, which arose in the eighteenth century and developed in the nineteenth, finds in the Code only a legal expression. As soon as that no longer 
imminent. In the autumn of 1850 , in the magazine Die neue Rheinische Zeitung, Marx states with assurance: "A new revolution is possible only in consequence of a new crisis. The former, however, is as certain as the latter." 5 The crisis came and the crisis went, but there was no sign of a revolution. This tends to show that no matter how great a discovery, how true a doctrine the economic interpretation of history may be, it is not an altogether safe instrument for social forecasts. In 1895 , in his preface to Marx's Klassenkämpfe in Frankreich, Engels acknowledged the fact that he and Marx had altogether underestimated the strength and vitality of capitalistic society. "History has proven that we, and all that have thought similarly, were wrong. History has made it clear that the state of economic development on the continent was far from ripe for the abolition of the capitalistic mode of production." 6

For a prognosis of the future the economic interpretation of history is available only when the economic factor is the only one with which we have to corresponds to social conditions, it is merely so much waste paper. ... The laws necessarily changed with the changing conditions of life. The maintaining of the old laws against the new needs and demands of the social development is at bottom nothing but a hypocritical assertion (in accord with the spirit of the age) of special interests against the common interest." Karl Marx vor den Kölner Geschworenen (Berlin, 1895), p. 15.

'Literarischer Nachlass von Karl Marx und Friedrich Engels, 184I-1850, Bd. III (Stuttgart, I902), p. 468.

${ }^{\circ}$ Karl Marx, Die Klassenkämpfe in Frankreich, 1848-1850, mit Einleitung von Friedrich Engels (Berlin, 1895), p. 8. 
deal, when the other factors of social life are but feeble reflexes of the forces of production-naturae naturatae, to use Spinoza's expression-wholly incapable of exerting any independent influence. Then indeed the social organism is very simple, and social science can be reduced to a social mechanics. Did Marx actually carry his theory so far as this? As early as 1852, in The Eighteenth Brumaire of Louis Bonaparte, he acknowledges the power of traditions: "Man makes his own history, but he does not make it out of whole cloth; he does not make it out of conditions chosen by himself, but out of such as he finds close at hand. The traditions of all past generations weigh like an Alp upon the brain of the living." " But while such concessions can be found in Marx's writings, his interpretation of history was from the beginning rigidly and harshly economic. In later years Engels had to confess that he and Marx were partly responsible for the fact that their followers sometimes laid more stress on the economic side than, it deserved."

' Karr Marx, The Eighteenth Brumaire of Louis Bonaparte, translated by Daniel De Leon (New York, 1898), p. 5. Of course the German word Alp should have been translated "nightmare."

" "That at times more stress was laid by our followers upon the economic side than it deserved both Marx and I had in part to confess. We had to emphasize against our opponents this main tenet of ours which was denied, and there was not always time, place or opportunity to give the other principles their due. But when it came to the treatment of an historical proposition, there the situation was different and no error was possible. It is, however, only too frequently that men think 
He admits that all the so-called ideological superstructures exert an influence and are in constant interreaction. The economic cause is but their original and perhaps, very remote source. But still the economic factor is the predominant one. Thus Engels wrote in 1894 : "It is not that the economic situation is the cause, in the sense of being the only active agent, and that everything else is only a passive result. It is, on the contrary, a case of mutual action on the basis of the economic necessity, which in the last instance always works itself out." ${ }^{\circ}$

In the same letter Engels still further widens and modifies the economic interpretation. The geographical basis is included in economic relations, and " race is itself an economic factor." 10 Again we are told that all "the political, legal, philosophical, religious, literary and artistic developments rest upon the economic. But they all react upon one another and upon

that they have completely understood a new theory and are competent to use it without more ado as soon as they have mastered its main points, and that not always correctly. I cannot spare some of the later followers of Marx this reproach, and now and then most curious stuff was produced by them." This letter is dated September, 1890, and was first published in Der sozialistische Akademiker, October, 1895. It is here quoted from MASARYK, Philosophische und soziologische Grundlagen des Marxismus (Wien, 1899), p. 104.

- Letter in Der sozialistische Akademiker, quoted in Woltman, Der historische Materialismus (1900), p. 249. A portion of the letter is also reprinted in Seligman, The Economic Interpretation of History (New York, 1902), pp. 64, 65.

${ }^{10}$ Ibid. 
the economic basis." 11 This conception of history is very far from the original contention of Marx and Engels. It is doubtful whether this economic interpretation is methodology's last word, but it has stood its ground well. Scholarly criticism, like that of Stammler, Seligman and others, has considerably broadened and modified the theory but has not overthrown it.

The paramount importance of the economic factor in history has been practically conceded, but whether this new method will transform history into an exact science is exceedingly doubtful. One of the obstacles in the way of scientific history is the general desire of men for unscientific history. What social science can tell us with tolerable accuracy, viz., the broad, general changes in humanity's methods of work, in its conceptions and its institutions, does not satisfy us. It is life in terms of life that attracts us. We want books like The True Portraicture of His Sacred Majesty King Charles I in His Solitudes and Sufferings; we want to hear all about the personal life and influence of every mistress of Louis XIV; we want all the actors and puppets of history depicted and analyzed. It is scientifically impossible, but the impossible has to be done. Vox populi, vox Dei. Accordingly, the historian revivifies dead heroes and tells us more about them than he could truthfully state about his next-door neighbor, often more than he ${ }^{11}$ Ibid. The italics are mine. 
actually knows about himself. In doing so, however, he makes no freer use of his imagination than the theologian, the philosopher, the sociologist, or any talkative scientist in his particular branch of knowledge. Mephisto might have addressed them all:

"Is it the first time in your life you're driven To bear false witness in a case?

Of God, the world, and all that in it has a place, Of man, and all that moves the being of his race, Have you not terms and definitions given With brazen forehead, daring breast? And, if you'll probe the thing profoundly, Knew you so much-and you'll confess it roundly!As here of Schwerdtlein's death and place of rest?"

Quite so! And yet among the traits that humanity cannot lose without losing its identity are the "brazen forehead and daring breast"-in other words, the aspiration to know, to understand, to comprehend. Our conceptions have varied, so has our knowledge, but never our desire. The effort of thought and imagination to go beyond the limits of knowledge is only a part of our constant endeavor to overcome by intellect our physical disabilities. There are, in the history of such efforts, partial failures more inspiring than our most signal successes. A place of honor among such partial failures belongs to Marx's economic interpretation of history. It was an attempt 
to make an exact science of our past, to solve the problems of the present and to disclose to us with scientific precision our future. We have seen that the method has already lost the extreme simplicity which constituted its chief youthful charm. It is no longer simply economic; the independent power and influence of our traditions, our political and religious convictions and our various ideologies have been recognized; and no method has been discovered to measure quantitatively the forces of these ideal powers, either absolutely or in relation to the basic economic factor. Under these circumstances and in view of the complexity of the forces that must be taken into account, no scientific prognosis of our future is possible. In a general way we can of course discuss the probable political or social consequences of our present economic tendencies. There is nothing to hinder prophecy, but there is also no guaranty of its fulfilment. It has already been pointed out that the economic interpretation of history is of great value in analyzing the underlying conditions of a given historic epoch. Engels's amendments to the original formulation of the economic interpretation are so broad that it has entirely lost its original character of a cook-book recipe for making history. Even its name may be a misnomer, since traditions weigh and ideals count, and both modify the economic basis. But at least this much of it remains-its demand for a strictly realistic, consistent, causally connected history. In dealing with 
a social movement, a political event or a type of culture, the historian must causally explain its genesis. $\mathrm{He}$ cannot beg the question simply by appealing to some inborn traits and characteristics of the given decade or the given nation. These traits and characteristics must themselves be causally explained. But no explicit directions can be given for connecting a particular situation or event with particular precedent conditions or events. This is left to the judgment, discrimination and intuition of the historian. Of two historians, therefore, both adhering to the same method, one may prove himself an imbecile, the other a genius. The application of the method remains an art.

This is well illustrated by some of the writings of Engels. Here for instance is his explanation of the Protestant Reformation: "The bourgeoisie, for the development of its industrial production, required a science which ascertained the physical properties of natural objects and the modes of action of the forces of nature. Now up to then science had but been the humble handmaid of the church, had not been allowed to overstep the limits set by faith, and for that reason had been no science at all. Science rebelled against the church; the bourgeoisie could not do without science, and, therefore, had to join the rebellion." 12 So "bourgeoisie" and "science" are responsible for

${ }^{12}$ Engels, Socialism, Utopian and Scientific (New York, 1901), p. xxii. The italics are mine. 
the Protestant revolt. That is both new and startling! The exact date of the appearance of the " bourgeoisie" is nowhere definitely given by Marx or by Engels, but as to its approximate date they leave no doubt. In the Communist Manifesto we are told that the rule of the bourgeoisie has lasted "scarce one hundred years," 13 and that during the French Revolution the bourgeois epoch was still only "impending." 14 It therefore appears that the bourgeoisie was shaking Rome and remodeling religion some three hundred years before its epoch arrived. Still more remarkable is the activity attributed to science in the period of the Reformation. Science in the sense of Marx and of Engels did not then exist. Nor, in the preReformation period, was there anything like the later conflict between science and religion. There is no case on record in which the Church of Rome, before the Reformation, seriously interfered with learning. It had none of the organs of suppression which it later developed in such abundance. There was no index expurgatorius, and before the fifth Lateran Council there was no censorship of books. All new learning as a matter of fact was patronized by the worldly court of Rome. A certain amount of heresy was there considered a sign of good breeding. The air of Rome before the Reformation was certainly a great deal freer than that of Wittenberg and Geneva after

${ }^{12}$ Communist Manifesto, Kerr ed., p. 20.

10 Ibid., p. 59. 
the Reformation. The statement, therefore, that the Reformation was in its essence a rebellion of science against the church is ludicrous. There are no facts to support it. ${ }^{15}$

Neither the bourgeoisie nor science had anything to do with the Reformation. Nor was it a religious issue at the outset, but, as Mr. Henry C. Lea has pointed out, an economic issue. In the famous indictment of the papacy by Ulrich Hutten, addressed to Leo $\mathrm{X}$ in 1517 , there is not a single word about faith or doctrine. His "whole gravamen," as Mr. Lea observes, "consists in the abuse of power-the spoliations, the exactions, the oppression, the sale of dispensations and pardons, the fraudulent devices

${ }^{16}$ It is singular that Engels should not have perceived that the Protestant revolt was susceptible of a more direct and more plausible economic interpretation than that which he selected. Cf. Henry C. Lea, "The Eve of the Reformation," in The Cambridge Modern History, vol. i (New York, 1902), ch. xix, pp. 653-692. As a matter of fact the first to give an economic interpretation of the revolt was Luther himself. One has only to read his address, An den Christlichen Adel Deutscher Nation von des Christlichen Standes Besserung, to see that the Reformation was largely a protest against the fearful economic exploitation of Germany by the Church of Rome. Luther writes, for example: "How is it that we Germans are forced to suffer such theft and exploitation by the pope? . . . I think that Germany gives much more now to Rome and the pope than it did in former days to the emperors. Yes, many of us think that every year over 300,000 gulden go from Germany to Rome, purely in vain, and in return we get but derision and abuse. And then we wonder that princes, nobles, cities and monasteries, land and people, grow poor! We ought rather to wonder that we still have something to eat. . . If we hang thieves by law, 
whereby the wealth of Germany was cunningly transferred to Rome." 10

One cannot read the contemporary documents without being aware of the fact that the Protestant Reformation was a political revolution, chiefly incited by an economic grievance. It was a refusal of tribute to a foreign power. Mr. Lea shows that before the Reformation the most Catholic and orthodox states, like Spain and France and the Italian cities, were constantly on the verge of revolt against the papacy, and this on account of financial exactions, although there was also much complaint of interference in the administration of justice. All these symptoms and warnings, however, had no effect on Rome. The Curia continued to act as if the Decalogue had been intended to serve as a source of revenue for Rome. Its venality and behead robbers, why should we allow this Roman miser, who is the greatest thief and robber that has ever appeared or ever will appear on earth, to go free? . . . There is in Rome a constant buying, selling, exchanging, bartering, intoxication, lying, deceiving, robbing, stealing, boasting, whoring and villainy. . . Venice, Antwerp and Cairo can in no way compete against this fair and traffic of Rome. . . . At last the pope has erected an exchange especially for all these noble commercial transactions, the Datorius House at Rome. Thither must come all those who act in this way in order to obtain fiefs and livings. . . If you have money in this exchange, then you can get everything, and not only that, but here all sorts of usury are considered honest money, and stealing goods is vindicated. . . Oh, what skinning and what exaction go on there; it is made known that all the laws of God are only made so that money can be amassed, money which must be had in order to be a Christian."

${ }^{10}$ LEA, loc. cit., p. $66 \%$. 
became proverbial. Even Æneas Sylvius, before he became pope, had no scruple, as Mr. Lea informs us, in asserting that everything was for sale in Rome, and that nothing was to be had there without money. The most popular books of the time, like the Stultifera Navis of Brandt and the Schelmenzunft of Thomas Murner, were savage attacks on Rome. Murner is never tired of dwelling on the scandals and exactions of the clergy from high to low, from bishop to monk. When the lord, he tells us, has shorn the sheep, the priest comes and fairly disembowels it. The invention of printing aided greatly in making the opposition to Rome European, in fusing local grievances into a general discontent and hostility. When Luther hung up his theses on the church door of Wittenberg, they were read and known a month later in every school and convent of Europe.

The Protestant revolt started in Germany because this country was politically weak and consequently the more exposed to Rome's rapacity. In France and Spain the kings were able to resist the demands of the Curia with some measure of success; in Germany the emperor had no corresponding power. "In $\mathbf{I}_{52} \mathrm{I}$ the papal nuncio Aleander writes that, five years before, he had mentioned to Pope Leo his dread of a German uprising; he had heard from many Germans that they were only waiting for some fool to open his mouth against Rome." 17

$$
{ }^{17} \text { LEA, loc. cit., p. } 690 .
$$


The financial exactions and venality of the Curia caused the Protestant revolt. That is Mr. Lea's explanation of the event. Here also we have an economic interpretation of history; but how different is the story from that told by Engels! ${ }^{18}$

Marxian socialism calls itself " scientific socialism" because of its economic interpretation of history. With the help of this method it claims to unveil to us the real story of the past; with the help of the same method it claims to reveal to us the future. Serious as are the difficulties which an analysis of the past

${ }^{18}$ Extraordinary is also Engels's economic interpretation of predestinarianism. Calvin's doctrine of predestination, Engels informs us, "was the religious expression of the fact that, in the conmercial world of competition, success or failure does not depend upon a man's activity or cleverness, but upon circumstances uncontrollable by him. It is not of him that willeth or of him that runneth, but of the mercy of unknown superior economic powers; and this was especially true at a period of economic revolution, when all old commercial routes and centers were replaced by new ones, when India and America were opened to the world, and when even the most sacred economic articles of faith-the value of gold and silver-began to totter and break down." ENGers, Socialism, Utopian and Scientific, pp. xxiii, xxiv. As a matter of fact, however, the doctrine of predestination antedates considerably Calvin's writings and Engels's commercial routes. Compare, for instance, Romans viii, 30: "And whom he foreordained, them he also called: and whom he called, them he also justified: and whom he justified, them he also glorified." Engels could find the whole doctrine of predestination in St. Augustine's De libero arbitrio, in the fourth century, or in Scotus Erigena's De predestinatione, in the ninth century, or in St. Thomas's Summa theologica, in the thirteenth century, to say nothing of the writings of earlier religious thinkers. In defense of Engels's statement it might be urged 
at times presents, its data are certainly more tangible than the events of the future. Engels's story of the Protestant Reformation shows that his method does not automatically produce a scientific history of our past. Is it then reasonable to suppose that the same method insures infallibility when the future is concerned?

There is no necessary connection between the economic interpretation of history and socialism. A man may interpret the past in terms of economic cause and effect and yet be given to no speculations about

that the doctrine of predestination, however ancient its formulation, did not get its hold on the people before the comme:cial development of the sixteenth century, with its many bankruptcies, had prepared the popular mind for such a doctrire. It is true that predestinarianism did not become popular before the sixteenth century. But on the other hand it is not in commercial Venice and Genoa, but in countries very backward economically, that the doctrine first came into vogue, e.g., in Scotland and in New England. Here again Engels's interpretation fails to interpret. The spread of predestinarianism in the wake of the Protestant revolt seems to me easily comprehensible without any such forced explanations. The writings of the early churchmen, as we have seen, are full of predestinarianism. The mediæval Church, however, could not possibly make a basic doctrine of it, for the simple reason that, if men and women were predestined to be saved or damned, then all the pardons and absolutions which the Church might sell were of very doubtful value. One of Germany's distinguished theologians, Johan Rucherath of Wesel, who was a predestinarian, drew precisely these conclusions. Such conclusions interfered with the business of the Church, and he was compelled to recant in 1479 . The leaders of the Reformation, as we know, had a profound contempt for "works" as they saw them practised. It seemed unreasonable to Luther that salvation should depend upon the 
the future, or he may be led to forecast an increasing individualism. It would obviously be inadmissible to call such an one a socialist. Until recently, nevertheless, every writer who interpreted history economically was taken and declared to be an orthodox disciple of socialism. This was no chance error, but rather a well-defined type of a mode of classification in which the popular mind habitually indulges. The popular mind, it is well to remember, does not dwell with the philosophers in their " marble temple shining on a hill," but in the muddy world of concrete personal experiences. ${ }^{10}$ Systems of philosophy, or scraps of

"works" which he had such abundant opportunity to observe, and we see him turning to salvation by faith. Calvin, likewise detesting the "works" of the Romanists, took another road of opposition-predestinarianism. The doctrine of salvation by faith and the doctrine of election alike emphasized the opposition of the reformers to the purely technical character of the "works" required by Rome. Interesting are Dr. Bush's observations on the practical reasons which led two such contrasting centuries as that of Augustine and Calvin to determinism. "If a large part of the system of ideas known as Augustinian was invented in the fifth century to prove the necessity to man of the official ministrations of the Church, it was adapted in the sixteenth and seventeenth centuries to prove the futility of those ministrations. How should the sacraments play any part in a man's salvation if this is a matter decided by the direct election of God? How should some words spoken by a priest control the action of grace? For precisely opposite reasons to those which influenced Augustine, the Augustinian determinism became a dogma of the Reformation; in the one case determinism to prove the necessity of sacraments, in the other to prove the futility of sacraments." WENDELL T. Bush, "Sub specie æternitatis," in The Journal of Philosophy, Psychology and Scientific Methods, vol. iv (1907), p. $660 . \quad{ }^{10}$ William James, Pragmatism (1907), pp. 2I, 22. 
them, act upon the mind of the public only after they have become part and parcel of that tangle of experiences through which it has to find its way. In assorting and classifying theories the popular mind is guided not by logic but by experience. It perceives that certain theories, philosophical and literary, are set forth and defended by persons who hold certain social or political views; and by a process which may be described as "substitutional" it identifies the theories with the tendencies which they foster and subserve. Thus in Russia, for decades, the writers who defended "art for art's sake" were immediately recognized as political reactionaries, while every "realist" was assumed to be a liberal or a radical. Similarly in Germany, during the first half of the nineteenth century, " romanticism" stood for political conservatism, if not for reaction, while in Feuerbach's decade " naturalism" stood for political revolution and a humanitarian socialism. Similarly Marx's economic interpretation of history has come to stand for militant socialism.

Logically, such substitutions were and are indefensible. The connection between these theories and the practical ends which they were used to subserve was local or temporary. In England, for example, William Blake, who was certainly neither realistic nor naturalistic, who shared with German romanticists and Russian devotees of art for art's sake the love of the symbolic and mystic, inclined in his political theories 
to revolutionary socialism. ${ }^{20}$ In England, "art for art's sake" was preached by William Morris, a socialist, and by Oscar Wilde, who saw in man's first disobedience man's original virtue, advocated the abolition of property, urged taking rather than begging, marked down all our values and considered our society to be bankrupt. Similarly, the economic interpretation of history has been divorced from socialism. Today, as Professor Seligman points out, "the writers who are . . making the most successful application of the economic interpretation are not socialists at all." 21

In their place and time, however, these popular classifications were accurate. The Russian literary men of the sixties who advocated art for art's sake represented a religious and political authoritarianism. On the other hand, the faithful description of the actual conditions of existence in Russia which the realists called for and supplied meant propaganda, primarily of discontent, ultimately of revolution. The German romanticists were conservatives or reactionaries; and Feuerbachian naturalism, according to Feuerbach himself, was intended to prepare the way for the recon-

30 Cf. William Blake, Poetical Works (Rossetti's ed., i890), p. 142. Regarding Blake as a "Liberty boy" and his attitude towards the Revolution, cf. Edwin J. Ellis, The Real Blake (London, 1907), pp. 162 et seq.

${ }^{21}$ Seligman, The Economic Interpretation of History (1902), p. 109. 
struction of the political and social order. ${ }^{22}$ Similarly, the popular identification of the economic interpretation of history with socialism represented a correct appreciation of Marx's motives and of the practical bearing of the method as employed by him and his disciples.

It was for political reasons that Marx emigrated to France; it was for similar reasons that he was exiled from France; in Brussels he lived under the constant and suspicious supervision of the Belgian " administration of public safety." Is it to be assumed that he gave so much concern to the several governments because he was busily engaged in elaborating a scholarly method for historical research? Or is it to be assumed that a year after the hunger riots of the Silesian weavers, a year or two before the revolution of ' 48 , he was taking a rest from all political activity, escaping the turmoil by giving himself up to the joys of pure theory?

Far from it. We see Marx and Engels speculating; but the axes upon which their speculations revolve are the social movement and the political revolution. Their literary activity is their political activity. ${ }^{23}$ The economic interpretation was not the offspring of dis-

22 Ludwig Feuerbach, Werke (Leipzig, i846), I, pp. xiv, xv.

28 ". . . It is hence quite evident how important a place the desire to do practical work above all else held in this literary plan on which Marx and Engels had for a long time been intent." Aus dem literarischen Nachlass von Marx, Engels, etc. (Stuttgart, 1902), II, p. 332. 
passionate research; it was conceived in minds saturated with ideas of social revolution. As early as 1845, at the Elberfeld gathering of communists, Engels, still a half-utopian so far as the future organization of society was concerned, argued for communism as an economic necessity and pictured the social revolution as economically unavoidable. "With the same certainty," Engels tells us, " with which from a given mathematical proposition a new one is deduced, with the same certainty we can deduce the social revolution from the existing social conditions and the principles of political economy." 24 Two years later Marx and Engels were writing the Communist Manifesto, the "fundamental proposition" of which is the economic interpretation of history.

The propaganda of the economic interpretation of history, of the "critical insight into the conditions, progress and general results of the actual social movement," ${ }^{25}$ was Marx's chief activity during the years $1846-1848$, and this activity was political. He was not conducting a historical seminar in Brussels; he was supplying the revolutionary army with a new revelation and was instilling into it a spirit of absolute confidence in the triumph of its cause. It was the future that concerned him; the past was a pièce justificative. An interpretation of history he called it, be-

"Rheinische Jahrbücher zur gesellschaftlichen Reform, herausgegeben von Hermann Pütmann, vol. i (Darmstadt, 1845), pp. $78,79$.

"MARX, Herr Vogt (London, 1860), p. 35. 
cause to him, born as he was in the Hegelian school, past, present and future were one historical process.

It was Marx's economic interpretation of history, and not that of any other man, which attracted public attention; and in classifying the economic interpreters of history as socialists, the popular mind exhibited, as in other similar cases, a perfectly sound appreciation of both the psychological motive and the practical aim of the theory. But this classification also has proved to be temporary. To-day, such is the irony of fate, the economic interpretation of history, while of great value to the historical student, is an unyielding and merciless steel trap in which so-called scientific socialism is caught and held. 


\section{CHAPTER IV}

CONCERNING CONCENTRATION OF PRODUCTION IN INDUSTRY AND AGRICULTURE

The socialistic state of Marx was not to be manufactured by any world-reformer. Socialism was to be a product of economic tendencies, and of these the most important was the concentration of production.

Any one who is acquainted with the thought of the nineteenth century knows that the industrial changes that were in progress were very generally viewed with misgivings if not with apprehension. In the first half of the century, i.e., at the time when the doctrines of scientific socialism were formulated, the tall chimney, to use Schultze-Gaevernitz's expression, ${ }^{1}$ was generally regarded as a warning finger-a mene tekel of impending revolution. The social effects of the introduction of machinery were too serious to be overlooked. The tendency towards industrial centralization and the social, economic and political aspects of this tendency were attracting the attention of many

${ }^{2}$ Schultze-Gaevernitz, The Cotton Trade in England and on the Continent (London, 1895 ), p. 164. 
thoughtful men before Marx began to speak or write. What was drastically formulated by Marx as an unavoidable necessity had been previously suggested and discussed as a possibility. Constantin Pecqueur, ${ }^{2}$ for example, had pointed out with remarkable clearness that the older methods of production could not compete with the modern factory, and that production on a large scale was so much cheaper that the centralization of industry was a matter of economic necessity. ${ }^{3}$ Pecqueur had also raised the question: If production on a large scale has undoubted advantages, what is likely to happen to the small establishments? and had answered that they would be wiped out by cruel competition, and that the small producers would possibly themselves become proletarians. Socially and politically such a situation would reduce itself to a new industrial feudalism. The sole alternative which he saw was a central-

'C. PecQueur, Économie sociale: Des intérêts du commerce, de l'industrie et de l'agriculture, et de la civilisation en général, sous linfluence des applications de la vapeur (2d ed., Paris, 1839). This work of Pecqueur was widely read and was crowned by the French Institute.

" "Every one knows that, in reality, in using steam to reduce the cost of products and realize great advantages, it is necessary to operate on a large scale, to use large amounts of capital and a large number of workmen; in a word, to produce on a large scale. . . O Otherwise there is no economy. The expense of the initial establishment and maintenance of two steam-engines of unequal power is not proportional to their degree of inequality. Thus an engine twice as powerful as another does not cost twice as much; it does not require two stokers instead of one, twice as much room, twice as much fuel, nor twice as much time to operate." C. Pecqueur, op. cit., I, pp. 56, 57. 
ized industry on democratic lines, based on copartnership and coöperation."

Whether Pecqueur influenced Marx is immaterial. The ideas expressed by the French economist were at the time more or less common property. Only the way in which Marx formulated them is important. For him it was not a question of a choice between industrial feudalism or industrial democracy. The present had but one road to travel; upon the future was the stamp of the inevitable. From his point of view there was no need to invent socialistic industrial schemes. Industry and agriculture would necessarily become thoroughly centralized and socialized. There would be no need to force the artisan, the small trader, the farmer into a socialistic scheme. "The small tradespeople, shopkeepers and retired tradesmen generally, the handicraftsmen and peasants-all these

- One may readily infer that joint stock companies or very rich individual capitalists and manufacturers will swallow up the work of the small producers, killing them off by competition which is immeasurably unequal and cruelly pitiless; it may happen that all who are neither capitalists nor landowners will, little by little, join the ranks of the proletarians. . . ." Ibid., I, pp. $396,397$.

"Either on the disappearance of small-scale production the small producers will be co-partners of the large concerns, aiding in production and participating in the profits, in accordance with their capacity, their capital and their work; or they will degenerate into paid workmen, into a herd of serfs working from day to day in factories; into proletarians, always poor, always without a future; and all the large industries will be exclusively monopolized by an industrial feudalism." Ibid., II, p. IOI. 
sink gradually into the proletariat," 5 and the centralization of industry goes on. Nor is that to be the fate of the lower middle class only. "Entire sections of the ruling classes are by the advance of industry precipitated into the proletariat." " To the question: Will socialism expropriate and abolish the hard-won private property of the small farmer? he responds: "There is no need to abolish that; the development of industry has to a great extent already destroyed it, and is still destroying it daily." $\tau$

Marxian socialism had profound contempt for utopias. Why should amateur schemes of an economic and social organization be elaborated, when capitalism's own mission was to organize and centralize the production of the commonwealth? No preaching of eternal justice can assemble scattered production, and there is no possibility of socialism without such economic centralization.

Sixty years have passed since Marx's Manifesto was published; it is therefore fair to inquire whether the economic changes that have occurred have justified his theories and expectations.

That a centralization of industry has taken place. is an undeniable fact. Moreover, this centralization has gone further in this country than anywhere else in the world. Professor Seligman writes: "Accord-

- Communist Manifesto (Kerr ed.), p. 2 I.

- Ibid., p. 26.

'Ibid., p. 34. 
ing to the census of 1900 there were 185 combinations, representing 2,040 plants and turning out products to the value of $\$ 1,667,350,000$, a little over 14 per cent of the total industrial output of the United States. But since 1900 the movement has progressed rapidly. In 1900 there were 16 combinations, each with a capital of over $\$ 50,000,000$ and with an aggregate capital of $\$ 1,231,000,000$. In 1907 . . . not only were there 27 such combinations with an aggregate capital three times as great $(\$ 3,785,000,000)$, but a single combination now had a larger capital than the I 6 combinations and about one-half as large as all the 185 combinations in 1900." 8 The combination to which Professor Seligman refers is the United States Steel Corporation, an industrial consolidation which controls not less than 785 industrial plants. While the United States is generally regarded as the land of trusts par excellence, the growth of large industrial consolidations and combinations is very much in evidence both in England and on the continent of Europe.

But the centralization of industry in recent years is by no means primarily due to purely technical conditions-to the development of the tool into the machine. Steam and machinery have certainly favored large-scale production, but there has been no such far-reaching centralization as the Marxian vision pf future economic development presaged. The cotton

- Seuigman. Principles of Economics (3d ed., 1907), p. 342. 
industry of Great Britain, the history of which furnished so much material to the author of Capital, exhibited, as Bernstein has pointed out, only a very moderate concentration in the twenty-odd years following the publication of Marx's work. Here is a comparison of the data for 1868 as given by Marx with the data for 1890 :

\begin{tabular}{c|r|r|r}
\hline \multicolumn{1}{c|}{ Cotron Industry } & \multicolumn{1}{|c|}{1868} & \multicolumn{1}{c|}{1890} & \multicolumn{1}{c}{ Percentage } \\
OF
\end{tabular}

The other branches of the textile industry show, according to Bernstein, even less concentration. ${ }^{\circ}$ In at least one branch of the textile industry, in weaving, the number of factories steadily increased: in 1870 they numbered 1,658 ; in $1874,1,703$; in $1878,1,765$; in $1885,1,915$; in $1890,2,015$. In the textile industry as a whole, the number of establishments fluctuated as follows: in 1870 there were 6,807 ; in 1874 , 7,394 ; in $1878,7,105$; in $1885,7,465$; in 1890 , $7,190 .{ }^{10}$

- Bernstern, Die Voraussetzungen des Socialismus und die Aufgaben der Sozialdemokratie (Stuttgart, 1899), p. 56.

10 These data are taken from the Statistical Abstract for the United Kingdom (London, 1897), pp. 202, 203. 
The development of the trust, therefore, can scarcely be regarded as the inevitable result of industrial technique. It is rather to be viewed as a counterrevolution against free competition. Free competition led persistently towards lower prices, overproduction and lower profits; the desire to check the ruinous results of free competition has led to trade agreements, pools, syndicates, combinations-to one form or another of what we call the trust. "After all," writes Macrosty, "men are in business not to exhibit the ' natural' laws of economics but to make an income, and it is a poor consolation to a bankrupt to know that he has been overwhelmed by a stream of tendency." 11

Experience has further shown that trusts do not necessarily wipe out smaller concerns. In our everyday language we class as trusts not only giant mergers and rigid industrial consolidations, but all sorts of industrial trade agreements, federations, pools, syndicates and associations formed for the purpose of maintaining prices. The looser federations are especially characteristic of Europe's industrial development. So Macrosty sums up the tendency in the English iron industry by expecting " in no very remote future to see the iron industry governed by loose federations of great powers, each large firm

${ }^{11}$ Macrosty, Trusts and the State (I90I), p. I52. 
belonging to a number of associations according to the variety of its products." 12

As a matter of fact, pools and trade associations often help to maintain smaller industrial organizations. E. J. Smith, the promoter of the "Birmingham Alliances," has laid special stress on the protecting of the smaller concerns, saying: "The great advantage which a large capital gives must be retained as legitimate interest on capital only, instead of being given away for the purpose of flooding the markets with productions at selling-prices which cannot be charged by less fortunate firms without loss. Materials used in the process of manufacture have their fair average market values, which most makers have to pay. The purchasing of large quantities of material at one time, and to be paid for promptly, will no doubt make the buyingprices lower to the lucky capitalist, but whatever advantage is gained in this way should be regarded as interest on capital and retained." 13

The more one studies the trusts, the less one is inclined to make sweeping generalizations. The types of combinations are so numerous and the policies of the individual combinations are so varied that only one general statement can be made with confidence, namely, that all trusts tend to organize to a greater or

${ }^{12}$ MACROSTY, The Trust Movement in British Industry (1907), p. 330 .

${ }^{13}$ E. J. Smith, The New Trade Combination Movement (1899), p. 27 . 
less degree their respective industries and to maintain steadier prices.

The social democrats of both continents, however, see in the American trust movement proof positive of the inerrancy of the Marxian forecast of economic development. Certain European socialist pamphlets convey the impression that the American manufacturing industry is thoroughly concentrated and organized, that the smaller producer is practically eliminated, and that the trusts are tending toward a trust of trusts. America therefore, at least technically and economically, is far ahead of all other countries on its way towards organized, centralized, socialized production.

In studying the report on "Manufactures" of the Twelfth Census, one is impressed by the number of small and middle-size industrial establishments of which the report takes cognizance. Here are the figures for 512,254 industrial establishments: ${ }^{14}$

\begin{tabular}{|c|c|c|c|c|c|}
\hline No employees, & 110,510 & $5 I$ to & 100 & employees, & II,663 \\
\hline Under 5 “ & 232,726 & IOI to & 250 & “ & 8,49 \\
\hline 5 to 20 " & 112,138 & 251 to & 500 & “ & 2,8 \\
\hline to 50 “" & $\begin{array}{l}32,408 \\
\text { Over } 1,00\end{array}$ & & & “ & \\
\hline
\end{tabular}

The special census report of 1905 on "Manufactures" gives us a comparative table which shows, on the whole, a gradual tendency towards concentration, with the small producer in many industries holding his own.

"Twelfth United States Census (1900), "Manufactures," part i, p. lxxiii. 
Indeed, the number of industrial establishments increased from 1890 to 1900 more rapidly than the number of wage-earners. ${ }^{15}$

\begin{tabular}{lrrc} 
& \multicolumn{1}{c}{1890} & \multicolumn{1}{c}{1900} & $\begin{array}{c}\text { INCREASE } \\
\text { (PERCENTAG) }\end{array}$ \\
Number of establishments, & 355,415 & 512,254 & 44.1 \\
Number of wage-earners, & $4,251,613$ & $5,308,406$ & 24.9
\end{tabular}

Of course it is a fact that certain industries are centralized and organized on a national scale and are practically monopolies. Such facts present serious problems. But we are more likely to find an advantageous solution of such problems by dealing with the facts as they are than by dealing with unverifiable "future" facts.

The industry of Europe is much more scattered and decentralized than that of the United States. According to the last German census, 4,770,669 out of about ten million wage-earners were employed in petty commercial and industrial establishments with one to five employees each. ${ }^{16}$ In that country the independent artisans are far from being eliminated by the industrial process. In Prussia, in I861, there were 534,556 masters and 558,321 apprentices; in 19001902 the independent masters numbered 679,323, with $559,73^{8}$ journeymen (Gesellen) and 253,055 appren-

${ }^{15}$ Special Census Report, "Manufactures," 1905, part i, p. xxxvi.

${ }^{10}$ Sombart, Sozialismus und soziale Bewegung (6te Auflage, Jena, 1908), p. 84 . 
tices (Lehrlinge). ${ }^{17}$ In commerce the small establishment is still more persistent than in industry. The German Empire counted: ${ }^{18}$

\begin{tabular}{|c|c|c|}
\hline COMMERCIAL ESTABLISHMENTS & 1882 & 1895 \\
\hline 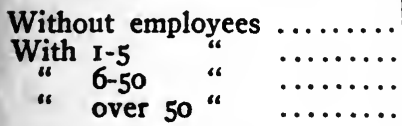 & $\begin{array}{r}429,825 \\
246,413 \\
26,531 \\
463\end{array}$ & $\begin{array}{r}454,540 \\
450,913 \\
49,271 \\
960\end{array}$ \\
\hline
\end{tabular}

Such is the state of concentration in German industry and commerce. Let us now consider the Marxian doctrine and the facts regarding concentration in agriculture.

The attitude of Marx and of Engels towards the agricultural population was consistently unfriendly. In their first great work the fathers of scientific socialism praise capitalism for rescuing " a considerable part of the population from the idiocy of rural life." 10 In the second part of the third volume of Capital Engels expresses the hope that the virgin soil of the Russian steppes and American prairies may still ruin Europe's landlords and peasantry. ${ }^{20}$ The reason for this attitude is obvious. On the one hand socialist production is technically impossible unless scattered agriculture "J. Wernicke, Kapitalismus und Mittelstandspolitik (Jena, 1907), p. 134.

"Ibid., p. 240.

10 MarX and Engers, The Communist Manifesto, p. 19.

20 "Fortunately by no means all prairie land is as yet under cultivation; there still remains enough on hand to ruin all the great European landlords, and the small ones in addition." Marx, Das Kapital (Hamburg, 1894), vol. iii, part ii, p. 260. 
is concentrated; on the other hand the socialistic propaganda encounters in the peasant proprietor its most conservative and most obstinate foe, against whose will no social reconstruction of society is conceivable. In a discussion of the situation in France, Engels admits that no social revolution is possible without the backing of the peasants. ${ }^{21}$

The Marxian theory of course declares that small farming, like every petty industry, is doomed. This we learn from the Communist Manifesto; and the same information is given in the later writings of Marx and Engels and in those of their official commentators. Thus we read in Capital: "In the sphere of agriculture, modern industry has a more revolutionary effect than elsewhere, for this reason, that it annihilates the peasant, that bulwark of the old society, and replaces him by the wage laborer. Thus the desire for social changes and the class antagonisms are brought to the same level in the country as in the towns." ${ }^{22}$ In Der Vorbote, the party organ of the International, Marx's ardent follower, Johann Philipp Becker, declared, in large print, soon after the appearance of Capital, that the omnipotence of capital, the influence of science, the tendencies of the times and the interest of society as a whole had irrevocably and

21 "In one respect our French associates are absolutely correct; in France no lasting revolution against the small farmers is possible." Fr. Encers, "Die Bauernfrage in Frankreich und Deutschland," Die neue Zeit, I895, I, p. 30I.

${ }^{22}$ MarX, Capital (fourth English ed., London, 1891), I, p. 513. 
mercilessly condemned small-scale agriculture to slow but inevitable death. ${ }^{23}$ This attitude was characteristic of the whole Marxian wing of the International. It was entirely in keeping with the Marxian doctrine, which may be summed up in the equation: small farming stands in the same relation to centralized agriculture as the hand-loom to the power-loom in industry. ${ }^{24}$

The attitude of Marxism towards the land question did not change with the passing of the International. We find the same doctrine, and even the same wording of the doctrine, in Liebknecht's Grund- und Bodenfrage, which for years served as a catechism for socialist agitation among the German peasantry. The central assertion of this booklet is that the small agriculturist is doomed..$^{25}$ The doctrine is set forth to-day

"Der Vorbote, December, I869, p. I8I.

"J. Georg Eccarius, Eines Arbeiters Widerlegung der nationökonomischen Lehren John Stuart Mills (Hottingen-Zurich, I888), p. 52. This booklet of Eccarius was revised by Marx and is consequently an authorized expression of his views. On page 57 of the same pamphlet one reads: "Farming on a small scale is politically, socially and economically doomed. It has nowhere fulfilled expectations and will nowhere keep pace with modern industry and social progress. It is the fifth wheel on the wagon, impeding political and social progress, the leaden weight which has paralyzed labor agitation in France and elsewhere on the Continent.".

"W. LIEBKNECHT, Die Grund- und Bidenfrage (Leipzig, Verlag der Genossenschaftsbuchdruckerei, 1874). The pamphlet ends (p. 128) with the words: "In short the steam plow will revolutionize agriculture in the same way as the steam loom and the spinning jenny have already revolutionized industry,by destroying production on a small scale." The important fact is not that the booklet was in great vogue but that its posi- 
in every Marxian social-democratic program. The program of the German Social Democratic party begins with the well-known sentence: "The economic development of bourgeois society leads by natural necessity to the downfall of the small industry, whose foundation is formed by the worker's private ownership of his means of production. It separates the worker from his means of production and converts him into a propertyless proletarian, while the means of production become the monopoly of a relatively tion was strictly Marxian. The critic of Marx may truly observe that here is a doctrine which had no basis of fact whatsoever and no shadow of justification. But the greater was the faith with which this theory was received. The experiences of 1848 were fresh in men's memories, and the alternative suggested by the outcome of the French disturbances was that either the social revolution or the peasant was doomed. The socialists chose the latter interpretation. Liebknecht frankly explains: "We need the peasant and the small farmer if our struggle is not to be a hopeless one. The fatal opposition between city and country which has so far hindered and frustrated every movement in the direction of freedom must cease. The warning example of France is not lost upon us. On the 24th of February, I848, Paris, the city, overthrew the throne of the corrupt citizen king, and nine weeks later the country sent to Paris a reactionary National Assembly which undermined the newly founded republic, and organized the insurrection of June, which was to overthrow the social-democratic, industrial proletariat. Five and a half months after the battle of June the country, by an overwhelming majority, chose Louis Bonaparte as president of the republic, and thereby prepared the way for the coup d'état which three years later put an end to the republic, and delivered France over to the systematic plundering of the Bonapartist robbers. The country is what the peasants make it. The French peasantry created an empire through their blind fear of proletarian socialism." Ibid., p. 103. 
small number of capitalists and large landowners." The capitalist and the large landowner are thus put into one class, and small industry, whether industrial or agricultural, into another class, predestined to be destroyed.

Let us turn now to the leading contemporary exponent of orthodox Marxism, the official interpreter of the German party program, Karl Kautsky. He also admits that it is useless to try to make socialists out of real peasants. "Peasants who feel that they are not proletarians but true peasants, are not only not to be won over to our cause but belong to our most dangerous adversaries." 28 Economic tendencies, however, are wiping them out of existence. To promise any succor to the small-scale producer in industry or in agriculture is to feed him on illusions. Efforts to arrest the inevitable economic development will be fruitless; if they produce any results at all, these results will be injurious to the classes in whose behalf the efforts are made. Painful as the process may be, the peasant is bound to sink into the proletariat. ${ }^{27}$

Naturally enough this theory has aroused little en-

30 Karr Kautsky, "Das Erfurter Programm und die Landagitation," Die neue Zeit, 1895, I, p. 280.

"It is not social democracy that is responsible for the economic development. Without its assistance the capitalist class sees to it that business on a small scale shall give way to business on a large scale, nor has social democracy any reason to oppose such a development. One who opposes the economic development is not by any means a true representative of the real interest of the small farmer and small producer of the city, 
thusiasm in the agricultural districts; and neither in France nor in Germany have the socialists made any headway among the peasants. Realization of this fact has caused attempts to be made, both in France and in Germany, to make the socialist program more attractive to this class. The French Socialist Congress which met at Nantes, in September, 1894, and the German Social Democratic Convention (Parteitag) held at Frankfort, in October of the same year, adopted resolutions favoring protection of peasant interests. At the Frankfort Convention Dr. Schönlank suggested that a different "lingo" be used in talking to the peasant. Socialistic doctrine should be administered to him in homeopathic doses,-otherwise, this speaker feared, the medicine might kill the patient. ${ }^{28}$

Such proposals and efforts are easily explicable

for all attempts in that direction will inevitably prove futile, and in so far as they have any effect, will be injurious rather than beneficial. To hold out to the artisans and peasants a mode of action by which their small business can be made profitable is in no way to intercede for their interests; it is rather awakening in them illusions which can never be realized and which divert them from the right way of best protecting their interests." KarL KaUtSky, Das Erfurter Programm in seinem grundsätzlichen Theil erläutert (2d ed., Stuttgart, 1892), p. 254.

28 "Though in this way we succeed in doing nothing more than neutralizing the effects of this peasantry, we have done enough. . . . 1848 must not repeat itself. When absolutism had reached its fruition the reaction promptly made concessions to the peasants and so won them over. We must be on our guard lest the hobnailed shoes of the peasants sons be raised against us; we must neutralize and pacify them. (Applause.) With the country people we must talk plainly in their own jargon. We must at last urge a practical agitation, not merely a gray 
from the opportunist point of view of the popular agitator, but they are not in harmony with the Marxian doctrine. The contradiction between that doctrine and the peasant program of the Frankfort and Nantes Conventions was so glaring, that Kautsky expressed the situation quite accurately by saying that, while the socialists were still very far from capturing the peasants, the peasants had captured the socialists. ${ }^{29}$ No less distinct was Engels's protest. To a French socialist, who was seeking his instruction and advice, he explained that the progress of capitalism was destroying peasant property absolutely; that there was no reason why the party should not endeavor to make the proletarization of the peasantry less painful; but that to go further and to try to save the peasantry was to attempt the economically impossible, to sacrifice the principle, to become reactionary. ${ }^{30}$ Of the same tenor was the last article of Engels in the Neue Zeit, already quoted. Large-scale production, he said, would run down the peasantry with their small farms theory. . . . Our revolutionary politics cannot consist of highsounding phrases. . . . The socialistic medicine must be administered to the country people in homeopathic doses, otherwise it will kill the peasants." Protokoll über die Verhandlungen des Parteitages der sozialdemokratischen Partei Deutschlands, abgehalten zu Frankfurt am Main, 1894, p. 141.

20 "There is only one clear cause for this severe political relapse, and that is regard for the peasants. We have not as yet captured them, but they have already captured us." Die neue Zeit, 1895, I, p. 28I.

- This letter is reprinted from the Vorwärts in the proceedings of the Frankfort Convention, p. I5I. 
just as a railroad train would run down a wheelbarrow. $^{31}$ How strongly Engels felt on the subject is further shown by some of his recently published letters to the American socialist, Sorge. In one of these he characterizes the effort to win the peasants as a "confidence game" (Bauernfängerei), and declares that any attempt to protect them against taxes, usury and the great landholding interests is in the first place imbecile and secondly impossible. ${ }^{32}$ His feelings were bound to be shared by every one who understood the Marxian doctrine and was a "scientific" socialist. Some of the leading German socialists, like Schippel, did not hesitate to designate the socialist agrarian program as a bit of political charlatanism. ${ }^{33}$ And the Frankfort Convention of 1895 dis-

"ENGers, "Die Bauernfrage in Frankreich und Deutschland," Die neue Zeit, 1895, I, p. 303.

82 "On the continent the desire for further success grows with success, and the ensnaring of the peasantry in the literal sense is becoming the fashion. First the French in Nantes announce through Lafargue not only (as I have written you) that we are not called upon by our own direct interference to hasten the ruin of the small peasantry to which capitalism is committed, but, secondly, that we ought directly to protect the peasant against the taxes, usury, and the large landholding interests. That, however, we cannot undertake, for in the first place it is stupid and in the second place it is impossible." Briefe und Auszïge aus Briefen von Johann Philipp Becker, Josef Dietzgen, Friedrich Engels, Karl Marx u. A. an F. A. Sorge und Andere (Stuttgart, 1906), p. 415.

"s "The agrarian program which suddenly endeavors to meet the peasant movement is a piece of this political charlatanism." Protokoll über die Verhandlungen des Parteitages su Breslau, 1895, p. 110. 
avowed most emphatically the agrarian program, because it promised to the peasantry the improvement of their conditions, which meant the strengthening of their property rights. ${ }^{34}$

The Convention of Frankfort adjourned; the German Social Democracy rested upon its reaffirmation of the Marxian doctrines, including the inevitable doom of the peasantry; but, by one of fate's little ironies, a census (the first since 1882 ) had been taken at the beginning of that very year, and while the discussions in Frankfort were in progress the statistical results of this census were being computed. To the Marxian theorists the results were staggering. The small agricultural landholder was gaining ground. The doctrine of concentration of agriculture was disproved. The census showed that each hundred hectares of land under cultivation was divided among the following groups in the following proportions:

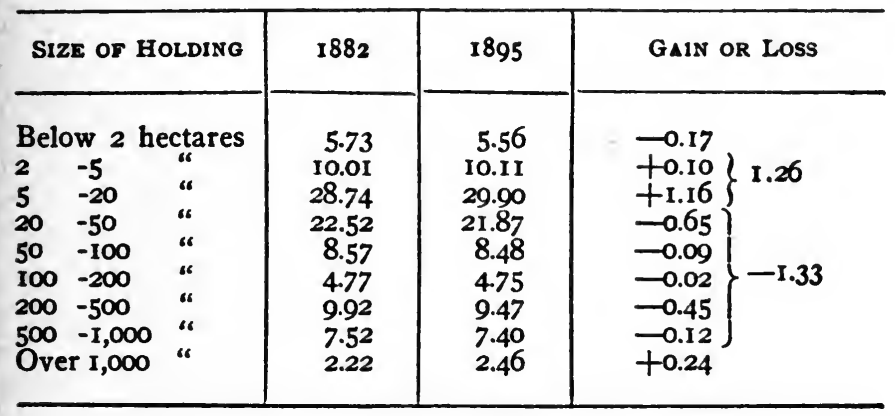

"s "The agrarian program submitted to the agrarian commission should be rejected, for it places before the peasantry 
In words instead of figures, this table means that the middle-sized farms ( 20 hectares = nearly 50 acres) which can be taken care of by a peasant family without the help of wage labor are on the increase. ${ }^{35}$ These data have impressed all unprejudiced economists as showing that the farmer who depends upon his family has a distinct advantage over the landowner who has to depend upon hired farmhands. The farms ranging from two to twenty hectares have gained in thirteen years not less than 659,259 hectares, while those ranging from twenty to one thousand hectares have actually lost 86,809 hectares.

The statistical data of other countries yield more or less the same results. No theory of concentration of agriculture or of the doom of the small farmer can be based, for example, on the figures given by our United States census reports: ${ }^{36}$

the prospect of an improvement in their position, as well as the strengthening of their private property rights." Ibid., p. 204.

${ }^{8}$ Interesting in this respect are the conclusions drawn from the data of the German census by Professor Rauch berg in his article on "Entwicklungstendenzen der deutschen Volkswirtschaft" in Archiv für soziale Gesetzgebung und Statistik (IgOI), XII, pp. 339 et seq. For a short digest of the census material relating to agriculture, see DR. G. von MAYR's Allgemeines statistisches Archiv (1898), V, pp. 658-675.

"Abstract of the Twelfth Census of the United States, 1900 (Washington, 1902), p. 217. 


\begin{tabular}{c|c|c|c}
\hline YEAR & $\begin{array}{c}\text { NUMBER OF } \\
\text { FARMS }\end{array}$ & $\begin{array}{c}\text { NUMBER OF } \\
\text { ACRES }\end{array}$ & $\begin{array}{c}\text { AVERAGE NUMBER } \\
\text { OF ACRES TO } \\
\text { A FARM }\end{array}$ \\
\hline & & & \\
1900 & $5,737,372$ & $838,591,774$ & 146.2 \\
1890 & $4,564,641$ & $623,218,619$ & 136.5 \\
1880 & $4,008,907$ & $536,081,835$ & 133.7 \\
1870 & $2,659,985$ & $407,735,041$ & 153.3 \\
1860 & $2,044,077$ & $407,212,538$ & 199.2 \\
1850 & $1,449,073$ & $293,560,614$ & 202.6 \\
\hline
\end{tabular}

In America the average acreage is still too large for intensive cultivation, and with increasing land values we may confidently expect a very considerable decentralization. ${ }^{37}$ For Holland, Bernstein ${ }^{38}$ quotes the following data:

\begin{tabular}{|c|c|c|c|c|}
\hline \multirow{2}{*}{$\begin{array}{l}\text { SIZE OF FARMS } \\
\text { (IN HECTARES) }\end{array}$} & \multicolumn{2}{|c|}{ NUMBER OF FARMS } & \multirow{2}{*}{$\begin{array}{l}\text { INCREASE OR } \\
\text { DECREASE }\end{array}$} & \multirow{2}{*}{ Percentage } \\
\hline & I 884 & I 893 & & \\
\hline $\begin{array}{l}1 \quad-5 \\
5-10 \\
\text { IO-50 } \\
\text { Over } 50\end{array}$ & $\begin{array}{r}66,842 \\
31,552 \\
48,278 \\
3,554\end{array}$ & $\begin{array}{r}77,767 \\
94,199 \\
51,940 \\
3,510\end{array}$ & $\begin{array}{r}+10,925 \\
+62,647 \\
+\quad 3,662 \\
-\quad 44\end{array}$ & $\begin{array}{l}+16 \\
+198.5 \\
+\quad 7.6 \\
+\quad 1.2\end{array}$ \\
\hline
\end{tabular}

In Friedrich Hertz's instructive book a large amount of statistical material is to be found, all showing the

"7 "Land values tend to rise with growing prosperity. A given capital thus represents a constantly diminishing acreage, and it becomes increasingly profitable to apply more labor and minor machines to small areas rather than large capital and vast machines to great areas. That is, we have a tendency to more intensive rather than large-scale farming." Seligman, Principles of Economics, p. 336.

" Bernstein, Voraussetzungen des Sozialismws, p. 62. 
non-existence of any tendency towards centralization of agriculture. ${ }^{39}$

Eduard David, the well-known socialist leader, who is unquestionably the most learned socialist authority on all agricultural questions, has come to the conclusion that the peasants are getting the better of the large landowners ${ }^{40}$ and that their standard of life is rising rapidly, the agricultural life of to-day being a life of great comfort as compared with that of the preceding generation. ${ }^{41}$ David, of course, is not an orthodox Marxian, but a "revisionist."

We see accordingly, that while concentration in industry and commerce is far from complete centralization, no tendency towards concentration exists in agriculture.

Marxian socialism, as has been sufficiently shown, is not the scheme of would-be world-reformers. Socialism is to be the inevitable result of certain conditions and tendencies. It is to be the heir of capitalism. It will step into its heritage when capitalism has developed a centralized and socialized mode of production and has created a thoroughly proletarized, class-conscious and revolutionary population. For this reason the figures and facts above presented are

${ }^{89}$ F. O. HERTz, Die agrarischen Fragen im Verhältniss zum Sozialismus (Wien, r899). See also Shippel's estimate of Hertz's book, "Hertz gegen Kautsky," Sozialistische Monatshefte, 1899, pp. 507-510.

"DAvid, Sosialismus und Landwirtschaft (Berlin, I903), I, pp. 50, 5 I. 
of vital significance to scientific socialism. If certain conditions and tendencies make socialism inevitable, do not the absence of these conditions and the existence of contrary tendencies make socialism impossible? True to the letter and true to the spirit of the Marxian doctrine was Kautsky when he wrote: "So long as the artisan feels himself to be an artisan, the peasant a peasant, the small trader a small trader, so long as they possess a strong class-consciousness, they must, no matter how ill they fare, steadfastly adhere to private ownership of the means of production and remain inaccessible to socialism." 42

" Karl Kautsky, Das Erfurter Programm in seinem grundsätzlichen Theil erläutert (2d ed., Stuttgart, 1892), p. 180. 


\section{CHAPTER V}

\section{CONCERNING THE DISAPPEARANCE OF THE MIDDLE CLASS}

THE centralization of production in industry and agriculture has, according to Marx, a political side: it proletarizes the masses. The economic development, therefore, not only paves the way technically for socialist production but also produces the political force that is to put an end to capitalism. Or, as Marx expresses himself: "Not only has the bourgeoisie forged the weapons that bring death to itself, it has also called into existence the men who are to wield those weapons, the modern working class, the proletarians." 1

We have seen in the preceding pages that so far as agriculture is concerned there is, if anything, a slight decentralization of production. Consequently the proletarization of the farming class may be dismissed from consideration. In industry the situation is different. Here concentration has taken place, and it is claimed that the masses have been correspondingly or more than correspondingly proletarized. Let us try to find out, therefore, exactly what is meant by "proletariat" and "proletarization of the masses."

${ }^{1}$ Communist Manifesto, p. 22. 
Marx tells us that " in proportion as the bourgeoisie, i.e., capital, is developed, in the same proportion is the proletariat, the modern working class, developed-a class of laborers who live only so long as they find work, and who find work only so long as their labor increases capital." 2 The official interpreter of presentday orthodox Marxism, Karl Kautsky, explains to us wherein the factory hands of to-day differ not only from the artisan and farmer of the past, who owned the means of production and were therefore independent, but also from the journeymen of the pre-capitalistic epoch. The latter, he says, "belonged to the family of the master, with the expectation of becoming some day masters themselves. The proletarian stands entirely on his own feet and is doomed to remain forever a proletarian." 3

This Marxian conception of the proletarian as a modern product involves an idealization of the past. As a matter of fact, the little we actually know about the conditions which prevailed in mediæval industry gives us no intimation of a golden age, but rather a record of woe and distress. In making this statement I do not refer simply to the period of the so-called decay of the guild system, when the masters, as we are told, were primarily bent on exploiting the journeymen and keeping them out of the guilds; on the contrary, I include the entire epoch in which the guilds flourished. I see no necessity for differentiating this

Ibid.

' KaUtsky, Das Erfurter Programm, pp. 33, 34. 
epoch into historical periods, because I can find no fundamental points of difference. We all know that as early as the thirteenth and fourteenth centuries there were bitter struggles between the journeymen and the masters. The master blacksmiths of Frankfort, first organized as a guild in 1377 , entered in 1383 into an ironclad agreement with the guilds of Worms, Speyer, Mainz, Bingen and four or five other German cities to keep their journeymen under control and in submission." The same situation existed in other parts of Germany and in other European countries. In Danzig, for instance, the beginning of the struggle between masters and journeymen followed immediately upon the organization of the guilds. In 1385 the journeymen were striking and the city authorities were threatening to cut off their ears. ${ }^{5}$ In France, the "family relations" of masters and journeymen were characterized by strikes and riots, leading to bloodshed. ${ }^{\circ}$ In Rheims, as early as 1292 , the masters were

- Cf. Schanz, Gesellenverbände, p. 42.

- Kulisher, Evolucia pribili s kapitala (1906), I, pp. 419, 420; also Schönlank's article "Gesellenverbände" in the fourth volume of ConRAD's Handwörterbuch für die Staatswissenschaften.

- "The history of the towns of Brie and Champagne is full of internal crises which remind one of the strikes and riots of modern times. In I280 the journeymen drapers of Provins, furious at the increase in their hours of work, rose in revolt and murdered the mayor. At Châlons what occurred was not of such a tragic nature; however, the king had to intervene with letters patent to compel the workmen to work morning and afternoon." Étienne Martin-Saint-LÉn, Histoire des corporations de métiers (Paris, I897), p. 280. 
enjoined from combining against their journeymen, and the latter from conspiring against their masters. ${ }^{7}$ Nor does England show any lack of evidence that its journeymen regarded themselves as a separate class, antagonistic to the masters. As early as 1350 and 1362 London ordinances were adopted to put an end to journeymen's strikes. ${ }^{8}$ Not only do we find in fourteenth-century England a special journeyman class, composed of workmen who have little hope of ever becoming masters, who are confronted with prohibitive entrance fees for admission into the mystery, but in some trades the masters have gone so far as to exact an oath from apprentices that they will not set up in business for themselves, even if they can, unless their masters shall give thereto their special consent. We see the legislature and town council trying to intervene in favor of the journeymen. As Pro-

\section{Ibid.}

- "Whereas, heretofore, if there was any dispute between a master in the trade and his man (vadlett), such man has been wont to go to all the men within the city of the same trade, and then, by covin and conspiracy between them made, they would order that no one among them should work or serve his own master, until the said master and his servant or man had come to an agreement; by reason whereof the masters in the said trade have been in great trouble, and the people left unserved; it is ordained, that from henceforth, if there be any dispute moved between any master and his man in the trade, such dispute shall be settled by the wardens of the trade." W. J. AsHLEY, Introduction to English Economic History and Theory (New York, I893), II, p. 104. 
fessor Ashley justly observes, " the evil must have been unendurable before the town council would interfere; for in most places the mysteries were so powerful that the municipal authorities were only too ready to support the master-craftsmen. ${ }^{\circ}$

Marx was not unaware of the difference between mediæval masters and journeymen when he was developing, in the opening lines of his Manifesto, his doctrine of class-struggle; but whenever he discussed the city proletariat as a product of modern capitalism, totally and fundamentally differing from any working class in the past, he ignored the extent to which those journeymen were a class.

In some degree, however, Marx's failure to distinguish between masters and journeymen in the Middle Ages is justifiable. The difference in economic wellbeing between the so-called independent master, the possessor of the so-called "means of production," and his dependent hired men was slight. We have the English laws and regulations concerning wages from 25 Edward III (I350). These regulations fixed the maximum wage for laborers and artificers. The employer who should pay, as well as the artisan who should demand and receive, higher wages than those enacted, were to be fined and severely punished. The schedules of wages were revised and changed by successive legislatures, and they therefore afford an in-

$$
\text { -Ibid., p. } 105 .
$$


sight into the actual economic conditions and standard of living of those independent producers of the Middle Ages who appeal so strongly to our imagination. From the Statute of Laborers we learn that the artisans were to be sworn twice a year to observe the regulations. Their wages were settled in 1350 in the following proportion: ${ }^{10}$

\section{From Easter to Michaelmas, without Diet}

A master carpenter by the day.................. 3d

A master free mason by the day............... $4 d$

Other carpenters by the day................... $2 d$

Other masons by the day...................... $3 d$

Their servants by the day.................... $1 \frac{1 / 2 d}{2}$

Tilers by the day........................... $3 d$

Their knaves by the day..................... $11 / 2 d$

Other coverers of fern and straw by the day......... $3 d$

Their knaves by the day.................... $11 / 2 d$

Plasterers and other workers of mud-walls by the day. $3 d$

Their knaves by the day.................. $11 / 2 d$

The purchasing power of these wages is indicated by the allowance made for food, i.e., by the difference in the wages of artisans with and without diet. For the following century, when wages were somewhat higher, we have wage lists showing this difference, and the cost of food per day for one man or woman is taken to be from three half-pennies to two pence,

10 Cf. Sir Frederick Morton Eden, The State of the Poor, or an History of the Laboring Classes in England (London, 1797), I, p. 33. "In I 360 the Statute of Laborers was confirmed by Parliament, and the observance of it enforced under penalty of imprisonment for fifteen days and burning in the forehead with an iron in the form of the letter F." Ibid., p. 36 . 
usually two pence. Here is the wage list of the year r 496, with and without diet: ${ }^{11}$

\author{
From Easter From Michaelmas \\ to Michaelmas to Easter
}

A free mason

A master carpenter

A rough mason

A bricklayer

A master tiler

A plumber

A glazier

A carver

A joiner

Other laborers (except in $\}$ with diet $2 d$ with diet $11 / 2 d$ harvest)

Master carpenters and masons having under them six men

$\int$ without diet $4 d$ without diet $3 d$

with diet $\quad 4 d \quad$ with diet $3 d$ without diet $6 d$ without diet $5 d$ with diet $5 d$ without diet $7 d$

\title{
In Harvest
}

Every mower by the day with diet $4 d$, without $6 d$ A reaper " " $3 d$, " $5 d$ A carter " " $3 d$, " $5 d$ A woman and other laborers " $2 \frac{1}{2} d$, " $4 \frac{1}{2} d d$

The master, we observe, when employed, is allowed three times the cost of his own food for the feeding of himself, wife and family, housing, clothing and other necessities-a standard of life to which the proletarian of to-day has no cause to look back with envy or regret.

The wages in other trades are similar.

${ }^{11}$ Ibid., p. 75 . 


\section{With meat Without meat and drink and drink}

A master ship-carpenter having charge of the work and having
men under him

$5 d$

$4 d$

$3 d$

$3 d$

$4 d$

$3 d$

$4 d$
$7 d$

$6 d$

$5 d$

$5 d$

$6 d$

$5 d$

\section{Another mean caulker} A caulker laboring by the tide, for
every tide

From Michaelmas to Candlemas the wages of these artificers are to be $I d$ a day less.

Wages gradually increased, but it is doubtful if they increased more rapidly than the cost of living. Sir George Nicholls gives us the following table:

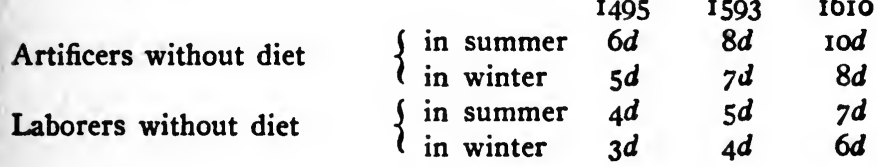

His comment upon these figures is: "On the whole, then, it may, I think, be assumed that at the end of Elizabeth's reign, notwithstanding the increase which had taken place in the price of all commodities, the great mass of the English people were able, by a due exercise of industry, to obtain as large an amount of subsistence and physical enjoyment as at any former period." 12

${ }^{22}$ Sir George Nicholls, $A$ History of the English Poor Law in connection with the State of the Country and the Condition 
The alleged welfare of the laboring class of the past as compared with our proletariat of to-day may therefore be seriously questioned. But in the course of centuries certain relations and regulations had worked themselves out, which insured at least the bare existence of the master and of the laboring man. The industrial revolution brushed aside all the old regulations, substituting for them "industrial liberty." The modern proletariat is a legitimate child of this industrial liberty, which for a few decades seriously aggravated the conditions of the laboring population. The industrial transformation, the centralization of scattered industry, and the resultant concentration of workingmen in large cities tended to consolidate this laboring population into a class and added greatly to its political significance.

The dynamic conception of society and its structure - the conviction that no type of social order is permanent and immutable, that the social order is subject to change and rational improvement-this conception, foreign to the modern world before the eighteenth century and the French Revolution, opened new vistas and possibilities to the laboring men as well as to their masters. They were allies without distinction in their struggle, in the name of democracy, against the old feudal order. But very soon the hopes and prophecies of democracy were differentiated. The interpretations

of the People (new edition, New York, 1898), vol. i, pp. 204-225. See also pp. 79-8I, 100, 10I, 135, 155, 269-27I and 356. 
put upon the word varied so greatly that those differing in its interpretation began to regard each other as belonging to a dangerous and undesirable class. Is it not natural that men who are tied during the long day to a machine in the factory, and who sleep in dingy tenements, should look forward to something better; that men who have so little else should have a wealth of hope?

In their visions the laboring masses of to-day certainly differ from the plebs misera of past centuries. Their aspirations stamp them as a modern product. They hope for industrial democracy, and this hope is based on a reasonable expectation that the political efforts of enfranchised citizens will result in ultimate success. The industrial proletariat of to-day is therefore not so much a new economic entity as a new politico-psychological element in our body politic. ${ }^{18}$ If the sole characteristic of an industrial pro-

"It is almost incredible that a man like Sombart, who made a reputation as an exponent of the proletarian movement and its theory, should in his recent booklet give the following characterization of the proletarian: "Der Proletarier weiss ebenso wenig von einer Dorf- und Geschlechtergemeinschaft wie von einer Familiengemeinschaft, ebenso wenig von einer Berufsgemeinschaft wie von einer Arbeitsgemeinschaft. Er ist vereinzelt, vereinsamt, mit seinen Genossen nicht enger verbunden als das einzelne Sandkorn mit dem andern im grossen Sandhaufen. Wie ein vom Baum gewehtes Blatt das der Wind über die Fluren treibt." Werner Sombart, Das Proletariat: Bilder und Studien, p. 14. If this were true, there would be no proletarian movement. In an earlier book Sombart gave us a more sensible description of the psychological makeup of the proletariat: "In 
letariat were poverty, there would be nothing new in the proletariat of to-day. The poverty in merry England was appalling, but England was merry; we are told that in one reign 70,000 paupers and vagabonds were executed, but we are not told that it made any political impression. It is not uninteresting to note that two of the ablest Russian statesmen of the time of Nicholas I, Count Kisseleff and Count Cancrin, argued in favor of agricultural poverty as compared with industrial wealth, because of fear of the political significance of an industrial proletariat. ${ }^{14}$ Recent history has proved that, from their point of view, they were right. Not the starving

the tenement houses, the huge manufactories, the public houses for meetings and for pleasures, the individual proletarian, as if forsaken by God and man, finds himself with his companions in misery again together, as members of a new and gigantic organism. Here are new societies forming, and the new communities bear the communistic stamp, because of modern methods of work. And they develop, grow, establish themselves in the mass of men, in proportion as the charm of separate existence fades from the individual; the more dreary the attic room in the suburb of the city, the more attractive is the new social center in which the outcast finds himself again treated as a man. The individual disappears, the companion emerges. A uniform class consciousness matures itself, also the habit of communal work and pleasure. So much for the psychology of the proletariat." Sombart, Socialism and the Social Movement of the Nineteenith Century, translated by Anson P. Atterbury (Chicago, 1902), pp. 14, 15.

10 [CANCRIN], Die Oekonomie der menschlichen Gesellschaften und das Finanzwesen, von einem ehemaligen Finanzminister (Stuttgart, i845), pp. 59, 60. Cf. Zablocki-Dessyatkovski, Count Kisseleff and His Times (St. Petersburg, I882), II, p. 199. 
millions of peasantry but the comparatively small industrial proletariat has precipitated and carried on the Russian revolution.

In gathering scattered production modern industry has gathered and united the scattered workers; and in so far as these men work and live under the same conditions and have the same interests they are bound to develop a comradeship and fellow-feeling which could not flourish in the same degree in the past. In this sense it is quite true that with the advent of modern industry a new economic and political element, the industrial proletariat, has made its appearance. The significance of the proletariat as a class will be discussed later. For the moment we are occupied with the Marxian view of the "proletarization of the masses."

In 1847, when German industry was in its beginnings, Marx informed us, in his Manifesto, that the proletariat class formed the great majority of the people. "All previous historical movements," he wrote, "were movements of minorities, or in the interest of minorities. The proletarian movement is the selfconscious, independent movement of the immense majority, in the interest of the immense majority." 15 What is meant here by the "proletariat"? Simply poor people? Not to-day only, but throughout the historic period of our society, the poor people have constituted the overwhelming majority. But that

$$
{ }^{13} \text { Communist Manifesto, p. } 30 .
$$


could scarcely encourage Marx. What reason had he to suppose that in the future this majority would feel and act otherwise than it had felt and acted in the past ? ${ }^{16}$

Marx fully realized that poverty as such creates no radical or revolutionary class. The defeat of the socialist projects of the Paris proletariat and the election of a Louis Bonaparte were ascribed by Marx himself to the poor French peasantry. ${ }^{17}$ The Lumpenproletariat, also the pauper and dependent class, Marx himself excluded from the proletarian army, and for good reasons: "The social scum, that passively rotting mass thrown off by the lowest layers of an old society, may, here and there, be swept into the movement by a proletarian revolution; its conditions of life, however, prepare it far more for the part of a bribed tool of re-

${ }^{10}$ That the majority is but a beast of burden in spite of its apparent power, Marx's seventeenth-century forerunner, Campanella, had said in a sonnet worth quoting: "The people is a fat and motley beast, ignorant of its own prowess and hence enduring burdens, lash and cudgel. Driven it is by a feeble child, whom it could shake off in an instant. But it fears that child, and so it serves all its whims and fancies, never realizing how much it itself is feared by that very child. . . . Marvelous thing! They hang themselves with their own hands and send themselves to jail and bring upon themselves war and death for a single farthing, paid to them out of the many that they themselves have given to the king. Everything between heaven and earth belongs to them, but they do not know it, and should any one tell them that, they would knock that man down and kill him." Tommaso Campanella, Opere, scelte da Alessandro Ancona (Torino, 1854), p. 79.

${ }^{17}$ Marx, The Eighteenth Brumaire of Louis Bonaparte, translated by Daniel De Leon (New York, I8g8), p. 7 I. 
actionary intrigue." 18 It is obvious, therefore, that Marx, in talking about the proletariat, has in mind men and women employed in capitalistic industry.

Now in 1895, nearly half a century after the Manifesto was published, the number of men and women employed in all capitalistic enterprises, in industry, commerce and transportation, was, according to Sombart's calculation, based on the German census, 3,921,571. Deducting from this number the employees of an obviously non-proletarian grade, managers, superintendents, higher employees, officials, etc., he estimates that the rest number about three and one-half millions, or about thirteen to fourteen per cent of the population. ${ }^{10}$ Accordingly, even now, a movement that should include the whole of the industrial proletariat would still be far from being a movement of the "immense majority."

But we are told that the masses are rapidly being proletarized, that the middle class is rapidly sinking in the proletariat. "As we have already seen," so ran the statement of the Manifesto, "entire sections of the ruling classes are, by the advance of industry, precipitated into the proletariat, or are at least threatened in their conditions of existence. These also supply the proletariat with fresh elements of enlightenment and progress." 20 What makes socialism inevita-

18 The Communist Manifesto, p. 29.

10 Sombart, Das Proletariat, p. 5.

${ }^{20}$ The Communist Manifesto, p. 28. 
ble, Engels tells us, is on the one hand the concentration of capital in the possession of a few and on the other hand the concentration of the propertyless masses in the large cities. ${ }^{21}$ Here is the core of Marxian socialism. Not only is the middle class gradually being wiped out, but the lesser capitalists are gradually being reduced to proletarian existences, swallowed up by the greater capitalists. Thus the capitalistic band becomes smaller and smaller, while the army of the proletariat grows by thousands and by millions. And while capital is thus being concentrated in few hands, industry becomes more and more socialized on a national, even international basis. A socialized mode of production is then already in existence, and all that remains for the complete establishment of a socialist commonwealth is the expropriation of the few capitalists by the mass of the people. Socialized production is transformed by a simple political act into socialized property. But, on so important a point, let Marx speak for himself: "As soon as this process of transformation has sufficiently decomposed the old society from top to bottom, as soon as the laborers are turned into proletarians and their means of labor into capital, as soon as the capitalist mode of production stands on its own feet, then the further socialization of labor and further transformation of the land and other means of production into socially exploited and there-

2 ENGELs, Landmarks of Scientific Socialism (Anti-Duehring), translated by A. Lewis (Chicago, 1907), p. 179. 
fore common means of production, as well as the further expropriation of private proprietors, takes a new form. That which is now to be expropriated is no longer the laborer working for himself, but the capitalist exploiting many laborers. This expropriation is accomplished by the action of the immanent lazes of capitalistic production itself, by the centralization of capital. One capitalist alway's kills many. ${ }^{22}$ Hand in hand with this centralization, or this expropriation of many capitalists by few, develop, on an ever-extending scale, the coöperative form of the labor-process, the conscious technical application of science, the methodical cultivation of the soil, the transformation of the instruments of labor into instruments of labor only usable in common, the economizing of all means of production by their use as the means of production of combined, socialized labor, the entanglement of all peoples in the net of the worldmarket, and with this, the international character of the capitalist régime. Along with the constantly diminishing number of the magnates of capital, ${ }^{23}$ who usurp and monopolize all advantages of this process of transformation, grows the mass of misery, oppression, slavery, degradation, exploitation; but with this too grows the revolt of the working class, a class always increasing in numbers and disciplined, united, organized by the very mechanism of the process of capitalist production itself. The monopoly of capital becomes a

${ }^{22}$ Italics are mine.

"Italics mine. 
fetter upon the mode of production which has sprung up and flourished along with and under it. Centralization of the means of production and socialization of labor at last reach a point where they become incompatible with their capitalist integument. This integument is burst asunder. The knell of capitalistic private property sounds. The expropriators are expropriated. . . The transformation of scattered private property, arising from individual labor, into capitalistic private property is, naturally, a process incomparably more protracted, violent and difficult than the transformation of capitalistic private property, already practically resting on socialized production, into socialized property. In the former case, we had the expropriation of the mass of the people by a few usurpers; in the latter, we have the expropriation of a few usurpers by the mass of the people." 24

If Marx has correctly formulated the economic tendency, if capital tends invariably towards concentration in the hands of a narrowing circle of magnates while the rest of the population is rapidly being proletarized, it is really marvelous that a social revolution has not yet overtaken this iniquitous system, to which practically the whole of the people must be opposed. If the capitalist class, which alone has any real interest in the protection of property, is rapidly dimin-

"4 Marx, Capital (English translation, 4th ed., London, I89I), I, pp. 788,789 . 
DISAPPEARANCE OF THE MIDDLE CLASS 87

ishing; if the future has nothing in store for the selfrespecting middle class but misery and degradation; then indeed it takes no prophet to foretell that the title of the few magnates to their wealth is not worth the paper on which it is written. Then indeed are the days of the present economic organization numbered; and Bebel was quite right when, in addressing his party convention in $189 \mathrm{I}$, he declared: "Yes, I am convinced that the realization of our ultimate aims is so near that there are but few in this hall who will not live to see that day." 25

Let us, however, test the abstract proposition by the facts. Let us take, for example, the Prussian income statistics. The Prussian statistics, as we all know, are relatively the most accurate in existence. ${ }^{26}$ In Prussia we have data of a graduated income tax for over half a century, coinciding with the period of the most rapid industrial transformation. These data, it is obvious, are especially valuable for our purpose.

"Protokoll über die Verhandlungen des Parteitages der socialdemokratischen Partei Deutschlands, abgehalten zu Erfurt, 1891, p. 172.

${ }^{30}$ All the figures given below are taken from the two monographs of Adolph Wagner, published in the Zeitschrift des Königlich Preussischen Statistischen Bureau (Berlin, 1904), vol. xliv, pp. 41-122; and 229-267: "Zur Methodik der Statistik des Volkseinkommens und Volksvermögens, mit besonderer Berücksichtigung der Steuerstatistik" and "Weitere statistische Untersuchungen über die Verteilung des Volkseinkommens in Preussen auf Grund der neuern Einkommensteuerstatistik (1892-1902)." 
From the point of view of income the German population is usually divided into three groups: a lower class, a middle class and an upper class. Each of these three classes is subdivided into three strata: a lower, a middle and an upper. They represent the following individual yearly incomes:

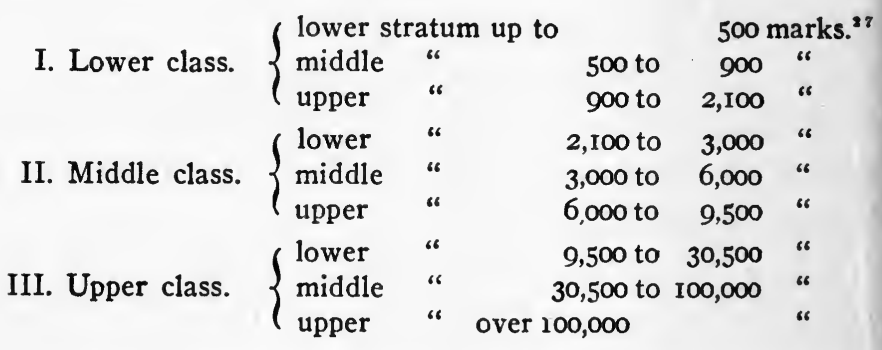

The following table shows, at ten periods during the fifty years $1853-1902$, the absolute number of persons in the upper stratum of the lower class and the lower stratum of the middle class, and the absolute number and percentage of persons in the middle and upper strata of the middle class and in the upper class. All the figures given in the first three columns are thousands (ooo omitted).

${ }^{27}$ Incomes below 500 marks are now extremely rare in Germany; they represent as a rule the lower agricultural laboring class. In the 500-900-marks group belong the poor peasantry and the poorly-paid workingmen. The 900-2, I0o-marks group includes clerks and salesmen, skilled workingmen, younger officials, public school teachers, well-to-do peasants, artisans and petty store- and saloon-keepers. Specially skilled mechanics are often found in the lower stratum of the middle-class group with incomes of 2,100-3,000 marks. 
DISAPPEARANCE OF THE MIDDLE CLASS 89

\begin{tabular}{|c|c|c|c|c|}
\hline \multirow{2}{*}{ YEAR } & \multirow{2}{*}{ POPULATION } & \multicolumn{2}{|c|}{$\begin{array}{c}\text { NUMBER TAXED ON } \\
\text { INCOMES }\end{array}$} & \multirow{2}{*}{$\begin{array}{l}\text { PERCENTAGE } \\
\text { TAXED ON } \\
\text { INCOMES OVER } \\
\text { 3000 MARKS }\end{array}$} \\
\hline & & $\begin{array}{l}900 \text { TO } 3000 \\
\text { MARKS }\end{array}$ & $\begin{array}{c}\text { OVER } 3,000 \\
\text { MARKS }\end{array}$ & \\
\hline $\begin{array}{l}1853 \ldots \ldots \ldots \\
1867 \ldots \ldots \ldots \\
1870 \ldots \ldots \ldots \\
1873 \ldots \ldots \ldots \\
1878 \ldots \ldots \ldots \\
1882 \ldots \ldots \ldots \\
1891 \ldots \ldots \ldots \\
1892 \ldots \ldots \ldots \\
1896 \ldots \ldots \ldots \\
1902 \ldots \ldots \ldots\end{array}$ & $\begin{array}{l}16,870 \\
19,157 \\
23,909 \\
24,644 \\
25,748 \\
26,820 \\
29,456 \\
29,895 \\
31,349 \\
35,551\end{array}$ & $\begin{array}{r}825 \\
963 \\
1,319 \\
1,370 \\
1,356 \\
1,304 \\
1,743 \\
2,119 \\
2,321 \\
3,310\end{array}$ & $\begin{array}{r}44.4 \\
72.9 \\
106.4 \\
123.3 \\
167.3 \\
162.6 \\
254.3 \\
316.9 \\
331.1 \\
449.7\end{array}$ & $\begin{array}{l}0.263 \\
0.380 \\
0.445 \\
0.500 \\
0.650 \\
0.683 \\
0.863 \\
1.060 \\
1.057 \\
1.301\end{array}$ \\
\hline
\end{tabular}

The absolute number of middle- and upper-class taxpayers in the same years are given in the following table. The figures in the first column are thousands.

\begin{tabular}{|c|c|c|c|c|c|c|}
\hline \multirow{2}{*}{ YEAR } & \multicolumn{4}{|c|}{ Middle Class Incomes } & \multicolumn{2}{|c|}{$\begin{array}{l}\text { UPPER CLASS } \\
\text { INCOMES }\end{array}$} \\
\hline & $\begin{array}{c}2 \times 00 \text { TO } \\
3000\end{array}$ & $\begin{array}{l}3000 \text { TO } \\
6000\end{array}$ & $\begin{array}{c}6000 \text { To } \\
9500\end{array}$ & $\begin{array}{c}9500 \text { TO } \\
30,500\end{array}$ & $\begin{array}{c}30,500 \text { TO } \\
100,000\end{array}$ & $\begin{array}{l}\text { OVER } \\
100, \infty 00\end{array}$ \\
\hline 1853 & 46.9 & 32,003 & 7,239 & 4,463 & 640 & 62 \\
\hline $1867 \ldots .$. & 81.1 & 50,966 & 12,224 & 8,211 & 1,348 & 144 \\
\hline $1870 \ldots$. & 112.4 & 75,851 & 17,434 & I I,027 & I,9I I & 199 \\
\hline $1873 \ldots$. & 119.6 & 85,603 & 20,813 & 13,650 & 2,815 & 423 \\
\hline 1878. & 153.5 & 121,071 & 25,350 & 17,457 & 3,054 & 375 \\
\hline 1882 & 150.0 & 131,310 & 27,958 & 19,580 & 3,403 & 434 \\
\hline I891.. & 185.1 & I 80,862 & 38,275 & 28,776 & 5,442 & 915 \\
\hline 1892. & 223.4 & 204,544 & 55,561 & 46,092 & 9,034 & 1,658 \\
\hline $1896 \ldots$. & 260.1 & 214,960 & 57,859 & 47,308 & 9,265 & 1,699 \\
\hline $1902 \ldots .$. & 321.3 & $29 \mathrm{I}, 34 \mathrm{I}$ & 77,638 & 64,737 & 13,205 & 2,762 \\
\hline
\end{tabular}

We see from these figures how utterly unwarranted is the idea of the proletarization of the middle class. With all due allowance for the increased cost of living, we find the numberr of the well-to-do absolutely and 
relatively to the whole population on the increase. The same is true about the very rich.

The following little table gives the growth of the multimillionaire incomes in Prussia during the same period:

\begin{tabular}{|c|c|c|c|c|}
\hline \multirow{2}{*}{ YEAR } & \multicolumn{4}{|c|}{ INCOMES } \\
\hline & $\begin{array}{c}100,000 \text { TO } \\
500,000\end{array}$ & $\begin{array}{c}500,000 \text { TO } \\
x, 000,000\end{array}$ & $\begin{array}{c}1,000, \infty 00 \text { TO } \\
2, \infty 00, \infty 00\end{array}$ & $\begin{array}{c}\text { OVER } \\
2,000,000\end{array}$ \\
\hline 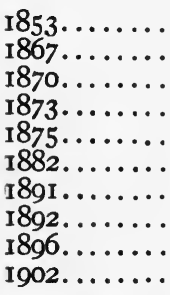 & $\begin{array}{r}60 \\
135 \\
187 \\
391 \\
399 \\
407 \\
859 \\
1,555 \\
1,596 \\
2,594\end{array}$ & $\begin{array}{r}2 \\
9 \\
12 \\
32 \\
18 \\
22 \\
43 \\
72 \\
76 \\
108\end{array}$ & $\begin{array}{r}4 \\
2 \\
8 \\
27 \\
20 \\
44\end{array}$ & $\begin{array}{r}4 \\
3 \\
5 \\
4 \\
7 \\
16\end{array}$ \\
\hline
\end{tabular}

Marx's formula " One capitalist always kills many," can hardly be regarded as a statement of fact. In I854 Berlin had only six men possessing over three million marks; in 1900 it had 639 in this class. In I854 there were in Berlin 23 men who possessed a million and a half each; in 1900 there were 1,323 in this group. And with all due respect to German honesty, it is well to remember that men are not likely to overestimate either their income or the value of their property when it comes to paying taxes.

The English income statistics present greater difficulties, owing to their arrangement in schedules, every taxpayer declaring his income on different 
schedules according to its character and source. If we take the incomes assessed under Schedule $D$, incomes from trades and professions, we find for the decade 1877-1886 the following changes:

\begin{tabular}{c|c|c|c}
\hline INCOMES & 1877 & 2886 & $\begin{array}{c}\text { PERCENTAGE } \\
\text { OF CHANGE }\end{array}$ \\
\hline $\begin{array}{r}\text { Between fi5o and } f 1,000 \ldots \\
\text { fr,000 and upwards......... }\end{array}$ & $\begin{array}{r}317,939 \\
22,848\end{array}$ & $\begin{array}{r}379,064 \\
22,298\end{array}$ & $\begin{array}{r}+19.26 \\
-2.40\end{array}$ \\
\hline
\end{tabular}

These figures led Goshen, then chancellor of the Exchequer, to enunciate the thesis of a decentralization of wealth. The period was one of depression, however. The data of tax assessments under Schedule D for the following decade do not show the same ultrademocratic tendency.

\begin{tabular}{|c|c|c|c|}
\hline INCOMES & 1888-89 & $1893-94$ & $\begin{array}{c}\text { Percentage of } \\
\text { Change }\end{array}$ \\
\hline 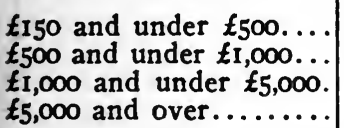 & $\begin{array}{r}347,520 \\
31,084 \\
18,665 \\
2,965\end{array}$ & $\begin{array}{r}362,048 \\
32,737 \\
20,431 \\
3,149\end{array}$ & $\begin{array}{l}+4.18 \\
+5.32 \\
+9.46 \\
+6.21\end{array}$ \\
\hline
\end{tabular}

\begin{tabular}{|c|c|c|c|}
\hline INCOMES 28 & $1894-95$ & $1897-98$ & $\begin{array}{l}\text { Percentage } \\
\text { Of Change }\end{array}$ \\
\hline 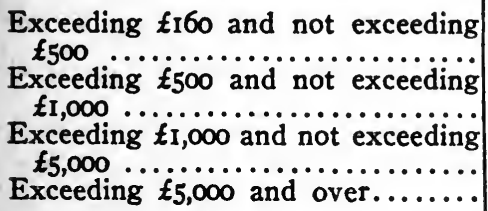 & $\begin{array}{r}278,370 \\
26,790 \\
17,146 \\
2,785\end{array}$ & $\begin{array}{r}306,200 \\
27,779 \\
18,113 \\
3,141\end{array}$ & $\begin{array}{l}+10.00 \\
+3.69 \\
+5.64 \\
+2.78\end{array}$ \\
\hline
\end{tabular}

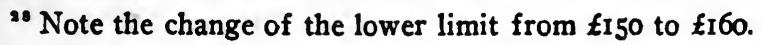


These fluctuations of incomes from trades and professions under Schedule D do not substantiate Goshen's premature thesis of the decrease of great wealth, but they undoubtedly indicate a steady growth of the middle class. It must be borne in mind that these figures do not include the incomes of the taxpayers as shareholders of companies, whose profits are assessed in the lump. And the army of stockholders presents a steady and enormous growth. In I887 Goshen wrote: "I have examined the figures of twelve companies, taken entirely at random-an insurance company, a water-works company, an industrial company, and so forth, and I have compared their capital and the number of shareholders ten years ago with the capital and the number of shareholders at present. Here is the result: the total paid-up capital of the twelve companies in 1876 was $\mathfrak{f}_{5}, 17 \mathrm{r}, 649$; in 1886 it had become $£ 6,501,582$, an increase of 25 per cent. But the shareholders in them had increased during the same ten years from II,667 to 20,083 , an increase of 72 per cent." 28

Here we come to a point which Marx has obviously overlooked: the economic significance of the jointstock company. The assumption that centralization of industry signifies centralization of ownership and capital is false. The opposite is the economic tendency; and this fact is acknowledged by such enlightened and

20 Viscount Goshen, Essays and Addresses on Economic Questions (London, 1905), pp. 231, 232. 
scholarly socialists as Eduard Bernstein. ${ }^{30}$ In England, in recent years, numbers of smaller firms have. been merged in larger stock companies. On April I, 1904, there were 37,287 such stock companies registered in England, many of these companies representing consolidations of a number of industrial or commercial firms, but the organization as joint-stock companies meant a wider distribution of both income and ownership. Here is an example:

\begin{tabular}{|c|c|c|c|c|}
\hline NAME OF COMPANY & $\underset{\text { TION }}{\text { CAPATALIZ. }}$ & $\begin{array}{c}\text { STOCKS } \\
\text { RETAINED BY } \\
\text { THE VENDORS }\end{array}$ & $\begin{array}{l}\text { NUMBER } \\
\text { OF FIRMS } \\
\text { AMALGA } \\
\text { MATED }\end{array}$ & $\begin{array}{l}\text { NUMBER } \\
\text { OF } \\
\text { STOCK- } \\
\text { HOLDER }\end{array}$ \\
\hline \multirow{5}{*}{$\begin{array}{l}\text { Fine Cotton Spinners } \\
\text { Bradford Coal Dyers. } \\
\text { Bradford Coal Mer- } \\
\text { chants ............ } \\
\text { A b e rd e e n Comb } \\
\text { Works ............ } \\
\text { Cooper, Cooper and } \\
\text { Johnson ............... }\end{array}$} & $\begin{array}{r}f_{4}, 000,000 \\
3,000,000\end{array}$ & $\begin{array}{r}f 1,333,350 \\
1,000,000\end{array}$ & $\begin{array}{l}31 \\
22\end{array}$ & $\begin{array}{l}3,934 \\
10,731\end{array}$ \\
\hline & 199,790 & I19,790 & 8 & 237 \\
\hline & 300,000 & 133,333 & 3 & 677 \\
\hline & 340,000 & 70,000 & 3 & 2,082 \\
\hline & $£ 7,839,790$ & $£ 2,656,473$ & 67 & 17,661 \\
\hline
\end{tabular}

Instead of 67 firms, 17,66I stockholders. True, about one-third of stock, probably sufficient to insure the control of the enterprises, was retained by the original firms, but the remaining two-thirds were distributed. The members of the original 67 firms have probably

"O Eduard Bernstein, Die heutige Einkommensberwegung und die Aufgabe der Volkswirtschaft (Berlin, 1902). See especially chapter iii (pp. 24-32) on "Die Conzentrierung der Unternehmungen und die Dezentralisierung der Eigentumstitel." 
become employees of the five new companies; but the change in their position is hardly to be viewed as a case of " proletarization," since, in addition to their salaries as company employees, they are receiving dividends on two and a half millions' worth of stock. The above example is characteristic of the whole recent industrial development. In five English brewing concerns we find that the stock is held by 27,052 persons. " Thomas Lipton," the grocery trust, has 74,262 shareholders; "Spiers and Pond" in London has 4,650 stockholders, and of these but 550 hold more than $\mathfrak{f}_{500}$ worth of stock.

The development of stock companies explains why the number of moderate incomes from trades and professions, taxed under Schedule $\mathrm{D}$, has not recently increased as rapidly as in the seventies and eighties. A large number of small tradesmen formerly assessed under Schedule D are now assessed as employees of public companies under Schedule E. ${ }^{31}$ If we exclude from this schedule the eighty-odd thousand army, navy and civil-service employees, we find that the number of employees of corporate bodies and of public companies increased more than one hundred per cent in fifteen years. The figures are:

$$
\begin{array}{lll}
1888-89 \ldots 130,862 & 1894-95 \ldots 155,752^{82} & 1898-99 \ldots 223.391 \\
1893-94 \ldots 166,161 & 1897-98 \ldots 187,240 & 1902-03 \ldots 272,500
\end{array}
$$

"Goshen, op. cit., p. 249.

32 This decrease is due to the raising of the exemption limit from $f I 50$ to $f r 60$. 
The same rapid growth of the army of stockholders is to be found in the United States. Some of our principal railroads, for example, show the following increases in the numbers of shareholders during the last four years:

\begin{tabular}{|c|c|c|}
\hline & 1904 & 1908 \\
\hline Pennsylvania & 42,100 & 59,600 \\
\hline Atchison....... & 17,800 & 25,000 \\
\hline New York Central & II,700 & 22,000 \\
\hline Union Pacific ...... & 14,200 & 15,000 \\
\hline Southern Pacific & 4,400 & 15,000 \\
\hline Great Western .. & 5,900 & 10,000 \\
\hline Erie $\ldots . \ldots \ldots \ldots \ldots \ldots$ & 4,300 & 10,000 \\
\hline Delaware and Hudson & 3,800 & 5,800 \\
\hline Norfolk and Western & 2,900 & 4,500 \\
\hline Chesapeake and Ohio & 1,500 & 2,600 \\
\hline
\end{tabular}

The American railroads count to-day about half a million stockholders as against 350,000 five years ago. The same decentralizing tendency is discernible in our industrial companies. The United States Steel Corporation counts to-day about I Io,000 stockholders; the Bell Telephone, 24,100; American Sugar, 20,000; Amalgamated Copper, 18,000; Pullman, 13,000. The total number of American shareholders is now estimated to be about $2,000,000$.

Thus, wherever we look, we find a steady increase of the middle class. In 1851 there were in England about 300,000 persons with an income of $\sum_{150-1,000 \text {, }}$ in $\mathrm{r} 88 \mathrm{I}$, about 990,000 . While the population during that period increased in the ratio of 27.35 , the English middle class increased in the ratio of 27.90 , i.e., 233 
per cent. In 1898 Bernstein estimated the number of middle-class taxpayers at a million and a half. ${ }^{33}$ Not only has the middle class, whose extermination is so essential to the triumph of socialism, greatly increased, ${ }^{34}$ but so have the numbers of co-partners of the great capitalistic enterprises-the army of stockholders, enlisted in the defense of capital and of vested interests. $^{35}$

It has been argued that Marx's analysis of our capitalist system was based on the assumption of free competition and failed to take into account the economic effects of corporate methods of business, and that, if competition were unchecked and there were no joint-stock companies, the concentration of capital in the hands of the few and the proletarization of the middle class would be unavoidable. Possibly this is

33 Bernstein, Die Voraussetzungen des Sozialismus und die Aufgaben der Sozialdemokratie (Stuttgart, 1899), p. 49.

34 "Now as a matter of fact, what is the income-tendency of the wealthy? As far as statistics on the subject are available, they show in every civilized country an extension rather than a shrinking of the rich classes." BERNSTEIN, Die heutige Einkommenbervegung ( 1902 ), p. $2 \mathrm{I}$.

ss "The army of stockholders constitutes to-day in every respect, politically and socially, the bulwark of capital. What would the handful of magnates be without the number, mounting into the hundred thousands, of middle-class and small stockholders? What could they do against public opinion? Nothing! The first storm would break their resistance. But together with the magnates of the second, fourth and eighth class, they form or sway what is known as public opinion." Bernstern, Die heutige Socialdemokratie in Theorie und Praxis (München, I906), p. 32. 
true; but it is not particularly useful to consider how different things would be if things had been different. The fact remains that the economic development has taken a turn which Marx did not foresee; and Karl Kautsky remained a true exponent of orthodox Marxism, when he exclaimed, at the Stuttgart Socialist Convention: "Yes, if that is true, then not only is the day of our victory ever to be postponed, but we can never reach our aim. If capitalists are on the increase and not the propertyless, then the development is setting us back further and further from our goal, then capitalism intrenches itself and not socialism, then our hopes will never materialize!" 36

"Protokoll über die Verhandlungen des Parteitages der sozialdemokratischen Partei Deutschlands, abgehalten zu Stuttgart, 1898 , p. 128. 


\section{CHAPTER VI}

\section{THE THEORY OF INCREASING MISERY}

WE are told that with the general proletarization of the masses, with the concentration of capital and the numerical diminution of capitalist magnates, a parallel process takes place which makes the existing mode of production not only intolerable but untenable. It is the progressive impoverishment, the rapidly increasing misery, the economic sinking and physical degeneration of the proletariat which make a social revolution mandatory upon suffering humanity under pain of starvation. ${ }^{1}$ In the words of the Communist Manifesto: "The modern laborer, . . . instead of rising with the progress of industry, sinks deeper and deeper below the conditions of existence of his own class. He becomes a pauper, and pauperism develops more rapidly than population and wealth. And here it becomes evident that the bourgeoisie is unfit any longer to be the ruling class in society and to impose its conditions of existence upon society as an overriding law. It is unfit to rule, because it is incompetent to assure an existence to its slave within his slavery, because it cannot help letting him sink into such a state that it has to feed him instead of being

${ }^{2}$ Marx, Capital, p. 789 . 
fed by him. Society can no longer live under this bourgeoisie; in other words, its existence is no longer compatible with society." 2 This doctrine of increasing misery, which was later elaborated by Marx in his Capital, is based upon observations and facts of his time. These facts Marx interpreted theoretically in a brilliant way.

Behind this doctrine of increasing misery was an original theory of wages. It was not the "iron law" of wages, as some recent writers claim. ${ }^{3}$ There is nothing specifically socialistic about the iron law of wages. It is Ricardo's theory, to which Lassalle added the adjective iron, and which Marx for many excellent reasons contemptuously rejected. ${ }^{4}$ The iron law of wages, while an effective weapon in the hands of so great an agitator as Lassalle, gave as such no reasonable assurance that the end of the wage system was near. A generation ago wages represented the laborer's cost of living; a generation from now wages would, according to the iron law, still represent the laborer's cost of living. This theory gives no ground

'Communist Manifesto, p. 3r.

'So, for instance, Rossignor, Orthodox Socialism, pp. 9, 26, and W. H. Mallock, Socialism (The National Civic Federation, New York, n. d.), p. 10.

-Marx wrote to Bracke in 1875 : "Of the 'iron law of wages' nothing, as is well known, is Lassalle's own except the word 'iron' borrowed from Goethe's phrase, 'ewigen, ehernen, grossen Gesetzen.' The word 'iron' is a term whereby those of the true faith recognize each other. If, however, I take the law with Lassalle's stamp and therefore in his sense, then I must also take it with his proof. And what is that! As Lange pointed 
for assuming that the wage-earners of the future will necessarily oppose the wage system any more than the laborers of the past have opposed it. On the other hand, a doctrine that declares inevitable a progressively increasing misery of the working class gives reasonable assurance that the wage-earners will increasingly and progressively oppose the existing economic system.

Furthermore, the industrial revolution was followed by an era of progressive diminution of wages. Wages were obviously sinking rapidly, not only below the demands of the standard of living but actually in many instances below the possible requirements of physical existence. Was this phenomenon taken into account by the Ricardian doctrine? In 1835 the Governor-General of India reported: "The misery hardly finds a parallel in the history of commerce. The bones of the cotton weavers are bleaching the plains of India." And the situation of Europe's weavers was not much better. Consider, for instance, the following official figures, quoted by Professor von Schultze-

out shortly after Lassalle's death: the Malthusian doctrine of population preached by Lange himself. If this, however, is correct, then again I can not annul the law even if I abolish the wage system a hundred times over, for the law then dominates not only the wage system but every social system. Relying on this very fact, for fifty years and more economists have shown that socialism cannot annul that which is founded on nature, but on the contrary can only render it more general, spreading it over the surface of society." Neue Zeit, Jahrgang IX (I89I), vol. i, p. 570. 
Gaevernitz: " On an average good weavers in Bolton earned weekly:

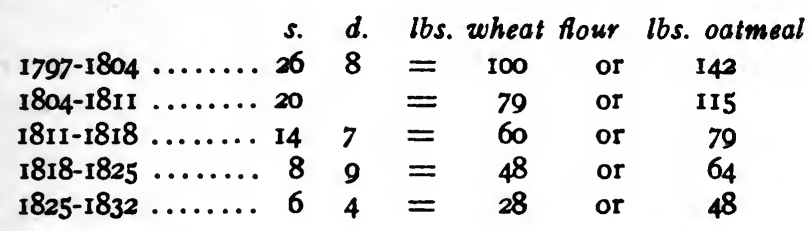

The stuff in question was at the time not yet produced by the power-loom. It permitted, therefore, the chance of far more favorable remuneration than the production, for example, of printing calico. There were even wages as low as 2s. to 3s. weekly." s The Silesian weavers were even worse off, they were actually dying of starvation. ${ }^{\circ}$ All this misery was, from the point of view of our economic classics, a situation for which nature alone was to blame. ${ }^{\text {? }}$

The growth of pauperism, the degradation and degeneration of the laboring class in the first half of the nineteenth century were not invented by socialist agitators. The facts were so tangible that the most con-

- Schultze-Gaevernitz, The Cotton Trade in England and on the Continent (London, I895), p. 31 .

- J. W. Worfr in Deutsches Bürgerbuch für 1845, pp. 174-202.

- A man who is born into a world already possessed, if he cannot get subsistence from his parents on whom he has a just demand, and if the society does not want his labor, has no claim of right to the smallest portion of food and, in fact, has no business to be where he is. At Nature's mighty feast there is no vacant cover for him. She tells him to be gone, and will quickly execute her own orders." Malthus, An Essay on the Principle of Population (2d ed., 1803), p. 531. 
servative economists of the time were the most emphatic in their condemnation of existing conditions and the first to demand checks and restrictions of the capitalist régime. The writings of the leading French and German economists and the speeches of Lord Ashley contain statements as drastic as any to be found in the socialist literature. The Communist Manifesto contains an attack upon the family - an attack which, we believe, Marx himself in later years regretted. There we read: "Abolition of the family! Even the most radical flare up at this infamous proposal of the Communists. . . The bourgeois clap-trap about the family and education, about the hallowed corelation of parent and child, become all the more disgusting, the more, by the action of modern industry, all family ties among the proletarians are torn asunder, and their children transformed into simple articles of commerce and instruments of labor." 8 But no less respectable and conservative a scholar than Robert von Mohl was lamenting as early as 1835 , that the workingman's wife and children were confiscated by the factory system, and that family life was utterly destroyed among the industrial proletariat." Nor was

${ }^{8}$ Communist Manifesto, pp. 39, 40.

- "Ueber die Nachteile, welche sowohl den Arbeitern selbst als dem Wohlstande und der Sicherheit der gesammten bürgerlichen Gesellschaft von dem fabrikmässigen Betriebe der Industrie zugehen, und über die Notwendigkeit gründlicher Vorbeugungsmittel," in K. H. Rau's Archiv der politischen Oekonomie und Polizeiwissenschaft (Heidelberg, I835), vol. ii, pp. 145, 146, 148, 15I, 156. 
the accusation wholly unwarranted that the industrial system was demoralizing the wives and daughters of laboring men. It was rather a common observation that the women, who to so large an extent were replacing skilled male laborers, were thrown at each industrial crisis on the streets as prostitutes. We have, for instance, the following statement from the chief constable of Bolton, Mr. Harris: "Unfortunate females who, in consequence of the cotton famine, were at its commencement thrown out of employment, have thereby become outcasts of society; and now though trade has revived and work is plentiful they continue members of that unfortunate class and are likely to continue so. There are also in the borough more youthful prostitutes than I have known for the last twenty-five years." 10

Yet, while acknowledging the unspeakable misery of the working class, our classical political economy had no word of solace and no ray of hope for the toilers. Even as late as 1874 one of the last true-blue representatives of classical political economy, Mr. Cairnes, had the admirable courage to state frankly and precisely his attitude. The possibility of any improvement of the living conditions of the industrial laborers "is confined within narrow barriers which cannot be passed, and the prob-

${ }^{10}$ Reports of the Inspectors of Factories for the half-year ending October 31, 1865. London, 1866, Parliamentary Papers, Session I February-10 August, 1866, vol. xxiv. 
lem of their elevation is hopeless. As a body they will not rise at all. A few, more energetic or more fortunate than the rest, will from time to time escape, as they do now, from the ranks of their fellows to the higher walks of industrial life, but the great majority will remain substantially where they are. The remuneration of labor as such, skilled or unskilled, can never rise much above its present level." 11 This was not so much an expression of a personal opinion as a logical deduction from the classical wage-fund doctrine, of which Mr. Cairnes was, if we are not mistaken, the last champion. The tenacity with which political economy clung to so crude a doctrine as the wage-fund theory, a theory which was so palpably below the high mental level which its authors otherwise maintained, can be explained only psychologically. It was a semi-unconscious device for shirking all responsibility for the truly barbarous condition into which the British proletariat was sinking; it was an ingenious apology for the neglect of all moral obligations by state and society, a strong defense of laissez faire, putting all the blame for shame and crime and dishonor on the Almighty and his immutable laws.

The wage-fund argument was, roughly speaking, that the general amount of capital is determined by society's past exertions, by the accumulated savings and profits of the past. Out of this sum a certain

${ }^{11}$ Catrnes, Some Leading Principles of Political Economy Newly Expounded (London, I874), p. 348. 
amount is required for plant and material, the amount being determined by the technical character of industry. The free balance is the wage fund, thus a fixed and predetermined amount. More than that amount the wage-earners cannot possibly receive, less than that amount they never obtain. The rate of wages therefore depends upon the number of wage-earners. Their number is the divisor, the wage fund the dividend. And here comes in the Malthusian doctrine. If the number of wage-earners is great, their wages are low. Low wages check the increase of population, hence wages rise. There is, therefore, no use in blaming anybody or anything; one might as well blame the four fundamental rules of arithmetic. The question of wages is a question of division. If, however, the wage-earning population should so decrease and wages so rise as to diminish profits, the accumulation of capital would thereby automatically be diminished, the wage fund would contract, and wages be bound to sink again. Neither unionism nor legislation can affect the situation-not even if thereby the efficiency of the wage-earners be increased and the profits of the capitalist class thus remain undiminished. As Sidney and Beatrice Webb have pointed out, this theory "left no room for any elevation of the wage-earners even if the improvement justified itself by an increase in productive capacity. If one section of the wageearners succeeded, by peaceful negotiation or law, in so bettering their own conditions of employment as 
positively to increase their productive efficiency, this would still bring no greater reward to the class as a whole. Though the increase in the cost of their labor might soon be made up to their employers by its greater product, yet this increased drain on the wage fund must automatically have depressed the condition and so lowered the efficiency of other sections, with the result that, though the inequality between the sections would have increased, the aggregate efficiency of the wage-earners as a whole would not have risen. Thus every factory act, which increased the immediate cost of woman or child labor, had to be paid for by a contemporaneous decrease in somebody's wages; and every time a new expense for sanitation or precaution against accidents was imposed on the capitalists, some of the wage-earners had automatically to suffer a diminution of income." 12

Thus, as the reader can readily observe, any attempt to alleviate the living and working conditions of the laboring class could be resisted on high moral grounds: according to the laws of political economy the reform would hurt the very class it sought to help! "For a time, indeed, a natural influence may be dammed back, but only to act, ultimately, with accumulated force. In the long run, God's laws will overwhelm all human obstructions." ${ }^{13}$ Consequently those

12 Sidney and Beatrice WebB, Industrial Democracy (London, 1902), p. 607. The italics are mine.

"James Stirling, Trade Unionism (1889), p. 27, quoted in 
who objected to the most ruthless methods of exploiting child labor were charged with betraying the very palladium of British liberties, with " undermining the laws of political economy, with assailing God's own established order." And thus we see a Harriet Martineau lamenting in 1833 over the first faint regulations of child labor. Shocked as she was by the official disclosures in regard to the subject, she could not tolerate any legislative interference, any social control; it was against political economy. But a woman's heart is not without mercy, so she hoped that children engaged in industry might die! "The case of those wretched factory chitdren seems desperate; the only hope seems to be that the race will die out in two or three generations; by which time machinery may be found to do their work better than their miserable

WeBs's Industrial Democracy, p. 6ri. Mr. Stirling was after all but a commonplace interpreter of "God's laws." The palm in this line belongs to the English economist, the Rev. J. Townsend, who wrote under the name "The Wellwisher of Mankind" against the Poor Law. In his masterpiece, which lived to see a second edition-A Dissertation on the Poor Law's (London, 1817), pp. 39-4I, quoted by Marx, Capital, I, pp. 602, 603-he explains to us that the poor are improvident and multiply rapidly in order "that there may always be some to fulfil the most servile, the most sordid and the most ignoble offices in the community. The stock of human happiness is thereby much increased, whilst the more delicate are not only relieved from drudgery ... . but are left without interruption to pursue those callings which are suited to their various dispositions." The Poor Law "tends to destroy the harmony and beauty, the symmetry and order of that system which God and Nature have established in the world." 
selves." 14 Miss Martineau forgot that machines were invented precisely for the purpose of substituting child labor for skilled adult labor.

But Marx remembered it; he knew Ure's Philosophy of Manufactures by heart. ${ }^{15}$ And yet Marx and Engels did not escape the dogmatic fascination of the "economic law." It is this circumstance which stamped Marx as a classical economist. In the fifties Marx, and Engels also, regarded any attempt to regulate economic conditions by the law of the land as fruitless meddling, reactionary in its effect. We find them anathematizing the ten-hour law in language worthy of Nassau Senior. "The whole social development of England depends upon the development and progress of its industry. All institutions, which interfere with its progress, which try to regulate and control it . . . are reactionary and untenable." 16 From this classical doctrine Marx and Engels, however, drew the conclusion that, since reforms cannot mend the situation, the economic development is bound to lead to a revolution. "And so the only solution of the ten-hour problem, as of all problems

"Harriet Martineau's Autobiography, by Maria W. ChapMAN (London, 1877), vol. iii, p. 87. Quoted in WEBB, op. cit., p. 608.

18 "The effect of substituting the self-acting mule for the common mule is to discharge the greater part of men spinners and to retain adolescents and children." URE, Philosophy of Manufactures (London, 1835), p. 23.

"In Marx's Neue Rheinische Zeitung, Heft 4 (London, 1850), p. 13 . 
arising from the antagonism of capital and labor, is the proletarian revolution." 17

There are two main principles of government, and they are mutually exclusive: the one of social control and state intervention; the other of consistent laissez faire, the state guaranteeing property and free contract and then limiting its functions to those of a policeman and night-watchman. It is obvious that economic tendencies can be watched, checked and modified from the point of view of the first principle, but from the other point of view these tendencies are manifestations of immanent and sovereign laws, independent of our desires and our actions. Classical political economy represented at the same time advocacy of the laissez faire principle and a theoretical explanation of the phenomena which arise under it.

In his Capital Marx abandoned his old view of the ten-hour bill and became an inconsistent advocate of social control, but he remained a typical classical freetrader in his theory. He took it for granted that the capitalist mode of production is based on non-interference and free trade, and, with exceptional acumen, he worked out its laws and tendencies, which pointed to a general cataclysm of capitalist society and to a social revolution. Yet Marx himself witnessed the

${ }^{17}$ Ibid., p. 16. See also Aus dem literarischen Nachlass von Karl Marx, Friedrich Engels, etc., vol. iii (Stuttgart, 1902), p. 395. 
passing of the laissez faire stage of English capitalism and the reintroduction of social control-the ten-hour bill, the factory acts, etc. He appreciated their importance. There is abundant proof that he realized that he was witnessing the victory of a new principle. But it was too late; his theory was made up and was fixed in his mind. As a theory, it was profound, but it was unrelated to the transformation which was going on before his eyes. Lassalle's prediction that Marx would be a combination of a Hegel turned economist and a Ricardo turned socialist ${ }^{18}$ was completely verified. Marx did develop and apply the economic principles of Ricardo, and the change of tableaus in Hegel's historical process he expected from the self-destruction of capitalism. He was on the lookout for a death certificate, and did not notice that the factory acts and social control signified either a new lease of life for capitalism or the new tableau he was looking for, the dawn of a new era.

Now let us see how Marx came to this doctrine of increasing misery as a law of capitalist society. The iron law of wages, as we have already seen, did not account for the actual steady sinking of wages. Nor was the Malthusian side of the iron-law doctrine acceptable to Marx. Neither of these theories made any such impression upon him as that which he received from Andrew Ure's discussion of the purport

"Briefe von Ferdinand Lassalle an Karl Marx (Stuttgart. 1902), p. 30. The letter cited is dated May 12, 1851. 
and effect of machinery: "The effect of improvements in machinery not merely in superseding the necessity for the employment of the same quality of adult labor as before, in order to produce a given result, but in substituting one description of human labor for another, the less skilled for the more skilled, juvenile for adult, female for male, causes a fresh disturbance in the rate of wages." ${ }^{19}$ Upon these facts, which were matters of common observation, Marx built his theory of wages and population. From these data it followed that in industrial society a surplus population, pauperism of the unemployed, and low wages of the employed are due to technical improvements. While Malthus's law may apply to plants or animals, it is not written for modern industrial life, since an entirely new element comes in, that of industrial technique, and this element is the decisive one. In fact, without a large surplus population of operatives, without an industrial reserve army, capitalist industry could not exist, since it could not adjust itself to the fluctuations which are essential to an unorganized competitive mode of production. Without a reserve army on call, the times of prosperity could not be utilized, and the increased demand could not be supplied for lack of factory hands. This reserve army is created and maintained by the introduction of new machinery or by technical improvement of the old. It acts as a dead weight of pauperism upon the active industrial ${ }^{10}$ URE, Philosophy of Manufactures (London, 1835), p. 32r. 
army. Wages are depressed and become insufficient for the physical maintenance of the laborers' families. The improved machinery permits the employment of women and children, the insufficient wages of the men compel it. Thus the proletarian family is destroyed; it becomes a group of factory hands. The large amount of " constant" capital, i.e., capital invested in the plant, suggests its longer and intenser utilization. As a result comes the prolongation of the working day. "When a laborer," says a cotton manufacturer quoted by Nassau Senior, "lays down his spade, he renders useless a capital worth eightpence. When one of our people leaves the mill he renders useless a capital that has cost $£_{100,000 . " 20}$ Hence the demand for longer hours, a demand which the laborer cannot resist because of the competition of the industrial reserve. Machinery, as Ure explained, turns the flanks of the laboring army and compels it to "surrender at discretion"; and every bit of machinery " confirms the great doctrine already propounded, that when capital enlists science into her service the refractory hand of labor will always be taught docility." ${ }^{21}$

If Ure explained the origin of an industrial reserve army, Professor Merivale, whose writings Marx studied, suggested the industrial reserve army as an indispensable condition for modern industry. If as a

${ }^{30}$ Sentor, Letters on the Factory Acts (London, 1837), pp. 13. 14.

${ }^{21}$ URE, op. cit., pp. 368-370 et passim. 
result of bad times the unemployed should emigrate to some other country, reasoned Merivale, then with the return of prosperity there will not be a sufficient supply for the increased demand for labor. The factory hands may get better wages; they may breed, according to Malthus, more freely; but still, he continues, " however rapid reproduction may be, it takes, at all events, the space of a generation to replace the loss of adult labor. Now, the profits of our manufacturers depend mainly on the power of making use of the prosperous moment when demand is brisk, and thus compensating themselves for the interval during which it is slack. This power is secured to them only by the command of machinery and of manual labor. They must have hands ready for them, they must be able to increase the activity of their operations when required, and to slacken it again, according to the state of the market." 22 This was of course Marx's point of view. The economic implications of commercial depressions Marx could not overlook. On the commercial crisis Marx rested his hope of the final cataclysm of capitalist society. The analysis of industrial crises was perhaps the chief contribution of Marx's French predecessors, Fourier and Sismondi, ${ }^{23}$ which Marx, as usual, gladly acknowledged. ${ }^{24}$

"2 H. Merrvale, Lectures on Colonization and Colonies (1841), vol. i, p. 146.

"2 CH. ANdLer, Le Manifeste Communiste, vol. ii, Introduction historique et commentaire (Paris, 1901), pp. 99-102.

"Menger and some other writers have wasted a good deal 
One can therefore easily imagine how little use Karl Marx had from this point of view for the wagefund apologists, whose sentiments may be summed up in Harriet Martineau's advice to the laboring class: "We manufacturers do what we can, whilst we are increasing that capital on which you must subsist, and you must do the rest by accommodating your numbers to the means of subsistence!" ${ }^{25}$ Marx's scorn for Malthusianism and for the wage-fund theories was, however, intellectual rather than moral. He had, as we have seen, as little hope for the rise of the laboring class as any of his contemporaries. But he could not assume that low wages are due to overpopulation, that after the population has been decimated wages rise, that with the rise of wages the population increases and so on. "A beautiful mode of motion this for developed capitalist production!" he exclaims. "Before, in consequence of the rise of

of time in trying to demonstrate the sources from which Marx borrowed his system. In literary matters Marx was extremely punctilious. His erudition was colossal, and wherever he was conscious of borrowing an idea he invariably acknowledged it. Apart from such acknowledged borrowings he was unconsciously influenced, without doubt, by many writers and by many political and social occurrences, and from the psychological and the historical points of view it is interesting to trace these influences; but it is folly to search for a predecessor from whom Marx borrows his system. There is not a single separate idea in the system of Marx which was not formulated or suggested by previous writers, but the combination of these ideas in one colossal structure is Marx's own achievement.

"Harriet Martineau, The Manchester Strike (1842), p. Ior. 
wages, any positive increase of the population really fit for work could occur, the time would have been passed, again and again, during which the industrial campaign must have been carried through, the battle fought and won." 28

On the other hand the wage-fund theory was not without influence upon Marx, especially since in the ultimate result-the assumed impossibility of any rise of the working class-Marx was entirely in accord with his contemporaries and predecessors. Thus, in somewhat different words, Marx re-states the classical theory, emphasizing the expansion and contraction not of population but of production: "Accumulation slackens in consequence of the rise of the price of labor, because the stimulus of gain is blunted. The rate of accumulation lessens; but with its lessening the primary cause of that lessening vanishes, i.e., the disproportion between capital and exploitable laborpower. The mechanism of the process of capitalist production removes the very obstacle that it temporarily creates." 27 In other words, since in capitalistic society the laborer exists for the increase of existing values and not vice versa, every rise in wages which will endanger the continual expansion of capital is excluded. ${ }^{28}$ With the accumulation of capital the proportion of constant to variable capital changes, i.e.,

\footnotetext{
20 Marx, Capital, vol. i, p. 652.

"Ibid., p. 633.

"Ibid., p. 634.
} 
the amount of capital invested in plant and machinery in relation to the amount spent on wages is not as it was originally-not, let us say, I : I, but $2: I, 3: I$, $4: I, 6: I, 8: I$, etc. Since the demand for labor is determined not by the amount of capital as a whole, but by its "variable" constituent alone, i.e., by the amount spent on wages, the demand for labor falls progressively with the increase of the total capital, the largest part of which is now being transformed into means of production, i.e., machinery, etc. ${ }^{29}$ Machinery and other improved means of production, as we have seen, create a surplus population. "The laboring population therefore produces, along with the accumulation of capital produced by it, the means by which itself is made relatively superfluous, is turned into a relative surplus population; and it does this to an always increasing extent. This is a law of population peculiar to the capitalist mode of production." 30

But the surplus population, the industrial reserve army, as we have seen, is itself a lever of capitalistic accumulation, in fact a condition of existence of the capitalist mode of production. The course characteristic of modern industry-let us say a decennial cycle of average activity, production at high pressure, crisis and stagnation-depends upon the existence of an industrial army, the greater or lesser absorption of which at any time corresponds to the momentary degree of productive activity. In periods of stagnation,

so Ibid., p. 643.

30 Ibid., p. 645 . 
the active labor army is weighed down by the industrial reserve army. In times of prosperity the reserve army still holds the pretensions of labor in check. It is thus the pivot upon which the law of demand and supply of labor works. Pauperism, pauperism on an ever-increasing scale, is therefore a necessary part of the system; it enters into the faux frais of capitalistic production. And Marx formulates his theory of increasing misery as follows:

"The folly is now patent of the economic wisdom that preaches to the laborers the accommodation of their number to the requirements of capital. The mechanism of capitalist production and accumulation constantly affects this adjustment. The first word of this adaptation is the creation of a relative surplus population, or industrial reserve army. Its last word is the misery of constantly extending strata of the active army of labor, and the dead weight of pauperism.

"The law by which a constantly increasing quantity of means of production, thanks to the advance in the productiveness of social labor, may be set in movement by a progressively diminishing expenditure of human power, this law, in a capitalist society, where the laborer does not employ the means of production but the means of production employ the laborer, undergoes a complete inversion and is expressed thus: the higher the productiveness of labor, the greater is the pressure of the laborers on the means of employment, the more 
precarious, therefore, becomes their condition of existence, viz., the sale of their own labor power for the increasing of another's wealth, or for the self-expansion of capital. The fact that the means of production and the productiveness of labor increase more rapidly than the productive population, expresses itself, therefore, capitalistically in the inverse form, that the laboring population always increases more rapidly than the conditions under which capital can employ this increase for its own self-expansion. Within the capitalist system all methods for raising the social productiveness of labor are brought about at the cost of the individual laborer; all means for development of production transform themselves into means of domination over and exploitation of the producers; they mutilate the laborer into a fragment of a man, degrade him to the level of an appendage to a machine, destroy every charm in his work and turn it into a hated toil; they estrange from him the intellectual potentialities of the labor process in the same proportion as science is incorporated in it as an independent power; they distort the conditions under which he works, subject him during his labor process to a despotism the more hateful for its meanness; they transform his lifetime into working time, and drag his wife and child beneath the wheels of the Juggernaut of Capital. But all methods for the production of surplus value are at the same time methods of accumulation; and every extension of accumulation becomes 
again a means for the development of these methods. It follows therefore that in proportion as capital accumulates, the lot of the laborer, be his payment high or low, must grow worse. The law, finally, that always equilibrates the relative surplus population or industrial reserve army to the extent and energy of accumulation, this law rivets the laborer to capital more firmly than the wedges of Vulcan did Prometheus to the rock. It establishes an accumulation of misery, corresponding with accumulation of capital. Accumulation of wealth at one pole is therefore at the same time accumulation of misery, agony of toil, slavery, ignorance, brutality, mental degradation, at the opposite pole." 31

This is Marx's theory of increasing misery. At the end of the first volume of his Capital, summing up and giving an account of the general historical tendencies of accumulation, he clearly indicates whither the increasing misery of the working class is bound to lead. Along with the concentration of industry and centralization of capital " grows the mass of misery, oppression, slavery, degradation, exploitation; but with it too grows the revolt of the working class, a class always increasing in numbers, and disciplined, united, organized by the very mechanism of the process of capitalist production itself." 32

Such is the doctrine, a doctrine embracing a theory of population and a law of wages, and formulating

"Marx, Capital, vol. i, pp. 660, 66r.

"2 Ibid., p. 789. 
a tendency which leads inevitably and necessarily to

a social revolution and socialism. It is undoubtedly an ingenious doctrine; its critique of Malthusianism and of wage-fund theories is as a whole well taken; yet it was destined to share the fate of preceding economic doctrines. Life in its development has betrayed them and left them behind. And their value is now but that of historical monuments.

It has already been pointed out that the Marxian theory which we are now discussing is framed on the presupposition of consistent individualism, non-resistance on the part of the laboring class until no alternative to revolution is left, non-interference on the part of the state, with economic life reduced to a mechanical entity, till the very mechanism of economic life makes the existent state impossible. Were it not for the circumstance that Marx witnessed the introduction of the factory acts and the resumption of social control on the part of the state, his theory would have been open to criticism only as defective in its psychology. Considering that he lived to see these changes, his theory is open to sharper criticism: it dealt with a fictitious society, and the result was a fictitious doctrine, based on the facts as they had been, but unrelated to the facts as they were, and therefore without claim to reality and truth.

It is indeed evident that Marx saw how trade unionism alone might undermine and render worthless his wage law and his whole theory of increasing 
misery. He wrote: "As soon, therefore, as the laborers learn the secret, how it comes to pass that in the same measure as they work more, as they produce more wealth for others, and as the productive power of their labor increases, so in the same measure even their function as a means of the self-expansion of capital becomes more and more precarious for them; as soon as they discover that the degree of intensity of competition among themselves depends wholly on the pressure of relative surplus population; as soon as by trades unions, etc., they try to organize a regular cooperation between employed and unemployed in order to destroy or to weaken the ruinous effects of this natural law of capitalistic production on their class, so soon capital and its sycophant, political economy, cry out at the infringement of the 'eternal' and, so to say, 'sacred' law of supply and demand. Every combination of employed and unemployed disturbs the 'harmonious' action of this law." ${ }^{33}$ So Marx acknowledged that trade unionism might weaken or even destroy the " natural law" of wages. And that unionism has done it is beyond question. Organized labor has succeeded in steadily improving its living conditions. In 1892 , in his preface to the second edition of his book on the working class in England, Frederick Engels had to acknowledge it and sadly to admit the fact that, with the improved conditions, the revolutionary spirit of the Chartist epoch had sub-

"Marx, Capital, vol. i, p. 655. The italics are mine. 
sided. He wrote: "The engineers, the carpenters, joiners and bricklayers are each of them a power, to that extent that, as in the case of the bricklayers and bricklayers' laborers, they can even successfully resist the introduction of machinery. That their condition has remarkably improved since 1848 there can be no doubt, and the best proof of this is the fact that for more than fifteen years not only have their employers been with them, but they with their employers, upon exceedingly good terms. They form an aristocracy among the working class; they have succeeded in enforcing for themselves a relatively comfortable position and they accept it as final. They are the model workingmen of Messrs. Leone Levi and Giffen, and they are very nice people indeed nowadays to deal with, for any sensible capitalist in particular and for the whole capitalist class in general." 34 The "natural law" of capitalist production had failed to work. Not only was misery not on the increase, but the conditions of the so-called aristocracy of labor, as Engels himself acknowledged, had remarkably improved.

There is also an official ex cathedra statement of Marx in regard to this matter, a statement which opens up an extremely interesting psychological question. Marx published the first volume of his Capital in 1867 . In it he developed his theory of increasing misery. Yet in 1864 , while he was elaborating that

"Fr. Engers, The Condition of the Working Class in England in 1844 (London, 1892), p. xv. The italics are mine. 
volume, he openly abandoned this theory. In his book, it must be remembered, this theory is a central doctrine. Not only does it embody his theory of population and his wage law, but upon it is based his progressively intensified class-struggle doctrine; and, furthermore, it is a vital part of his theory of the inevitable catclysm of capitalistic society. The statement just made, that he abandoned the increasing misery theory in 1864 , is based on what he said in his inaugural address before the International Workingmen's Association in that year: "After a thirty years' war conducted with wonderful endurance, the English working class succeeded in utilizing a temporary clash between the landed aristocracy and the moneyed aristocracy, and the ten-hour bill was put through. Everybody acknowledges now its significant physical, moral and intellectual advantages for the working class, which are chronologically now recorded in the semi-annual reports of the factory inspectors. The majority of the continental governments feel themselves also obliged to introduce the English factory acts with greater or less diminishing, and the British Parliament is compelled to enlarge from year to year the sphere of influence of the factory acts. The wonderful results of this labor measure were of more than mere practical significance. The notorious mouthpieces of the British bourgeoisie, scholars like Dr. Ure, Professor Senior and wiseacres of the same type, prophesied and proved to their own 
heart's satisfaction that any legal limitation of the working day would chime the death hour of British industry-an industry which like a vampire could thrive only on blood, children's blood above all. The struggle for the legal limitation of the working day was the more bitter, because it was not merely a check upon individual greed, but also a direct intervention in the great battle waged between the blind law of supply and demand-the political economy of the bourgeois-and the principle of social regulation of production, which is the quintessence of the political economy of the laboring class. And therefore the tenhour bill was not only a great practical success, it was the victory of a principle. In the bright sunlight of day the bourgeois political economy was here vanquished for the first time by the political economy of the working class." 35 Thus Marx himself threw overboard his theory of increasing misery. The victory of the new principle meant the defeat of the principle upon which the whole Marxian theory rests, the crumbling of his whole economic system, of all his economic proofs and evidences of the inevitable dies irae, of the cataclysm of our whole economic organization. The foundation upon which Marx's entire work was built, the inevitable laissez faire, Marx himself ac-

35 Inaugural Address delivered by Marx, September 28, 1864. in St. Martin's Hall. Der Vorbote, politische und sozialökonomische Zeitschrift, Centralorgan der Sektionsgruppe deutscher Sprache der Internationalen Arbeiterassociation, redigirt von Joh. Phil. Becker (Genf. 1866), pp. 38-39. 
knowledged to have been washed away even before his work was ready for print, before he finished its architectural details.

Anybody who studies the first volume of Capital can see there the unconscious conflict of the two principles, - on one hand the elaboration of a purely economicomechanic system, not as a theoretical possibility but as an actual tangible reality predestined to run itself to ruin in its own course; and on the other hand the acknowledgment of the salutary and modifying effects of social control, which determines the character of the economic phenomena.

If the Marxian theory were a " static state" theory, any tendency indicating the direct opposite of what the theory claims could be classed by the Marxists as one of those "slight" deviations of a temporary character due perhaps to man-made law, which is after all of little concern to truth everlasting. But Marx's just claim to fame rests precisely on his refusal to traffic in eternal verities. His economic laws are laws of capitalist production only. Every economic epoch has its own laws, but they are laws of development, laws actually governing the economic tendencies. If, therefore, the actual facts flatly contradict the theory, as they do, there remains but the alternative either to deny the facts or to repudiate the theory.

Both alternatives have found their champions. Some imaginative and enterprising socialists, not weighed down with too much learning, deny the facts 
of the case; others claim that the doctrine of increasing misery is but a minor and non-essential point, which could and should be dropped as immaterial and irrelevant to the Marxian theory and to scientific socialism. So for instance Franz Mehring, a Marxist, justly held in high esteem by the socialists of his country on account of his learned historical works, makes the curious statement that the theory of increasing misery is but a relic inherited by Marx from the bourgeois political economy, which has lost long ago what little sense and justification it might once have had and which has nothing in common with orthodox Marxism. ${ }^{36}$ Schönlank, a German socialist of marked ability, frankly admits that the theory of increasing misery is untenable. ${ }^{37}$ The same is the attitude of

so "How long the party will continue to find satisfaction in these discussions we do not know, but even were it to do so for as many years in the future as it already has in the past, not a particle of use would arise from it. And for the simple reason that the theory of increasing misery long since lost whatever import and acceptance it may have had in the past. A product of bourgeois political economy when that was still unbiassed, it has nothing to do with 'orthodox Marxism.'" Menring, "Historisches zur Verelendungstheorie," Neue Zeit, Jahrgang XX (Stuttgart, 1902), vol. i, pp. 164, I65.

87 " The theory of misery in the absolute sense which long was current in our party, and the theory of constantly increasing misery which still finds expression in the first part of the Erfurt program, are no longer tenable!" Leipziger Volkszeitung, 1897 , quoted in the "Bernstein-Debatte" in Hanover. Protokoll wiber die Verhandlungen des Parteitages der sozialdemokratischen Partei Deutschlands, abgehalten zu Hannover, Oktober 9-14, 1899, pp. 137, 138. 
David, who urges his comrades to acknowledge the mistake. $^{38}$

And yet the true-blue Marxists are unwilling to drop this theory. They realize that in dropping it they are dropping Marxism, but they do not realize that in interpreting it away they are interpreting Marxism away. The whole construction of Marx's Capital leads up to the doctrine of increasing misery. In rejecting this theory, one rejects also Marx's theory of population, his theory of wages, his theory of accumulation of capital. And if what is left be Marxism, it is Marxism with Marx left out. Not only is his theory shattered, but what rational foundation is there left for his vision and hope, his goal and inspiration-the breakdown of capitalism and the social revolution? These conceptions of Marx as well as his idea of the general crisis are based upon the progressively increasing misery of the working class. ${ }^{80}$

is "Let us not play at hide-and-seek, but let us quietly explain : the position of the program in regard to increasing misery is a mistake." Ibid., p. I38.

"So Peter Struve points out "that the theory of a cataclysm as a theory of a general crisis necessarily leads back to the doctrine of increasing misery." Peter von STRUve, "Die Marx'sche Theorie der Sozialen Entwicklung," Braun's Archiv für soziale Gesetzgebung und Statistik, vol. xiv, 1899, p. 695. 


\section{CHAPTER VII}

\section{DATA RELATING TO THE STATUS OF THE WAGE-EARNER}

Since the Marxian system cannot without wrecking its theory disavow the doctrine of increasing misery of wage-earners, it devolves upon us to test this doctrine by the actual facts of economic life, i.e., by wage statistics. Relatively easy as it is to obtain figures of wages for long periods, their scientific utilization presents considerable difficulties. The data have invariably been gathered and controlled by different methods; the money wage of the time and the purchasing power of the wage varied greatly. The task is therefore not a grateful one, and no historical statements of wages based upon miscellaneous statistics can lay claim to mathematical exactness. And yet in spite of all the inevitable inaccuracies, these statistical data suffice to establish the general tendencies beyond a shadow of reasonable doubt.

A valuable supplement to the ordinary statistics of workingmen's earnings are the budgets of the wageearner's expenditures. Although budget literature is now being traced back to Sir William Petty and his Political Arithmetic, for our purposes only material 
of much later date is of interest. We may start with a contemporary of the Communist Manifesto-Dr. Alexander v. Lengerke's Ländliche Arbeiterfrage," which is a very important volume. The itemized expenditures are estimates, but they are carefully and minutely considered estimates submitted at the request of the Prussian government by 185 local agricultural societies, and they all relate to the probable expenditures of peasant families consisting of five members.

This investigation embraces agricultural laborers and peasants who supplement their income from farming by outside agricultural labor. One hundred and fifteen thalers was the average income of such families throughout Prussia in $1848 ;{ }^{2}$ and on an average not less than 96 per cent of their budget went for the satisfaction of the elementary physical wants: food, shelter, clothing, fuel and fodder. The remaining 4 per cent was spent on "Abgaben an Staat, Kirche, Schule." Since taxes may well be estimated at about 3 per cent, it left but I per cent for non-physical wants. ${ }^{3}$

${ }^{1}$ Die ländliche Arbeiterfrage. Beantwortet durch die bei dem königlichen landes-Oekonomie-Collegium aus allen Gegenden der breussischen Monarchie eingegangenen Berichte landwirtschaft3icher Vereine über die materiellen Zustände der arbeitenden Classen auf dem platten Lande. Berlin. Im Bureau des königl. Ministeriums für landwirtschaftliche Angelegenheiten 1849. The volume is rare, but there is a copy in the Library of Congress.

Ibid., p. 13.

- See also on the subject, ERnst Engers, Die Lebenskosten Belgischer Arbeiter-Familien, Dresden, 1905, p. 19. 
An enquête on similar lines covering the whole of Germany was undertaken in 1872 . The results were published by Professor von der Goltz in $1875,{ }^{4}$ and show an extraordinary material improvement of the living conditions of the agricultural laborers. The expenditures of a family of five were in Prussia Mk. 632.7 instead of Mk. $3^{15} \cdot 30$ as in 1848 , and throughout Germany the average expenditure amounted to Mk. $717 .^{5}$

The great material advance of the agricultural la-

- Die Lage der ländlichen Arbeiter im Deutschen Reich. Unter Mitwirkung von Prof. Richter, v. Langsdorff, erstattet von Dr. Th. Frh. von der Goltz, Professor an der Universität Königsberg, Berlin, 1875. (A copy in the Cornell University Library.)

'ENGels, op. cit., p. 19. "With regard to intellectual culture progress may be noted more frequently than with regard to morals. . . .

"With regard to the material situation. Here an almost general improvement in the material condition of the agricultural laborers is proved, but at the same time it is evident that they have not become more economical." . . .

Dr. v. d. Goltz goes on to show that within the last 30 years prices increased as follows: rye, 25 per cent, potatoes 31 per cent, butter 48 per cent and meat 53 per cent; but wages increased in most provinces in the neighborhood of 100 per cent while many articles of consumption (especially "Colonialwaaren") decreased in price. He also reminds us of the fact that the products which increased in price are chiefly produced by the agricultural laborers themselves on their plots of land, or they receive it as a "Naturaldeputat" from their employer. Professor von der Goltz therefore comes to the conclusion: "After what has been said we are obliged to emphasize the fact that the statement which was made with such unanimity in the committee in regard to the actual improvement in the material condition of the agricultural laborer was thoroughly warranted." TH. vON DER GoLTZ, loc. cit., pp. $496,497,498$. 
borer and the rise in his standard of living were reported in every part of the German Empire.

And yet, as we have previously pointed out, the Communist Manifesto must not be regarded as a rhetorical exercise of a mere demagogue. In the midst of its fiery revolutionary eloquence the Manifesto shows more regard for facts than many a learned work of its time. The Manifesto is in truth but a reflection of the effects of early industrialism; it was written under the fresh impression of hunger riots of the Silesian weavers, which Heine and Hauptmann have immortalized. ${ }^{6}$ It is therefore especially fortunate that one of the most careful budget studies should cover the economic status of the Silesian textile workers during the period of I865-1874. This study was made by Karl Schwedler, ${ }^{7}$ the manager of a local coöperative society (Consumverein). All the prices were taken from the actual account books, the sums spent minutely itemized, the increase in rent not overlooked: in short the study is exceptionally trustworthy. Here are the results: Schwedler's tables show that in

- Heine's famous poem, "Die Weber," begins with these lines: "Im düstren Auge keine Thräne, Sie sitzen am Webstuhl und aetschen die Zähne: Deutschland, wir weben dein Leichentuch, Wir weben hinein den dreifachen Fluch, Wir weben, wir weben!" r" No tears in their sad eyes, they sit at the loom and grimly mile; Germany, we weave your shroud, into it we weave a (hreefold curse, we weave, we weave!")

"Karl Sch wedrer, "Arbeitslöhne in der Schlesischen Textilindustrie und Unterhaltsbedarf in den letzten Io Jahren." In the lrbeiterfreund, vol. xii, Berlin, I875, pp. 149 ff. 
the ten years prices advanced 35 per cent. Wages on the other hand advanced, for men, 60 per cent ; women, 29 per cent ; girls, 50 per cent ; boys, 50 per cent. ${ }^{8}$

What percentage of these increasing wages forms a surplus over the merely physical necessities of life and the allowance for its fuller development? An interesting table, which answers this question, is to be found in a recent curious Russian book by S. Solncev. ${ }^{\circ}$ Solncev used the Berlin workingmen's budgets collected in 1879,1896 and 1900 by Berlin statisticians.

\begin{tabular}{|c|c|c|c|c|c|c|}
\hline & \multicolumn{6}{|c|}{ EXPENDITURES PER PERSON IN A FAMILY } \\
\hline & \multicolumn{3}{|c|}{ IN MARKS } & \multicolumn{3}{|c|}{$\begin{array}{l}\text { PER CENT TO ALL } \\
\text { EXPENDITURES }\end{array}$} \\
\hline & 1879 & 1896 & 1900 & 1879 & 1896 & 1900 \\
\hline $\begin{array}{l}\text { 1. Rent } \ldots \ldots \ldots \ldots \ldots \ldots \\
\text { 2. Furniture } \ldots \ldots \ldots \ldots \ldots \\
\text { 3. Fuel } \ldots \ldots \ldots \ldots \ldots \ldots \\
\text { 4. Light } \ldots \ldots \ldots \ldots \ldots \ldots \\
\text { 5. Clothing, wash, etc.... } \\
\text { 6. Food } \ldots \ldots \ldots \ldots \ldots \ldots \ldots \\
\text { 7. Drinks and food in } \\
\text { restaurants, etc.... } \\
\text { 8. Care of health, etc... }\end{array}$ & $\begin{array}{r}52.0 \\
6.8 \\
19.7 \\
5.0 \\
39.7 \\
156.7 \\
\\
17.0 \\
7.4\end{array}$ & $\begin{array}{r}60.6 \\
? \\
16.3 \\
4.2 \\
33.3 \\
171.9 \\
\\
20.5 \\
5.9\end{array}$ & $\begin{array}{r}76.5 \\
? \\
18.9 \\
5.7 \\
49.7 \\
203.2 \\
\\
9.5 \\
4.8\end{array}$ & \begin{tabular}{r|}
16.3 \\
2.2 \\
6.0 \\
1.6 \\
12.4 \\
48.9 \\
\\
5.3 \\
2.3
\end{tabular} & $\begin{array}{r}17.3 \\
? \\
4.7 \\
1.2 \\
10.0 \\
48.1 \\
\\
5.8 \\
2.0\end{array}$ & $\begin{array}{r}17.01 \\
? \\
4.18 \\
1.25 \\
11.06 \\
45.01 \\
2.16 \\
1.03\end{array}$ \\
\hline $\begin{array}{l}\text { A. Expenditures of a } \\
\text { physical nature } \ldots . \\
\text { B. Expenditures non- } \\
\text { physical } \ldots \ldots \ldots \ldots\end{array}$ & $\begin{array}{r}304.3 \\
\text { I6.I }\end{array}$ & $\begin{array}{r}322.7 \\
38.2\end{array}$ & $\begin{array}{r}368.3 \\
81.3\end{array}$ & $\begin{array}{r}95.0 \\
5.0\end{array}$ & $\begin{array}{r}89.4 \\
\text { 10.6 }\end{array}$ & $\begin{array}{l}81.73 \\
18.27\end{array}$ \\
\hline Total $\ldots \ldots \ldots$ & 320.4 & 360.9 & 449.6 & 100. & 100. & I00. \\
\hline
\end{tabular}

' Karl Schwedler, loc. cit., p. 153.

- S. SolnCEv, Rabachie budgeti v svyazi s teoriey "obednenia," 1907 , p. 69. 
Non-physical expenditures, which practically did not exist in agricultural districts in 1848 , have gradually risen from 5 per cent in 1879 to 18 per cent in 1900 in family households. In 1903 the non-physical expenditures of a Berlin workingman's family, numbering 4 persons, were already fluctuating from 18 to 25 per cent of the total expenditures, and those of a bachelor averaged as high as 28 per cent. ${ }^{10}$

The admirable work of Professor Ashley on The Progress of the German Working Classes will give us the reason for such an extraordinary change. Every side of Germany's economic life is discussed by $\mathrm{Mr}$. Ashley, and they all testify to the gradual but steady improvement of the workingmen. In Krupp's works, for instance, the average wage has risen, between I87I-I900, 57 per cent, while, owing to a special housing policy, rent actually decreased. During the same period the price of bacon increased but 2 per cent, that of beef 1 I per cent, veal 2 I per cent, that of potatoes decreased $3 \mathrm{I}$ per cent, that of bread decreased 27 per cent. ${ }^{11}$ The annual earnings in the Hamburg shipbuilding yards show the following percentage of increase:

\begin{tabular}{lccc} 
& \multicolumn{1}{c}{$1880-1890$} & $1890-1899$ & $1880-1899$ \\
Shipbuilders $\ldots \ldots \ldots \ldots$ & 7.2 & 13.5 & 21.7 \\
Machinists $\ldots \ldots \ldots \ldots \ldots$ & 19.4 & 13.3 & 35.3 \\
Helpers $\ldots \ldots \ldots \ldots \ldots$ & 30.4 & 14.5 & 49.3 \\
Boilermakers $\ldots \ldots \ldots \ldots \ldots$ & 28.00 & 13.0 & 44.7
\end{tabular}

10 SoLNCEv, op. cit., p. 38.

11 W. J. Asmuey, The Progress of the German Working Classes in the Last Quarter of a Century. 1904, p. 9I. 
And this general rise took place in spite of the introduction of the ten-hour day in the middle of the eighties. ${ }^{12}$ The approximate average wage of the coal heavers in Westphalia was in

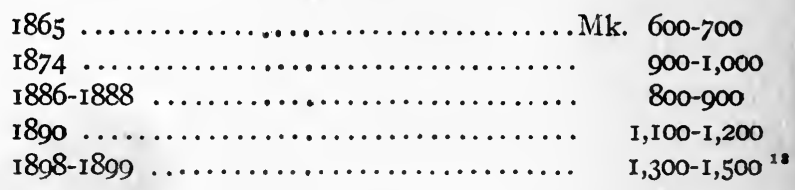

The deposits in savings banks in Saxony increased from Mk. I 14.65 per head of the population in 1880 to Mk. 222.03 in $1900 .{ }^{14}$ In Prussia the number of savings bank depositors in 1875 was 2,209 , IOI, the amount deposited I, I I 2 millions; in $1898,8,049,599$ depositors and the amount deposited 5,287 millions. ${ }^{15}$ The consumption of all ordinary articles of food increased greatly during the same period throughout Germany. The consumption of wheat rose from $5^{1.6}$ kilos per head in $1879-84$ to 74.4 kilos in $1895-96$, that of sugar from 6.4 kilos in $187 \mathrm{I}-8 \mathrm{I}$ to 10.7 kilos in $189 \mathrm{I}-96$, that of rice from $\mathrm{r} .55$ kilos in $187 \mathrm{I}-75$ to 2.49 kilos in 189I-95, of petroleum $\mathrm{r} .87$ kilos in I886-90 to 16.14 kilos in $1896 .^{16}$ The consumption of meat increased in Prussia from 18 kilos per head in 1867 to 37 kilos in 1897 ; in Saxony the consumption of beef and pork increased from 22.2 kilos in 1860

12 Ibid., p. 93.
${ }^{13}$ Ibid., p. 95.

14 Ibid., p. 116.

${ }^{15}$ Ibid., p. 117.

${ }^{16}$ Ibid., pp. 120-122. 
to 43.1 kilos in 1900 . The death rate decreased from 29.0 per 1,000 in 1870 to 20.6 in $1902,{ }^{17}$ the death rate in Berlin from 31.89 in $1861-70$ to 17.38 in 1903 ; the number of suicides decreased from $3^{1}$ per 100,000 in 187I-8I to 24.5 in $1897-1901 ;^{18}$ the over-sea emigration decreased from 3.22 per cent of the population in 1884 to 0.40 per cent in 1900 . The number of overcrowded dwellings in Berlin with one heated room decreased from 195.5 per 1,000 in 1875 to 132.2 in 1895; with two heated rooms from 20.7 per 1,000 in 1875 to 10.9 in 1895 ; in Frankfort, the number of overcrowded dwellings with one heated room was, in 1885, 127.7 per 1,000, in 1895, 43; overcrowded dwellings with two heated rooms in $1885,20.3$ per 1,000 , in $1895,7.8$.

So much for the "increasing misery" in Germany. Now let us turn to England.

Sir Robert Giffen in The Progress of the Working Classes in the Last Half Century gives us some extremely interesting data on the subject, which we shall take the liberty of quoting. Giffen's tables are somewhat antiquated, but still interesting and instructive enough for our purposes. They were compiled about $1882 .^{19}$

17 Ibid., p. I30.

10 We are quoting from the American edition published by G. P. Putnam's Sons, 1885 , p. 5 . 


\begin{tabular}{|c|c|c|c|c|c|}
\hline OCCUPATION & Place & 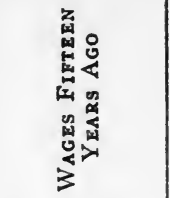 & 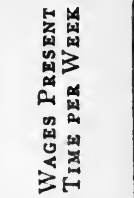 & AMOUNT & 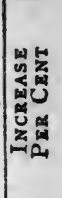 \\
\hline 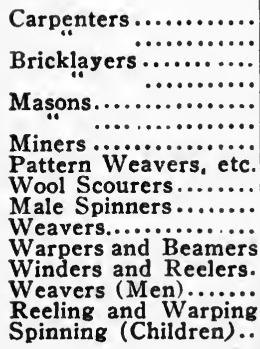 & 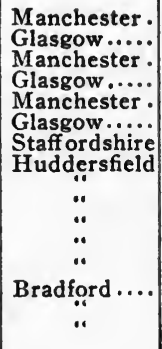 & $\begin{array}{l}24 s . \\
14 s . \\
24 s . \\
15 s . \\
24 s . \\
14 s . \\
2 s .8 \mathrm{~d} \text {. per day } \\
16 \mathrm{~s} . \\
175 . \\
25 \mathrm{~s} .6 \mathrm{~d} . \\
12 \mathrm{~s} . \\
17 \mathrm{~s} . \\
6 \mathrm{~s} . \\
8 \mathrm{~s} .3 \mathrm{~d} . \\
7 \mathrm{~s} .9 \mathrm{~d} . \\
4 \mathrm{~s} .6 \mathrm{~d} .\end{array}$ & $\begin{array}{l}34 s . \\
26 s . \\
36 s . \\
27 s . \\
29 s . \text { Iod. } \\
23 s . \quad 8 d . \\
4 s . \text { per day } \\
25 s . \\
22 s . \\
30 s . \\
26 s . \\
27 s . \\
115 . \\
205.6 \mathrm{~d} . \\
\text { 15s. 6d. } \\
\text { IIs. 6d. }\end{array}$ & 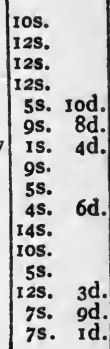 & $\begin{array}{r}42 \\
85 \\
50 \\
80 \\
24 \\
69 \\
50 \\
55 \\
30 \\
20 \\
115 \\
58 \\
83 \\
150 \\
100 \\
160\end{array}$ \\
\hline
\end{tabular}

Sir Robert Giffen's figures were indorsed by Sidney Webb. He writes:

"There seems no reason to doubt, so far as concerns the male worker, the general accuracy of Sir Robert Giffen's conclusion that the rise in nearly all the trades has been from 50 to Ioo per cent. In some of the building trades, for instance, wages have in certain localities actually doubled during the present century. The son of a carpenter in Scotland told me that he remembered his father about 1850 regularly bringing home $34 / 6$ as his wage-not for one, but for four weeks' work, the system of monthly pays not yet having been abolished. It is true that this was in the neighborhood of Inverness, but I mention the incident to recall the fact that wages have often risen 
most in obscure nooks and corners of the land which have been opened up by those great levelers of wages and prices-railways and the postal system. But even in Glasgow the minutes of the energetic Joiners' Union show that it was fighting hard between I8331837 to get a standard rate of $21 /$ per week, as against $36 /$ at the present day, and the stone masons in Glasgow have improved their rate of pay from 5 d per hour in 1853 , which is the earliest year for which I could obtain the figures, to $81 / 2 \mathrm{~d}$ per hour now. And if we turn to quite another industry, $I$ have ascertained the rate of wages of enginemen at a small colliery in the Lothians since the year I83I. They begin at II/ per week, and rise steadily, though with numerous fluctuations, to $23 / 4$ in 1872 , and no less than $33 / 3$ per week in $1892 . " 20$

Of course rent has greatly increased in the last decades. So has meat increased in price, but meat played practically no rôle in the workingman's diet some fifty to sixty years ago. Pork advanced but slightly in price; $8 \mathrm{lbs}$. of pork cost in $18404 \mathrm{~s} .3^{\mathrm{T}} / 2 \mathrm{~d}$., in $188 \mathrm{r} 4 \mathrm{~s}$. $6 \mathrm{~d}$.; on the other hand many foodstuffs have become much cheaper. For instance, the price of 1 cwt. of sugar in $1839-40$ was 68 s. 8 d., in 1882 2Is. 9d.

That the increase in wages signified a tremendous increase in real wages and not in mere money wages,

${ }^{30}$ SIDNey WeBB, Labor in the Longest Reign (1837-1897). London, 1905, p. 4 
is fully demonstrated by the almost incredible growth in England's per capita consumption, which is aiter all in the main workingman's consumption. Here is a table of the quantities of the principal imported and excisable articles retained for home consumption per head of the total population of the United Kingdom:

\begin{tabular}{|c|c|c|}
\hline & 1840 & I88I \\
\hline 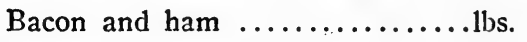 & $0.0 \mathrm{I}$ & 13.93 \\
\hline Butter...$\ldots \ldots \ldots \ldots \ldots \ldots \ldots$ & 1.05 & 6.36 \\
\hline Cheese...$\ldots \ldots \ldots \ldots \ldots \ldots$. & 0.92 & 5.77 \\
\hline Currants and raisins $\ldots \ldots \ldots \ldots \ldots$ " & I. 45 & 4.34 \\
\hline Eggs $\ldots \ldots \ldots \ldots \ldots \ldots \ldots \ldots$ No. & 3.63 & 21.65 \\
\hline 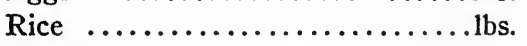 & 0.90 & 16.32 \\
\hline Cocoa...$\ldots \ldots \ldots \ldots \ldots \ldots \ldots \ldots$ " & 0.08 & 0.89 \\
\hline Corn, wheat and wheat flour .... “ & 42.47 & 216.92 \\
\hline Raw sugar $\ldots \ldots \ldots \ldots \ldots \ldots \ldots$. & 15.20 & 58.92 \\
\hline Refined sugar $\therefore . . \ldots \ldots \ldots \ldots \ldots$ " & nil & 8.44 \\
\hline Tea $\ldots \ldots \ldots \ldots \ldots \ldots \ldots \ldots \ldots \ldots$ " & 1.22 & 4.58 \\
\hline Tobacco ................... & 0.86 & I.41 \\
\hline Wine...$\ldots \ldots \ldots \ldots \ldots \ldots$. & 0.25 & 0.45 \\
\hline Spirits $\ldots . \ldots \ldots \ldots \ldots \ldots \ldots \ldots$ & 0.97 & 1.08 \\
\hline Malt $\ldots \ldots \ldots \ldots \ldots \ldots \ldots \ldots \ldots \ldots$ “ & 1.59 & I.91 \\
\hline
\end{tabular}

Giffen is certainly right in calling these figures "wonderful." 21 And everybody must agree with him that such figures are the best evidence of diffused material well-being among the masses.

But progress did not stop with the date of Giffen's investigation. Bowley's figures begin just where Giffen's stop, namely in 1882 . Here are the conclusions of England's best statistician: ${ }^{22}$

"Giffen, loc. cit., p. 20.

22 A. L. Bowley, Statistical Studies: relating to National Progress in Wealth and Trade since 1882. London, 1904, p. 32. 
Average money wages, $1883-87$, taken for roo.............. Average prices, ditto............ Average money income per head of the population, ditto.

Consumption of commodities, ditto $\ldots \ldots \ldots \ldots \ldots \ldots . . . . . .$.

Percentage out of work.......

Number of adult male paupers per 1,000 adult males......... Number of adult female paupers per 1,000 adult females. .

\begin{tabular}{|c|c|c|c}
$188_{3}-1887$ & $1888-1892$ & $1893-1897$ & $1898-1902$ \\
\hline & & & \\
100 & 110 & 115 & 130 \\
100 & 95 & 90 & 92 \\
100 & 113 & 108 & 120 \\
100 & 108 & 112 & 120 \\
7.2 & 3.8 & 5.4 & 3.5 \\
35 & 33 & 38 & 31 \\
42 & 36 & 35 & 29 \\
\hline
\end{tabular}

The average real wages (that is wages, expressed not in money, but in goods that can be purchased by them) in the United Kingdom Bowley expresses as follows, in percentages of the level of 1900 :

Years ........ 1830, '40, '50, '60, '70, '75, '80, '85, '90, '95, 1900 $\begin{array}{llllllllllll}\text { Real Wages } \ldots . . & 45 & 50 & 50 & 55 & 60 & 70 & 70 & 72 & 84 & 93 & 100\end{array}$ and Bowley adds: "If this table is studied, it will be found that the rate of increase in the last twenty years has been greater than in any previous period of equal length." 23

I will not burden the reader with any further data relating to the steady increase of well-being of the English laboring class, although we could easily fill a volume with such figures. We refer the more inquisitive to the Journal of the Royal Statistical Society, where they will find the information in Bowley's admirable articles.

23 BowLEY, loc. cit., p. 33. 
We could not well close without reference to the United States. The opinion is widespread that decades ago the laborer found here a country flowing with milk and honey, but that since capitalism on a large scale has developed, conditions have changed for the worse, and that, historically considered, the situation of the working classes in America has deteriorated rather than improved.

It does not seem to us that such a view can be supported by facts; the economist will certainly tend to indorse the conclusions at which a man like Levasseur arrived. In his L'ouvrier américain Levasseur writes: "In the Population Française I said, speaking of wages: "The doubling of wages in France in the last sixty years is an average estimate based upon figures which we have collected, and which we believe to be correct. Like most averages, however, it may be disputed. It is not difficult to find conflicting instances here and there. . . But the divergence of extremes does not invalidate a mean when the latter is based upon a majority of returns.' And what I have said in speaking of the greater part of the states of Europe I now reaffirm in speaking of the United States." ${ }^{24}$

There is no doubt whatsoever that the occupation and exploitation of a new continent, a process which has not yet come to a close, offered an unprecedented.

24 E. Levasseur, The American Workman. English translation by T. S. Adams. Baltimore, 1900, pp. 287, 288. 
spectacle. Res mullius cedit primo occupanti. The natural resources which were nobody's were becoming somebody's, millions of prosperous homes were built on the land which the sturdy pioneers of American civilization had conquered. The reward of the most enterprising and successful was wealth never known of nor heard of in the past. Many, if not the majority, of the employers of to-day began as wageearners themselves. But those that have graduated from the laboring class we are not considering here; the masses that at the given time constituted and now constitute the laboring class, form the object of our inquiry. Does or does not the condition of the working class in America justify the doctrine of increasing misery?-this is the question before us.

Some very interesting early statistical material was gathered by the late Carroll D. Wright, while chief of the Massachusetts Bureau of Statistics of Labor. ${ }^{25}$ These data, which are about as reliable as any early statistics can be, show conclusively how much as a rule we exaggerate the good old times. Scarce as labor was at the dawn of American civilization, those whom circumstances compelled to be laborers received very meager pay. In Massachusetts in I633 or thereabouts the wages of a master carpenter and master mason were about 33 cents a day; of master tailors 27 cents per day. ${ }^{28}$ The average price of a bushel of barley

${ }^{28}$ Mass. Bureau of Statistics of Labor, Sixteenth Annual Report, Boston, 1885.

20 Ibid., p. 429. 
was then 67 cents, of corn 48 cents, of wheat 8I cents; a pair of men's shoes were worth in 1672 about 83 cents. "A skilled laborer made in a week's work only enough," writes T. S. Adams, " to buy about four bushels of corn, between three and four bushels of peas, or between two and three bushels of wheat. Two and a half days' work was required to earn enough to buy a pair of rough shoes." ${ }^{27}$ The wages towards the end of the seventeenth century show no substantial change. The wages of the middle of the eighteenth century begin to show an increase, and they progress steadily from that time on. In Carroll D. Wright's report of 1885 we find the following data ${ }^{28}$ for the daily wage. The agricultural laborers received in 1760 about 3 I cents, in 1800 about 47 cents, 1830 about 80 , I860, \$1.00, I880, \$I.3I; blacksmiths in I790, 69 cents, in I820, 84 cents, I830, \$1.12, I860, \$1.69, I880, $\$ 2.28$; carpenters I780, 52 cents, I830, $\$ 1.07$, I86o, \$2.03, I880, \$2.42; common laborers I780, 37 cents, 1800,62 cents, I830, 79 cents, I860, 97 cents, I880, \$I.48; machinists I840, \$I.35, I850, \$I.62, I860, \$2.1 5, I88o, \$2.49; masons I 780, 66 cents, 1830, \$1.22, I860, $\$ 1.53$, I880, $\$ 2.79$; the wages of other occupations advanced in the same proportion. "Consolidating and averaging the wages, . . . the general aver-

${ }^{27}$ Adams and Sumner, Labor Problems, 3d ed., New York, 1905, p. 505.

${ }^{28}$ Mass. Bureau of Statistics of Labor, Sixteenth Annual Report, Boston, 1885, pp. 454, 455 . 
age increase in wages shown for the decade ending with 1860 as compared with that ending with 1830 is 52.3 per cent." This is Colonel Wright's conclusion. ${ }^{29}$ Consolidating the prices of various types of articles of consumption during the same period, "the general average percentage of increase in prices is found to be 9.6 per cent," ${ }^{30}$ figures sufficiently indicative of the improved financial condition of the workingman.

In an elaborate review of wages and prices of the period between I860-I878 Carroll D. Wright comes further to the conclusion that the ascertained relations of wages and prices show " in 1878 an advance over 1860 of twenty-four and four-tenths per cent in average weekly wages, and an average advance in cost of living of fourteen and a half per cent, which means a pecuniary betterment of ten per cent in the general condition of the workingman in Massachusetts in 1878 as compared with 1860 , no account being made of the decrease in the hours of labor in many industries." 31

The recent industrial development records an even more substantial increase. Taking the year 1890 for 100 as a standard year, wages show the following average rise throughout the United States in industry and agriculture:

20 Mass. Bureau of Statistics of Labor, Sixteenth Annual Report, Boston, 1885, p. 466.

${ }^{80}$ Ibid., p. 467.

"Mass. Bureau of Statistics of Labor, Tenth Annual Report, p. 95. 


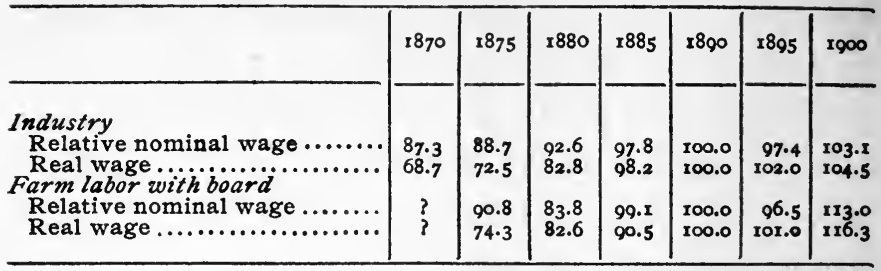

This is an abbreviation of Adams and Sumner's table, ${ }^{32}$ in explanation of which Adams writes: "The year I866 ushered in a new epoch, during which, it is no exaggeration to say, the American workingman advanced in a manner unprecedented in this country in which steady progress has been the rule since the establishment of the Union." 33

We regard it as superfluous seriously to argue further on the subject of the increasing misery of the American workingman. Those interested in the rise of American wages will find all the details in the Census reports, in the Aldrich Report (especially in parts III and IV) and in the Bulletins of the Bureau of Labor ${ }^{34}$ in these pages we do not feel at liberty to tax the patience of the reader with further statistical data.

We trust it is evident that the experience of all

${ }^{82}$ Adams and Sumner, loc. cit., p. 514.

${ }^{38}$ Ibid., p. 5 II.

${ }^{34}$ Especially in Bulletin 77, Wages and Hours of Labor, 18901907, and Retail Prices of Goods, I890-1907. We call particular attention to the tables on pp. 4 and 1o. Interesting also is the budget material in Bulletin 54, particularly the tables on pp. I133 and 1147 . 
industrial countries without exception shows a steady and unprecedented improvement in the conditions of the working class. The tendency which was to lead to a breakdown of our economic organization not only broke down itself, but developed a counter-tendency in exactly the opposite direction.

Yet what is the attitude of the theoretical leaders of so-called scientific socialism? They lack the good sense to acknowledge the facts, and are hedging behind subterfuges and interpretations which, while seemingly exonerating Marx on one point, reduce him to the level of a nonentity on all points, and they end up by hurling in defiance another prophecy: "Until a great world-change takes place the proletariat must reckon with the fact that the good times are over and that the regular increase in real wages has reached its end." 35 And we often find expressed the fear, and half-expressed the doctrinaire hope, that technical developments, changes in the world market or in the political situation, may start the long-expected downward tendency. The rôle of the orthodox socialist in the whole matter is well characterized in what our lovable essayist, Samuel Crothers, has to say about Jonah.

"Jonah was a prophet by profession. He received a call to preach in the city of Nineveh, which he accepted after some hesitation. He denounced civic cor-

"3 Karl Kautsky, "Must the Proletariat Degenerate?", The International Socialist Review, February, 1909, p. 580. 
ruption and declared that in forty days the city would be destroyed. Having performed this professional duty, Jonah felt that there was nothing left for him but to await with pious resignation the fulfilment of his prophecy. But in this case the unexpected happened, the city repented and was saved. This was gall and wormwood to Jonah. His orderly mind was offended by the disarrangement in his schedule. What was the use of being a prophet if things did not turn out as he said? So we are told 'it displeased Jonah exceedingly, and he was angry.' Still he clung to his hope that, in the end, things might turn out badly enough to justify his public utterances." 36

30 S. M. CRothers, By the Christmas Fire, Boston, 1908, pp. 58,59 . 


\section{CHAPTER VIII}

\section{CLASS-STRUGGLE CONCEPTIONS. FORE- RUNNERS OF MARX}

All the doctrines of Karl Marx, scattered as they are in various writings, support one another and thus form a single theoretical system. We find, accordingly, that all the theses of Marx which we have examined in the preceding parts of this study lead up to his class-struggle doctrine. It is on the basis of his economic interpretation of history that he constructs his theory of the development of social life. Division of labor produces a division of classes, with the lower class in constant struggle against the upper class. The concentration of industry leads to a concentration of capital, which, while gradually narrowing the capitalist class to a small circle of financial and industrial magnates, pushes the middle classartisans, shop-keepers and farmers-into the ranks of wage-earners. The continuous development and frequent revolution of technique make production more and more independent of the workingman's skill and physical strength. Improved machinery displaces labor and makes it possible to substitute unskilled for skilled labor, child labor for adult labor. These 
changes increase the reserve army of the unemployed and make the living conditions of the employed more and more precarious. The growing misery of the working class increasingly accentuates and embitters the raging class struggle.

Of all the doctrines of Marx no one perhaps grates so much upon American feeling as his doctrine of class struggle. All that is broadly American-the memory of the past, the theory of government, the democratic ideal and the energetic personal outlookseems to rebel against such an interpretation of society. Yet this is a conception which permeates the whole Marxian system. All the doctrines which we have thus far examined are from a certain viewpoint but scaffoldings for the class-struggle doctrine. We must therefore endeavor to understand and criticise this doctrine despite disinclination and apart from preconception.

It will be well to begin our analysis of the classstruggle theory with an historical excursion, for this may prove helpful when we are called upon to determine what is true and what is erroneous in the Marxian doctrine. Some years ago a Russian anarchist, W. Tcherkesoff, ${ }^{1}$ attacked the Communist Manifesto of Marx and Engels as a plagiarism from a pamphlet of Considérant. ${ }^{2}$ No attention was paid by the so-

${ }^{2}$ Pages of Socialist History (New York, C. B. Cooper, 114 Fourth Ave., 1902), pp. 55-66.

? Victor ConsIdérant, Principes du socialisme: Manifeste de 
cialist writers to this pamphlet until the Italian scholar Labriola stated, in practical agreement with Tcherkesoff, that the main ideas of the Communist Manifesto, such as the concentration of industry and of capital and the increasing misery of the masses, are contained in the pamphlet of Considérant. It was no great discovery that Tcherkesoff and Labriola made. A more intimate acquaintance with French literature would have shown them that these were current conceptions, to be found in Vidal as in Pecqueur, in Considérant as in Louis Blanc-conceptions suggested by the hopeless economic conditions which followed in the wake of the industrial revolution, and probably first formulated by the great French economic thinker, Simonde de Sismondi. ${ }^{3}$

To the accusation of plagiarism directed against Marx, Kautsky replied that, so far as the theories of

la démocratie au dix-neuvième siècle (Ist ed., Paris, 1843 ; 2d ed., Paris, 1847). I have not seen this pamphlet, and my acquaintance with it is limited to Tcherkesoff's, Labriola's and Kautsky's citations.

- Nearly all the "new ideas" are to be found in Sismondi, not excluding the very latest attempt of Kautsky to save Marx's theory of increasing misery by reinterpreting it violently in the sense of an increasing relative disproportion in wealth: "Thus the progress of industry, the progress of production ... tends to increase inequality among men. The more advanced a nation is in the arts and manufactures, the greater is the difference between the fate of those who work and that of those who enjoy; the more misery the former suffer, the more luxury the latter display." DE Sismondr, Nouveaux principes d'économie politique ou de la richesse dans ses rapports avec la population (2d ed., Paris, 1827), vol. i, p. 80. 
concentration of wealth and of increasing misery are concerned, it is quite true that a number of socialist writers of the forties held similar views; but that what distinguishes Marx from all others is his insight into "the rôle of class struggle as the driving force in social development." While other socialists-in particular, the school of Fourier and Considérantsaw in increasing misery nothing but unmitigated misery, Marx saw in the same phenomenon the pledge of the inevitable struggle, the assurance of the coming victory. ${ }^{4}$

4"Had Marx and Engels asserted that the socialism of the nineteenth century began with the Communist Manifesto, they would certainly have been plagiarists. Only one who was familiar with Considérant alone of the other socialists of the time could maintain that they had transcribed from him in particular, for what the Communist Manifesto had in common with Considérant's manifesto it shared with the theories of all other contemporary socialists.

"But wherein consists the particular merit of the Communist Manifesto if the so-called 'theories of increasing misery and concentration of capital' were acknowledged by the other socialists of their time, if they all based their socialism upon the economic tendencies of the capitalist mode of production?

"This merit consisted first of all in the fact that these theories appeared more clear-cut in the Manifesto than in any other socialist publication of their time; and secondly in the conception of the rôle of class struggle as the driving force in social development, and in the application of this conception to the proletarian struggle. Of this the majority of the other socialists had absolutely no idea, and especially in that group to which Considérant belonged the class struggle was considered a most deplorable error. To be sure, both Considérant and his associates acknowledged the existence of the class struggle, but they did not see how inevitably it grew out of the economic development, and 
I cannot quite share Kautsky's viewpoint. What strikes me as new and characteristic in Marx is his effort to maintain a consistent historical realism and his systematic coördination of ideas which, regarded singly, were not original. Engels himself seemed to exaggerate the originality of the class-struggle conception in the Communist Manifesto. ${ }^{5}$ The antagonism between poor and rich was a commonplace observation, even in the days of classical antiquity; and the earliest socialist writers did not fail to take notice of this antagonism. Saint-Simon plainly speaks of the "proletarian class," describes existing law, particularly the law of inheritance, as "the daughter of the right of conquest," and shows how the many are exploited by the few, the latter enjoying a legal " monopoly of all riches." " Saint-Simon, indeed, lays

prepared the way for the new order of things." K. KauTSKY, "Das Kommunistische Manifest ein Plagiat," Neue Zeit (Jahrg. XXIV, 1906), vol. xi, p. 698.

- If Herr Duehring means . . . that our present economic condition, the stage attained to-day in agriculture and industry, is the result of a society which has developed itself in class antagonisms, in mastership on the one hand and in slavery on the other hand, he says something which is a mere commonplace since the publication of the Communist Manifesto." FREDERICK Engers, Landmarks of Scientific Socialism (Anti-Duehring), translated by Austin Lewis (Chicago, 1907), p. 206.

- "The advantages and disadvantages of each position in the social scale are handed down by heredity; the economists have taken pains to verify one of the aspects of this fact, the inheritance of poverty, since they have recognized the existence in society of a proletarian class. To-day the whole working population is exploited by the men whose property they make use 
chief stress on class exploitation, although to him, apparently, class antagonism and class exploitation are identical conceptions. Moreover he points out that the degree of exploitation of one class by another has in the course of centuries greatly diminished. ${ }^{7}$

But Marx was not lacking in predecessors whose class-struggle conception was sharply defined. French nineteenth-century historians needed no enlightenment on this point in dealing with the events which led up to and followed the French Revolution. ${ }^{8}$ By far the most interesting of these writers was Guizot, who was not only a great historian but a great of ; the captains of industry themselves submit to this exploitation in their relations with the capitalists, but to an incomparably lesser degree; and in turn they participate in the privileges of the exploitation, which falls back with all its weight on the working class, that is, on the immense majority of the workers. In such a state of affairs, the workingman appears as the direct descendant of the slave and the serf; he has personal liberty, he is no longer bound to the soil, but that is all he has attained, and, in this state of legal enfranchisement, he can live only under conditions imposed on him by a small class-that of men whom a law, daughter of the right of conquest, invests with the monopoly of all riches, that is, the power to dispose at will, and even in idleness, of the instruments of production." SaINTSimon et Enfentin, Euvres, vol. xli, pp. 225, 226.

" "Antagonism, the rule of force, the exploitation of man by man, are to-day without doubt greatly diminished; they no longer manifest themselves except under forms so softened and tame that it seems difficult at first to appreciate their importance; nevertheless they continue to exist under these forms and their potency is still great." SaInt-Simon, loc. cit., p. 222.

- This subject is adequately dealt with by Plekhanoff in his preface to the Russian edition of the Communist Manifesto (Geneva, 1900), pp. 14 et seq. 
statesman, and who, curiously enough, was responsible for exiling Marx from Paris for views which he himself, even if indirectly, helped to formulate. Guizot was a thinker and writer of unflinching courage, confessedly the spokesman of the bourgeoisie and proud of this rôle. To the defense of the new order of things, as constituted after the Revolution, he devoted his life. As a statesman, he regarded the middle class as the foundation of the société nouvelle, and, as an historian, he glorified its deeds and struggles in past centuries. ${ }^{\circ}$ During his prime there was not a shred of sentimentality about him; he used his own clear head and nobody's obscure philosophy; and the only respect in which Marx's class-struggle conception can be regarded as an advance over Guizot's is that Marx interpreted economically the formation, division, antagonism and struggle of classes-an explanation which is lacking in Guizot. On the other hand Guizot makes, as early as 1816 , some truly amazing statements. The theorists of the Revolution, according to him, either deceived themselves or were lying when they talked about the sovereignty of the people. It was not a question of sovereignty but of

- "I zealously uphold the new social order as constituted by the revolution, which has equality before the law as its first principle and the middle classes as its foundation. I glorify again this cause which is already so glorious by tracing it back into the past and discovering its interests and vicissitudes in the whole course of our history." Guizor, Mémoires pour servir d l'histoire de mon temps (Paris, 1858), vol. i, p. 296. 
the conquest of one portion of the people by another. ${ }^{10}$ The victorious portion comprised an immense majority, and the doctrine of the sovereignty of the people added to their force. We seem always to need a doctrine, even if we have superior force on our side, simply because we love to believe and make others believe that we are right. ${ }^{11}$ That is an interpretation of the origin and value of political doctrines sufficiently pragmatic even for our day!

To Guizot, French history is a record of a struggle between two classes, which lasted for thirteen centuries, and of which the final act was the Revolution. ${ }^{12}$ The Revolution itself was the hour of triumph and of vengeance of the oppressed class; and whoever fails to view it in this aspect, as a class struggle, will never

${ }^{10}$ This was to such an extent a matter of fact that the theorists of the Revolution became unconscious of it when they were talking theory; but their language was quite different when they were making practical propositions. So St. Just suggests: "The way to strengthen the revolution is to make it profitable to those who support it and ruinous to those who oppose it." Suite de la copie de pièces saisies dans le local que Babeuf occupait lors de son arrestation (Paris, Nivôse, An V), vol. ii, p. 72 .

${ }^{11}$ Guizor, Du gouvernement de la France depuis la restauration et du ministère actuel (3d ed., Paris, 1820), p. I38.

12 "The revolution was a war, a real war, like the wars between foreign peoples with which we are familiar. For thirteen centuries France contained two such peoples, the conqueror and the conquered. For thirteen centuries the conquered people struggled to shake off the yoke of their conqueror. Our history is the history of that struggle. In our day the decisive battle has been fought. It is called the revolution." Ibid., pp. I, 2 . 
comprehend it, will never understand its successes and reverses, its virtues and its crimes. ${ }^{13}$ When attacked on account of his class-struggle conception by the press of his time, Guizot replied that it never occurred to him that he had the honor of making a discovery or even of finding a fresh phrase. People were saying the same thing hundreds of years before the Revolution and three months before he published his book. ${ }^{14}$ What he was stating, Guizot claimed, was neither a theory nor an hypothesis, but a fact in all its simplicity; a fact which it was ridiculous to question; a fact witnessed by the past as well as the present, by the conduct of the kings and the texts of their ordinances as well as by the proceedings of the StatesGeneral, the speeches in the Assembly, the civil code and the latest French constitution. ${ }^{15}$

What is characteristic of all the earlier writings of Guizot is his joy in life and in conflict, his tone of challenge, his contempt for all who hesitated to admit the class struggle. Class struggle, however, meant to him solely the struggle of the bourgeoisie against the feudal aristocracy; the working class was left out of consideration. Later, as the proletariat of Paris made itself felt more and more as a political force, and in proportion to the degree in which it made itself felt, his tone became more subdued, more cautious. In his

1s Ibid., p. 139.

14 Ibid., avant-propos de la troisième édition, p. vi.

28 Ibid., pp. xv, xvi. 
brilliant essay on "Democracy in Modern Communities," published in 1838 , he described democracy as a war-cry, as the banner raised by the many of lower rank against the few placed above them $;^{18}$ the consequences of this war in behalf of democracy were many and they were fruitful: scattered and destroyed were the feudal system, the caste system, the perpetual concentration of social privileges in the hands of the few, the right divine, lay or ecclesiastical; ${ }^{17}$ but the further and continued attack in the name of democracy he already regarded as mischievous and capable of destruction only. Here is his picture of the struggle for democracy:

"Political rights and privileges have been exclusively concentrated in the hands of a small number. This concentration no longer appears justifiable, upon the plea of superiority either in riches, influence, intelligence or moral and social strength. The multitude rises and exclaims: Let us count our numbers; we are all equal; let the power belong to the many.

"It is thus that the new maxims oppose the old; they are true when received in their negative sense and are powerful engines of destruction. The ancient edifice yields to the vigor of their attacks and falls to the ground. This is a fearful but, under the decrees of Providence, a predestined work. When the ancient

18 Gurzot, Democracy in Modern Communities, translated from his essay in the Revue Française (London, 1838), p. 7.

${ }^{27}$ Ibid., p. 16. 
edifice becomes contracted, inconvenient, uninhabitable, ruinous and defended only by a corps of invalids, its fall is inevitable; and the battering ram, the sap and the mine detach it from the soil with a force that threatens even the soil itself. But when the work of destruction is consummated and the hour of reconstruction arrives, when the necessity of it is universally admitted, when it is commenced spontaneously in all directions, what can be more absurd, what more mischievous, than to continue still sounding the attack and directing against the rising edifice, to the peril of its artificers, the very engines which subverted the old one." 18

His experience as a prime-minister during the Revolution of 1848 made him cry out for social peace and denounce the new class struggle as the greatest shame of the century. ${ }^{19}$ But he himself realized that his was but a pious wish and his voice that of one crying in

${ }^{18}$ Ibid., p. 45.

10 "The struggle between the different classes of our society fills our history. Nobility and third estate, aristocracy and democracy, bourgeoisie and workingmen, property owners and proletarians,-so many forms for so many different phases of the social struggle which has so long tormented us. And it is at the very time when we boast of having reached the apogee of civilization, it is to the sound of the most humane utterances that can pass the lips of men, that this struggle breaks out again more violent, more furious than ever! It is a scourge, a shame that our age cannot endure. Internal peace, peace between all classes of citizens, social peace! that is what France most desperately needs, that is our cry for help." Guizor, De la $D_{\dot{e} \text { - }}$ mocratie en France (Paris, 1849), p. 35. 
the wilderness. He saw that the new combatant class that had entered the arena was young and strong and as arrogant as nobility or bourgeoisie had ever dared to be, and that the outlook for social peace was dark indeed. ${ }^{20}$ He realized also that the very meaning of the word democracy had changed, shifted, where he could not follow it: it had begun to mean real democracy or, as he called it, pure and absolute democracy, and this new watchword foreboded new and incessant struggles. ${ }^{21}$

It could hardly be denied that Guizot had a clear-cut conception of class struggle, not only as an empirical fact but as an historical force, indeed as the social force which is ultimately responsible for the great

20 "And now a third combatant has entered the arena. The democratic element is divided. Against the middle classes are ranged the working classes, against the bourgeoisie the common people. Moreover this new war is a war to the death, for the new combatant is arrogant, exclusive, as no other class ever was. Only the people, they say, have a right to sovereignty; and no rival, old or new, noble or bourgeois, can be admitted to share it with him." Ibid., p. 107.

21 " The socialists, the communists, the montagnards want the republic to be a democracy pure and absolute. On this condition alone is the republic justifiable in their eyes. Such is the sway of the word democracy that no government, no party, dares to live, or thinks it can live, without inscribing this word on its standard; and those who carry this standard highest and farthest believe themselves to be the strongest. Fatal notion, which incessantly stirs up war in our midst, social war! We must extirpate this notion. This is the price of social peace, and with social peace, liberty, security, prosperity, dignity, all the moral and material blessings that peace alone can insure." Ibid., pp. IO, II. 
changes and readjustments that have taken place in the course of centuries. The actual existing interests accept or reject, discard or change, not only ideas and doctrines but even constitutions ; ${ }^{22}$ all these either serve the interests of the ruling class or express a compromise between the interests of the contending classes, perhaps in accordance with the time-honored recipe: unusquisque tantum iuris habet, quantum potentia valet. And yet Guizot was as right as he was modest when he said that he had made no new discoveries and no new statements. One hundred years earlier very much the same conception of politics had been held by Abbé Baudeau: "Connaître ses intérêts et $y$ pourvoir c'est ce qu'on appelle politique"; and many of Guizot's predecessors were much keener in distinguishing the interests of the working class from that of the tiers état-a distinction which Guizot was very unwillingly compelled to make, and only by the events of the forties.

No revolutionary socialist of our day, no agitator of the Marxian era, has ever surpassed Linguet in branding the class character of all existing legislation. According to Linguet the very essence of all law is to safeguard property and preserve inequality, to protect the rich from the poor; to him it is a demonstrated fact

22 "So true is it that ideas, doctrines, constitutions themselves submit to the yoke of circumstance, and are accepted by the people only when they serve as an instrument or a safeguard for interests which are insistent and generally adhered to." Guizor, Du gouvernement de la France, p. 9I. 
that all existing law is but a formal conspiracy against the vast majority of mankind. Dictated by wealth, the law primarily serves wealth; law is wealth's fortress in the enemy's country. ${ }^{23}$ There is an abyss between those that have and those that have not property. The necessity of living compels the latter to slave for the former; to work on the fields, the fruits of which they will not gather; to erect buildings, in which they will not dwell; and to beg on their knees for permission to enrich the rich. $^{24}$ And that was written in 1767 !

During the French Revolution the socialistic group comprehended without explanation that society as constituted was divided into two classes. If they did not dwell much on the subject, it is because they took

28 "It is above all this inequality whose effects the laws seek to counterbalance, whose dangers they seek to mitigate. They cannot efface it. On the contrary, it is of their very essence to strengthen it. They are designed primarily to insure property rights. Further, as one can take more from a man of means than from one who is destitute, they are cvidently a safeguard provided to protect the rich against the poor. It is hard to believe, and yet it is fully demonstrated, that they are in a sense a conspiracy against the majority of mankind. It is against those who most need their support that their greatest force is directed. It is wealth that prescribes them, and again it is wealth that reaps the principal advantages from them. They are fortresses established in the interest of wealth in the midst of the enemy's country, where wealth alone has dangers to fear." LINGUET, Théorie des lois civiles, ou principes fundamentaux de la société (Londres [Paris], 1767), vol. i, pp. 195, 196.

"Ibid., vol. i, p. 274. 
it for granted: class rule was the main objective of their attack. Their struggle, of course, was all for equality and " nature" against class rule. The very naive opening passages of Buonarroti's History of Babeuf's Conspiracy are convincing on this point. "Whilst ambition, jealousy, cupidity and the blind love of innovation kept up a deplorable struggle among a people of whom some strove to reëstablish the ancient monarchy, others to place upon the French throne a new dynasty, others again to transfer power from one caste of society to another, but all for the purpose of appropriating exclusively to themselves the national authority and thereby those enjoyments of which authority is the source; amid all these parties there was slowly formed a certain class of citizens, who, actuated by very different principles [etc., etc.] . . . Our divisions during the Revolution were the results of opposing interests and principles. While one set of persons (the honest) supported a system because they believed it to be good, another set, far more numerous, united themselves to the party that appeared most favorable to their personal views of fortune and ambition." 28 Of course Babeuf and his followers regarded their own conspiracy not as in the interest of a class but as inspired by eternal justice and " nature"; yet when we read their propaganda songs we find that they

"Buonarroti's History of Babeuf's Conspiracy for Equality, translated by Bronterre (London, 1836), pp. 5, 6. 
apparently address their appeal to a very distinct class. One of these songs describes the "peuple" as robbed by the rich of every right. ${ }^{28}$ The complaint of another song is that " on vit des princes, des sujets, des opulents, des misérables; on vit des maitres, des valets," etc. ${ }^{27}$ Babeuf asserted on one occasion that the French Revolution was a war between patricians and plebeians, between the rich and the poor. And he prophesied that the Revolution could not end so long as the rich had all the privileges and governed the state, while the poor worked like slaves without playing any rôle in the commonwealth. ${ }^{28}$

Thus we see that Marx was not obliged to invent either class hatred or class struggle. Europe had always had plenty of it, and at the beginning of the nineteenth century the outlook for peace was unpromising. The two great poets of Marx's own fatherland expected little from the nineteenth century in the way of peace. Schiller greeted none too optimistically the advent of the new century:

20 "Dying of hunger, dying of cold, people robbed of every right, numbly you mourn your fate; while the brazen rich man, whom your kindness spared in former times, openly rejoices. Upstarts, gorged with gold, without trouble or care or work, seize the hive; and as for you, poor toiling people, eat and digest, if you can, iron, like the ostrich." Suite de la copie de pieces saisis dans le local que Babeuf occupait lors de son arrestation (Paris, An V), vol. ii, pp. 78, 79.

${ }^{27}$ Espinas, La philosophie sociale du XVIIIème siècle et la Révolution (Paris, 1898), p. 248.

"s Fournik̇e, Les théories socialistes au XIXème siècle, p. 355. 
" Das Jahrhundert ist in Sturm geschieden

Und das neue öffnet sich mit Mord." 20

And it is interesting to note that Goethe looked across the sea for social peace, to the new world, which had not inherited feudal castles and traditions of class hatred:

"Amerika, du hast es besser;

Du hast im Magen keine Schlösser;

Dich stört nicht im Innern

$Z u$ lebendiger Zeit

Unnützes Erinnern

Und vergeblicher Streit." 30

But at the very same time there lived in America a statesman who did not seem to have any such poetical illusions about his own country. Madison seemed to think that, with or without castles, different economic interests were sure to produce contending classes; and how to check future class struggles and minimize their effects was the problem which he was endeavoring to solve. In the tenth number of the Federalist we can find the better part of the Marxian doctrine which we are now considering. Madison reasons: "From the protection of different and unequal faculties of ac-

"O "The century has ended in storm, and the new one begins with murder."

"O "America, your lot is happier; you have no fetters to bind you; useless recollections and unnecessary strife do not perpetually disturb you." 
quiring property, the possession of different degrees and kinds of property immediately results; and from the influence of these on the sentiments and views of the respective proprietors, ensues a division of the society into different interests and parties. . . . Those who hold and those who are without property have ever formed distinct interests in society. Those who are creditors and those who are debtors fall under a like discrimination. A landed interest, a manufacturing interest, a mercantile interest, a moneyed interest, with many lesser interests, grow up of necessity in civilized nations, and divide them into different classes actuated by different sentiments and views. . . Either the existence of the same passion or interest in a majority at the same time must be prevented, or the majority, having such coexistent passion or interest, must be rendered, by their number and local situation, unable to concert and carry into effect schemes of oppression. If the impulse and the opportunity be suffered to coincide, we well know that neither moral nor religious motives can be relied on as an adequate control." 32

${ }^{31}$ Speaking of class struggle and its recognition in America, it is worth while to point out that Mr. A. M. Simons, in his work entitled Class Struggles in America (Chicago, 1907), misrepresents John Adams by quoting certain sentences which, separated from the context, suggest ideas quite different from those which Adams was endeavoring to express. On page 14 Mr. Simons cites:

"It is of no consequence by what name you call your people, whether by that of freeman or of slave. In some countries the 
In investigating the extent to which class antagonism was recognized before Marx, it is immaterial whether a particular writer advocated class struggle or discouraged it. The important thing is the consciousness of the existence of classes with antagonistic interests. Even the preaching of class struggle is not necessarily associated with revolutionary tendencies.

laboring men are called freemen, in others they are called slaves, but the difference is imaginary only. What matters it whether a landlord employing ten laborers on his farm gives them annually as much as will buy the necessaries of life or gives them those necessaries at short hand?"

What Adams actually did say Mr. Simons could hardly use in his propaganda pamphlet. The record of Adams's speech is taken from Jefferson's notes, which read as follows: "Mr. John Adams observed, that the numbers of people were taken by this article as an index of the wealth of the state, and not as subjects of taxation; that as to this matter, it was of no consequence by what name you call your people, whether by that of freeman or of slave. In some countries the laboring men are called freemen, in others they are called slaves, but the difference is imaginary only. What matters it whether a landlord employing ten laborers on his farm gives them annually as much as will buy the necessaries of life or gives them those necessaries at short hand? The ten laborers add as much wealth to the state, increase its exports as much, in the one case as in the other. Certainly five hundred freemen produce no more profit, no greater surplus for the payment of taxes, than five hundred slaves. Therefore the state in which the laborers are called freemen should be taxed no more than that in which are those called slaves. . . . A slave may indeed, from custom of speech, be more properly called the wealth of his master, than the free laborer might be called the wealth of his employer; but as to the state, both were equally its wealth and should therefore equally add to the quota of its tax." JоHN Adams, Works, edited by Chas. F. Adams (Boston, 1850), vol. ii, p. 497. 
It has been so, as a rule, when sounded from below; but class struggle has been emphasized from above as an appeal for class rule and class subordination. Ludwig von Haller gives a fair illustration of the latter tendency. His work appeared in 1816 , the year in which Guizot published his Representative Government. The very title is suggestive: Restoration of Political Science (Restauration der Staatswissenschaft). The restoration of the legitimate thrones is to be followed by the reënthronement of legitimate science; the annihilation of the hydra of the Revolution calls for the uprooting of that false political science which is based upon the idea of a social compact. $^{32}$ The substance of this "restored" political science is the right of strength-not physical strength, of course, but the strength of position and of wealth. Instead of the sovereignty of the people, the sovereignty of the one who has the power and the wealth to be independent; instead of authority derived or delegated, one's own might, one's own right-that is the doctrine. ${ }^{33}$ Von Haller saw a miniature prince in every landlord, merchant and manufacturer, because

s2 "The hydra of the Revolution is destroyed as to its tools and largely as to its results; let us also destroy its roots so that it may put forth no new leaves. The legitimate thrones are restored; we wish also to restore that legitimate science which serves the Lord, to the truth of which all creation bears witness." Karl Ludwig voN Haller, Restauration der Staatswissenschaft oder Theorie des natïrlich-geselligen Zustandes (2d ed., 1820 ), vol. i, p. I.

ss Ibid., vol. i, p. xlix. 
these had subordinates. ${ }^{34}$ Such persons fell short of being real princes only in that they were without complete personal independence. ${ }^{35}$ All superiority of power or wealth, he claimed, is a blessing from heaven. ${ }^{38}$ And whosoever is really against revolution, must not only talk against it (even a Jacobin could by mere talk pretend to be against revolution) but must in all his acts do the exact opposite of what the furies of revolution command; he must recognize that all authority is from God, and that God has established inequality in personal fortune to the end that there may be great and small, high and low, etc. ${ }^{37}$

To an American reader the theory of von Haller may seem to be simply a curiosity. In certain purely

"* "In every landlord as well as in every merchant or manufacturer I saw the image of a prince, in an aggregation of subordinates the source, the legal foundation, as well as the limitation, of dependence and servitude." Ibid., vol. i, p. xvi.

sIbid., vol. i, p. xvii.

"Ibid., p. Ixxix.

"7t "Therefore, procure assistance; pray the Lord to send laborers to his vineyard. You will recognize their fitness not because they decry revolution and Jacobinism (for that even its adherents can do effectually enough with ill-concealed hypocrisy), but rather because they do and promote the very opposite of everything which those furies command; because they believe and recognize that all might and all authority are derived from God alone; that he made great and small, high and low, through the diversity of their fortunes; . . . because they leave to each one his own possessions, and do not wish to regulate the relations, the condition, and the possessions of mankind according to their own will. Whoever, on the other hand, regards the authority of the mighty as derived from and granted by the weak, . . of him beware." Ibid., p. Ixxxi. 
philosophical aspects this may be true, but Haller's religious argument for class rule was the argument most generally approved and employed throughout the continent of Europe. That is the reason why a strong anti-religious movement, in fact a militant atheism of one kind or another, was the inevitable precursor of the revolutionary movements in France, Germany and Russia. To meet the mediæval attitude of the established church, whether Catholic, Lutheran or Greek, incipient revolution invariably started with a general attack upon religion as such, an attack which seemingly obscured all political issues. To Americans, whose churches, fortunately, have developed under democratic auspices, the psychology of such movements must appear strange and almost incomprehensible. And yet without a clear understanding of this revolutionary psychology the sweeping conquest which Marx's class-struggle doctrine has achieved will remain equally obscure.

To get the full flavor of the religious class-rule doctrine in our own days one has to go to Russia. There a distinguished philosopher and defender of Russian autocracy, Leontyeff, will inform us that the basis of the Russian state and society is Greek orthodoxy, Byzantinism. He will tell us that the Byzantine ideal is discouragement in regard to everything earthly, including personal happiness and personal purity. Leontyeff will further tell us that Byzantine Christianity teaches strict subordination. It teaches that the worldly, the 
political hierarchy is but the reflection of the heavenly hierarchy; that there is no equality, because the church teaches that even angels are not equal among themselves. ${ }^{88}$ Christianity accordingly offers the surest and most practical means of ruling the masses of the people with an iron hand. But this power only true Christianity has, not Christianity d l'eau de rose, with its talk about love without fear, the dignity of human nature and the good of mankind. ${ }^{30}$ Love of mankind is anthropolatry and is un-Christian. Fear is the basis of faith. Everybody can comprehend fear, fear of punishment here and hereafter; and who fears is humble, who is humble seeks authority and learns to clove the authority above him. ${ }^{40}$ Authority is constructive, is organizing. Organization, social organization, is by nature nothing else than chronic despotism, which is accepted by some out of love or for the benefit they derive from this despotism, by others out of fear. Progress therefore lies in limiting freedom, not authority."

Leontyeff, however, did a grave injustice to Luther. and his church when he claimed for Greek orthodoxy the monopoly of this theory. With the social prob-

"' Lrontyerr, Vostok, Rossia i Slovianstvo (Moscow, 1885), vol. i, p. 8I; vol. ii, p. 4I. See also Simrнovirce, "An Interpretation of Russian Autocracy," The International Quarterly, October, 1904, pp. 2, 3.

"Ibid., vol. ii, p. 48.

$\because$ Ibid., vol. ii, pp. $268,269$.

"I Ibid., vol. ii, p. 288. 
lems of their days Luther and Melanchthon dealt in very much the same spirit. A prince, Luther preached, remains a prince no matter how tyrannical he may be. Those that he beheads are necessarily few, since he must have subjects in order to be a ruler. A Christian must remember that Christ said: "Resist not evil." The demand for freedom on the part of the peasants outraged Luther's sensitive soul. He found it to be in direct contradiction to the Gospel; for did not Abraham and other prophets have serfs? Besides, it would rob the lords of their serfs, their property! Such a demand, moreover, would make all men equal. Impossible! An earthly kingdom cannot exist without inequality of persons. Some must be free, others serfs; some rulers, others subjects; as St. Paul says: "Before Christ both master and slave are one." Melanchthon entirely shared Luther's views. If serfdom exists, it should be left alone. The Gospel does not require a change in the serf's condition, but it does require obedience to the government. Concerning the treatment of peasants, Melanchthon thoughtfully observed " that the Germans are such a rough, obstinate, bloody-minded people that they should be treated even more harshly than they are"; and a nobleman who sought Melanchthon's opinion about freeing his peasants from certain burdens received this advice: "Your lordship should not abolish the old services, and your conscience need not be troubled on this point. Discipline in bodily matters is well-pleasing to God; and 
if the burdens fall unequally and are too hard, we must remember what St. Paul says: "The powers that be are ordained of God." " 42 It is in this attitude of all the churches that we find the explanation of the curious phenomenon already noted-that all political revolutions in continental Europe were preceded by a general and furious onslaught on church and religion. The church invariably used its authority to sanction and uphold the existing organization of society ; the revolution invariably began by undermining the prestige of the church. So it was in France; so it was in Germany; so it was in Russia.

We have seen that in France the existence of classes and class struggles was a commonplace conception; but the French spokesmen of socialism never justified their theories on the basis of class struggle. Their pet theories were not to be for the benefit of a class but for humanity at large; their appeal was addressed not to the laboring class but to the well-meaning and just of all classes. The fact that various classes of society acted politically in accordance with their respective economic interests led the socialists to inveigh against the selfishness of existing society; but the socialist movement itself did not seem to them a movement actuated by class interest. Such was the situation in France.

In Germany the political radicalism of the forties, for reasons indicated above, expressed itself theoretic-

"SHAPIRo, Social Reform and Reformation (1909), pp. 78-83. 
ally in criticism of religion. Ludwig Feuerbach with his Wesen des Christenthums swept radical Germany off its feet. His book appealed both to the radical democrats and to the socialists. Without a word about politics, it became in a sense a political platform. No modern reader of the book can see why it should have played such a rôle; but the evidence of its effectiveness is conclusive. Engels tells us: "And then came Feuerbach's Wesen des Christenthums . . . one must have himself experienced the emancipating influence of this book to have a conception of it. The enthusiasm was universal, in a moment we all turned Feuerbachians." 43 Does this mean that they became merely atheists and materialists? No; it was Feuerbach's humanitarian idealism, his love of mankind instead of love of God, his " homo homini Deus" and his indirect attack upon state, church and society as constituted in feudal Germany that made converts. Feuerbach himself later acknowledged the political meaning of his work. He wrote in 1846 : "Who has nothing more to say about me than that I am an atheist says and knows of me nothing. The question whether a God exists or does not exist, the opposition between theism and atheism, belongs to the seventeenth and eighteenth centuries, but no longer to the nineteenth. If I am denying God, it means that I am opposing the denial of mankind; it means that instead of a situation full of illusions, instead of a fantastic, heavenly position,

"Engels, Ludwig Feuerbach, pp. 10, 11. 
which in real life is necessarily accompanied by an actual denial of mankind, I demand man's sensuous real place, which also necessarily means his political and social position. The question of God's being or not being is with me a question of men's being or not being." 14

The essence of Christianity has been interpreted as the essence of human nature, which is at present unrealized because of the misdirection of humanity's yearnings. This became the thesis of German socialism, of which Karl Grün and Moses Hess became the leading exponents. Ludwig Feuerbach's doctrine was to them the alpha and omega of all philosophy and of all political science. ${ }^{45}$ The problem of socialism was how to make the people conscious of their own in-.. stincts of love and righteousness. ${ }^{46}$ It was out of the question to divide humanity into classes with different interests; Christianity was the ideal of the people as

“ Ludwig Feurrbach, Werke (Leipzig, 1846), vol. i, pp. xiv, xv.

A6 "When Feuerbach is named the entire work of philosophy from the time of Francis Bacon to the present day has been mentioned. What philosophy purposes and signifies in the last instance has at once been stated, and humanity is thus revealed as the last resort of universal history. In this way one can work more securely because more profoundly than by bringing to the front wages, or competition, or the defects of constitutions and laws." KarL GrüN, "Feuerbach und die Socialisten," Deutsches Bürgerbuch für 1845 (Darmstadt, H. Püttmann, 1844), p. 74

"KArL GrüN, "Politik und Sozialismus," in Rheinische Jahrbücher sur gesellschaftlichen Reform (Darmstadt, 1845), vol. i, p. 98. 
a whole, an instinct of the human species. All that the German socialists had to do was to show to the humane German people, without distinction of classes and parties, that socialism . was the only actual realization of their natural human instincts. The German, moreover, was different from the Frenchman and the Englishman; he was no narrow-minded party man; he had a soul receptive to theories. To make of the humane German a humanitarian, i.e., a socialist, was only a matter of theoretical argumentation. ${ }^{47}$

While the German socialists were working out their philosophical arguments for a humanitarian socialism, they were rudely surprised by a book of the young German scholar, Lorenz von Stein, famous in later years as a teacher of political science. Stein was a gentleman of conservative leanings, a monarchist and a strict defender of private property, yet he came nearer than any other writer to being the actual forerunner of Karl Marx. ${ }^{48}$ In the socialist movement he

"I Ibid., p. 136.

${ }^{4}$ To what extent Stein influenced Marx is an open question. Marx was thoroughly familiar with Stein's work; his articles against Grün, in Das Westphälische Dampfboot, prove it; but on the other hand Marx in 1844 became acquainted with the same sources, the same French history, the same social struggles, which inspired Stein. In fact Marx corrects Stein in many details, and does not seem conscious of being indebted to Stein in any way. So, in speaking of Grün's history of the social movement in France and Belgium, he remarks: "It is hence evident that Grün's bungling composition stands far below Stein's book, for he at least attempted to depict the connection between socialistic literature and the actual development of French society." Das Westphälische Dampfboot, redigirt von 
saw a proletarian class movement; in the socialist theory, an inevitable class theory. In spite of its Hegelian phraseology, Stein's work was a realistic interpretation of half a century of French history and political theory. ${ }^{49}$ It was the first interpretation of this kind attempted by a German, and it displayed much deeper insight and a far keener analysis than was to be found in the interpretation placed upon the same movement by his brilliant French predecessors. So far as the knowledge of the present writer extends, Stein was the first historian of the fourth estate, the philosopher of its coming revolution, and the only one who dealt with this subject without partiality or bias. Stein might have well said with Spinoza: "C $\mathrm{Cl}$ ravi humanas actiones non ridere, non lugere, neque

DR. Otro Lüning, Jahrg. III (Padeborn, Januar, 1847), p. 446. In the same article, on pp. 448,449,45I, Marx criticises and corrects various details in Stein's book; and on p. 456 he makes the interesting remark: "Stein himself betrays extreme confusion when he speaks of a political moment in the science of industry. He shows nevertheless that he had a correct conception of the matter, for he added that political history was intimately connected with political economy." Here is Marx's first definite suggestion of his economic interpretation of history, and he acknowledges that Stein was on the same track. This article was written in 1846 .

"An unsigned article, "Der Socialismus in Deutschland," appeared in the Gegenwart, Heft 81 (Leipzig, 1852), pp. 517-562. I am quite convinced that this lengthy article was written by Lorenz Stein himself; there is an overwhelming amount of internal evidence for such an assumption. In this article Stein pays to himself very high tribute and greatly exaggerates the political importance of his book, but he does not praise himself sufficiently for his real achievement-his realistic method. 
detestari, sed intelligere"; 50 and in the effort to understand them Stein was successful.

In the preface to his book, Stein declares that the period of political revolutions is over, but a revolution not less serious is impending. Just as, at the end of the eighteenth century, an estate of the people rebelled against the state, so now a class is working to overthrow society itself. The next revolution can only be a social revolution. ${ }^{51}$ Moreover, it is not France alone that is confronted by this peril. No deep and farreaching movement belongs exclusively to one nation. Where the general conditions of existence are more or less the same, as they are among the West European nations, the same social movements are bound to manifest themselves with greater or less force.

The first chapter of Stein's book is entitled "Das Proletariat." The proletariat Stein defines as the class of those who have neither property nor education, but who feel that they should not be without these possessions, which alone lend value to personality. The fate of this class is what socialism and communism have in mind. ${ }^{52}$ The first appearance of the proletariat in

"O "It has been my aim not to laugh at the actions of men, nor yet to deplore or detest them, but simply to understand them."

"2 Stern, Der Socialismus und Communismus des heutigen Frankreichs (Leipzig, 1842), p. iii. As regards Stein's theory of society and of the state, see Munroe Smith, in Political Science Quarterly, vol. xvi (1901), pp. 649-656.

"STEIn, Der Socialismus, p. 7. 
French politics was as sudden as it was dramatic. Before the Revolution only three classes could be considered, the nobility, the clergy and the third estate, classes represented in the States-General. The Revolution broke out; the king and his army surrounded with bayonets the Assembly of Versailles; Paris rose, and the people of Paris compelled the king to treat their representatives as a power. Another attempt was made by the king to regain his power; the people of Paris stormed the palace and the king became their prisoner. Who were these people who defended the National Assembly, imprisoned the king, formed Henriot's guard? Who were the "tricoteuses" and the "aimables faubourgs"? These were the proletariat of Paris, which thus made its entry upon the stage of French political life, never again to leave the scene. ${ }^{53}$ During the eventful years of the Revolution and of the first Republic this proletariat learned two things: it became conscious very promptly of its own importance in everything pertaining to revolution; it also learned gradually to regard itself as a separate class, distinct from all other classes. This twofold knowledge later generations of the Paris proletariat have not forgotten. On the contrary, realizing their power and their distinct interests, they have occupied themselves in working out aims of their own. Thus out of the propertyless, uneducated masses is rising one single-minded, unified social class. You may doubt its

"Ibid., p. 8. 
justification, you cannot doubt its power. This is the new element in French society, Stein writes, "which may very properly be called a dangerous element; dangerous on account of its numbers and its often tested courage; dangerous because of its consciousness of unity, dangerous because of its feeling that only through revolution can its aims be reached, its plans accomplished." 54

Further on Stein explains that the "poor" and the "proletarian" are widely differing conceptions; that from time immemorial society has been divided into rich and poor, but that the proletarian belongs to the history of our own times exclusively. In our own days therefore we shall see the development of the significance of this class. That is the point of view from which Stein looked upon France's social movement and its theories. He was not preaching any doctrine, he was calling attention to a fact; but this fact was the opening of the proletarian class struggle. ${ }^{.5}$

Stein's book was very annoying to the German socialists, with their Feuerbachian doctrines and their belief in the humanitarian instincts of mankind. Thus Hess, without naming Stein, refers to him as an intel-

"Stein, Der Socialismus, p. 9. This book was written six years before the Communist Manifesto!

- The importance of Stein as forerunner of Marx was pointed out first by Peter von Struve, to whom we are indebted for much material, in his article "Zur Entwickelungsgeschichte des wissenschaftlichen Sozialismus," Neue Zeit, Jahrg. XV (1897), vol. ii, pp. 228-235, 269-275. 
lectual plebeian, who explains the origin of socialism by the needs of the stomach, because he himself probably never felt other and higher necessities. ${ }^{58}$ In an earlier criticism Hess accuses Stein of being realistic. Of course such simple words as " realistic" were not used in those days by German scholars. A tear on the cheek of his sweetheart would probably have been called, by a learned German of those days, not a tear but a manifestation of the substantialization of the Category of the Tragic. Stein, accordingly, is not described as a "realist," but is accused of being too feeble so to mold reality as to make it fit his own selfconsciousness, for which reason he so molds his consciousness as to fit the low and base realities of existence. ${ }^{37}$ According to Hess, Stein does not understand the socialist movement at all $;^{58}$ all he sees in socialism is its relation to the proletariat. ${ }^{30}$ But after all, reasons Hess, Stein's limitations result from his being an Hegelian and not being an atheist. One so handicapped could not possibly grasp the positive meaning of socialism: he could see only its negative and destructive tendencies. ${ }^{\circ 0}$ Equally harsh is Karl Grün. To him the idea that the proletariat is a separate class

"M. Hess, "Ueber die sozialistische Bewegung in Deutschland," in Neue Anekdota, herausgegeben von Karl Grün (Darmstadt, 1845), p. 226.

"[Hess], "Socialismus und Communismus," in Ein und zwanzig Bogen aus der Schweiz, herausgegeben von Georg Herwegh (Zurich und Winterthur, 1843), p. 75.
- Ibid., p. 83.
" Ibid., p. 85 .
"Ibid., p. 9 I. 
of society and that economic conditions are responsible for socialism seems imbecile (schwachsinnig). No! Socialism is religion, religion that has become practical, etc. ${ }^{61}$

Stein's class-struggle theory obviously made an impression on Germany, because again and again Hess and Grün felt themselves forced to defend the good character of humanity at large and of Germany in particular. In the preface to The Social Conditions of the Civilized World, Hess gives us in nuce his theory on the subject. He tells us that no single class of society nor this nor that form of government is responsible for the evils from which we are suffering. No class of society is so heartless as to leave its fellowmen in misery, were there means at its disposal to make all men happy. We see daily in the well-todo class attempts to better social conditions. The responsibility for all social evils is to be sought in lack of insight. The best proof against any class theory is the fact that, after two years of discussion, Germany's educated and well-to-do people are in the main already in accord with the have-nots in France. ${ }^{.2}$

'1 KarL GrüN, Neue Anekdota (Darmstadt, 1845), pp. 262, 263.

"2 "While we are here disclosing an actual picture of the social conditions of all civilized lands, we are most firmly convinced that neither a single class of our society,-for example, the property-owning class,-nor this nor that form of government, and least of all human nature, is the fundamental cause of the many evils under the burden of which we groan. For no class of society would be so heartless as to leave its 
The German philosophical socialists were without exception insignificant people, and their theories were of little consequence one way or another, but on the eve of the outbreak of 1848 they sounded a shrill note of discord. These quasi-radicals, peddling atheism and preaching a love-feast of mankind, declared themselves indifferent to political reform and to representative government. And it was this circumstance that brought down upon their heads Marx with all his fury and with his Communist Manifesto.

Just as they had copied Feuerbach (whose avowed aim, however, was a political one), so they proceeded to copy certain phrases of the French socialists. In France the people had a constitutional form of governfellow-men in misery if there were a means at its command to make them happy. We see, indeed, every day that especially among the class of property-holders, and without doubt because that is also the cultured class, the attempts fundamentally to better our social conditions make the deepest appeal, and meet with the greatest sympathy; and if until now in our country the classes less favored of fortune have troubled themselves less as to the amelioration of our conditions, it is in truth through no ill-will on their part. Rather it is entirely owing to a lack of insight that they do not concern themselves with a worthy task, and one which is directed, above all else, toward the betterment of their own lot. Is not the very fact that the property-owning class in Germany, although it has been interested in the social question for barely two years, is already in the main in accord with the proletariat of France, and that it is being completely carried away by the movement, - is not this sufficient evidence that neither this nor any other class of society is the cause of the existence and continuance of our many social evils?" Die gesellschaftlichen Zustände der civilisirten Welt, herausgegeben von M. Hess (Elberfeld und Iserlohn, Julius Bädeker, 1846), vol. i, pp. I, 2. 
ment, and for that reason they could afford to sneer at constitutional government or make jokes about it. Nobody could take away from them their political liberties; they could therefore abuse these liberties in their socialist propagandist literature as much as they pleased. In Germany the situation was different. In Germany those who talked and wrote about a constitutional form of government were engaged in a discussion de lege ferenda and not de lege lata; and French socialistic phrases on the subject were, from a campaign point of view, very much out of place. In fact, those who repeated them were playing into the hands of the reaction. Yet we hear Grün asking: Who demands a constitution in Prussia? and answering: The Liberals. But, he continues, the Liberals are not the people. These are a few men of property and some writers. Under a constitution the will of a small minority only will rule-the minority which represents the vested interests. If the Silesian proletariat were conscious it would have petitioned against a constitution. But since that proletariat is not a conscious group, we are acting in its name, we are protesting against a constitution. ${ }^{83}$ Arnold Ruge, one of

"a "A constitution is governed by law, which is the headsman, so to speak, who executes ruthlessly the will of a small minority, assuming an artful appearance of being an infinite majority, and, indeed, of representing the will of the whole country. Were the Silesian proletariat conscious, and did its rights correspond to its consciousness, it would have petitioned against the constitution. The proletariat, however, has neither 
the leading democratic writers of the time, represents Hess as declaring that all the talk about a republic, a jury system and a free press is nonsense; that it only leads to the tyranny of the property-holders over the majority of mankind. ${ }^{64}$ Hess himself tells us that he is disgusted with the liberal-political aspirations, and that he is disposed to trust the heart of a Prussian monarch rather than a French Chamber of Deputies. ${ }^{\text {os }}$ Thus German philosophical socialism had ceased to be harmless nonsense, it had actually become politically reactionary - a circumstance which did not endear its advocates and their theories to Marx and to Engels.

consciousness nor rights. We are therefore acting in its name. We protest." K. Grüs, "Politik und Sozialismus," in Rheinische Jahrbücher zur gesellschaftlichen Reform (Darmstadt, 1845), vol. i, p. 100 .

- "The talk of freedom and political reform is out of date. The republic, the jury system, and the freedom of the press lead to nothing but the tyranny of the property-holder and the slavery of the masses. All political reforms, even the most radical, are impotent against the fundamental evils of society, and no longer interest the world. It is social reform that interests us now." ARnold Ruge, Werke (2d ed., Manheim, 1848), vol. v, p. 39 .

"s "Or has the Prussian monarch shown less heart for the misery of the poorer classes than the French Chamber of Deputies, or the king of France? We are so convinced by facts of the contrary, we are so persuaded by reflection of the true and fundamental causes of our social misery, that all political-liberal endeavor has become not merely indifferent and a mere matter of form to us, but actually distasteful. We are morally disgusted with such political liberalism if in view of the intellectual and physical misery of the working classes . . . it still chases its illusions." HEss, Die gesellschaftlichen $Z u$ stände der cirilisirten Welt, p. 2. 
Marx started as a revolutionary democrat, and he remained first and last a philosopher of revolution. Not a phrasemonger but a profound dialectician, he was forced to abandon abstract Germany. In Paris, treading those hot pavements on which the Revolution of 1848 was hatching, breathing a heavy storm-laden air, he studied the social movement. There he found what his soul was craving: not logical antitheses, but classes struggling, moving and making history. Was it a momentary blaze, a people in fever? Even so, when the people have such a fever it is the king who dies. But no, it was no casual outburst. Nothing is accidental in history. Inevitable is history's majestic course; it moves "nach ewigen, eheren, grossen Gesetzen," the key to which Marx felt in his hand. The power, it seemed to him, was already in the hands of that class to which his heart was so strongly drawn. Then why not proclaim it, why not organize the millions of suffering humanity in the name of class struggle? Why this talk about love and justice? Why obscure the issue just at the moment when a clear insight was needed? Why not tell the bourgeoisie that the proletariat would do to them just what they had done to feudalism, with the same right and the same necessity? Thus Marx entered the scene, carrying to their ultimate conclusion the class-struggle ideas of the French and trampling at the same time upon the various philosophical brands of home-made German socialism. 


\section{CHAPTER IX}

\section{THE MARXIAN CLASS-STRUGGLE DOCTRINE}

All political and historical philosophies have in common one delightful quality: they are all very human; they all echo our hearts' desires; like clouds they may vary in shape and color, yet they always tell us from what corner the wind blows. Simple is the make-up of our political philosophies; a little informal logic and much specially prepared history. And yet were it not for political and religious sectarianism we might not have had any history at all. Facts were gathered for a purpose, and they were interpreted, whether by Tacitus or Orosius, Bossuet or Buckle, to give a substance to a shadow, to prove and visualize "what history teaches us."

Mephisto thus amused himself with social science:

"Was ihr den Geist der Zeiten heisst, Dass ist im Grund der Herren eigener Geist, In dem die Zeiten sich bespiegeln." 1

But the poor devil did not seem to realize that just because our histories and political doctrines truly re-

1 "What you call the spirit of the times is in reality the spirit of the hosts who mirror themselves in the times." 
flect our dreams, aspirations, hesitancies and fears, these reflections are themselves historical monuments of incalculable value. To criticise a political doctrine abstractly and systematically is but our way of overcoming it. Our criticism shows that the doctrine is not somewhere back of us, where we can see it in perspective and see through it, but right in front of us, barring our path; and our logical argument is a passionate effort. All these passionate arguments, all the claims, ever so naive, of those that have come and gone before us have become precious material for a deeper and truer understanding of social life.

Marx is so close to us, his arguments are so current, that we are compelled to take up each doctrine of his by itself, analyze it and show where it is wanting. There is, however, a quality in Marxism of which we must not lose sight. Marxism as a whole is a class doctrine, a proletarian doctrine. Just as our classical political economy damned labor with its Malthusianism and its wage-fund theory, cursed the landed interests with its rent theory and fought like a wildcat with every ounce of its eternal principles against any and every regulation on the part of the state that might decrease the profits of the industrial bourgeoisie,-just so is Marxism a class doctrine of the industrial proletariat. $^{2}$ Each of its theories

2 "Marx's historical merit consists in the fact that he gave to the proletariat a class doctrine that corresponded to the imperative needs of the class struggle of the time, and this is 
breathes class feeling, whether it be the theory of surplus value, that of concentration of capital or that of increasing misery. Marx's scientific forecasts are but class yearnings. ${ }^{3}$ His doctrine of class struggle has the same quality: it is a doctrine exaggerated and intensified by his class bias, by his hatred of the past, by his hope of the future. Here his passions come to a focus; here his raptures are too exultant to bother about conventionalities of objectivity, to care about outward consistency. Here he failed, but failed magnificently. The failures of the great often surpass the achievements of mediocrity. Marx's doctrine, with all its bias and all its faults, marks a signal advancement of our science.

There is an attempt on foot to make out of the Marxian class-struggle doctrine an extension of the

the cause alike of the tremendous outward success and the inner weakness of his system." FrANZ OPPENHEIMER, Das Grundgesetz der Marx'schen Gesellschaftslehre (Berlin, 1903), p. I46.

- "From the standpoint of the class struggle the great theoretical problem was:-the origin of surplus value, that is, the scientific explanation of exploitation, and the tendency toward socialization of methods of production, or the scientific explanation of the objective foundations of the social revolution. Both questions were answered in the first volume [of the Capital], which inferred 'the expropriation of the expropriator' as the inevitable outcome of the production of surplus value and the advancing concentration of capital. The theoretical needs of the labor movement were on the whole satisfied by this." Rosa Luxemburg, "Stillstand und Fortschritt im Marxismus," in Vorwärts, March 14, 1903. The unconscious admission in the last phrase of this Marxist writer is psychologically very interesting. 
Darwinian principle of struggle for life. Such an interpretation is but a mouthful of big words that sound impressive but mean nothing. The Marxian version of the doctrine antedates Darwin's work by twelve years. The class-struggle conception itself, as we have seen, was set forth even earlier by Guizot and his predecessors; the conception of historical necessity and continuity was formulated by Hegel. .To bring Marx's economic interpretation of history into the theory of universal evolution is at its best, as Labriola puts it, "a new metaphor of a new metaphysics." " And yet even Kautsky helped to confuse the issue by making of Marx's class struggle a form of the universal natural law of development. ${ }^{5}$ Lester F. Ward has thus an excuse for making the erroneous statement that "the socialists, for the most part, regard the social struggle as a practical extension of the biological struggle into the human field." " Fortunately, we are in possession of a letter from Marx, dated I87o, in which he characterizes the first attempt to interpret social struggles in the light of the "struggle for life " as cheap humbug. ${ }^{7}$

- Labriola, Essays on the Materialistic Conception of History (Chicago, 1908), p. 19.

" "For Marx, on the other hand, the class struggle was but a particular instance of the universal law of evolution, whose essential qualities are in no case peaceful." Kautsky, Die historische Leistung von Karl Marx (Berlin, 1908), p. 15.

"Lester F. Ward, "Social and Biological Struggles," American Journal of Sociology, vol. xiii (1907), p. 289.

"Karl Marx, "Briefe an Dr. L. Kugelman," Neue Zeit, Jahrg. 
Let us see how Marx and Engels themselves looked upon their class-struggle theory. They invariably acknowledged Hegel as their teacher. It was Hegel who first looked upon history as a necessary, uninterrupted process of the evolution of mankind. ${ }^{8}$ This conception Marx and Engels adopted; but they could not follow Hegel in his idealism; they did not accept his theory that the evolution consisted in the realization of the preëxisting "Idea." Another very sound objection which they raised against Hegel's doctrine was that " upon the one hand its essential proposition was the conception that human history is a process of evolution, which, by its very nature, cannot find its intellectual final term in the discovery of any so-called absolute truth. But on the other hand, it laid claim to being the very essence of this absolute truth. A system of natural and historical knowledge, embracing everything and final for all times, is a contradiction to the fundamental law of dialectic reasoning." " Fur-

$\mathrm{XX}$, vol. ii (1902), pp. 54I, 542. The following is an extract from a letter dated June 27, 1870: "Mr. Lange (The Labor Question, 2d ed.) praises me greatly, but merely to call attention to his own importance. One great natural law underlies the whole of history. This natural law is the phrase-the Darwinian expression employed in this way is but a phrase'struggle for life,' and the import of this phrase is the Malthusian doctrine of population, or rather his law of overpopulation. It must be admitted that this is mental indolence and a most impressive fashion of spreading bombastic ignorance masquerading as science."

- Engres, Socialism, Utopian and Scientific (New York, 1901), p. 24

- Ibid., p. 25. 
thermore, Hegel's conception of history knows nothing of the relations of economic interests or of class struggles based upon these interests. We already know that Marx and Engels did not have to go far to hear about or see these struggles. They were there, on the spot, when Proudhon was cheerfully explaining to the French bourgeoisie: "Ce n'est pas Catilina, qui est à vos portes, c'est la mort" ("It is not Catiline who is at your gates; it is death"). But to proceed with Engels's history of the doctrine: "The new facts made imperative a new examination of all past history. Then it was seen that all past history, with the exception of its primitive stages, was the history of class struggles; that these warring classes of society are always the products of the modes of production and of exchange-in a word of the economic conditions of their time; that the economic structure of society always furnishes the real basis, starting from which we can alone work out the ultimate explanation of the whole superstructure of juridical and political institutions as well as of the religious, philosophical and other ideas of a given historical period. From that time socialism was no longer an accidental discovery of this or that ingenious brain, but the necessary outcome of the struggle between two historically developed classes-the proletariat and the bourgeoisie. Its task was no longer to manufacture a system of society as perfect as possible, but to examine the historico-economic succession of events from which these 
classes and their antagonism had of necessity sprung, and to discover in the economic conditions thus created the means of ending the conflict." 10

The development of the forces of production thus took the place of Hegel's absolute "Idea"; these forces moved history, and they moved it through class struggle. Every system of production necessitated certain relations of production, a certain division of labor and certain legal institutions. In the last analysis, accordingly, our own social order is dependent on our own method of production. "As in religion man is governed by the products of his own brain, so in capitalist production he is governed by the products of his own hand "; and this, according to Marx, is equally true of all preceding eras. ${ }^{11}$ Social production has always brought about of necessity a division of labor, and the division of labor has divided society into classes. Despite all the multiplicity and variety to be found in the social relations of the past ages, they have one common trait-the exploitation of one part of society by another. ${ }^{12}$ It does not require deep intuition to comprehend that a man's ideas and views are influenced by the conditions of his material existence. ${ }^{13}$ Where the existence of one group depends upon the exploitation of another group, the general ideas of these two groups are bound to be antagonistic.

${ }^{20}$ Ibid., pp. 26-27.

${ }^{11}$ MarX, Capital (4th ed., London, 1891), pp. 634, 635.

${ }^{12}$ Communist Manifesto, p. 44.

${ }^{13}$ Ibid., p. 42. 
The oppressor and the oppressed must stand in opposition to each other; and "the history of all hitherto existing society is the history of class struggles." 14 In all past ages we find a complicated division of society into ranks and classes. In Rome patricians, knights, plebeians, slaves; in the Middle Ages feudal lords, vassals, guild-masters, journeymen, apprentices, serfs. Modern society did not abolish class antagonisms; it only substituted new classes, new antagonisms, new forms of struggle in the place of the old ones. But, Marx continues-and this, as we shall see, is a crucial statement- "Our epoch, the epoch of the bourgeoisie, possesses, however, this distinctive feature; it has simplified the class antagonisms. Society as a whole is more and more splitting up into great hostile camps, into two great classes directly facing each other: Bourgeoisie and Proletariat." ${ }^{15}$ With the development of industry the proletariat is concentrated in great masses; its strength increases, and it becomes more and more conscious of its strength. The industrial proletariat forms local combinations, trade unions; to keep up the rate of wages, they go through the school of struggle. Modern means of communication soon bring all the local organizations into close touch; and thus the industrial proletariat becomes organized into a class, which is disciplined and ready for battle. "The proletarian movement is the self-con-

14 The opening words of the Communist Manifesto.

1s The Communist Manifesto, p. 13. 
scious, independent movement of the immense majority, in the interests of the immense majority. The proletariat, the lowest stratum of our present society, cannot stir, cannot raise itself up, without the whole superincumbent strata of official society being sprung into the air." 16 The proletariat is therefore the only really revolutionary class. Other classes are destined to decay, while the proletariat is marching towards victory. What is the proletariat clamoring for? The conquest of political power. Addressing himself directly to the dominant class, Marx says: "Your jurisprudence is but the will of your class made into a law for all, a will whose essential character and direction are determined by the economical conditions of existence of your class ${ }^{17}$. . . The executive of the modern state is but a committee for managing the common affairs of the whole bourgeoisie." 18 In order to accomplish its task the proletariat must first of all wrest political power from the hands of all other classes. Only through a dictatorship of the proletarian class can the social revolution attain its object-socialized production and, with it, the abolition of all classes. The true socialist movement is a declaration of war, of civil war, of revolution-Permanenzerklärung der Revolution! ${ }^{10}$

\section{${ }^{10}$ Ibid., p. 30.}

${ }^{17}$ Ibid., p. 39.

${ }^{18}$ Ibid., p. 15.

10 "While the Utopia, the doctrinaire socialism, subordinates the entire movement to one of its elements, and sets up in the place of communistic, socialistic production the mental activity of a single pedant, while it above all does away with the revolution- 
Thus, we see, Guizot was quite right in saying that no class has ever made its appearance in human history with more audacious demands-no sharing of power, no compromise, but dictatorship by the proletariat and the complete upheaval and uprooting of all existing economic and social relationships. This end cannot be achieved by Sunday-school picnics of parlor socialists, but only by a social revolution. "Let the ruling classes tremble at a communistic revolution. The proletarians have nothing to lose but their chains. They have a world to win." ${ }^{20}$ And if promises are to be made good, no quarter is to be given in the winning of this new world. In the last number of Die neue Rheinische Zeitung Marx tells us: "We are ruthless and want no consideration from you [the bourgeoisie]. When our turn comes, revolutionary terrorism will not be sugar-coated. . . . There is but one way of sim-

ary class struggle, together with all that this involves, by little measures and large sentimentalities, - while this doctrinaire socialism which at bottom merely idealizes present society, picturing it without shadows and opposing its own ideal to reality ... the proletariat is gathering more and more to the standard of revolutionary socialism and communism, which the bourgeoisie has had interpreted to it by Blanqui. This socialism is the declaration of a permanent revolution, of the dictatorship of the proletariat, and is a necessary agency and starting point for the abolition of class differences, and of all conditions of production upon which they rest, of all social relations which correspond to these conditions of production, resulting in the overthrow of all ideas which arise from these social conditions." KaRL MaRX, Die Klassenkämpfe in Frankreich: 1848-1850 (Berlin, 1895), pp. 94, 95 .

${ }^{20}$ The closing lines of the Communist Manifesto. 
plifying, shortening, concentrating the death agony of the old society as well as the bloody labor of the new world's birth-revolutionary Terror." ${ }^{21}$ Accordingly the Communist Manifesto promises that, as soon as the proletariat becomes the ruling class, the reorganization of society will begin " with despotic inroads on the rights of property and on the conditions of bourgeois production." The proletariat, however, is not to remain permanently in dictatorship as a class, since with the reorganization of society on the basis of socialized production all classes will disappear. "Political power, properly so-called, is merely the organized power of one class for oppressing another. If the proletariat during its contest with the bourgeoisie is compelled by the force of circumstances to organize itself as a class, if by means of a revolution it makes itself the ruling class and, as such, sweeps away by force the old conditions of production, then along with these conditions it will have swept away the conditions for the existence of class antagonisms and of classes generally, and will thereby have abolished its own supremacy as a class." 22 But the proletariat is not to abdicate its dictatorship too soon. Let vengeance triumph; like a blue flame, let it go through the hearts of the people; as a red flame, let it blaze in the cities and the towns. The leaders of the proletariat must see to it "that the revolutionary excitement shall not

${ }^{21}$ Marx, in his newspaper, Die neue Rheinische Zeitung, No. 301, May 19, 1849 .

22 Communist Manifesto, pp. 46, 47. 
subside immediately after the victory is won. On the contrary, this excitement must be kept up as long as possible. Far from stopping so-called excesses, examples of popular vengeance upon hated individuals and public buildings, with which bitter memories are associated, one must not only tolerate these examples but lead and conduct them." ${ }^{23}$

These are fruits from the tree of life, not from the tree of knowledge. The angel of vengeance penned these exhortations; yet they are illuminating so far as Marx the man is concerned. "Ich bin das Schwert und ich bin die Flamme" ("I am the sword and I am the flame") was a striking note in his life. But his thought was deeper and more powerful. His thought was constantly hunting down the cheap pet notions of his revolutionary predecessors and contemporaries, but he could not always free himself from their ideas. Hence his inconsistencies were many, and some of them his followers have frankly acknowledged. In speaking of religions, Feuerbach observes that each religion is extremely rational and sensible in its criticism of other religions; but what it criticises in another religion it will never question in its own doctrine. ${ }^{24}$ This was equally true of Marxism.

But let us consider the class-struggle doctrine; and

${ }^{23}$ Ansprache der Centralbehörde an den Bund, vom März, 1850: Anhang IX der Enthüllungen über den Kommunistenprocess zu Köln (Hottingen-Zurich, 1885), p. 79.

24 "All religions are rationalistic in their attitude toward each other, but as far as they themselves are concerned they are 
let us ask, first of all, what is a "class"? Marx was about to answer the question, when death interrupted his work in the middle of a sentence; and the faithful Engels, who edited the third volume of the Capital, informs us: "Hier bricht das Manuscript ab" (" Here the manuscript breaks off "). But the answer is not difficult: groups having similar sources of revenue and conscious of similar or identical economic interests may be called social classes. Of course a class does not exist in flesh and blood, any more than the "ordo felis" of the zoölogical textbooks. It is a matter of grouping; and we accept an economic classification of society as scientifically useful. The significance of social classes, however, may easily be misinterpreted. Marx dealt with such classes as political economy had long dealt with the economic man. The economic man is entirely actuated by his personal economic interests. It is doubtful whether Wall Street could exhibit a perfect specimen of an economic man. The social class is an ideal body of economic men whose economic interests coincide: it represents a community of interests.

The social classes are in constant struggle. Do interests always involve struggle? Are battle, murder and sudden death in the self-interest of those that die? A bullet in the breast is not in the interest of the one that gets it, but a soldier dies that his country may

blind. For themselves they make an exception from a universal rule, but in others they dispute what in themselves they never question." L. FeuErbach, Werke (Leipzig, 1846), vol. i, p. 66. 
live. Acute and active struggle is never in the interest of those that struggle, but it may be in the interest of the nation, the group, the class. Those that participate in such a struggle do so out of ideal devotion and loyalty to the group, not out of self-interest. This circumstance makes class psychology much more complex than it appears to be in the Marxian scheme. The economic interests of the individual are simpler than his loyalties and devotions; and if class psychology is based wholly or mainly on economic interests, without due allowance for group loyalties, it becomes simple, indeed, but it is inadequate. One's interests and one's grievances will undoubtedly influence one's ideals; but to what extent it will influence them, and how much of other traditional and broader loyalties and inhibitions it will exclude-these are the real questions.

Marx admits that even our revolutions require traditions, historic memories, deeply rooted loyalties, that overcome our personal fears and lead us to self-sacrifice and heroic action. Yet what he grants for the immediate past, he denies to the immediate future; he expects our social psychology to act to-morrow as if a different mechanism were installed within us. $\mathrm{He}$ tells us: "The social revolution of the nineteenth century cannot draw its poetry from the past, it can draw that only from the future. It cannot start upon its work before it has stricken off all superstition concerning the past. Former revolutions required historic reminiscences in order to intoxicate themselves with 
their issues. The revolution of the nineteenth century must let the dead bury their dead in order to reach its issue. With the former, the phrase surpassed the substance; with this one, the substance surpasses the phrase." ${ }^{25}$

It is well to bear in mind that a definition of a class does not describe the actual make-up of the class or indicate the character of the individuals that belong to it. Every definition is, as Spinoza used to say, a negation. In defining a class we emphasize characteristics which that particular class possesses and other classes do not possess; we emphasize the exclusive characteristics; and in defining an economic class we include from the start as a criterion of the class an economic antagonism to other classes. Working with this criterion, we cannot talk about solidarity of classes with one another, because absence of such solidarity, uncompromising antagonism to other classes, is what in part constitutes a class. This is perfectly sound logic; but only a man of unsound mind will fail to see through it. Even Marx never taught that the struggle of class definitions makes history. In real life, regarded in all its aspects, a class is something quite different from the definition. There is a cohesion, a solidarity in the society to which the individual members of all the classes belong. There is national solidarity, there is human solidarity, there

${ }^{28}$ Kart Marx, The Eighteenth Brumaire of Louis Bonaparte, translated by Daniel De Leon (New York, I898), p. 7. 
are a thousand and one cross-sectional solidarities and loyalties, all of which are ignored in our class definition. Even Kautsky has to admit that the whole is bigger than any one of its constituent parts and that the common interests outweigh the class interests. ${ }^{26}$

If we had class loyalties only, and if these were entirely dominated by the economic interests of the individuals who compose the classes, then Marx's fundamental proposition, that the history of all hitherto existing society is a history of class struggles, would be true. But this proposition is far from true. In his preface to the second edition of Capital, in speaking of earlier English history, Marx states: "Its political economy belongs to the period in which the class struggle was as yet undeveloped." ${ }^{27}$ Thus on the one hand we are told that all history, English history certainly not excluded, is a history of class struggles, and on the other hand we are informed that in the beginning of the nineteenth century class struggle was as yet not developed in England. This is not an unintentional slip, of which an unfair advantage is here taken. The orthodox interpreter of Marx, Karl Kautsky, modifies Marx's statement regarding

28 " The whole is greater than its parts. In the same way the common interest, the social interest, outweighs class interest. ... You forget that it is possible to deny the solidarity of classes, and still recognize the solidarity of mankind." Kautsky, "Klasseninteresse, Sonderinteresse, Gemeininteresse," Neue Zeit, Jahrg. XXI, vol. ii (1903), pp. 266, 274.

${ }^{27}$ Marx, Capital (English 4th ed., London, 1891), p. xxii. 
the importance of the class struggle by saying that only under certain social conditions does class struggle become the motive of history ${ }^{28}$ - a statement quite different from Marx's and of no conceivable use in Marx's system. Marx assumes and is searching for a steady continuity of the historical process. What really constitutes the continuity of the so-called historical process is the misinterpretation of the past in the light of our anticipations of the future; and the assumption that all history turns upon class struggle is the particular misinterpretation which Marx's anticipations require. If class struggles flare up at times only and do not grow in power and magnitude, what assurance has Marx of the inevitable victory of the proletariat and of the subsequent abolition of all classes? To-day a furious class struggle may rage, as it often did in the past; to-morrow social calm may prevail. The mere vision and prophecy that ultimately there will be no classes, that absolute equality will reign, that here on earth we shall have the kingdom of heaven, will neither elicit antagonism nor attract energetic political support. Only results within our sphere of vision, which as a rule is narrow, will incite us to effort; and the nearer our goal, the greater our energy. That is why, in making social theories,

28 "Only under certain social conditions is class struggle the motive of history; it is always in the last analysis the struggle with nature." KAUTSKY, Die historische Leistung von Karl Marx (Berlin, 1908), p. II. 
we always begin with the end, and adopt or manufacture a theory that promises the most immediate accomplishment of the end. Can you show me a popular socialistic theory that expects the realization of its purpose in future centuries? I do not know of any. Before the industrial development made any substantial progress, Babeuf and Blanqui urged conspiracy and forcible overthrow; Fourier and Considérant, Cabet, Owen, Thompson, Weitling and others urged the immediate organization of voluntary communities.

Philosophically advanced, but industrially backward, the Germany of the forties believed in the power of the educated few to mold and reconstruct society, because this was the only possible immediate relief that faith could offer. Radical Russia greeted Marx's works with prompt enthusiasm; but in the sixties, seventies and eighties Russia was a purely agricultural country, without any industry, and therefore without any industrial proletariat. Did the Russian socialists propose to wait for the development of a capitalistic industry? Not at all. They immediately abolished Marx's economic interpretation of history. They argued that the capitalistic stage was entirely unnecessary in Russia, and that Russia could develop its socialized production, etc., from its village community, its mir. ${ }^{20}$ All that was required was the leadership and foresight

${ }^{20}$ See Siмкноvітсн, Feldgemeinschaft in Russland (Jena, 1898), Vorwort. 
of the heroic personality; the masses were but passive material. These doctrines of the so-called "Narodniki" so were so firmly grounded in Russia that Marx's economic interpretation of history, with his class-struggle doctrine, his theory of concentration, etc., could make no headway whatsoever till Russia's industry began to develop with giant strides. Then the theories of the "Narodniki" melted like snow and orthodox Marxism swept the country. Belief in the heroic personality gave way to faith in the proletariat; but the collapse of capitalistic society and the coming of the new social régime with all its glory were expected, as before, in the immediate future. Such is human nature.

What assurance of the future is contained in a theory that at times social classes are in acute struggle, but that these struggles are ordinarily followed by some sort of peaceful modus vivendi? Does such a theory bring us any nearer to the promised land? Clearly not. Hence Marx's desperate assertion that all history is but a history of class struggles.

It is impossible to deny the significance and the influence of class struggles; but to reduce history to nothing but class struggles is an impossible construction. ${ }^{31}$

${ }^{30}$ Srмкнолттен, "Die sozial-ökonomischen Lehren der russischen Narodniki," Conrad's Jahrbücher, 1897, Bd. xiv, pp. $64 \mathrm{r}-678$.

${ }^{31}$ The writer is quite in sympathy with the statement of Tugan-Baranowsky: "The class struggle certainly cannot be eliminated from history; it may even be assumed that of late 
What shall we do with the Napoleonic wars, with the unification of Germany, with the Tartar conquest of Russia? Can we interpret them in the light of class struggle, as Bebel attempted to interpret the abolition movement in America and the American Civil War ? 32 The discovery of printing and its influence upon the cultural development of Europe may also claim a place in history; but it would take greater inventive genius than Gutenberg possessed to hitch his invention to the class-struggle doctrine.

From the fact that all past history bears witness of a subjection of one class to another, of an exploitation of one class by another, Marx jumped to the conclusion that all history is a history of class struggles. Class exploitation and class struggle are, however,

the value of this social element has increased considerably. In spite of this, to-day as in the past, the history of mankind and the history of class struggles by no means coincide, and the assertion of Marx and Engels to the contrary may be characterized as a great error." Tugan-Baranowsky, Theoretische Grundlagen des Marxismus (Leipzig, 1905), p. I29.

32 ". . . Then the great movement for the abolition of slavery in America. There, according to Bernstein's point of view, there were ethical standpoints which were the determining factors in the case. (Laughter.) There was, to be sure, sympathy for the poor slaves. (Laughter.) We see that for the North American bourgeoisie it was well to do away with slave labor, and to clear the way for modern capitalistic development. (Quite right!) Thousands of slaveholders were deprived of their property in slaves. From the ethical point of view that is called plain theft. (Prolonged laughter.)" Protokoll über die Verhandlungen des Parteitages der sozialdemokratischen Partei Deutschlands, abgehalten zu Hannover, 1899, p. I21. 
widely differing conceptions. For instance, we read in the Laws of Manu: "The Brahman is lord of the castes. . . Desertion of life for the sake of a Brahman . . causes the ultimate bliss of outcasts. [A Çudra] should serve the Brahmans for the sake of heaven, or for the sake of both heaven and livelihood. . . . Merely to serve the Brahmans is declared to be the most excellent occupation of a Çudra; for if he does anything other than this it profits him nothing. . . His means of life should be arranged by the Brahmans . . . in accordance with what is fitting. . . . The leavings of food should be given him and the old clothes; so too the blighted part of the grain; so too the old furniture. . . . An accumulation of wealth should not be made by a Çudra even if he is able, for a Çudra getting possession of wealth merely injures the Brahmans." ${ }^{33}$ In this, as in other parts of Manu, we have class legislation, framed for purposes of class exploitation; but we are not aware that the history of the Hindustani was a history of class struggle.

All our economic relations are formulated in law. "The rules of the law," as Brooks Adams observes, "are established by the self-interest of the dominant class, so far as it can impose its will upon those who

"The Ordinances of Manu, translated by A. C. Burnell, completed and edited by E. W. Hopkins (London, Trübner, 1884), Lecture X, Secs. 3, 62, 122-125, 129. 
are weaker." 34 But the weaker were never weak numerically; they were weak because, for varying historical reasons, they did not assert themselves and did not struggle. Abject inertia, class submission, endurance without resistance, are phenomena quite as impressive as class struggle. It is this circumstance that led Loria to the very exaggerated ${ }^{35}$ statement: " It is not beliefs and ideas in general that constitute a factor in history, but only the special beliefs and ideas of the proprietary class. Beliefs and ideas were present in the hearts and minds of the slaves, the serfs and the wage-earners, but these beliefs and ideas have had not the least effect upon the march of history, for they have always been repressed by the beliefs and ideas of the patricians, the feudal lords and the capitalists." 36

The only explanation we can give for the amazing class submission of the past is the fact that the ruling class was organized. Its organization was the state; it therefore could prevent and discourage any organization of the exploited classes; it could also control and hold in check the dissemination of ideas subversive of its interests. Last but not least, the ex-

"Melville M. Bigerow, Centralization of the Law, Lecture I; Brooks Adams, Nature of Law, p. 45.

${ }^{35}$ Loria overlooks the fact that the ideas of the ruling class take account of the ideas of the lower classes and reckon on their possible resistance.

"Achille LoRIA, The Economic Foundations of Society, translated by Lindley Keasbey (London, 1899), p. 371. 
ploited class was as a rule scattered all over the country in small groups, which circumstance alone offered a practically insurmountable difficulty to organization, i.e., to power.

The passive character of the German peasantry Marx himself was obliged to acknowledge: "The small freeholders, the feudal tenants and the agricultural laborers never troubled their heads much about politics before the Revolution. . . . It is quite as evident and equally borne out by the history of all modern countries that the agricultural population, in consequence of its dispersion over a great space and of the difficulty of bringing about an agreement among any considerable portion of it, never can attempt a successful independent movement." 37

So much in regard to class struggles in the past; let us now turn to Marx's views of class struggle in his own days. In his view, the struggle becomes simplified: it narrows down to a struggle between two classes, capitalists and proletarians. The city rules the country; the middle class is being wiped out, pushed down into the ranks of the proletariat; and as the legions of the proletariat are swelling, concentration of capital is rapidly diminishing the number of capitalists. Thus the last ruling class is tottering to its grave. These are startling assertions, very important if true; and the first question that naturally sug-

"Kard Marx, Revolution and Counter-Revolution, or Germany in 1848 (London, 1904), pp. 10, II. 
gests itself is: on what concrete political experiences are these generalizations based?

Marx was a careful student of the French social movement of the time, and we have two valuable monographs of his on the French revolutionary movement. Both of them are determined efforts to interpret the movement in the light of his doctrine. These two monographs were written in 1850 and $185 \mathrm{I}$. The failure of the Revolution he regarded as only a temporary check; the breakdown of the capitalist system and the victory of the proletariat he expected in the immediate future.

French society, however, did not present itself to him as divided into two classes only; rather do we find him dealing with a whole series of classes. At the outset he informs us that it was not the French bourgeoisie that ruled under Louis Philippe, but only a fraction of it: the financial magnates and the stockexchange manipulators. The industrial bourgeoisie (the manufacturers) were in opposition, the peasant class and the petty bourgeoisie (small traders, etc.) were excluded from any participation in the affairs of state. We are also told that the large landed proprietors, who ruled under the July monarchy, were legitimist, and therefore opposed to the Orleanist government. $^{38}$ In fact Marx enumerates even more

${ }^{38}$ MARx, The Eighteenth Brumaire of Lonis Bonaparte (New York, 1898), p. I8; Die Klassenkämpfe in Frankreich (Berlin, I895), p. 20. 
classes that were opposed to the June insurrection of the Paris proletariat. "The bourgeois republic won. On its side stood the aristocracy of finance, the industrial bourgeoisie; the middle class, the small traders class; the army; the slums, organized as Garde Mobile; the intellectual celebrities; the parson class, and the rural population." s9 Have any of these classes disappeared? Have they been pushed down into the ranks of the proletariat? In a preceding chapter I have shown that middle-class incomes are on the increase in every civilized country; that the peasant class and the farmer class are increasing in strength and prosperity; and that the conception of a steadily diminishing number of capitalists (one capitalist killing many) is a chimera. ${ }^{40}$ Where then is the basis for the statement that class struggle is reduced to a contest between capitalists and proletarians? And does even the industrial city population form a single political class? Marx himself distinguishes the so-called social slum (Lumpenproletariat) as not only not revolutionary, but as ever ready material for a reactionary movement, the bribed tool of the counter-revolution. But how is one to distinguish the reactionary slum proletarian from the genuine proletarian? Marx describes the slum proletarians as gens sans feu et sans aveu, lazzaroni, criminals, procurers, the offal and wreck of all classes. ${ }^{41}$ But is it not remarkable that

"MaRx, Eighteenth Brumaire, p. 10. "See Chaps. IV and V. " "They belong in great part to the slum proletariat which in 
Marx could distinguish this section of the proletariat at a glance while, according to his own statement, the working people of Paris could not? Thus they cheered the Garde Mobile (whom Marx describes as the organized slums), recognizing in them their fellows and friends who fought in February on the barricades. ${ }^{42}$ But whether Marx is right or wrong in his characterization of the non-revolutionary proletariat, this much is clear: a very large portion of the so-called proletarian population cannot be relied upon to fight the proletarian battles! Immediate personal interests on the one hand, traditional ideals and national spirit on the other, are powerful factors against class spirit, especially when the latter demands personal sacrifices.

Perusing Marx's own story of the French struggles of 1848 and of the rise of Louis Bonaparte to power, we come to the self-evident and platitudinous conclusion that, if one class presses its own interests to the point of jeopardizing the interests of all other classes, the latter will temporarily lay aside their dif-

all large cities forms a class entirely distinct from the industrial proletariat, and which is a recruiting ground for thieves and criminals of all kinds. Its members, living on the refuse of society, are without any definite occupation, idlers, 'gens sans feu et sans aveu,' diversified as the structure of the nation to which they belong, and always 'lazzaroni." " MARX, Die Klassenkämpfe in Frankreich, pp. 33, 34.

42. "To oppose the Paris proletariat, an army of 24,000 young, strong, foolhardy men were chosen from their own midst. This garde mobile was cheered by the proletarian masses. They recognized in them their heroes of the barricades." Ibid., p. 34 . 
ferences and the aggressive class will come to grief. Louis Philippe and the financial aristocracy managed to exasperate not only the working class, but also the manufacturing interests, the merchants, the tradespeople, the landed proprietors, until all these classes united and contributed to the success of the February revolution. ${ }^{43}$ The triumph of Louis Bonaparte is attributed by Marx to the peasantry. "It was a reaction of the farmers' class, who had been expected to pay the costs of the February revolution." "44 "The French government does not float in the air. Bonaparte represents an economic class, and that the most numerous in the commonwealth of France-the allotment farmer." 45 And this most numerous class is regarded by Marx as the true representative of barbarism within the border-lines of civilization. ${ }^{48}$ It was

13 "The provisional government which rose from the February barricades necessarily reflected in its composition the different parties which divided the victory. It could be nothing but a compromise of the different classes who had together overturned the throne in July, but whose interests were nevertheless antagonistic. The great majority of its members consisted of representatives of the bourgeoisie. The Republican small bourgeoisie was represented by Ledru Rollin and Flocon, the Republican bourgeoisie by writers for the National, the dynastic opposition by Cremieux, Dupont de l'Eure, etc. The laboring class had only two representatives, Louis Blanc and Albert." Ibid., pp. 24, 25.

"MARX, The Eighteenth Brumaire, p. 17.

${ }^{4}$ Ibid., p. 70.

16 "The roth of December, 1848 , was the day of the peasant insurrection, and from that day dated the February revolution of the French peasantry. What marked their entrance into 
not, however, the peasantry alone that tendered Louis Bonaparte the crown. According to Marx he was for various reasons the favorite of all parties: Louis was the "chief of the slum proletariat." ${ }^{47}$ The aristocracy of finance hailed every victory of Louis over the parliament as a "victory of order," and he was recognized as the guardian of order on every stock exchange in Europe. ${ }^{48}$ The mass of the bourgeoisie craved the protection of a strong and unhampered government to the end that "it might ply its own private pursuits in safety." 49 Manufacturing interests forgot their opposition to the exchange manipulators: "What is a diminution of profits by financial manipulators to an abolition of profit by the proletariat?" ${ }^{50}$ Finally, the whole bourgeoisie, " in this unspeakable and noisy confusion of fusion, revision, prorogation, constitution, conspiracy, coalition, emigration, usurpation and revolution, blurts out at his parliamentary republic: 'Rather an end with fright, than fright without end." " 51 Thus ended the second republic, showing

the revolutionary activity was an expression of clumsy cunning, of rascally naïveté, of doltish, sublime and calculated superstition; it was a pathetic burlesque, an anachronism at once the work of genius and stupidity, a harlequinade of greatest historical importance, a hieroglyph undecipherable to a civilized mind;-it marked unmistakably and characterized the one class which represented barbarism in the midst of civilization." MARX, Die Klassenkämpfe in Frankreich, pp. 50, 51.

${ }^{4}$ MARx, Eighteenth Brumaire, p. 4I.

" Ibid., p. 58.

"Ibid., p. 60.

"Marx, Die Klassenkämpfe in Frankreich, p. 84.

"1 MARx, Eighteenth Brumaire, p. 62. 
a remarkable solidarity of classes in the face of a threat, real or imaginary, of economic disorganization.

But the revolution of 1848 and Bonaparte's coup d'état belong to the past. How about the present? The industrial proletariat has undoubtedly grown; but so has the political insight of the other classes. As we have already seen, the middle class and the farmers have not been swept away; the capitalist magnates, instead of diminishing, have grown in number, and they have grown relatively much faster than the proletariat. Marx expected increasing bitterness of class struggle because of increasing misery. In a previous portion of this study it has been conclusively shown that the situation of the working class has improved greatly in the last sixty years. So this prophecy of Marx has also failed of fulfilment.

Representative government based on manhood suffrage has changed the character of so-called class struggles. It has increased their magnitude but diminished their intensity. It has taken from them the bitter quality and the revolutionary character which were so striking in the class struggles of the past. It is reasonable that it should be so. Every law regulating civil affairs affects various interests. When legislation was in the hands of privileged classes, and others were excluded from power, even self-expression was restricted or prohibited. When, for example, the political struggle of interests was limited to the landed 
and moneyed classes, the interests of the farmer and of the laboring city population found no expression; the ruling classes walked over them. But they walked over a volcano. The moment the disfranchised classes were able to organize, their power became dangerous to the very existence of the state, because in the state they saw their enemy, in its laws, the enemy's weapons. The only thing that could save the state was the irrational character of the revolt. Take Russia as an example. There was no peasant class struggle before I905, but the bitterness was there. No sooner was the state compromised and disorganized by the Japanese victories, than twenty-nine millions' worth of property was burned by the peasants. In the October days the council of labor delegates ruled Petersburg. All the peasant and labor deputies in the Duma demanded expropriation of the nobility, expropriation without any indemnity even from the state. These and similar demands defeated the Russian revolution and restored to the tsar's government its power.

In modern representative government every proposed tax and every proposed law is disputed by the interests which will be affected. These disputes may be called class struggles, but they are struggles of a different character. They are not revolutionary, they are not pushed to the point of antagonizing all other interests; and in these struggles there gradually develops an appreciation of the various interests and of their actual power. What has proven itself necessary 
a posteriori soon becomes an a priori virtue; men fight, but they do so as citizens acknowledging the superiority of the interests of the commonwealth as a whole over their particular interests. Thus a larger patriotism develops-the patriotism of a truer democracy. All this has been clearly set forth by the friend and literary executor of Marx and Engels, Eduard Bernstein, who assuredly had no other reason for acknowledging this fading of class struggles and this growth of a nobler and more disinterested social spirit than his own experience and observation of political facts and tendencies during his long and honest political career. $^{52}$

"s "Regarding this 'historical' conception of Kautsky's I venture to make the 'commercial' remark that man has two souls, so to say, a double moral bookkeeping. He is placed in modern society as an individual, or a member of a group or class, more or less in opposition to the community, from which no one is exempt, not even the workman, so far is his ultimate good coincident with that of the community. Each individual, however, is at the same time a citizen,-for the modern state recognizes no fixed distinctions, - and as such necessarily develops interest in the commonwealth, even if he attempts to impose its cost on another class than his own. The opposing interests of the classes will fight it out partly on the battle-ground of economic competition (which includes the trade union struggle), and partly-and this in constantly greater degree-in the legislature. From the strife of class interests the common interest will slowly evolve, and the more prominent the common interest becomes the more democratic the commonwealth. With the advance of democracy the class struggle must gradually assume aspects different from those in a state where political class privilege prevails. There will still be strife, but it will be through speech, through the press, and through the ballot, and 
We are talking about the increase of peace and good-will on earth, but it will be pointed out to us that in this fair country class struggles are raging as never before. We shall be asked whether the comparison of the chronicles of our own days with the histories of the past does not justify Marx and the socialist doctrine. Class struggle has found its way even into American literature, in poetry and in art. Is not our social life characterized in the lines of William Vaughn Moody:

"From the patient and the low

I will take the joys they know;

They shall hunger after vanities and still an-hungered go;

Madness shall be on the people, ghastly jealousies arise;

Brother's blood shall cry on brother up the dead and empty skies."

all parties which bespeak the vote of democracy must pay tribute to the commion welfare. This naturally will not come to pass without hypocrisy, but hypocrisy in this instance is exactly the tribute which class egotism pays to the common interest, often enough with gnashing of teeth. Willingly or unwillingly, however, the ultimate result will be the same: class interest will give way, and the common interest gain in power. The law-giving power will at once grow stronger in its opposition to the strife of economic forces, and will eventually exert jurisdiction over what formerly was exposed to the blind struggle of particular interests." BERnstein, Sozialistische Kontroversen (Berlin, 1904), pp. 68, 69. 
Two distinct points are implied in such contentions. First, that class struggles characterize the American life of to-day and did not characterize it in the past; secondly, that the class struggle of the industrial proletariat is gaining in volume, power, bitterness and political significance.

If by class struggles we mean evidences of friction of various interests, they have perhaps increased in volume. This is only natural in a rapidly developing country with a rapidly decreasing amount of elbowroom. That friction of interests did not exist in this country in the past is, however, an erroneous impression caused by an optical illusion. Our point of view has shifted. At present we are increasingly inclined to look at politics and history from a social and economic point of view, and, as a result, we see what we are looking for-struggles between the several economic interests. Our conviction that class struggles are increasing is due in large measure to a more realistic and practical point of view in our political science.

The second implication, namely, that the proletarian class is growing in strength and in class consciousness and is marching towards victory, I am constrained to deny altogether.

Class struggle and proletarian class struggle in the Marxian sense are two very different conceptions. A struggle of farming interests with manufacturing interests is a class struggle. It has, however, no bearing upon the victory of the proletariat or upon the 
advent of socialism. The only class-conscious struggle that is of momentous significance to Marxian socialism is that of the industrial proletariat, and nowhere is this class weaker nor are its chances of development anywhere slighter than in these United States. There are many reasons for this.

First of all, the steady stream of immigrants of numerous races, creeds and tongues is bound to retard the growth of class solidarity. The radicals of old failed in their monumental attempt because of the confusion of tongues, and the tower of Babel remained unfinished. Our radicals of to-day cannot even begin with their new tower; the crowd is too motley, the diversity of its component elements too great; what it has in common is confusion, not solidarity.

Secondly, our modern industrial organization is of such a nature that it undermines proletarian class consciousness. John R. Commons expresses it admirably in his article on the subject: "Promotion, where speed is the standard, has rich possibilities compared with old forms of promotion based on skill. Under the older forms, workmen came into the various skilled trades by several side entrances of apprenticeship, and each trade had its narrow limits upward. Under the newer forms, the workmen nearly all come in at the bottom, and the occupations are graded by easy steps all the way to the top. The ambitious workman advances rapidly, and with every step his rate of pay increases and his work gets easier. But he remains all 
the time a part of a gang, and his earnings depend on the exertions of those below him. As he approaches the head of his gang he has the double job of a man who gets wages as a workman and profits on his fellow-workman. He begins to be paid both for his work and for making others work. Quite generally it will be found that the headmen of a gang are paid disproportionately high for the skill they are supposed to have. The difference is a payment, not for mechanical skill, but for loyalty. They keep their fellows up to the highest pitch of exertion and they stand by the company in times of discontent. Their promotion is not a mere outlet for agitation; it is a lid on the agitation of others. But there is still further room for promotion, when the workman becomes a foreman. superintendent or manager. Here he ceases manual work and keeps others at work. He gets a salary, often a bonus or a share in the profits, depending for its amount upon the work of his former fellows. Thus it is that a wise system of promotion becomes another branch of industrial psychology. If scientifically managed, as is done by the great corporations, it produces a steady evaporation of class feeling. I have often come upon fiery socialists and ardent trade unionists thus vaporized and transformed by this elevating process." ${ }^{33}$ This principle of promotion from one class to another is fatal to the organization of a pro-

"John R. Commons, "Class Conflict in America," The American Journal of Sociology, vol. xiii (Chicago, 1908), pp. 760, 76I. 
letariat in our democratic commonwealth, because it tends to leave the lower strata without able leaders. At the same time it carries fresh force and intelligence into that class which, according to the socialist theory, is bound to disappear.

In the third volume of Capital Marx shows that he is half conscious of the situation. Speaking of credit, he points out that credit permits the able man without capital to function as a capitalist; and he remarks that a class which readily takes into its own ranks the ablest men of the lower strata makes its rule more solid and more dangerous. ${ }^{54}$ This is obviously true; and it is equally true that nowhere are the doors of opportunity more widely open, that never was a capitalist class more ready to welcome into its ranks men of promise and ability, than in the United States. Such conditions are fatal to a proletarian movement. Where there is no prejudice against a man because he started as a laborer, the ex-laborer cannot be expected to adhere to the class from which he has emerged. His advice is: Do likewise; and his example is one of encouragement.

Under such conditions a proletarian movement is confronted by a peculiar dilemma. The man that is fit to be a leader, an organizer of the proletariat, is no longer himself a proletarian. His ability raises him above his class; he belongs potentially to another class. He is fit to be a successful manager of a mill;

84 Marx, Das Kapital, vol. iii, Part I (Hamburg, I894), p. 140. 
he can join the capitalist class at any time. And is there in this country so deep-seated a prejudice against personal and material success as to restrain a man from succeeding economically and socially? If labor in the United States is not content to be led by cheap men, it must find men actuated by more ideal motives and ready to make greater sacrifices than the political and social tone of this country authorizes it to expect.

But we shall be told that the test is in the results, and that trade unionism is growing. This statement at once raises the question: is trade unionism a proletarian class movement? This question is one which cannot be adequately discussed in a few pages. A few points, however, may be noted. The aim of trade unionism is to improve the conditions of the wageworker; the aim of socialism is to abolish wage labor. The Marxist expects the revolt of the proletarian class because of its increasing misery; he expects no revolt because of better conditions of existence. What the Marxist likes about trade unionism is that it organizes wage-workers and trains them in local and partial class struggles; what he dislikes in trade unionism is its exclusiveness, its refusal to take in more than a small portion of the proletarian class. A few months ago Kautsky's Erfurter Programm was translated into English under the title, The Class Struggle. There we read: "Far-sighted politicians and industrial leaders have not been slow to take advantage of 
this condition. To-day the worst enemies of the working class are not the stupid, reactionary statesmen who hope to keep down the labor movement through openly repressive measures. Its worst enemies are the pretended friends who encourage craft unions, and thus attempt to cut off the skilled trades from the rest of their class. They are trying to turn the most efficient division of the proletarian army against the great mass, against those whose position as unskilled workers makes them least capable of defense." ${ }^{55}$ The tendencies of American socialism and American trade unionism are so different that little love is lost between the two camps.

Moreover, the prospects of trade unionism itself are not wholly encouraging in this country. It has encountered and still encounters great difficulties. Commons writes in the article already cited: "Of the $6,000,000$ wage-earners mentioned, possibly $2,000,000$ are organized in unions. But the unions have practically disappeared from the trusts, and are disappearing from the large corporations as they grow large enough to specialize minutely their labor. The organized workmen are found in the small establishments like the building trades, or the fringe of independents on the skirts of the trusts; on the railways where skill and responsibility are not yet displaced by division of

${ }^{\circ}$ Kautsky, The Class Struggle, p. 182. The English translation differs from the German text (2d ed., Stuttgart, 1892), where the original of the passage cited will be found on p. 213 . 
labor; in the mines where strike-breakers cannot be shipped in; on the docks and other places where they hold a strategic position. While the number of organized workmen shows an increase in these directions, it shows a decrease in the others. It is in these organized industries that the class conflict appears, and there the lines are drawing tighter. It is there that employers' associations are forcing employers into line and are struggling to do for the medium employer what the trust does without association. But most of the unions in question are not unions of a class. They are unions of a trade or a strategic occupation." 56

We are forced to the conclusion that the proletarian class movement is in this country a negligible quantity. In all the criss-cross class struggles capital is signally victorious. The victories of corporate wealth have been so overwhelming that what capital is facing today is a coalition of all smaller interests in the name of democracy.

We all know that the Constitution, as interpreted by the courts, has given capital a strong position. The fourteenth amendment, intended for the benefit of the negroes, protects capital from so-called "class legislation." In the opinion of many Americans, the constitutional position of capital is impregnable and the sovereignty of the state is denied; but, if so, it is so from a static point of view only. Social life is any-

"J. R. Commons, "Class Conflict in America," The American Journal of Sociology, vol. xiii, p. 759. 
thing but static. I therefore do not agree with President Hadley's statement that "the fundamental division of powers in the Constitution of the United States is between voters on the one hand and property owners on the other." ${ }^{57}$ In the long run the constitution of a country means precisely what the voters want it to mean. These voters of course represent divergent interests and strife is inevitable; but so is its democratic outcome-a just balance of interests.

" And rival storms abroad are surging From sea to land, from land to sea, $A$ chain of deepest action forging Round all, in wrathful energy. There flames a desolation, blasing Before the thunder's crashing way; Yet, Lord, Thy messengers are praising The gentle movement of Thy day." " 8

${ }^{67}$ Hadley, "The Constitutional Position of Property in America," The Independent, April 16, 1908.

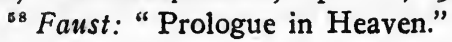




\section{CHAPTER $\mathrm{X}$}

\section{THE THEORY OF CRISES}

IN Marx's map of life all the paths and all the byways led to the great social revolution; all the streams and all the currents were hurrying on to the great cataract, the cataclysm of the capitalist order of society. In his scheme of events Marx conceded us no chances whatever. No matter from what angle we might view our future, our doom was foreordained. The concentration of industry and agriculture, the socialization of all production, the massing of all wealth and capital in the hands of the few; the disappearance of the middle class, the steadily growing antagonism between the two remaining classes, the increasing misery of the proletariat and the rapid approach of a life and death struggle between labor and capital; the overwhelming legions of the proletariat, and the dwindling numbers of the capitalistic magnates-all these tendencies were making socialism inevitable. In this reasoning there seemed to be no break or flaw; every link in the chain was forged securely; and, with the faith that Marx had in the tendencies that he described, the social revolution and the complete triumph of socialism seemed equally assured. 
Independently of all these tendencies, however, seeds of corruption were disintegrating our social fabric, the walls of our city were shaking, and they were to fall and crumble before new life was to spring up on their ruins. Let me quote again from the Communist Manifesto: " Modern bourgeois society with its relations of production, of exchange and of property, a society that has conjured up such gigantic means of production and of exchange, is like the sorcerer who is no longer able to control the powers of the nether world whom he has called up by his spells. . . . It is enough to mention the commercial crises that by their periodical return put on its trial, each time more threateningly, the existence of the entire bourgeois society. . . . In these crises there breaks out an epidemic that, in all earlier epochs, would have seemed an absurdity-the epidemic of overproduction. Society suddenly finds itself put back into a state of momentary barbarism; it appears as if a famine, a universal war of devastation had cut off the supply of every means of subsistence; industry and commerce seem to be destroyed; and why? Because there is too much civilization; too much means of subsistence, too much industry, too much commerce. The productive forces at the disposal of society no longer tend to further the development of the conditions of bourgeois property; on the contrary, they have become too powerful for the conditions by which they are fettered. . . The conditions of bourgeois society are too 
narrow to comprise the wealth created by them. And how does the bourgeoisie get over these crises? On the one hand by enforced destruction of a mass of productive forces; on the other, by the conquest of new markets, and by the more thorough exploitation of the old ones. That is to say, by paving the way for more extensive and more destructive crises, and by diminishing the means whereby crises are prevented." 1 The anarchy of production in our competitive system is bound to destroy the whole system. With striking vividness Engels pictured to us, in his earliest as well as in his latest writings, this growing revolt of the productive forces against the forms of production. The idea he got either from Fourier or from Simonde de Sismondi, whose master mind anticipated this theory in many details. ${ }^{2}$ But whatever may be the genealogy of the theory of crises, the fact remains that as early as 1844 and I 845 , both in his book on the Situation of the Laboring Class in England and in his speech at the conferences on communism at Elberfeld, Engels portrayed the steeplechase of competitive industry that leads invariably and inevitably to crises

${ }^{2}$ Marx and Engers, Manifesto of the Communist Party (Chicago, Charles H. Kerr and Company), pp. 21, 22.

- Both the overproduction and underconsumption sides of the theory, the conquest of new markets as a means of overcoming commercial depression; the increasing magnitude of each recurring crisis-these things had been pointed out already in the twenties by one of the greatest and most neglected of economists, Sismondi. C $f$. his Nouveaux principes, etc., pp. 329, 36r, 372. 
of overproduction. The manufacturer, Engels declared in 1845 , does not know the consumer or his needs; he manufactures not knowing where his product will be shipped, nor does he know how much his foreign competitors are manufacturing for the same market; he is manufacturing blindly; and his sole consolation is that his competitors are no better informed, and have to act in the same way. ${ }^{3}$ The obvious result of such anarchy in production is overproduction and the commercial crisis. With the extension of industry the magnitude of the crises and the misery of the unemployed increase. And as planless competitive production inevitably leads to crises, so, and with equal certainty, the existing capitalist organization will produce the social revolution. This is as certain as a mathematical deduction from axiomatic premises. ${ }^{4}$

In Engels's "Anti-Dühring" (reprinted in his Socialism, Utopian and Scientific), these views are further elaborated: "The enormous expansive force of modern industry, compared with which that of gases

s Engels's speech in Elberfeld, reported in Rheinische Jahrbücher für gesellschaftliche Reform (Hermann Püttman, Darmstadt, 1845), vol. i, pp. $47,48$.

4 "You see therefore, gentlemen, that what in beginning I explained as a general principle holds also in the particular instance, especially in regard to competition,-namely, that the inevitable consequence of our existing social conditions will under all circumstances and in all cases be social revolution. With the same certainty with which from given mathematical premises we can deduce a new equation, we can infer from the existing economic conditions and the principles of political economy an impending social revolution." Ibid., pp. 78, 79. 
is mere child's play, appears to us now as a necessity for expansion, both qualitative and quantitative, that laughs at all resistance. Such resistance is offered by consumption, by sales, by the markets for the products of modern industry. But the capacity for extension, extensive and intensive, of the markets, is primarily governed by quite different laws, that work much less energetically. The extension of the markets cannot keep pace with extension of production, the collisions become periodic." 's Here we have a precise theoretical statement of the Marx-Engels conception of crises; and it is this theory that we find in Marx's Capital. The crises of overproduction are not simply Fourier's "plethoric crises "; ${ }^{\circ}$ they are manifestations of the incongruity inherent in capitalist production. Capitalist production must expand more rapidly than capitalist distribution can permit consumption to expand, and the disproportion constantly increases by reason of the steady increase of the productivity of human labor. Hence overproduction and resulting liquidation-an industrial cycle that ends where it began, in the ditch of the commercial crisis. How fundamental this conception is to Marx is shown in his theory of wages and of the industrial reserve army.

- Engrrs, Socialism, Utopian and Scientific (New York, 1901), p. 4 I.

- Engels writes: "And the character of these crises is so clearly defined, that Fourier hit all of them off when he described the first as 'crise pléthorique,' a crisis from plethora." Socialism, Utopian and Scientific, p. 42. 
Expansion and contraction of production are taken for granted as the characteristic features of capitalistic production.

There has been considerable discussion of the question whether Marx's theory of crises is not identical with Rodbertus's underconsumption theory. In the second and third volumes of Capital we find some apparently contradictory statements. While the second volume ridicules the underconsumption theorists and the followers of Rodbertus, ${ }^{7}$ the third volume emphasizes, as the basic reason for all crises, limited con-

7 "It is mere tautology to say that crises are due to lack of consumers who are able to pay for what they want, or of consumption supplied with means. The capitalistic system knows no consumption which does not pay except that sub forma pauperis, or of knaves. That wares are unsalable means simply that there are no purchasers to pay for them, and consequently no consumers. ... If, however, one wishes to lend to this tautology an appearance of deep import by saying that the working class retains too small a portion of its own product, and that this evil will consequently be remedied as the class receives a larger share and its wages increase, it need only be remarked that crises in each instance are engendered in times in which wages as a rule are rising and the working class is actually retaining a larger share of the part of the yearly products which is destined for general consumption. This period ought, on the contrary-from the point of view of these astute gentlemen who pride themselves upon their simple common sense (!) - to do away with crises. It appears, therefore, that capitalistic production includes conditions independently of any beneficent or evil purpose, and that the relative prosperity of the working classes only temporarily permits these conditions, and always, to be sure, merely as the forerunner of a crisis. (Ad notam für etwaige Anhänger der Rodbertus'schen Krisentheorie. F. Engers.)" MarX, Das Kapital, vol. ii (2d ed., Hamburg, 1893), pp. 385, 386. 
sumption, due to poverty of the masses, and the tendency of capitalist production to develop its productive forces as if the capacity of the consumer were not limited by poverty. ${ }^{8}$ Bernstein ${ }^{\circ}$ tries to explain the difference in these statements by the lapse of time, the interval of thirteen or fourteen years, between the writing of the second and third volumes of the Capital. But he overlooks a note in the second volume which contains practically the same statement as that cited above from the third volume. ${ }^{10}$ In so far as there is a contradiction, it already existed in the two statements of the second volume. If, however, we lay undue stress on faulty or inadequate explanations advanced by Marx, we shall fail to comprehend his central idea, which is obvious and clear: the antithesis

- "But as matters stand, the reproduction of capital invested in production depends largely upon the consuming power of the non-producing classes; while the consuming power of the laborers is handicapped partly by the law of wages, and partly by the fact that it can be exerted only so long as the laborers can be employed with profit to the capitalist class. The ultimate cause of all real crises always remains the poverty and restricted consumption of the masses as compared with the tendency of capitalist production to develop the productive forces in such a way that only the absolute power of consumption of the entire society would be their limit." Marx, Capital, vol. iii, English ed., p. 568.

- Bernstern, Evolutionary Socialism (New York, 1909), p. 75. 10 "The periods in which capitalist production exerts its full capacity regularly appear as the periods of overproduction, because the forces of production can never operate so as not to produce more values than can be marketed and realized. The sale of commodities, the realization of capital invested in commodities, i.e., the realization of surplus value as well, is, how- 
between the almost unlimited expansive force of production and the limited power of consumption. Unequal distribution, poverty and limited power of consumption were quite as marked in past ages as in the capitalist era, but in past ages the forces of production were also very limited. What characterizes capitalist production is the altogether disproportionate development of the forces of production as well as the accumulation of capital that yearns for further accumulation and therefore refuses to remain idle. Hence the constantly growing overproduction, which is bound to become chronic and incurable, and to lead to the cataclysm of our present mode of production. It is a striking example of Marx's revolutionary dialectics, which "includes in its comprehension an affirmative recognition of the existing state of things, at the same time also the recognition of the negation of that state, of its inevitable breaking up; because it regards every historically developed social form as in fluid movement, and therefore takes into account its transient nature not less than its temporary existence; because it lets nothing impose upon it, and is in its essence critical and revolutionary. The contradictions inherent in the movement of capitalist society impress themselves upon the practical bourgeois most strikingly in the changes of the periodic cycle through which

ever, limited not by the needs of society as a whole, but by the needs of a society the greater part of which always is and always must remain poor." MARx, Das Kapital, vol. ii, p. 289. 
modern industry runs, and whose crowning point is the universal crisis." 11

In their faith in the approaching dies irae Marx and his followers did not differ from the Second Adventists. Nearly every commercial depression since $185^{\circ}$ was heralded by them as the beginning of the end of capitalism. If they did not, like the Millerites, attire themselves in white ascension robes to meet the coming of the Day, it was because their ritual was different. They did notify the proletarians of all lands to "get ready." In 1896 the International Socialist Congress passed the following resolution: "The economic and industrial development is going on with such rapidity that a crisis may occur within a comparatively short time. The Congress, therefore, impresses upon the prolateriat of all countries the imperative necessity of learning, as class-conscious citizens, how to administer the business of their respective countries for the common good." 12 Socialist literature, both popular and scientific, has constantly dwelt on the coming collapse of the capitalist mode of production, for which conclusive proofs were always at hand. Some of these writings are both brilliant and eloquent, especially those of Kautsky. ${ }^{13}$ The fact, however, remains that

11 Marx, Capital (fourth English ed., 189r), pp. xxx, xxxi.

12 Bernstein, Evolutionary Socialism, p. 80.

${ }^{13}$ Kautsky reproduces Marx's theory so clearly and in so popular a form that I venture to quote some passages:

"The revolution in the machinery of production goes on uninterrupted; the fields that it invades are ever more numerous. 
the imminent cataclysm which the Marxists have been prophesying for sixty odd years has failed to occur; and it really seems time for them to explain why it is still postponed. Each time the Millerites were disappointed, they revised their exegeses of Daniel and of Revelation.

Marx's theory of crises has the faults that characterize all Marxian theories. On the basis of facts not always rightly interpreted, tendencies of social life are formulated. Each of these tendencies, invariably destructive to the general welfare, is expected to persist and to reach its highest potency unchecked and unhampered. Society is not expected to protect itself, to adjust itself or to meet situations as they arise-a

Year after year new branches of industry are captured by capitalist large production, and consequently the productivity of labor grows incessantly, and at an ever increasing rate. Simultaneously with this the accumulation of new capital proceeds without interruption. The intenser the exploitation of the single laborer and the larger the number of the exploited laborers, the larger also grows the quantity of the surplus and the mass of wealth that the capitalist class can lay by and apply as capital. The capitalist system, therefore, cannot remain stationary; its constant expansion and the constant expansion of its market are a vital necessity to it; to stand still is death. While formerly, in the days of handicraft and small farming, the country produced year in and year out a quantity of wealth, which, as a rule, increased only with the increase of population, the capitalist system, on the contrary, is from the start dependent on an incessant increase of production; every stoppage indicates a social malady which grows more painful the longer it lasts. Thus together with the periodical incentives to increase of production brought on by the periodical extensions of the market, there is a permanent pressure in this 
childish conception of historical life. Life is full of recuperative powers; it has more antidotes than there are poisons; it has counter-tendencies for every tendency; or, as our genial Dr. Crothers puts it, "there is one tendency which all tendencies have in common, that is to develop counter-tendencies. There is, for example, a tendency on the part of the gypsy-moth caterpillar to destroy utterly the forests of the United States. But were I addressing a thoughtful company of these caterpillars I should urge them to look upon their own future with modest self-distrust. However well their program looks upon paper, it cannot be carried out without opposition. Long before the last tree has been vanquished, the last of the gypsy-moths may

direction inherent in the capitalist system of production itself. This pressure, instead of being brought on by the extension of the market, compels the latter to be pushed constantly further. ... The wonderful development of transportation renders from year to year a completer exploitation of the market possible; but this tendency is counteracted by the circumstance that the market steadily undergoes a change in those very countries whose population has reached a certain degree of civilization. Everywhere the introduction of the goods of capitalist large production extinguishes the domestic system of small production and transforms the industrial and agricultural laborers into proletarians. This produces two important results in all the markets that are counted upon to absorb the surplus products of capitalist industry: first, it lowers the purchasing power of the population and thereby counteracts the effect of the extension of the market; and, secondly, and more important, it lays there the foundation for the capitalist system of production by calling into existence a proletarian class. Thus capitalist large production digs its own grave. From a certain point onward in its development every new extension of the market 
be fighting for its life against the enemies it has made." 14

In the first place, the fundamental assumption that capitalist production cannot get along without foreign markets, that the conquest of new and further exploitation of old foreign markets is the capitalist method of overcoming crises-all these sweeping statements are unwarranted. Take Germany as an illustration. In spite of the colossal development of German industry, the domestic market is absorbing a growing proportion of the sum total of its production. In the period r880I900, notwithstanding the enormous extension of Germany's iron and coal industry, the export of iron sank from 29.3 to 7.8 per cent of the total production, and the export of coal from 1 I to $7 \cdot 3$ per cent. ${ }^{15}$

Further, it is admitted by Engels himself that crises are not increasing in frequency or in magnitude, but are far less disturbing than they were half a century ago. Even in the third volume of Capital, which still cherishes the roseate hope of a "Weltkrach" ("cata-

means the rising of a new competitor. . . . For some time past the extension of the markets has not kept pace with the requirements of capitalist production. The latter is, consequently, more and more hampered and finds it increasingly difficult to develop fully the productive powers that it possesses. The intervals of prosperity become shorter; the length of the crises ever longer." Kautsky, The Class Struggle (Chicago, 1910), pp. 82-85.

${ }^{14}$ Crothers, By the Christmas Fire, pp. 6I, 62.

${ }^{15}$ Tugan-Baranowsky, Theoretische Grundlagen des Marxismus (1905), pp. 231, 232. Cf. Sombart, Die deutsche Volkswirthschaft im neunzehnten Jahrhundert (1903), pp. 430, 431. 
clysm "), we are told that the modern development of the international market has abolished most of the old incubators of crises, and has generally diminished their danger - a most important admission, which really nullifies the whole prophetic theory as originally presented by Marx and Engels. ${ }^{16}$ And in his Socialism, Utopian and Scientific, in which the cataclysm plays none too modest a part, Engels shows that he is quite aware of the fact that overproduction can be checked and output regulated without any preceding social revolution. He tells us how producers on a large scale in any given country unite in a pool for the purpose of regulating production, how they determine the total amount of the output, and parcel it out among themselves at prices fixed beforehand. $\mathrm{He}$ tells us, further, that if pools of this kind, gentlemen's agreements, etc., show tendencies of breaking up, a still

20 "The colossal extension of the means of transportation and communication-seagoing steamers, railroads, electric telegraphs, the Suez Canal-have made a real world market a fact. The monopoly o: industry formerly enjoyed by England has been matched by a number of competing countries; infinitely greater and more varied fields have been opened in all parts of the world for the investment of superfluous European capital, so that it is much more widely distributed, and local overspeculation may be more easily overcome. By means of these things, the old breeding grounds of crises and opportunities for the growth of crises have been eliminated or strongly reduced. At the same time competition in the internal markets recedes before Kartels and trusts, while it is restricted in the international market by protective tariffs, with which all great industrial countries, England excepted, surround themselves." MARX, Capital, vol. iii (English translation), p. 575, Engels's note. 
greater concentration of association develops. The bulk of a given industry is then turned into a trust, a gigantic joint-stock company. "In this trust, freedom of competition changes into its very oppositeinto monopoly; and the production without any definite plan of capitalist society capitulates to the production upon a definite plan of the invading socialistic society. Certainly this is so far still to the benefit and advantage of the capitalists. But in this case the exploitation is so palpable that it must break down. No nation will put up with production conducted by trusts, with so barefaced an exploitation of the community by a small band of dividend-mongers." ${ }^{17}$

Granting for argument's sake that trusts lead to socialism, what has happened to the elaborate MarxEngels theory of crises, and to the inevitable cataclysm accompanied by the trumpets of the social revolution? What has happened to the inner contradiction between the ever-expanding forces of production and the limitations of consumption? Have not all these elaborate, even if unfounded, theories been abandoned, exchanged for the simple faith that trusts may usher in socialism? Is not this a complete change of program? What has become of universal crisis, complete breakdown of capitalist production, social revolution, dictatorship of the proletariat, general expropriation, and blood and thunder all along the line?

Every tendency that Marx and Engels confided in ${ }^{17}$ Engers, Socialism, Utopian and Scientific, p. 44. 
has been checked, retarded, deflected or reversed. Industry has not concentrated to any such extent as the fathers of scientific socialism expected. Agriculture shows tendencies towards decentralization. The concentration of wealth and proletarization of the middle class has proved a fable; the moderate incomes are steadily increasing in number. The idea of the growing misery of the proletariat is abandoned, in view of facts that prove the opposite; the class struggle, instead of increasing, is as a whole diminishing. Commercial crises, that were to increase till they destroyed like an earthquake our whole industrial organization, are admittedly abating their fury. The argument is being shifted back to concentration of industry and agriculture, a subject that I have discussed in Chapter IV.

Theories of crises more tenable than the Marxian cataclysmic theory have been elaborated, ${ }^{18}$ but they lie outside of the present inquiry. What interests us is the fact that it is not our industrial society but the Marxian theory that has broken down. Among the American socialists there seems to be a tendency to forget this theory. We are told by Miss Hughan that,

18 Tugan-Baranowsky, Theoretische Grundlagen des Marxismus (Leipzig, 1905), pp. 210 et seq. Bouniatian, Wirtschaftskrisen und Ueberkapitalisation (München, 1908), perhaps the best book on the subject. TUgan-Baranowsky, Studien zur Theorie und Geschichte der Handelskrisen in England (Jena, 1901), pp. I-37, 174-254. LeSCURE, Des Crises générales et périodiques de surproduction (1907), pp. 455 et seq. 
according to Lucien Sanial, the acknowledged authority on crises among American socialists, "Marx's theory was a valid explanation . . . of all crises until r880. Since that time we have entered upon the stage of concentration in capitalism, where the cause of the crisis is no longer industrial but commercial and financial. The investigator must now seek for the factors which in the course of economic evolution have so developed as to modify the financial and commercial circumstances; he will then find only a partial and constantly less adequate explanation of each successive crisis in the overproduction theory of Marx." 18 Another leader of American socialism, a member of the national committee, seems to have abandoned Marx to the point of stating that "each and every panic that has occurred has not the same basis." 20

The Marxian theory of crises as originally formulated, with its announcement of the inherent doom of the capitalist organization of society, might therefore properly be declared to be both obsolete and untenable. The social revolution with the dictatorship of the proletariat, which was to follow or accompany the great crisis, still lingers in the minds of those who have long since abandoned all hope of the cataclysm. Let us therefore examine this social revolution.

10 Hughan, The Present Status of Socialism in the United States (I9II), chapter vii and passim.

${ }^{30}$ Ibid. 


\section{CHAPTER XI}

\section{THE SOCIAL REVOLUTION AND THE IN- EVITABLE CATACLYSM}

FEw words have been so assiduously interpreted by the so-called Marxists as the word " revolution." Interpretation was not infrequently necessary. The conquest of political power through an armed uprising, preached openly, brought the agitator in continental Europe before the courts, under the charge of treason. In pleading his case he naturally tried to tone down the meaning of the word " revolution." 1

In preaching revolution in a democracy like ours the agitator is confronted with still greater difficultieshe is not listened to by intelligent people. In a democracy the will of the majority is supposed to rule. There can be, therefore, no occasion for a revolution, unless it be a revolution of a minority against the will of the majority. At present there is much criticism of the judiciary and even of the Constitution; but it comes in the main from an irritated minority. Legislative acts could not be vetoed by the courts if it were the determined will of the majority of the people

${ }^{2}$ Hochverrats-Prozess wider Liebknecht, Bebel, Hepner (Berlin, 1894), pp. 71, 457, 675-679. 
that the courts should not have that power. The fact is that the majority of the people have greater confidence in the courts than they have in the legislative bodies. Whatever the legal theory may be, in a democracy the decisions of the courts cannot in the long run antagonize the prevailing public sentiment. Revolutionary propaganda in this country and in England is therefore bound to fall on deaf ears.

Yet Marx laid great stress on the revolution. His socialism is international revolutionary socialism. It is its adherence to the revolutionary principle, its insistence upon the capture of political power, the dictatorship of the proletariat, the overthrow of the present economic organization of society, that gives it a peculiar stamp of its own. No matter, therefore, how much Marx may be sugar-coated, the word " revolution" cannot be stricken from the Marxian dictionary. The word may, of course, be used in various senses. There has been an industrial revolution, there have been revolutions even in fashions of hair-dressing. Marx often uses the word revolution in other senses than that attributed to it in politics; but in order to expurgate political revolution from his original doctrine, it would be necessary to mutilate his writings beyond the possibility of recognition. It was not as an economist but as a theorist of revolution that Marx started. All his economic and philosophical inquiries were prosecuted to find reasons for the assumptions 
with which he started, and proofs of the conclusions which he had already reached.

One might paraphrase Kant's "Wie sind synthetische Urteile a priori möglich?" and ask: "How is a social revolution possible?" and one would have in a nutshell the real purpose of Marx's investigation. His single theories are instrumentalities, his many learned observations by-products of the central operation of his mind. Back of his most abstract reasonings, his seemingly purely scientific considerations, there is a tremendous emotional appeal. It is not an ethical appeal, it is simply a statement that certain things which he profoundly desires will assuredly take place-a statement not subject to debate or discussion. Its finality is majestic. And whatever that appeal may be to us, for the countless, nameless legions of the proletariat there is honor, there is duty, there is promise, there is life! Is it life at its best and highest? is an idle question. It is life that meets death with a smile; " mourir en combattant." This treasure of the French Revolution became the heritage of the forties, and Marx's soul lived on it lavishly.

"With a deathless scorn in my dying breath, In my hand the sword still cherished; 'Rebellion' still for my shout of death." 2

"From Freiligrath's "Abschiedswort" on May 19, 1849, in the Neue Rheinische Zeitung, No. 301. The English version cited is by Ernest Jones. Cf. Spargo, Karl Marx (1910), p. I65, where the whole poem is quoted. 
Translate these lines of Freiligrath into better prose and one has Marx's valedictory. No matter what work of Marx's one reads, one will find there no attempt at a disguise. There is the vision of the great revolution, and toward it lies his course. Only after the great social revolution, which will abolish all classes and class-antagonisms, can social evolutions cease to be political revolutions. Until then the last word of social science will ever be: "Le combat ou la mort; la lutte sanguinaire ou le néant." 3 In the last number of the Neue Rheinische Zeitung ${ }^{4}$ he urges revolutionary terrorism. ${ }^{5}$ In other writings he tells us that " revolutions are the locomotives of history." " True, a revolution is an act of destruction, it abolishes old relationships; but for that very reason "socialism without a revolution is impossible." 7 Revolution is the breath of the Communist Manifesto. Let the ruling classes tremble; the proletarians have nothing to lose but their chains. It is in revolution that all the theories of Marx's Capital converge. Its supreme moment is when "the knell of capitalist private property sounds. The expropriators are expropriated." 8

- Marx, Misère de la philosophie (Paris, 1847), p. 178.

- No. 301, May 19, 1849.

- For further quotations see Simkнoviтch, "Die Krisis der Socialdemokratie," Conrad's Jahrbücher, vol. xvii (1899). Cf. also HaMmacher, Das philosophisch-ökonomische System des Marxismus (Leipzig, 1909), pp. 91-94.

- MARx, Die Klassenkämpfe in Frankreich (Berlin, 1895), p. 90.

'MARX und ENGELS, Literarischer Nachlass, vol. ii (1902), p. 59.

- Marx, Capital, vol. i (fourth English ed.), p. 789. 
It is thus a philosophy of revolution that Marx presents. In this philosophy of revolution, curiously enough, either the philosophy stamps the idea of a revolution as a feverish dream, or the revolution upsets the philosophy and makes it ridiculous. Marx, the founder of scientific socialism, the deadly critic of utopianism, is himself a revolutionary utopian; and it is his revolutionary utopia that has captured the masses and converted them to anti-utopian scientific socialism!

Let us take, for example, the dictatorship of the proletariat and its rôle in the social revolution. "The proletariat will use its political supremacy to wrest, by degrees, all capital from the bourgeoisie, to centralize all instruments of production in the hands of the state, i.e., of the proletariat organized as the ruling class, and to increase the total of productive forces as rapidly as possible. Of course, in the beginning, this cannot be effected except by means of despotic inroads on the rights of property, and on the conditions of bourgeois production; that is, by means of measures, therefore, which appear economically insufficient and untenable, but which, in the course of the movement, outstrip themselves, necessitate further inroads upon the old social order, and are unavoidable as means of entirely revolutionizing the mode of production." 9

Babeuf or Blanqui might have written this passage;

- Communist Manifesto, pp. 44, 45. 
it would have been quite in keeping with their general point of view-that of conspiracy and forcible overthrow. They believed that the socialist commonwealth could be decreed at any time by the victorious proletariat; all that was required was political power. How many a time did Marx and Engels declare such ideas to be dangerous utopias, that could lead to nothing but demoralization and disaster! Marx could not look upon them differently so long as he regarded his economic interpretation of history as the fundamental proposition of his doctrine. No dictatorial decrees of the victorious proletariat, no despotic measures, no concentrated action of all the guillotines in the world could centralize the instruments of production. Socialism is possible only when in the course of economic development all production has become concentrated and socialized. Hence Marx affirms: "No social order ever disappears before all productive forces for which there is room in it have been developed; and new higher relations of production never appear before the material conditions of their existence have matured in the womb of the old society." 10 What then can the dictatorship of the proletariat accomplish so long as production remains decentralized? The fabrication of a plan for a socialist commonwealth, and its introduction through a successful overthrow, Marx regarded as utopias, and he denounced

${ }^{10}$ Marx, A Contribution to the Critique of Political Economy (Stone's translation), p. 12. 
the preaching of such doctrines as "empty, conscienceless play with propaganda." These are the words which Marx addressed to Weitling! ${ }^{11}$ and yet Marx was himself guilty of that for which he reproached Weitling.

Marx and Engels had learned a great deal from experience. The preface to the Communist Manifesto admitted that the Paris commune had taught them that "the working class cannot simply lay hold of the ready-made state machinery and wield it for its own purposes." 12

There is no doubt whatever that the revolutionary element in Marx's writings was, even if unconsciously, taken over bodily from the older revolutionary socialists like Blanqui. There is equally no doubt of its being in complete contradiction to the economic interpretation of history. A revolution could not create a socialist state; it could proclaim it only if economic development had already created it. How then could so thorough a thinker as Marx be so persistently guilty of so glaring a contradiction in theory?

11 "Tell us, Weitling, you who with your communistic propaganda have made so much noise in Germany, and have attracted so many laborers, ... . with what arguments do you defend your social revolutionary agitation, and upon what do you intend to base your agitation in the future? . . . To appeal in Germany to the workingmen without strictly scientific ideas and concrete doctrine is tantamount to an empty-headed and conscienceless play with propaganda." Die Neue Zeit, vol. i (1883), p. 239.

${ }^{13}$ Communist Manifesto, p. 10. 
I believe that the real explanation is in his " dialectics," in his Hegelian logic, or rather in the dialectic process that among the Hegelians took the place of logic. It was a mode of thinking that proceeded only by revolutions, by negations of negations, by development through antitheses, by quantitative changes becoming qualitative. Antagonism was the driving force. Development consisted in constant rebellion of elements, in a series of cataclysms. To Engels this dialectic method was a fetish. Note for example the way in which he summed up the economic tendencies: "The antagonism between socialized production and capitalist appropriation manifests itself as the antagonism of proletariat and bourgeoisie ... it presents itself as an antagonism between the organization of production in the individual workshop and the anarchy of production in society generally. ... When the economic collision has reached its apogee, you have the mode of production in rebellion against the mode of exchange, i.e., the crisis and finally the social revolution." 13

This social revolution changes even the quality of the law of history. Economic and historical necessity is no more. "It is the ascent of man from the kingdom of necessity to the kingdom of freedom." 14 Translated into philosophical language, this means that causality ceases!

\footnotetext{
"ENGers, Socialism, Utopian and Scientific (1901), pp. 35, 38, 42. 
This passage helps us to see how the economic interpretation of history was apparently reconciled with the revolutionary conception. The historical process is a process of constant change, because of its inner antagonisms, which grow till they overcome each other by force, forming new and higher elements which in their turn confront new and growing antagonismsand so on indefinitely. The greater the antagonism, the nearer is the revolution. Marx's belief therefore was: the worse the better. Hence his dislike for reforms, for ameliorations that weaken antagonisms. The closing sentences in his speech on free trade strikingly illustrate this viewpoint. "Generally speaking," says Marx, "the free trade system is destructive. It breaks up old nationalities and carries the antagonism between proletariat and bourgeoisie to the uttermost point. In a word, the system of commercial freedom hastens the social revolution. In this revolutionary sense alone, gentlemen, I am in favor of free trade." 18 But with or without free trade, the revolution is inevitable-and why? Because society is divided into antagonistic classes. "The antagonism between the proletariat and the bourgeoisie is a struggle between class and class, a struggle which, carried to its highest expression, is a complete revolution." 18

Orthodox Marxists adhere to the revolutionary and

${ }^{26}$ Reprinted as appendix iii in the English edition of MARX's Poverty of Philosophy (London, 1900), p. 195.

10 Ibid., p. 159. 
cataclysmic doctrine. Kautsky, after giving us various analogies from natural history and depicting the act of birth as a revolution and catastrophe, ends by affirming "that as each animal creature must at one time go through a catastrophe in order to reach a higher stage of development (the act of birth or the breaking of a shell), so society can only be raised to a higher stage of development through a catastrophe." ${ }^{17}$ Dr. Luxemburg tells us that without the cataclysm of capitalism (i.e., the final crisis and social revolution) the expropriation of the capitalist class is impossible. The cataclysm, therefore, is the cornerstone of scientific socialism; with its removal there is nothing left of socialism. ${ }^{18}$ This is quite true, but it only proves that socialism, scientific or otherwise, has really no leg left to stand on. Let us examine its predicament.

We have seen that the hoped-for universal crisis, the collapse of capitalist production, might as well be eliminated. The untenability of this theory is admitted. The cataclysm is therefore reduced to the operation of the social revolution. Here again, however, Marx becomes involved in no end of difficulties

${ }^{17}$ Kautsky, The Social Revolution (Chicago, 1905), p. 20.

18 " As, however, the cataclysm of the bourgeois society is the cornerstone of scientific socialism, so the removal of this cornerstone would logically lead to the breakdown of the entire socialistic conception. . . . Without the collapse of capitalism the expropriation of the capitalist class is impossible." LUXEMBURG, Sozialreform oder Revolution (Leipzig, I899), p. 56. 
due to internal contradictions. The economic interpretation of history and the social revolution as an organizer of a new system of production cannot live together in the same house. The economic development is the foundation; law, politics, ideologies are superstructures. The foundation cannot be changed by the superstructures; on the contrary, the latter have to adjust themselves to the basis. This economic foundation may present a socialized and absolutely concentrated mode of production; the superstructure - the old law-may then be adjusted to the new economic requirements. Marx told us that the tendencies of existing society lead inevitably to concentration, socialization, proletarization, etc., which are forming a new economic foundation and will therefore produce a new legal superstructure-a socialist commonwealth. But we have seen that Marx was mistaken in his view of tendencies. The economic foundation for a socialist state does not exist, and there is no evidence that it ever will exist. On the other hand, revolutionary ideologies, bloody street fights, can never create a new economic basis.

And now let us look into the contradictions of the so-called dialectics of Marx and Engels. Granted that there is nothing fixed, nothing constant but the constancy of change. Marx assumes this; yet he is constantly operating with logical concepts, which are in their very nature unchangeable, inflexible, permanent and constant. If $a$ is $a$, it cannot be $a+c$ or $a-c$. 
Yet in the historical process that presupposes constant change, $a$ cannot remain the same $a$ as it was at the start. To make this concrete: Marx is dealing with classes, tendencies, etc. But from his own viewpoint his classes cannot help changing in character. The same thing is true about all his concepts, whether they are " crisis," "capitalism," " concentration" or " revolution." Yet while the historical process is battering, changing or even destroying the inner content of all these concepts, the Marxian socialist operates with them as with absolute and unchanging entities and works out "scientifically," by negation of the negation, our distant future! ${ }^{10}$

Not only has time changed the meaning of the concepts with which Marx and Engels operated, but the authors of revolutionary socialism themselves underwent a change and admitted that history had convicted them of error. Marx had little respect in his later years for Revolutionsspielerei; ${ }^{20}$ and Engels in

${ }^{10}$ Any one interested in the philosophical and logical aspects of the Marxian theory of development should not fail to read Peter von Struve, "Die Marxische Theorie der sozialen Entwicklung," in BRAUN's Archiv für soziale Gesetzgebung und Statistik, vol. xiv (1899), pp. 658-704, where this line of thought is further developed. See also Hammacher, Das philosophisch-ökonomische System des Marxismus (Leipzig, 1909), and UnTERMANN, Die logischen Mängel des engeren Marxismus (München, 1910); Stammler, Wirtschaft und Recht, 2d ed. (Leipzig, 1906); and MasaryK, Die philosophischen und soziologischen Grundlagen des Marxismus (Wien, 1899).

30 "The violent suppression of a revolution leaves behind in the minds of its participants, especially of those who have been 
1895 described his and Marx's early revolutionary conceptions as illusions, and admitted that history not only had proved them to be wrong, but also had changed all the conditions of class struggle. If the victory of the proletariat in street fights was of rare occurrence in the past, it has, under modern conditions, with the present military technique, with railroads and telegraphs, practically no chance whatever. ${ }^{21}$ Thus even the last hope, the revolutionary hope, is laid at rest.

driven into exile, a commotion which for more or less time incapacitates persons even of superior ability. They cannot keep pace with the march of events and do not wish to realize that the character of the social movement has changed. Hence that play in conspiracy and revolution which compromise both their instigators and the cause which they would serve." Marx, Nachwort zu den Enthïllungen über den Kommunisten-Prozess zu Köln (Hottingen-Zurich, 1885), p. 72. Marx wrote the above sentences apropos of Willich, but the statement is true of Marx himself.

s1 "History proved us wrong, and showed the views which we then held to be illusions. More than that, it not only destroyed our error of that time, but it also completely changed the conditions under which the proletariat was to struggle." EnGers, Einleitung zu Karl Marx's Die Klassenkämpfe in Frankreich, 1848-1850 (Berlin, 1895), p. 6. "The irony of history turns everything upside down. We the 'revolutionaries' thrive much better by legal means than by illegal ones and through 'revolution.'" Ibid., p. 17. 


\section{CHAPTER XII}

\section{THE COLLAPSE OF MARX'S THEORY OF VALUE}

In the first part of the present study it was pointed out that, whatever rôle Marx's theory of value may have played in his economic system, his socialism was not based upon that theory but rather upon the inevitable development of economic tendencies. Accordingly, as long as the relation of Marx to socialism was the primary object of our inquiry, to discuss at the outset his theory of value would have been to confuse the issue. Having disposed of the economic tendencies that were to lead to socialism, we can now consider what socialism stands to gain from this particular theory.

In a sense, any such consideration is rather superfluous. There are few theories that have been so carefully examined, so thoroughly sifted, and so completely condemned upon their own documentary evidence as Marx's theory of value. And since the appearance of the third volume of Capital we have in our hands what may be called a signed confession of Marx and Engels to the effect that this theory is a futile construction. 
What was this famous theory of value? The socially necessary amount of labor-time incorporated in the production of a commodity, we were told, is what constitutes its value. But if, for example, an Indian builds a canoe and exchanges it for a dog that never fails on a deer hunt, would Marx's law of value govern the exchange of the dog for the canoe? Not at all. Marx is investigating capitalist production, the production of commodities for the market, and the economic laws peculiar to that mode of production -peculiar, that is, to modern times. From the very start it was a distinctive feature of Marx's economic theory-a feature not shared by him with his classical predecessors-that universal abstract economic laws do not exist; rather does every historical period have laws of its own. ${ }^{1}$ Historically, therefore, the operative power of Marx's law of value was limited to the

${ }^{2}$ Marx, Capital, vol. i (English translation, I89r), p. xxviii. Cf: DrenL, Sozialwissenschaftliche Erläuterungen zu David Ricardos Grundsätzen der Volkswirtschaft, p. 97: "In contradistinction to Ricardo, Marx brought forward his law of value only for a definite phase of economic life, or to express it differently, for Marx the law of value had only a historic meaning. while for Ricardo it had a general one. Wherever men worked, Ricardo believed, they also bartered for the value of their work. Therefore the law of value was for Ricardo a general permanent law for all kinds and periods of economic life. Marx thought quite differently; he acknowledged no universal law of economics, but only laws applying to definite conditions of production. The law of value was only to hold for the period of production of commodities, and so had no validity for objects of personal consumption, as Ricardo thought, but only for the commodities." 
modern period of capitalist production. It did not apply to wares that were subject to accidental exchange, but only to wares produced by hired labor for sale in the market. This historical limitation imposed by Marx upon his law of value the reader should bear in mind.

What proof does Marx offer that the labor-time congealed in the commodity is what constitutes its value? This very concrete law of value, which is historically circumscribed and limited, is not proven to us by equally limited and circumscribed concrete historical observations, but by abstract reasoning sub specie aternitatis. We may say that literally Marx is rushing in where Aristotle feared to tread. Aristotle wondered considerably about exchange. He reasoned: 5 beds $=$ so much money is the same as 5 beds $=\mathrm{r}$ house. Hence the value of every commodity can be expressed in terms of some other commodity taken at random. But " exchange cannot take place without equality, and equality not without commensurability." Aristotle wondered how things so obviously different as commodities may be can be commensurable. He decided that they cannot be qualitatively commensurable. Hence the equalization that exchange may establish is but "a makeshift for practical purposes." 2

The logical problem thus abandoned by the master himself, Marx undertook to solve twenty-odd hundred 'Capital, vol. i, p. 28. 
years later in the spirit of the Aristotelian scholastic. ${ }^{3}$ He begins with a random equation: one quarter of corn $=x$ hundredweight of iron. "What does this equation tell us? It tells us that in two different things -in I quarter of corn and in $x$ cwt. of iron-there exists in equal quantities something common to both. The two things must therefore be equal to a third, which in itself is neither the one nor the other. Each of them, so far as it is exchange value, must therefore be reduced to this third." 4

This reasoning is interesting. Having thus convinced himself that every exchange equation of two commodities is in reality a sublimated ménage à trois, Marx argues as follows: "This common something cannot be either a geometrical, a chemical, or any other natural property of commodities. Such properties claim our attention only in so far as they affect the utility of those commodities, make them usevalues. But the exchange of a commodity is evidently an act characterized by a total abstraction from its use-

- I do not wish to be understood as speaking lightly of either Aristotle or the master-minds of the scholastic. I readily grant that no one in modern times has equaled them in logic. But the reason why they became such artists in the use of the syllogism was because it was the sole instrument at their disposal. The chaos of facts and the order of tabulated experience was not theirs to deal with. Hence theirs were complete and perfect natural philosophies, while to us was given a natural science in all its incompleteness and imperfection. Our several economic theories, alas, are still quite logical, quite complete and quite perfect.

- Capital, vol. i, pp. 3, 4. 
value. As use-values, commodities are, above all, of different qualities, but as exchange values they are merely different quantities, and consequently do not contain an atom of use-value. If then we leave out of consideration the use-value of commodities, they have only one common property left, that of being products of labor. . . . There is nothing left but what is common to them all; all are reduced to one and the same sort of labor, human labor in the abstract. Let us now consider the residue of each of these products; it consists of the same unsubstantial reality in each, a mere congelation of homogeneous human labor, of labor-power expended without regard to the mode of its expenditure. All that these things now tell us is that human labor is embodied in them. When looked at as crystals of this social substance, common to them all, they are values." 5

Thus we see that Marx is dealing with economic phenomena as a mediæval scholastic, and as such he is not only solving the economic problem of value but is also answering the metaphysical query after the substance of all things. Our nineteenth-century materialist in the garb of a thirteenth-century schoolman shows us in a dim metaphysical light the true noumenon of all phenomena.

A critique of this method of reasoning would have been called for had Marx offered us a theory of value as a mental construction, a Hülfsbegriff; but he is pre-

'Ibid., vol. i, pp. 4, 5. 
senting us not with a theory of value. but with a law of value, a law governing the exchange of commodities. Owing to the concrete nature of this law, it is a simple matter to test its validity. The question is : Is or is not this law of value operative in actual practice?

Marx informs us that the price is but the money expression of value. "The expression of the value of a commodity in gold," he tells us, "is its money-form or price." "The law of value that governs these prices Marx compares with the law of gravity. "In the midst of all the accidental and ever-fluctuating exchange relations between the products, the labor-time socially necessary for their production forcibly asserts itself like an overriding law of nature. The law of gravity thus asserts itself when a house falls about our ears." ? It is important to notice that this statement is reiterated in the third volume. "Whatever may be the way in which the prices of the various commodities are first fixed or mutually regulated, the law of value always dominates their movements. If the labor-time required for the production of these commodities is reduced, prices fall; if it is increased, prices rise, other circumstances remaining the same." 8 The law of value always determines the prices. ${ }^{\circ}$ In fact, to use Marx's own expression, " a price which is different in quality from value is an absurd contra-

- Ibid., vol. i, p. 66.

'Ibid., vol. i, p. 46.
-Ibid., vol. iii, p. 208.

-Ibid., vol. iii, p. 244. 
diction." "10 "The concept of price really signifies the value of some use-value expressed in money." 11 These and similar plain assertions make the problem of testing the Marxian theory of value relatively simple. But before we inquire whether his law stands the test, let us proceed to the second and perhaps more original part of the theory.

The capitalist, the owner of money, must buy commodities at their value, and then he must sell them at their value, yet at the end of the process he must draw out more money than he put in. How is this problem to be solved? How is profit made? This question is answered as follows: there is one commodity, labor-power, which is purchased on the market like all other commodities at its value, but the capitalist extracts from it surplus value.

In order that labor-power may be freely offered on the market, the owner of this commodity, the laboring man, must be a free man, who may dispose at will of his labor-power, i.e., his person. The second historical condition for the existence of labor-power as a commodity is the existence of a proletariat class, that is of people that possess labor-power, but none of the means and instruments of production; or, as Marx puts it: "The second essential condition to the owner finding labor-power on the market as a commodity is this-that the laborer, instead of being in the position to sell commodities in which his labor is incorporated,

"Ibid., vol. iii, p. 417 .

${ }^{12}$ Ibid., vol. iii, p. 417. 
must be obliged to offer for sale as a commodity that very labor-power which exists only in his living self." 12

Now if the capitalist pays on the market the value of labor-power, what is the value of this curious commodity, and how is it to be determined? Marx answers as follows: "The value of labor-power is determined as in the case of every other commodity by the labor-time necessary for production of this special article. Labor-power exists only as a capacity or power of the living individual. . . . For his maintenance he requires a given quantity of the means of subsistence. Therefore the labor-time requisite for the production of labor-power reduces itself to that necessary for the production of those means of subsistence; in other words, the value of labor-power is the value of the means of subsistence necessary for the maintenance of the laborer." ${ }^{13}$

Parenthetically, the reader is urged to keep in mind that Marx is here presenting us with a cost-of-subsistence theory of wages.

The value of labor-power thus resolves itself into the value of a definite quantity of means of subsistence. It therefore varies with the value of these means or with the quantity of labor requisite for their production. ${ }^{14}$ Let us assume that the value of labor-power, thus determined, is three shillings a day, which three shillings the capitalist pays his laborer

12 Ibid., vol. i, p. 147 . ${ }^{13}$ Ibid., vol. i, p. 149.

"Ibid., vol. i, p. 15 I. 
for his labor-power. But, argues Marx, if the capitalist should make the laborer work only as many working hours as are necessary to the production of the labor-power he has purchased-let us say four or five or six hours-no surplus would arise. The four or six hours of work, as the case may be, would not contribute to the finished product of the laborer a value greater than that of the three shillings which the capitalist has paid in wages. No profitable business could be carried on in this way; hence, according to Marx, while the capitalist pays to the laborer the three shillings, which is equivalent, let us say, to six hours of labor, he makes the laborer work the whole day-let us say, twelve hours. Thus the laborer produces not only the three shillings which he has received in wages, but an additional three or more shillings, which is surplus value for the capitalist.

From the viewpoint of the capitalist, however, the surplus value thus produced by the laborer is by no means clear profit for the employer.

Production requires capital. Capital engaged in production Marx divides into constant and variable capital. Constant capital is that part of the capital that is invested in the means of production-building machinery, material, etc.-which produces as such no surplus value. Variable capital is capital invested in the purchase of labor-power, in hiring workmen. Only this portion of capital is productive of surplus value.

If a certain productive enterprise requires $\mathfrak{k}_{4}$ Io of 
COLLAPSE OF THEORY OF VALUE 263

constant capital and $£_{90}$ of variable capital, and the rate of surplus value on the variable capital is 100 per cent or $£_{90}$, the capitalist is receiving $\mathfrak{f}_{90}$ of surplus value on a total investment of $\mathfrak{f}_{4} 10+\mathfrak{f}_{90}=$ $£ 500$, or 18 per cent. If, on the other hand, the branch of industry is one in which the value of the implements and material used is slight, if the constant capital used is but $\mathfrak{E}_{10}$ and the variable capital $\mathfrak{£}_{90}$, and if the surplus value is again $£_{90}$, then the rate of surplus value is the same, 100 per cent, but the rate of profit to the capitalist on his whole investment of $£_{100}$ is 90 per cent.

It is therefore evident that in various industries, in which the rate of surplus value is the same, the rate of profit will vary in accordance with the composition of the capital concerned, in accordance with the ratio of constant capital to the variable capital employed. The higher the ratio of variable capital, the higher will be the rate of profit; and, vice versa, the higher the ratio of constant capital, the lower will be the rate of profit. In industries which require little or no machinery and raw material of slight value, together with a great deal of human labor-power, the rate of profit will be very high. On the other hand, the larger the investment in machinery and material, the slighter the proportion of labor-power used, the smaller will be the profit; since it is only from living human labor that surplus, value can be derived.

If the Marxian theory is true, industries resting 
primarily on human labor must produce a proportionately higher rate of profit than enterprises in which the ratio of constant capital is high. Yet Marx himself admits that experience shows the rate of profit in the various industries to be entirely independent of the inner composition of capital employed in these various industries. A railroad which represents an enormous investment of constant capital and a relatively slight proportion of variable capital may give the same rate of profit as a district messenger company or any other enterprise in which the largest amount of capital is spent on wages. In fact there is a general tendency to an average rate of profit. This tendency is admitted by Marx. But if an average rate of profit be admitted, how can it be claimed that the Marxian law of value is to operate like the law of gravity? On the face of it this admission seems to invalidate the whole theory of value.

This was the puzzle that Marx promised to solve. Attention was drawn to the difficulty by Engels himself, in 1885 , in the preface to the second volume of Capital, in which he challenged the economists to solve the problem how " an equal average rate of profit can and must come about, not only without a violation of the law of value, but by means of it." ${ }^{15}$ That was

15 "According to the Ricardian law two investments making use of the same amount of labor, and paying it at the same rate, all other conditions being equal, will produce in equal periods of time products of equal value, and likewise an equal surplus value on an equal rate of profit. If, however, they 
the Chinese puzzle, the solution of which was advertised to appear in the third volume of Capital.

The third volume finally appeared. It is a most important document, because it forever disposed of the famous exploitation theory of value. It is a signed admission that the theory is worthless. Not only is Marx compelled to abandoh it, but the way in which he does it is forced and graceless; he shifts his ground and abandons in all haste not only his theory of value, which is untenable, but also his historical method, which would have ensured even to his failure the renown of a great attempt. Professor Loria asked, after reading this third volume of Capital, if there ever was a more complete reductio ad absurdum, a greater theoretical bankruptcy, or if a scientific suicide was ever committed with greater pomp and solemnity.

Marx's law of value of the capitalist mode of pro-

make use of unequal amounts of labor, they cannot produce equal amounts of surplus value or of profit, as a Ricardian would call it. The opposite, however, is the case. As a matter of fact, equal investments produce, regardless of how much or how little wage labor they employ, equal average profits in equal periods of time. Herein lies, therefore, a contradiction to the law of value which Ricardo himself discovered, and which his school was unable to explain. . . The economists who are anxious to discover in Rodbertus the secret source and a philosophical forerunner of Marx have here an opportunity to show what Rodbertian philosophy can accomplish. If they prove how an equal average rate of profit can and must come about, not only without a violation of the law of value, but by means of it, then we can hold further converse with each other." MARX, Kapital, vol. ii (Hamburg, 1893), p. xxii. 
duction, which in the first volume was presented as a natural law, like the law of gravity, is nullified in the third volume by capitalist competition. The capitalist does not care for the organic composition of his capital investment. It is immaterial to him whether he has invested $\mathfrak{f}_{90}$ in constant capital and $\mathfrak{f}_{10}$ in variable capital, or whether his capital investment is composed of $\mathfrak{f}_{\text {ro }}$ constant $+\mathfrak{f}_{90}$ variable capital. In either case he has invested $\mathfrak{E}$ roo, and upon the sum total of his investment he expects a return. Different as the organic compositions of the various capital investments may be, "a difference in the average rate of profit in the various lines of industry does not exist in reality, and could not exist without abolishing the entire system of capitalist production." ${ }^{16}$ Apparently, then, the theory of value is irreconcilable at this point with the actual process, irreconcilable with the real phenomena of production, so that we must give up the attempt to understand these phenomena. In the first part of this volume it is admitted that the cost prices are the same for products of different spheres of production, in which equal portions of capital have been invested for purposes of production, regardless of the variable composition of such capitals.

${ }^{16}$ It was with a theoretical analysis of capitalist production alone that Marx dealt in his Capital, and the "laws" he promulgated were to be laws of capitalist production. Cf. Capital, vol. $i$, pp. xxviii, 146,147 . It should be noted that the subtitle of the authorized English translation of the book is "A critical analysis of capitalist production." 
The cost price does not show any distinction between variable and constant capital as regards the return to the capitalist. A commodity for which he must advance $£ 100$ in production costs him the same amount, whether he invests $£_{90} \mathrm{c} .+£_{10} \mathrm{v} .$, or $£_{10} \mathrm{c} .+£_{90} \mathrm{v}$. He always spends $E_{100}$ for it, no more, no less. The cost prices are the same for investments of the same amounts of capital in different spheres, no matter how much the produced values and surplus values may differ. The equality of cost prices is the basis for the competition of the invested capitals, by which an average rate of profit is brought about. ${ }^{17}$

This is a formal retreat to the classical cost-ofproduction theory of value. The statement that the price is but the money expression of value and the assertion that commodities exchange according to their values are simply dropped. Instead, we are told that in reality the average rate of profit on the entire cost of production is maintained, regardless of the so-called organic composition of capital. In reality, therefore, the commodities are sold either above or below their value.

Some economists, after hearing of the final solution of Marx's value problem, called the whole Marxian construction a mystification. After the much-heralded new natural law-his own law of value-we are told in the third volume that,the price has nothing to do with value. "The price of production of a commodity, ${ }^{17}$ Capital, vol. iii, pp. 181, 182. 
then, is equal to its cost price plus a percentage of profit apportioned according to the average rate of profit, or, in other words, equal to its cost-price plus the average profit." 18

If the value of the product does not regulate the price of the product, if the profit of the capitalist is not determined by the surplus value extracted by him but by the average rate of profit that he gets on the sum total of the cost of production, then the first volume of Capital might as well never have been written. The reader might have been spared all the nearAristotelian metaphysical chase after the tertium comparationis, that is defined as neither one thing nor another, but as an unsubstance, as a jelly (Gallerte) of human labor, and as ruling all exchange and establishing all equations under the name of value. Marx affirmed that his law of value was a working law; it did not prove to be so, and he admitted it; but the blame he put not upon the law he had discovered, but upon the perversity of mankind, who act without any understanding for the innermost meaning of things as revealed by Marx. "If it is realized-and the reader will have realized it to his great dismaythat the analysis of the actual internal interconnections of the capitalist process of production is a very complicated matter and a very protracted work; if it is a work of science to resolve the visible and external movement into the internal actual movements, then it ${ }^{18}$ Ibid., vol. iii, p. 186. 
is understood, as a matter of course, that the conceptions formed about the laws of production and circulation will differ widely from these real laws and will be merely the conscious expression of the apparent movements. The conceptions of a merchant, a stockgambler, a banker, are necessarily quite perverted. Those of the manufacturer are vitiated by the acts of circulation, to which their capital is subject, and by the compensation of the general rate of profit." 19

How then, one would ask, does Marx reconcile his law of value with the above admissions?

He tells us that if we take the sum of all capital investments in their aggregate as one product, then the product in its aggregate, and only in its aggregate, will sell exactly at its value. But the products of a single capitalistic enterprise do not sell at their values. Why not? Because, says Marx,- " if the commodities are sold at their value, then, as we have shown, considerably different rates of profit arise in the various spheres of production, according to the different organic composition of the masses of capital invested in them. But capital withdraws from spheres with low rate of profit and invades others which yield a higher rate. By means of this incessant emigration and immigration, in one word, by its distribution among the various spheres in accord with a rise of the rate profit here, and its fall there, it brings about such a proportion of supply to demand that the average 10 Ibid., vol. iii, p. 369. 
profit in the various spheres of production becomes the same, so that values are converted into prices of production. ${ }^{20}$

Does the reader realize what Marx has proved by this statement? Squarely and clearly and forcibly Marx states here, and proves it to us, that commodities exchange not in proportion to the labor they contain. In other words, the theory of value as originally formulated by Marx is false. But, we are told, the sum of the prices of all production is equal to the sum of their values. This statement has no meaning whatsoever, because the sole raison d'être of a theory of value is to explain to us the relations and proportions of exchange. The idea that the totality of all production is equal to the sum total of all products is not exactly adapted to revolutionize the thinking world. Let me quote Böhm-Bawerk's reply to this statement of Marx:

"There can clearly only be a question of an exchange relation between different separate commodities among each other. As soon, however, as one looks at all commodities as a whole and sums up the prices, one must studiously and of necessity avoid looking at the relations existing inside of this whole. The internal relative differences of price do compensate each other in the sum total. For instance, what the tea is worth more than the iron, the iron is worth less than tea and vice versa. In any case, when we ask for ${ }^{20}$ Ibid., vol. iii, pp. 230, 231. 
information regarding the exchange of commodities in political economy, it is no answer to our question to be told the total price which they fetch when taken all together, any more than if, on asking by how many fewer minutes the winner in a prize race had covered the course than his competitor, we were to be told that all the competitors together had taken twenty-five minutes and thirteen seconds.

"The state of the case is this: To the question of the problem of value the followers of Marx reply first with their law of value, i.e., that commodities exchange in proportion to the working time incorporated in them. Then they-covertly or openly-revoke this answer in its relation to the domain of the exchange of separate commodities, the one domain in which the problem has any meaning, and maintain it in full force only for the whole aggregate national produce, for a domain therefore in which the problem, being without object, could not have been put at all. As an answer to the strict question of the problem of value, the law of value is avowedly contradicted by the facts, and in the only application in which it is not contradicted by them it is no longer an answer to the question which demanded a solution, but could at best only be an answer to some other question.

"It 'is, however, not even an answer to another question; it is no answer at all; it is simple tautology. For, as every economist knows, commodities do eventually exchange with commodities-when one pene- 
trates the disguises due to the use of money. Every commodity which comes into exchange is at one and the same time a commodity and the price of what is given in exchange for it. The aggregate of commodities, therefore, is identical with the aggregate of the prices paid for them; or, the price of the whole national produce is nothing else than the national produce itself. Under these circumstances, therefore, it is quite true that the total price paid for the entire national produce coincides exactly with the total amount of value or labor incorporated in it. But this tautological declaration denotes no increase of true knowledge, neither does it serve as a special test of the correctness of the alleged law that commodities exchange in proportion to the labor embodied in them. For in this manner one might as well, or rather as unjustly, verify any other law one pleased-the law, for instance, that commodities exchange according to the measure of their specific gravity. For if certainly as a "separate ware" I lb. of gold does not exchange with I lb. of iron, but with 40,000 lbs. of iron; still, the total price paid for I $1 \mathrm{~b}$. of gold and 40,000 lbs. of iron taken together is nothing more and nothing less than $40,000 \mathrm{lbs}$. of iron and I lb. of gold. The total weight, therefore, of the total price-40,00r lbs. -corresponds exactly to the like total weight of 40,00I lbs. incorporated in the whole of the commodities. Is weight consequently the true standard 
by which the exchange relation of commodities is determined?" 21

How fundamentally untenable Marx's theory is, is shown by Engels's desire to shift the historical setting of the whole proposition. Such an attempt is already suggested by Marx himself in his third volume of Capital. ${ }^{22}$ Engels takes up Marx's suggestion and informs us that Marx's law of value was generally valid economically from the beginning of all recorded history down to the fifteenth century. ${ }^{23}$ For thousands of years commodities exchanged in the ratio of the labor value they contained, even if they do not exchange so now. This period extended, according to Engels, anywhere from five to seven thousand years, but ended some five centuries ago! This explanation is pathetic. Marx definitely and crisply informed us that his law was valid only for the capitalist mode of production, for the period of the manu-

21 BöHM-BAWERK, Karl Marx and the Close of His System (New York, 1898), pp. 72-75.

${ }^{32}$ Capital, vol. iii, p. I56.

2z "Marx's law of value was therefore generally valid economically from the beginning of the period that through exchange turned products into commodities down to the fifteenth century of our era. The exchange of commodities, however, dates from a time anterior to all written records, stretching back in Egypt to a period at least 2,500 and perhaps 5,000 years, and in Babylon 4,000 and perhaps 6,000 years B.c.: the law of value has therefore been in force for a period of from 5,000 to 7,000 years." Fr. ENGELS, Letzte Arbeit: Ergänzung und Nachtrag zum dritten Buch des "Kapital": Die Neue Zeit, Jahrg. XIV, I896, vol. i, p. 39. 
facture of commodities for the highly developed market, where exchange is not accidental and is impersonal. $^{24}$ Furthermore this period was limited to those times in which there has been a free proletariat class-free as to their persons, equal to their employer before the law, but having for sale no other commodity but their labor-power. Or, as Marx puts it,-_ "Labor-power can appear upon the market as a commodity only if, and so far as, its possessor, the individual, whose labor-power it is, offers it for sale, or sells it, as a commodity. In order that he may be able to do this, he must have at his disposal, must be the untrammeled owner of, his capacity for labor, i.e., of his person. He and the owner of money meet in the market and deal with each other on the basis of equal rights, with this difference alone, the one is buyer, the other is seller; both therefore equal in the eyes of the law." ${ }^{25}$ Marx's entire theory is thus an analysis of capitalist production; and now, when the collapse of his law of value is too obvious to be discussed, we are told that if the law is not true for capitalist production it was nevertheless true for the period preceding the fifteenth century, i.e., for the periods of domestic economy, of barbarism, of slavery, of serfdom-in short, for any period except the one where, in Marx's scheme, it would have had some meaning and importance.

\footnotetext{
${ }^{24}$ Capital, vol. iii, p. 209. Cf. supra, p. 255.

${ }^{25}$ Ibid., vol. i, p. 146; item.
} 
At first glance it may look as if Marx faced the débâcle only when he tried to solve the problem of the average rate of profit in his third volume of Capital. A close examination will show, however, that he was quite aware of the situation while writing his first volume. The collapse of his law of value is already there. Only look at his theory of wages. Marx tells us that labor-power is a commodity and its value is determined like that of any other commodity: "The value of labor-power is determined, as in the case of every other commodity, by the labor-time necessary for the production, and consequently also the reproduction, of this special article. So far as it has value, it represents no more than a definite quantity of the average labor of society incorporated in it. Labor-power exists only as a capacity, or power of the living individual. Its production consequently presupposes his existence. Given the individual, the production of labor-power consists in his reproduction of himself or his maintenance. For his maintenance he requires a given quantity of the means of subsistence. Therefore the labor-time requisite for the production of labor-power reduces itself to that necessary for the production of those means of subsistence; in other words, the value of labor-power is the value of the means of subsistence necessary for the maintenance of the laborer." ${ }^{28}$ This is a clear-cut statement of the cost-nf-subsistence theory of wages and is quite in ac-

$$
\text { "' Ibid., vol. i, p. } 149 .
$$


cord with Marx's value theory. But is this the theory of wages that Marx maintains? Not at all. He declares himself a strenuous opponent of the iron law of wages, as we have pointed out in a preceding section of the present study. ${ }^{27}$ The cost-of-maintenance theory is quite abandoned in his final reserve-army and increasing-misery theory of wages. At times the price of labor-power is much above the cost of maintenance, only too often much below that cost, but " in proportion as capital accumulates, the lot of the laborer, be his payment high or low, must grow worse." ${ }^{28}$ Under no circumstances does Marx's law of value regulate the price of the commodity of labor-power. It is regulated, according to time, by the competition of the reserve army of the unemployed with those employed. And this reserve army of unemployed, this relative surplus population, is created by machinery, the "labor-saving" device invariably called in by capital as soon as the margin of surplus value pressed out by the capitalist becomes narrow. ${ }^{29}$

So here again prices are regulated not by the law of value but quite independently of that law. Thus we

${ }^{27}$ See note on pp. 99-100 and pp. III-II9.

${ }^{28}$ Capital, vol. i, p. 66r.

${ }^{20}$ For additional substantiation of the conflict between Marx's law of value and his theory of wages, $c f$. the extremely just and learned study of DienL, "Ueber das Verhältnis von Wert und Preis im ökonomischen System von Karl Marx," in the Festschrift zur Feier des 25-jährigen Bestehens des staatswissenschaftlichen Seminars in Halle (Jena, 1898), especially chapter iv: "Wert und Preis der Arbeitskraft." 


\section{COLLAPSE OF THEORY OF VALUE 277}

see that the so-called great central doctrine-the law of value-is but a bubble, admittedly without any validity in concrete economic experience and even without continuous cohesion as a mental construction. If the reader so chooses, he may disregard all hostile criticisms of the theory. All he has to do is to follow Marx, and he will arrive at the complete destruction of Marx's own central doctrine. 


\section{CHAPTER XIII}

\section{MARX'S ATTITUDE TOWARDS ETERNAL JUSTICE. CONCLUDING REMARKS}

MARx's theory of value came to grief. ${ }^{1}$ But let us assume for argument's sake that this law of value is as valid as the law of gravitation. What does socialism stand to gain from such an assumption? If the law of value is true, then all accumulated capital is

${ }^{1}$ Marx, as a mere youngster, in discussing Szeliga's mysteries of speculative construction, ridiculed in advance the logical construction of his own future theory of value. He had not then written about an unsubstantial reality of things or about commodities as a jelly of abstract human labor, but he might almost have been discussing the mysteries of his own theory of surplus value when he wrote: "If from real apples, pears, strawberries, almonds, I form the general idea 'fruit,' and if I go further and imagine that my abstract idea, derived from the concrete fruit, has an existence outside of myself, is, indeed, the real existence of the pear, apple, etc., then I postulate the speculative 'fruit' as the 'substance' of the pear, the apple, the almond, etc. I state, therefore, that it is non-essential for the pear to be a pear or the apple to be an apple. What is essential to these objects is not their real existence which is evident to the senses, but the generalization that I have made of them, the essence of my own conception 'fruit,' by which name I called their substance. I then proclaim that the apple, the pear, the almond, etc., are merely states or 'modi' of the 'fruit.' . . ." FrIEdRICH ENgels and KARL MARX, Die heilige Familie oder Kritik der kritischen Kritik: Gegen Bruno Bauer und Consorten (Frankfurt a. M., I845), p. 79; reprinted in Literarischer Nachlass, vol. ii, p. 156. 
an accumulation of unpaid labor, then ail profit is but realized exploitation, then the character and meaning of wage slavery is fully explained. Then the injustice of the capitalist mode of production is so palpable and so appalling that the abolition of private ownership of means of production is a moral necessity. This is precisely what is being said now by so many socialists. This is precisely what has been said in the past; and it is precisely this attitude of mind that led Marx to differentiate himself from his socialist forerunners and to preach a system of his own. The most original and most lasting contribution of his was his conception of economic necessity. "Justice, Humanity, Liberty, etc., may have called a thousand times for this or for that, but if it is impossible, it will never be realized and will remain but an empty dream." 2 For empty dreams he had little respect; and as such dreams he regarded all humanitarian and utopian socialism and all social reform. "These gentlemen," he said, "hate thinking, heartless thinking, as they hate struggle and development. As if any thinker, Hegel and Ricardo not excluded, had ever been so heartless as to slop over our heads such soft-mouthed slobber." ${ }^{3}$ The reader can find many such sentiments expressed by Marx about his idealistic contemporaries.

2 Literarischer Nachlass, vol. iii, p. 249.

I Ibid., vol. iii, p. 476 .

- See for instance what he had to say about the early New York socialist, Hermann Kriege. Literarischer Nachlass, vol. ii, pp. $415,416$. 
Even real slavery Marx regarded as a necessity, under given economic conditions. $\mathrm{He}$ was by no means an abolitionist. So he wrote in 1847 : "Without slavery you have no cotton, without cotton you cannot have modern industry. It is slavery which has given their value to the colonies, it is the colonies which have created the commerce of the world, it is the commerce of the world which is the essential condition of great industry." "Several years later we find him repeating the same argument, and also explaining under what conditions he expected the disappearance of slavery.

" This fact, however, goes straight back to the only possible and practical solution of the slave question, that again has caused so many long debates in Congress. Cotton production in America rests upon slavery. As soon as the industry has reached such a development that it refuses to put up with the American monopoly of cotton, just so soon will the production of cotton in large quantities be a success in other lands, and practically everywhere at the present time this can be done only through free labor. But as soon as free labor in other lands produces cotton as extensively and as cheaply as slave labor in the United States, the American monopoly of cotton and American slavery will together be broken, and the slaves will be emancipated because they have become useless as slaves. Similarly will wage labor in Europe be

- The Poverty of Philosophy (1900), p. 90. 
done away with as soon as it has become not only an unnecessary part of production but even a fetter upon it." 6

We are dependent upon our industry, Marx explained, and we are not in a position to dictate humanitarian conditions upon which production is to rest. As a revolutionary socialist he argued at times like Nassau Senior. He was, as a matter of fact, against the ten-hour bill, because he feared that the famous factory act might cripple British industry. So we read: "The whole social development of England is part and parcel of the development and progress of industry. All institutions that stop this progress, or limit it, or regulate it according to external plans, are reactionary, impossible, and have to succumb. The revolutionary forces that so easily had their way with the whole patriarchal society of England, with the landed aristocracy, and with the financial aristocracy, will surely not let themselves be hemmed within the limits of the ten-hour bill." ?

Marx in course of time changed his hostile attitude toward the factory acts and toward labor legislation in general, as his inaugural address before the International in 1864 plainly indicates; but his attitude towards the "demand for justice" remained the same. When, in 1875 , the German social democracy adopted a program in which it based its demands upon " just

- Literarischer Nachlass, vol. iii, pp. 458, 459.

'Ibid., vol. iii, p. 392. 
distribution," Marx criticised that program bitterly and asked in derision: What is "just distribution"? Does not the bourgeoisie regard the present mode of distribution as "just"? And is it not, as a matter of fact, the only " just" distribution on the basis of the existing mode of production? Does not every socialist sect have different conceptions as to what may constitute a "just" distribution? The law governing distribution is dependent upon its economic basis and cannot be of a higher type than the economic development of society may justify. ${ }^{8}$ For the so-called ideas of eternal justice Marx had a distinct aversion, for two obvious reasons. First of all, these ideas were but touched-up and beautified reflections of very temporary conditions. So he wrote about the utopian schemes of the English socialist Bray: "Mr. Bray does not see that this equalitarian relation, this corrective ideal, which he wishes to apply to the world, is itself nothing but the reflection of the existing world, and that it is in consequence quite impossible to reconstitute society on a basis which is only an embellished shadow. In proportion as this shadow becomes substance, it is seen that this substance, far from being the dreamed-of transfiguration, is nothing but the body of existing society." " The other objection of Marx to the appeal to justice as a means of reconstructing society, is that this appeal, while interesting and symp-

- Die Neue Zeit, I890, vol. i, pp. 565, 566.

- The Poverty of Philosophy, p. 53. 
tomatic, is as a whole utterly futile. Have we not heard that appeal, asked Marx, for eighteen hundred years, and what is the net result? ${ }^{10}$

A clever advocate of orthodox Marxism, Dr. Luxemburg, calls the principle of justice the good old Rosinante, upon which every Don Quixote of the world's history has taken a ride, to return home finally with nothing but a black eye to show for his trouble. ${ }^{11}$

This attitude of Marx and Engels is expressed in unmistakable language in every important work of theirs, in their earlier as in their later writings. Engels emphasizes it clearly in his Anti-Duehring. "If we have no better security for the revolution in the present methods of distribution of the products of labor, with all their crying antagonisms of misery and luxury, of poverty and ostentation, than the consciousness that this method of distribution is unjust and that justice must finally prevail, we should be in evil plight and would have to stay there a long time. The mystics of the Middle Ages, who dreamed of an approaching thousand-years kingdom of righteousness, had the consciousness of the injustice of class antagonisms. At the beginning of modern history three hundred

10 Literarischer Nachlass, vol. ii, p. 416.

11 "Then we fortunately arrived at the principle of justice, at that old horse ridden for many thousands of years by all world-reformers in default of surer historical means of locomotion, at the clattering Rosinante, on which all the Don Quixotes of history have ridden forth to reform the world, only to return home finally with nothing to show but a black eye." LuxEmBURG, Sozialreform oder Revolution (1899), p. 45. 
years ago, Thomas Muenzer shouted it aloud to all the world. In the English and French bourgeois revolutions, the same cry was heard and died ineffectually. ${ }^{12}$. . . This appeal to morality and justice does not bring us a step further scientifically. Economic science can find no grounds of proof in moral indignation, however justifiable, but merely a symptom. . . The feeling stirred up by the poets, whether in picturing these social wrongs or by attack upon them or, on the other hand, by denial of them and the glorification of harmony in the interests of the dominant class, is quite timely, but its slight value of furnishing proof for a given period is shown by the fact that one finds an abundance of it in every epoch." 13

I might go on quoting ad infinitum from Marx and from Engels, but their point of view is quite clear. And how could Marx's attitude towards the "appeal to justice" be different? His fundamental proposition was that all legal and political institutions, all ideologies, all our ideas of justice, etc., are dependent on the economic basis. Development of economic conditions, shifting of the economic basis, will affect and change prevailing ideas of law and justice. It is the economic conditions, the forces of production, that drive society and influence individuals; our ideas of good and evil are but products of these basic forces.

12 Engels, Landmarks of Scientific Socialism (Anti-Duehring), pp. 182, 183. Cf. also pp. 123, 127, 128, 131.

${ }^{13}$ Ibid., p. 180. 
How then could Marx turn about and expect that these ideologies, which are subject to constant change, should influence, much less reconstruct, the basic economic conditions? Marx could not assume the sovereign rule of forces of production, he could not assume that our future is definitely revealed to us by economic tendencies, and yet grant that these economic tendencies are mere clay to be modeled by an ideological conception of our own.

"Eternal" justice was to Marx an object of derision. The ideas of justice are constantly changing, changing from time to time, from people to people. Our ideas of social justice are quite different from those of the Roman world, different from those of the feudal world, different even from those of our grandfathers; and those that will be held by our grandchildren are bound to be different from ours. These ideas change with the changes in the economic conditions. Righteous indignation may accompany profound economic changes, but it does not produce or create those changes. That is why Marx expected his socialism and his social revolution to be the result of the development of economic forces-a development indicated and revealed to us by the existing economic tendencies, tendencies that lead to the "expropriation of the expropriators," the social revolution, and the new social order.

In a preceding chapter I tried to point out how much Marx overestimated the significance of his eco- 
nomic interpretation of history. ${ }^{14}$ It has other more fundamental faults. Even granting that all changes in our ideologies are produced by economic changes, the ideologies themselves are by no means explained. Granted that economic conditions influence and affect religious beliefs, the theory does not account for religious beliefs as such. To take a more concrete and simple example: let us grant that economic conditions are responsible for the longer legs of the western-plain horseback Indian and for the shorter legs of the eastern canoe Indian; the existence of legs as such, short or long, is still hardly explained by economic conditions. At best, therefore, only the change of a given thing can be explained by the change of the economic conditions, but not the thing itself. If that is true, who is to tell us how much of the development is due to the inner momentum or life of the thing itself, quite independently of all economic conditions?

The profound influence of economic forces no intelligent man will deny. We are quite prepared to admit that, in so far as forecasts of the future are at all legitimate, such forecasts or rather approximate estimates are possible only upon the basis of economic tendencies, provided, however, the conservative influence of deeply rooted traditions is not overlooked.

We have seen that our economic tendencies do not justify the expectation of a collapse of the capitalist mode of production, nor do they herald the coming ${ }^{14}$ Pp. 33-4r. 
of a socialist commonwealth. This has become quite obvious to all the serious and open-minded socialists of Europe. They were socialists and Marxists; they accepted the propositions of Marx because his keen analytical critique eliminated all previous utopian schemes and all other types of socialism. They accepted Marx's very plausible statement that the economic tendencies he described must lead to socialism. But these tendencies have not persisted. For example, no one in his senses can assume that an increasing number of independent and well-to-do farmers presages the coming of socialism. Such a tendency is making a socialist commonwealth less possible than ever.

We have seen that there was actually not a tendency left to which socialists who were willing to look squarely at facts could pin their faith. More than that, the Marxian doctrine had become a trap for socialism; the clear-headed knew, the many felt, that this doctrine, to use the Marxian phraseology, "from a means of development had turned into a fetter." If it is only through the inevitable economic tendencies that we can be led to socialism, and if such tendencies begin to indicate anything but socialism, then socialism is not to be reached at all.

Is this not precisely what the successor and follower of Marx, Karl Kautsky, himself said? Did he not tell us, in his Erfurter Programm, that so long as a peasant remains a peasant he will adhere, no matter 
how ill he may fare, to private ownership of the means of production? ${ }^{15}$ Did not this same Kautsky, in attacking Bernstein, clearly formulate the situation? In discussing Bernstein's facts and figures in 1898 he made this admission: "If they are true, then not only is the day of our victory postponed, but we can never reach our aim. If capitalists are on the increase and not the propertyless, then development is setting us back further and further from our goal, then capitalism intrenches itself and not socialism, then our hopes will never materialize." 16

Bernstein was quite right in his figures, and Kautsky was quite right in his statement. It meant that the great system of scientific socialism, which Marx had built up with so much learning and acumen, had become an arsenal of arguments against the coming of socialism. Who could deny that Marx's realistic theory was the terrific force which organized, uplifted, unified the socialist movement throughout the world? Precisely this very force had now turned against international revolutionary socialism.

The spokesmen and thinkers of scientific socialism have realized the situation, and for them the last decade or so has been a period of attempts to escape from an untenable position. First of all, attempts were made to interpret Marx, to tone him down, to twist his statements so that they might not contradict

${ }^{15}$ KaUtsky, Erfurter Programm (1892), p. 180.

10 Protokoll der Stuttgarter Parteitags, 1898, p. 128. 
too glaringly the very obvious facts. Nearly all the surviving orthodox Marxists belonged to this category. But theirs was a losing fight. It was a slow retreat before the incoming tide of revisionism.

Revisionists call themselves socialists, they are members of the Socialist party; and, if not to-day, then to-morrow, they will control the theoretical platform of the German Socialist party as completely as they already control its practical policies. Barring Kautsky, nearly every socialist scholar of merit belongs to that wing; barring Bebel, who has often sided with them, nearly every practical leader of note is actually a revisionist, whether or not he accepts the designation. Of socialism they have preserved only the name; they are social reformers. Bernstein, who inaugurated the revisionist movement, frankly admits in his book, Die Voraussetzungen des Socialismus, that the goal of socialism-the socialist commonwealth-means nothing to him, while the social movement means everything.

Bernstein has grave doubts whether the state can ever take over the great industries. In fact, he gives excellent reasons why they can not be taken over by the state $;^{17}$ and he points out how utterly impossible

17 "Can the state take over world industries? What would that mean? Can the modern state take possession of industries whose business is in large part of a speculative nature, - industries which with their products and their possibilities enter the world market as competitors, and in the struggle for sale and commissions develop all the fine qualities of modern com- 
it would be for workingmen to take over what the state cannot possibly handle. Industries expropriated in a revolution would prove to be empty shells, utterly worthless to the revolutionary proletariat.

It is obvious that this is the point of view of a social reformer. It would be a misnomer to call it socialism, were it not for the fact that there is no room left for real socialism in our present-day economic development.

petition? If the state neither will nor can do this, are these industries, which play so great a part in modern economic life, which together employ armies of laborers, and on whose existence the well-being of a great part of the population depends, are they in a social catastrophe to be delivered over to ruin simply because the state cannot take them over? Quite other means and quite different methods must be employed to bring them gradually under stronger control by the state, which can only slowly and by degrees become master of the situation. During a very real revolutionary movement the workingmen in the Russian industrial centers have become only too well aware of it. . . . If I am not mistaken, Kautsky, in the statement which he made here in Holland concerning the beginning of the revolution, developed the idea that the voluntary abandoning of the factories by the manufacturers would be one of the first results of the revolution of the laboring class, and that the manufacturers would say, 'Very well; take the factories away, but leave us alone.' Truly this is very possible, and I admit that such an expropriation would be very cheap. The only question is whether the workingmen shall or can take over the factories, of which the state cannot take charge, and carry them on with success. And after all that we have heretofore seen, we are forced to the conclusion that workmen neither will nor can assume control of the factories. In a revolution the factories thus cheaply expropriated would be mere empty husks." BeRnsteIn, Der Revisionismus in der Socialdemokratie (Amsterdam, 1909), pp. 23-25. 
Interesting is the history of another distinguished Marxist leader, Peter von Struve. He introduced Marxism into Russia and, together with TuganBaranowsky, became one of the chief exponents of Marxism in that country. Struve had to pass through precisely the same development as Bernstein. Their views to-day are very much alike; but while Bernstein is the leader of the "Socialists" in Germany, Struve does not call himself any longer a socialist, but is one of the leaders of the Constitutional Democratic party. In their theory, in their hopes for the future, in their practical policies, these two men are as alike as two peas; but one is called a socialist, the other a Liberal Democrat. Twenty years ago both of them were revolutionary socialists. If we turn to Italy, we find the same situation. The venerable Professor Ferri, who for decades led the Italian socialists as a scholar and a politician, found himself compelled to admit that socialism had lost its meaning; and since he was not willing to call himself a Marxian socialist when he had become a social reformer, he frankly abandoned both socialism and his party.

But there is no necessity to cite luminaries and great leaders. What is true about them, is true about the every-day socialist worker. Mr. Walling, an ardent revolutionary socialist, writes in his recent book: "There can be no doubt that Socialist reformism has become very widespread. . . . It is doubtless true, as Mr. Gompers says, that the individuals 
he questioned have practically abandoned their Socialism, even though they remain members of the Socialist parties." 18

Whether they call themselves revisionists, reformists, laborites or plain socialists, whether they go on respecting the old melodramatic phrases or not, the overwhelming majority of the socialists of to-day are tending to be reformers. Their Marxian training does not permit them to be utopians, and the faith in socialism as an inevitable economic necessity is rapidly evaporating, the economic facts being what they are.

On the other hand, revisionism, which amounts to social reform, to gradual betterment, with hope for the future but without any promises as to the final outcome, has failed to satisfy those who have expected an immediate and final solution of the social problem. Temperamentally irreconcilable to mere social reform, yet admitting the untenability of scientific socialism, they required a different revision of Marx. Men of this fanatical temperament had to become revolutionary revisionists, and this temperamental demand has been supplied in the Latin countries by the so-called "syndicalism."

George Sorel, Ed. Berth, Leone, Labriola, and other syndicalists are very interesting critics of Marx, and I am sorry that I cannot find room for their criticisms in this study. To me, however, syndicalism seems more interesting than important. Acutely disturbing ${ }^{18}$ Walling, Socialism as It Is, p. I21. 
as the movement may be, it is, in my opinion, very ephemeral. In fact, its leaders Sorel and Berth have already abandoned it and exchanged it for -monarchism! When invited to an Italian Syndicalist Congress in December, I9ro, M. Sorel replied that, in his opinion, syndicalism had not realized what was expected from it. Many hoped that the future would correct the evils of the present hour, he said, but he felt himself too old to live in distant hopes; and he had decided to employ the remaining years of his life in the deeper study of other questions which keenly interested the cultivated youth of France. ${ }^{19}$

Now that the socialist parties have become in reality reform parties, they may become even tamer than they are to-day; but why should they give up the old phrases? Talk about the "social revolution" may sound fantastic, in view of the existing economic conditions and tendencies, but it is more than talk. The inevitable cataclysm and the social revolution have a mystical quality, and hence they are assets. A social movement that is quite sensible, quite reasonable, is the wildest of all utopias. Such a movement can no more keep alive without faith, than faith can keep alive without miracles, wrought or prophesied. The social revolution that is to come has all the essential characteristics of the standard miracle: it is to be sudden, and it is to be final. What element of the miraculous would there be in a slow but steady con-

"Levine, The Labor Movement in France, pp. 15I, 152. 
valescence? And how unsatisfactory a miraculous cure would be if it had to be repeated! Social reform cannot arouse the passionate ardor that is kindled by the apocalyptic vision of the social cataclysm. The road to social reform is flat and dusty; the journey along it is hard and dull. It is a wise instinct, therefore, that moves the socialists who have become social reformers to cling to the earlier vision and intone, as of old, their imprecatory psalms. But the contrast between their policies and their theories, between what they do and what they say, tempts one to say of them, inverting the Biblical quotation: "The hands are the hands of Jacob, but the voice is the voice of Esau." 


\section{INDEX}

Adams, Chas. F., 165

Adams, John, 164

Adams, T. S., 140, 142, 144

Agriculture, ix, 57 f., 62 ff., 70, $207,211 \mathrm{ff}$. concentration of, $57 \mathrm{ff} ., 66$ decentralization of, ix, $65 \mathrm{f}$.

Andler, Ch., II3

Aristotle, $256 \mathrm{f}$.

Ashley, Lord, 102

Ashley, W. J., 73, 133 ff.

Aveling, 2I

Babeuf, 154, 16I f., 202, 245

Bacon, Fr., 173

Baudeau, 159

Bauer, B., 278

Bebel, 87, 204, 24I

Becker, J. P., 58, 64, 124

Bernstein, Ed., 67, 93, 96, I26, 215 f., $231,288 \mathrm{f}$.

Berth, 293

Blake, William, 42, 43

Blanc, Louis, 149, 211

Blanqui, 202, 245

Böhm-Bawerk, I, 270 ff.

Bouniatian, 239

Bourgeoisie, I6-18, 34 ff., I92, 208, 226

Bowley, 138-9

Bracke, 99

Brandt, 38

Bray, 282

Bronterre, 16i

Buonarroti, I6I

Burnell, A. C., 205

Bush, W. T., 4I

Cabet, 202

Cairnes, 103-4

Calvin, 39

Campanella, T., 82
Cancrin, Count, 80

Capitalist production, 226 achievements of, $16 \mathrm{ff}$.

aera of, 35

collapse of . . x $x, 6,22$,

86,232 ff., 250 f., 290

Cataclysm, x, 22, $232 \mathrm{ff}$., $250 \mathrm{f}$.

Centralization of capital, $85 \mathrm{ff}$.

Chapman, M. W., 108

Charles I, 3I

Classes, 16,18

revolutionary, 173

abolition of, $193,195 \mathrm{ff}$.

Class-consciousness, xi, 18, 23

Class doctrines, 186

Class interests, $213 \mathrm{f}$.

Class struggle, xi, $16 \mathrm{ff} ., \quad 74$, I 50 ff., I8I ff., I 90 ff., I 196 ff., 249

intensity of . . $213 \mathrm{ff}$.

in America, $216 \mathrm{ff}$.

Class struggles and classes, abolition of, 193

Commercial crises, $x, 2$ Iff., $116,226 \mathrm{ff}$.

Common interests, 215-16

Commons, J. R., 218 ff., 223

Concentration of production, $18,47,52,55 \mathrm{ff}$. in agriculture, $57 \mathrm{ff} ., 66$

Conrad, J., 72, 73, 244

Considérant, $148 \mathrm{ff}$., 202

Constitutional position of capital, 223

Cremieux, 211

Crothers, S. M., 145, 235 f.

Darwin, 188-9

David, 68, 127

Decentralization of agriculture, ix, $65 \mathrm{ff}$.

De Leon, 29, 82, 199 
De l'Eure, Dupont, 2 I I

Despotism as a revolutionary policy, 195

Dialectic method, 25I-2

Dictatorship of the proletariat, vii, 193 f., I 95 ff., $245 \mathrm{f}$.

Diehl, 255, 278

Dietzgen, J., 64

\section{Eccarius, J. S., 59}

Economic interpretation of history, vi-vii, $x, x i i i, x i v, 6$, IO-II, 25 ff., 39 f., 44-45, $246 \mathrm{ff}$., $251,286 \mathrm{ff}$.

Economic tendencies, 2 II f., $225,234,239,287$

Eden, Sir Frederick, 75

Ellis, E. J., 43

Enfentin, 152

Engels, F., xi, 5, 8, I4, 21, 23, $25,28,29,34,39,40,45,57$, 63 f., 84, I22, I29 f., I5I, I83, I 89 f., I97, 227 f., 237 f., $244,248,253,264,273$

Espinas, 162

Expropriation of the means of production, $6,22,86,290$

Farmer class, 58, 60, 62 f., 69, $207,211 \mathrm{ff}$.

Ferri, 29I

Feuerbach, L., 44, I72 ff., I8I

Fisher, P., 7

Flocon, 211

Fourier, II3, I50, 202

Fournière, 162

Foxwell, 3

Free trade, 249

Freiligrath, $243 \mathrm{f}$.

Future organization of society, 23

Giffen, Sir Robert, 122, 135-7

Goethe, 32, 99, 163, 224

Gompers, 291

Goodnow, xiv

Goshen, Viscount, 9I f.

Grün, K., I73, I80, I82-3

Guild system, 7I f.
Guizot, I3, I52, I53, I88, I94

Gutenberg, 204

Hadley, 224

Haller, L. v., $166 \mathrm{ff}$.

Hammacher, 244, 252

Harris, I03

Hauptmann, I3I

Hegel, I 10, I88-9, 191, 248, 279

Heine, I3I

Hepner, 24I

Herwegh, G., 179

Hertz, Fr., 67

Hess, M., I73, 179-80, I8I

Hughan, 239

Hutten, Ulrich, 36

Increasing misery, ix, 19, $98 \mathrm{ff}$. Industrial reserve army, II I ff. Industrial revolution, 78, 99 ff., I I I

International, 58 f., 123

Iron law of wages, $99 \mathrm{ff}$., I 10

James, William, 4I

Jefferson, 165

Jones, E., 243

Just distribution, $28 \mathrm{r}-2$

Kant, 243

Kautsky, K., 23, 61, 63, 68 f., $71,97,145,149,151,188$, 200,221 f., 233 ff., 250 , $287 \mathrm{ff}$.

Kisseleff, Count, 80

Kriege, H., 279

Kugelman, 188

Labriola, I49, 188

Lafargue, 64

Lange, F. A., 189

Langsdorff, v., 130

Lassalle, $99 \mathrm{f}$., i Io

Lea, H. C., $36 \mathrm{ff}$.

Lengerke, A. v., 129

Leontyeff, 168

Leo X, 36

Le Rossignol, 3, 25, 99

Leroux, P., 2

Lescure, 239

Levasseur, 140 
Levi, L., 122

Levine, 293

Lewis, 84

Liebknecht, 26, 27, 59 f., 24I

Linguet, 159-60

Loria, 205, 265

Louis Philippe, 208, 2 II

Louis Napoleon, 29, 60, 82, 199, 208 ff., 2 I I

Louis XIV, 3I

Lüning, 175

Luther, 36 ff., 169 ff.

Luxemburg, R., 250, 283

MacCrosty, 53-54

Madison, James, 163

Mallock, W. H., 99

Malthus, IOI, III, I89

Manu, Laws of, 205

Martineau, H., 107, I14

Masaryk, T., 30, 252

Medizval industry, $7 \mathrm{I} \mathrm{ff}$.

Mehring, F., 126

Melanchthon, I70

Menger, 3, I13

Merivale, I I2-I3

Mohl, R. v., 102

Moody, Wm. Vaughn, 216

More, Th., xi f.

Morris, William, 43

Muenzer, Thomas, 284

Murner, T., 38

Nicholas I, 80

Nichols, Sir George, 77

Overproduction, 20, $226 \mathrm{ff}$.

Owen, R., 202

Paris Commune, 247

Pecqueur, 48, 49, 149

Permanent revolution, 193

Petty, Sir Wm., 128

$\mathrm{Ph}$ il os ophy of revolution, I 84 ff., 245

Plekhanoff, 152

Political philosophy, $185 \mathrm{f}$.

Political power, 193 conquest of . . vii, 23 ,

Price, 259-60
Profit, average rate of, 264

Proletariat, 18, 23, 60, 70 f., 79, 82 ff., 176 ff., $192-3$ ff., 213 , 260

American, $220 \mathrm{f}$.

Leadership of, 218

Proletarization of the farmer class, ix, 50, $60 \mathrm{f}$., $63 \mathrm{ff}$., 70

Proletarization of the masses, 22, 23, $70 \mathrm{ff}$.

Proudhon, 190

Pütmann, 45

Rae, 3

Rau, K. H., 102

Rauchberg, 35

Reformation, $34 \mathrm{ff}$.

Revisionism, v, xi, 292

Revolution-French, $152 \mathrm{ff}$., I $60 \mathrm{ff}$.

French, February, $208 \mathrm{ff}$.

German, 172 ff., I84

Industrial, 78, 99 ff., II I

Permanent, 193

Social, x, 22, 232 ff., $250 \mathrm{f}$.

- Philosophy of, $184 \mathrm{ff}$., 245

methods of . . . I93 ff., $245 \mathrm{f}$.

Paris Commune, 247

Revolutionary illusions admitted, 253

Revolutionary terrorism, 195

Ricardo, I10, 255, 264, 279

Richter, I30

Rodbertus, 230, 265

Rollin, Ledru, 2 I I

Rucherath, J., 40

Ruge, A., I82, 183

Ruskin, 3

St. Augustine, 39

St. Just, 154

Saint-Simon, 152

St. Thomas, 39

Sanial, 240

Schanz, 72

Schapiro, I7I

Schiller, I62

Schippel, 68 
Schönlank, 62, 126

Schultze-Gaevernitz, 47, 100 f.

Schwedler, I3I

Scientific socialism, vi, vii, xi, 6, II 13 ff., 39

Scotus Erigena, 39

Seligman, E. R. A., I, 30-3I, $43,50-51,67$

Senior, N., I08, I12, 123, 28I

Shaw, Bernard, 8

Simkhovitch, xv, 169, 202, 203 , 244

Simons, I64

Sismondi, S. de, II3, I49, 227

Slavery as an economic necessity, $280 \mathrm{f}$.

Smith, Monroe, xv, I76

Smith, E. J., 54

Social justice, xi, 3, 8, 9 ff., 50, $184,278 \mathrm{ff}$.

Social revolution, vi f., 15,23 , 228, $241 \mathrm{ff}$., 293

Solidarity of classes, $199 \mathrm{ff} ., 212$

Solncev, 132-3

Sombart, I, II, 56, 79, 83, 236

Sorel, 293

Sorge, 64

Spargo, 243

Spinoza, 29, 175, 199

Stammler, I, 3I, 252

Standard of living, past, $74 \mathrm{ff}$., IOI ff. present, I3I ff.

Stein, L. v., $174 \mathrm{ff}$.

Stirling, 106

Stone, N. S., 15

Struve, P. v., 127, 178, 252, 29r

Sumner, I42-4

Surplus value, $262 \mathrm{ff}$.

Syndicalism, v, xi, 292
Szeliga, 278

Tcherkesoff, W., I48, 149

Ten-hour bill, 28I

Theory of population, I Io ff.

Theory of value, $2 \mathrm{ff}$., $254 \mathrm{ff}$., 278

Theory of wages, 99-100, IIII9, 275-6

Thompson, W., 3, 202

Townsend, J., 107

Trade unionism in America, $221 \mathrm{ff}$.

Trusts, 22, $53 \mathrm{ff}$.

Tugan-Baranowsky, 203, 236, 239

Untermann, 252

Ure, A., 108, I10, III f., I23

Utopian socialism, xi, 4, 8, II

Vidal, 149

Von der Goltz, 130

Wage-fund theory, $103 \mathrm{ff}$.

Wagner, Adolph, 2, 87

Walling, 29I

Ward, L. F., I 88

Webb, 105-7, 136, 137

Weitling, 202, 247

Wernicke, J., 57

Wilde, Oscar, 43

Willich, 253

Woerishoffer, Carola, xv

Wolf, J., II f.

Wolff, J. W., ror

Woltman, 30

Wright, C. D., I4I ff.

Zablocki-Dessyatkovski, 80 


\section{A CATALOGUE OF \\ WILLIAMS \& NORGATE'S PUBLICATIONS}

ADDIS (W. E.), M.A. Hebrew Religion to the Establishment of Judaism under Ezra. Crown 8vo, cloth. 4s. 6d. net. See Crown Theological Library, p. 32.

AINSWORTH DAVIS and H. J. FLEURE. Patella (the Common Limpet). With 4 Plates. 2s. 6d. net. See Liverpool Marine Biology Committee Memoirs, p. 37.

ALLIN (Rev. THOS.). Universalism asserted as the Hope of the Gospel on the Authority of Reason, the Fathers, and Holy Scripture. With a Preface by Edna Lyall, and a Letter from Canon Wilberforce. Crown 8vo, cloth. 2s. 6d. net.

ALVIELLA (Count GOBLET D'). Lectures on the Origin and the Growth of the Conception of God, as Illustrated by Anthropology and History. Translated by the Rev. P. H. Wicksteed. Hibbert Lectures, 189r. Cloth, Library Edition, ros. 6d. Popular Edition, 3s. 6d.

ANGLICAN LIBERALISM. By Twelve Churchmen. Rev. Hubert Handley, Prof. F. C. Burkitt, M.A., D.D., Rev. J. R. Wilkinson, M.A., Rev. C. R. Shaw Stewart, M.A., Rev. Hastings Rashdall, D.Litt., D.C.L., Prof. Percy Gardner, D.Litt., LL.D., Sir C. T. Dyke Acland, Rev. A. J. Carlyle, M.A., Rev. H. G. Woods, D.D., Rev. A. A. Caldcott, D.Litt., D.D., Rev. W. D. Morrison, LL.D., Rev. A. L. Lilley, M.A. Crown 8vo, cloth. 4s. 6d. net. ASHWORTH (J. H.), D.Sc. Arenicola (the Lug-Worm). With 8 Plates. 4s. 6d. net. See Liverpool Marine Biology Committee Memoirs, p. 37 .

AVEBURY (Lord), D.C.L., F.R.S. Prehistoric Times, as Illustrated by Ancient Remains and the Manners and Customs of Modern Savages. 6th Edition, revised, with 239 Illustrations, a large number of which are specially prepared for this Edition. Demy 8vo, cloth, gilt tops. Cheap Popular Edition, 7s. 6d. net.

AVESTI, PAHLAVI, and ANCIENT PERSIAN STUDIES in Honour of the late Shanıs-ul-Ulama Dastur Peshotanji Behramji Sanjana, M.A., Ph.D. Paper cover, I 2s. 6d. net; cloth, I 3s. 6d. net. BACON (Professor B. W.). The Making of the New Testament. F'cap. 8vo, cloth, xs. net ; leather, 2s. 6d. net. Forming Vol. ${ }^{6} 6$ in the Home University Library ; for list, see p. ${ }_{3}^{6}$.

BACON (ROGER), the "Opus Majus" of. Edited, with Introduction and Analytical Table, by John Henry Bridges, Fellow of Royal College of Physicians, sometime Fellow of Oriel College. Complete in 3 vols., 3 rs. 6d. ; Vol. III. sold separately, 7s. 6d. 
BALSILLIE (DAVID), M.A. An Examination of Professor Bergson's Philosophy. Crown 8vo, cloth. 5s. net.

BARRETT (Sir W. F.), F.R.S. Psychical Research. F'cap. 8vo, cloth, Is. net ; leather, 2s. $6 \mathrm{~d}$. net. Forming Vol. 28 in the Home University Library ; for list, see p. 35 .

BARRY (WILLIAM), D.D. The Papacy and Modern Times (r303-r870). F'cap. 8vo, cloth, is. net; leather, 2s. 6d. net. Forming Vol. 14 in the Home University Library ; for list, see p. 35 . BAUR (F. C.). Church History of the First Three Centuries. Translated from the Third German Edition. Edited by Rev. Allan Menzies. 2 vols. 8vo, cloth. I2s.

Paul, the Apostle of Jesus Christ, his Life and Work, his Epistles and Doctrine. A Contribution to a Critical History of Primitive Christianity. Edited by Rev. Allan Menzies. 2nd Edition. 2 vols. 8vo, cloth. I2s.

BAYLEY (HAROLD). The Lost Language of Symbolism. With above 1400 Symbols. 2 Vols. Medium 8vo, cloth. 25 s. net.

BEARD (Rev. Dr C.). Lectures on the Reformation of the Sixteenth Century in its Relation to Modern Thought and Knowledge. Hibbert Lectures, I883. 8vo, cloth. Ios. 6d. Cheap Edition, 3rd Edition, 3s. 6 d.

The Universal Christ, and other Sermons. Crown 8vo, cloth. 7 s. 6 d.

BEGBIE (HAROLD). See "Character and Life," p. 4.

BELLOC (HILAIRE), M.A. The French Revolution. (With Maps.) F'cap. 8vo, cloth, rs. net ; leather, 2s. 6d. net. Forming Vol. 2 in the Home University Library; for list, see p. 34 .

Warfare in England. (With Maps.) F'cap. 8vo, cloth, Is. net; leather, 2s. 6d. net. Vol. $5 \mathrm{I}$ in the Home University Library; for list, see p. 36 .

BENEDICT (F. E.), Ph.D. Elementary Organic Analysis. Small 8vo. Pages vi +82 . I 5 Illustrations. 4s. 6d. net.

BERGEY (D. G.). Handbook of Practical Hygiene. Small 8vo. Pages v + 164. 6s. 6d. net.

BEVAN (Rev. J. O.), M.A., F.G.S. The Genesis and Evolution of the Individual Soul scientifically Treated. Including also Problems relating to Science and Immortality. Crown 8vo, cloth. 2s. 6d. net.

BIBLE. Translated by Samuel Sharpe, being a Revision of the Authorised English Version. 6th Edition of the Old, roth Edition of the New Testament. 8vo, roan. $5 \mathrm{~s}$.

BILTZ (HENRY). The Practical Methods of determining Molecular Weights. Translated by Jones. Small 8vo. Pages viii +245 . 44 Illustrations. 8s. 6d. net.

BLACKBURN (HELEN). Women's Suffrage. A Record of the Women's Suffrage Movement in the British Isles, with a Biographical Sketch of Miss Becker. With portraits. Crown 8 vo, cloth. $6 \mathrm{~s}$. 
BOIELLE (JAS.). French Composition through Lord Macaulay's English. Edited, with Notes, Hints, and Introduction, by the late James Boïelle, B.A. (Univ. Gall.), Officier d'Académie, Senior French Master, Dulwich College, etc., etc. Crown 8vo, cloth. Vol. I. Frederick the Great. 3s. Vol. II. Warren Hastings. $3^{\text {s. }}$ Vol. III. Lord Clive. 3s.

See Victor Hugo, "Les Misérables" and " Notre Dame."

BOLTON. History of the Thermometer. I 2 mo. 96 pages. 6 Illustrations. 4 s. $6 \mathrm{~d}$. net.

BOUSSET (Prof. WILHELM). Jesus. Translated by Janet Penrose Trevelyan, and edited by Rev. W. D. Morrison, LL.D. Crown 8vo. 3s. 6d. net. Forming Vol. 14 in the Crown Theological Library; see p. 32.

BRADLEY (A. G.). Canada. F'cap. 8vo, cloth, Is. net; leather, 2s. 6d. net. Forming Vol. 34 in the Home University Library; see list, p. 35 .

BRAUNS (Dr REINHARD). The Mineral Kingdom. The author is the well-known Professor of Mineralogy in the University of Bonn. Translated with additions by L. J. Spencer, M.A., F.G.S., Assistant in the Mineral Department of the British Museum. In demy 4to, comprising 9 I full-page plates beautifully executed in colours, 73 of which are chromo-lithographs, 18 photographic reproductions, and 275 figures in the text. Bound in half-morocco. $£^{2}, 16 \mathrm{~s}$. net.

BREMOND (HENRI). The Mystery of Newman. With Introduction by the late Rev. George Tyrrell, M.A. Medium 8vo, cloth. Ios. 6d. net.

BREWSTER (H. B.). The Theories of Anarchy and of Law. A Midnight Debate. Crown 8vo, parchment. ${ }^{5}$ s.

The Prison. A Dialogue. Crown 8vo, parchment. 5 s. The Statuette and the Background. Crown 8vo, parchment. $4 \mathrm{~s}$.

BREWSTER (Prof. W. T.), Editor of the Home University Library ; for list, see p. 34 .

BRUCE (ALEX.), M.A., M.D., F.R.C.P.E. A Topographical Atlas of the Spinal Cord. F'cap. folio, half-leather. $£^{2}$, 2s. net. BRUCE (Dr W. S.), F.R.S.E. Polar Exploration. (With Maps.) F'cap. 8vo, cloth, Is. net; leather, 2s. 6d. net. Forming Vol. 8 in the Home University Library; for list, see p. 34.

CAMPBELL (Rev. COLIN), D.D. The First Three Gospels in Greek. Arranged in parallel columns. 2nd Edition, Revised. Crown 8vo, cloth. 3s. 6d. net.

CARPENTER (Rt. Rev. W. BOYD). Some Pages of My Life. By the present Canon of Westminster and late Bishop of Ripon. With portrait of the author as frontispiece, and other interesting portraits. Medium 8vo, cloth, gilt top. I 5 s. net. 
CARTWRIGHT (Captain) and His Labrador Journal. Edited by Charles Wendell Townsend, M.D. With an Introduction by Dr Wilfred T. Grenfell. With Illustrations from old engravings, photographs and a map. Crown 8vo, cloth. 5s. net.

CECIL (Lord HUGH), M.A., M.P. Conservatism. F'cap. 8vo, cloth, Is. net; leather, 2s. 6d. net. Forming Vol. II in the Home University Library ; for list, see p. 35.

CHADWICK(HERBERT CLIFTON). Antedon. With 7 Plates. 2s. 6d. net. See Liverpool Marine Biology Memoirs, p. 37.

Echinus. With 5 Plates. Price 2s. net. See Liverpool Marine Biology Memoirs, p. 36.

CHANNING'S COMPLETE WORKS. Including "The Perfect Life," with a Memoir. Centennial Edition. 4to Edition. Cloth. 7s. 6d.

CHAPMAN (Prof. S. J.), M.A. Elements of Political Economy. F'cap. 8vo, cloth, Is. net; leather, 2s. 6d. net. Forming Vol. 59 in the Home University Library; for list, see p. 36.

CHARACTER AND LIFE: A Symposium. By Dr Alfred Russel Wallace, John A. Hobson, Harold Begbie, Walter Crane, and the late Dr Emil Reich. Arranged by Percy L. Parker, Editor of "Public Opinion." Crown 8vo, cloth. 3s. 6d. net.

CHEYNE (Rev. T. K.), D. Litt., D.D. Bible Problems and the New Material for their Solution. A Plea for Thoroughness of Investigation, addressed to Churchmen and Scholars. Crown 8vo. 45. 6d. net. See Crown Theological Library, p. 32.

CHILD AND RELIGION, THE. Essays. By Prof. Henry Jones, M.A., LL.D., University of Glasgow ; C. F. G. Masterman, M.A.; Prof. George T. Ladd, D.D., LL.D. ; Rev. F. R. Tennant, M.A., B.Sc.; Rev. J. Cynddylan Jones, D.D.; Rev. Canon Hensley Henson, M.A. ; Rev. Robert F. Horton, M.A., D.D. ; Rev. G. Hill, M.A., D.D.; Rev. J. J. Thornton; Rev. Rabbi A. A. Green; Prof. Joseph Agar Beet, D.D. Edited by Thomas Stephens, B.A. Crown 8vo. 5s. net. See Crown Theological Library, p. 32.

COIT (STANTON), Ph.D. National Idealism and a State Church. Demy 8vo, cloth. 7s. 6d. net.

National Idealism and the Book of Common Prayer. An Essay in Re-Interpretation and Revision. Demy 8vo, cloth. ros. 6d. net.

COLBY (ALBERT LADD). Reinforced Concrete in Europe. Demy 8vo, cloth. r4s. 6d. net.

COLE (FRANK J.), and JAMES JOHNSTONE. Pleuronectes. With $x$ r Plates. 7s. net. See Liverpool Marine Biology Memoirs, p. 36.

COLLINS (F. H.). An Epitome of the Synthetic Philosophy.

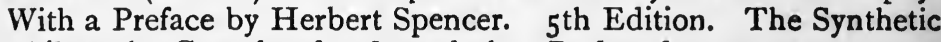
Philosophy Completed. 8vo, cloth. Reduced to 5 s. net.

I4 Henrietta Street, Covent Garden, London, W.C. 
CONYBEARE (F. C.), M.A. The Ring of Pope Xystus : a collection of Aphorisms and Short Sayings in use among Christian Communities in the Second Century. Beautifully printed on handmade paper. 4s. 6d. net.

CORNILL (Prof. CARL). The Introduction to the Canonical Books of the Old Testament. Demy 8vo, cloth. Ios. 6d. net. See Theological Translation Library, p. 39.

CRANE (WALTER), contributor to "Character and Life," see p. 4. CREIGHTON (Mrs). Missions: their Rise and Development. F'cap. 8vo, cloth, Is. net ; leather, 2s. 6d. net. Forming Vol. 6o in the Home University Library; for list, see p. 36.

CREIGHTON (CHAS.), M.D. Cancer and other Tumours of the Breast. Researches showing their true seat and cause, The Author was sometime Demonstrator of Anatomy, Cambridge Medical School, and is the author of "Bovine Tuberculosis in Man," etc. With 24 Lithographic Plates containing ${ }_{3} 8$ figures from the Author's drawings. Royal 8vo, cloth. I 2s. 6d. net.

Contributions to the Physiological Theory of Tuberculosis. Royal 8vo, cloth. 12s. 6d. net.

CUSSANS (MARGARET), B.Sc. Gammarus. With 4 Plates. 2s. net. See Liverpool Marine Biology Memoirs, p. 37.

DAKIN (W. J.), M.Sc. Pecton. With 9 Plates. 4s. 6d. net. See Liverpool Marine Biology Memoirs, p. 37.

DARBISHIRE (OTTO V.). Chondrus. With 7 Plates. 2s. 6d. net. See Liverpool Marine Biology Memoirs, p. 36.

DAUDET (A.). Contes Militaires. 2s. 6d. See Army Series, p. 3 I. DAVENPORT (CHARLES BENEDICT). Heredity in relation to Eugenics. The Author is Director, Department of Experimental Evolution, Cold Spring Harbour, Long Island, N.Y.; Secretary of the Eugenics Section American Breeders' Association. With Diagrams and Coloured Plate. Demy 8vo, cloth. 8s.6d. net. DAVIDS (Mrs RHYS), M.A. Buddhism. F'cap. 8vo, cloth, Is. net; leather, 2s. 6d. net. Forming Vol. 47 in the Home University Library; for list, see p. 35 .

DAVIDS (T. W. RHYS). Lectures on Some Points in the History of Indian Buddhism. The Hibbert Lectures, 188 r. 2nd Edition. Demy 8vo, cloth. Library Edition, Ios. 6d. Cheap Edition, 3s. 6d. DAVIS (H. W. C.), M.A. Mediæval Europe. (With Maps.) F'cap. 8vo, cloth, Is. net; leather, 2s. 6d. net. Forming Vol. I 3 in the Home University Library; for list, see p. 35.

DELBOS (L.). Nautical Terms in English and French and French and English. With Notes and Tables. For the use of Naval Officers and Naval Cadets. By Leon Delbos, M.A., of H.M.S. Britannia, Dartmouth. 4th Edition, thoroughly revised and considerably enlarged, with additional Plates. Crown 8vo, sloth, 7s. 6d. net. 
DELBOS (L.). The Student's Graduated French Reader. Remodelled and rewritten. Edited, with Notes and a Complete Vocabulary. First Year-Part I. Anecdotes, Tales, and Exercises. Part II. Tales, Historical Pieces, and Exercises. Is. 6d. each. Second Year-Parts I. and II. in the Press.

DELITZSCH (Dr FRIEDRICH). Babel and Bible. Authorised Translation. Edited, with an Introduction, by Rev. C. H. W. Johns. Crown 8vo, with 77 Illustrations, cloth. 4s. 6d. net. See Crown Theological Library, p. $3 \mathrm{I}$.

DEWALL (JOHANNES V.). Auf Verlornem Posten and Nazzarena Danti. 3s. See Army Series, p. 3r.

DICKSON (H. N.), D.Sc. Climate and Weather. F'cap. 8vo, cloth, Is. net; leather, 2s. 6d. net. Forming Vol. $3^{6}$ in the Home University Library; for list, see p. 35 .

DILLMANN (A.). Ethiopic Grammar. Translated from C. Bezold's Second German Edition. By Rev. J. A. Crichton, D.D. With Index of Passages, Philological Tables, etc. I vol., royal 8vo. $25 \mathrm{~s}$. net.

DIPAVAMSA (THE): A Buddhist Historical Record in the Pali Language. Edited, with an English Translation, by $\mathrm{Dr} \mathrm{H}$. Oldenberg. 8vo, cloth. 2 Is.

DOBSCHU்TZ (ERNST VON), D.D. Christian Life in the Primitive Church. The Author is Professor of New Testament Theology in the University of Strassburg. Translated by Rev. G. Bremner, and edited by the Rev. W. D. Morrison, LL.D. Demy 8vo, cloth. 1os. 6d. See Theological Translation Library, New Series, p, 38.

DOLE (CHARLES F.). The Ethics of Progress, or the Theory and the Practice by which Civilisation proceeds. Small demy 8vo, cloth. 6s. net.

DRUMMOND (Dr JAMES), LL.D. Philo Judæus; or, The Jewish Alexandrian Philosophy in its Development and Completion. 2 vols. 8vo, cloth. 2 Is.

Via, Veritas, Vita. Lectures on Christianity in its most Simple and Intelligible Form. Hibbert Lectures, 1894. Demy 8vo. Library Edition, ros. 6d. Cheap Edition, 3s. 6d.

DUNCAN (DAVID), LL.D. The Life and Letters of Herbert Spencer. With I 7 Illustrations. Cheap Re-issue. 6s. net.

EMERY (F. B.), M.A. Elementary Chemistry. With numerous Illustrations. 8s. 6d. net.

ENGELHARDT (V.). The Electrolysis of Water. 8vo. Pages $\mathrm{X}+\mathrm{I} 40$. 90 Illustrations. 5s. net.

ENGLAND AND GERMANY. By Leaders of Public Opinion in both Empires, among whom may be mentioned:-Rt. Hon. Arthur J. Balfour, Viscount Haldane of Cloan, Rt. Hon. A. Bonar Law, Baron Alfred von Rothschild, Rt. Hon. Herbert Samuel, Sir Rufus Isaacs, Norman Angell, J. Ramsay MacDonald, M.P., J. A. Spender, Excell. Karl Galster, Ernst Basserman, Professor Dr Riesser, Baron Wilhelm von Pechmann, Professor Wilhelm Wundt, 
Dr Walther Rathenau, August Thyssen, sen., His Excellency Dr Adolf Wermuth, Excell. von Holleben, etc. With Portraits. Stiff Wrapper. 1s. net.

ERMAN'S EGYPTIAN GRAMMAR. Translated, under Professor Erman's supervision, by J. H. Breasted, Professor of Egyptology in the University of Chicago. Crown 8vo, cloth. I8s.

ERSKINE (Prof. J.) and Prof. W. P. TRENT. Great Writers of America. F'cap. 8vo, cloth, is. net ; leather 2s. 6d. net. Forming Vol. $5^{2}$ in the Home University Library; for list, see p. 36.

EUCKEN (Dr RUDOLF), Jena. The Life of the Spirit. An Introduction to Philosophy. Second Edition. Third Impression. 8vo, cloth. 4s. 6d. net. See Crown Theological Library, p. 32.

The Truth of Religion. Now first translated from the second and revised edition by Rev. W. Tudor Jones, Ph.D., with a special preface by the Author. Demy 8vo, cloth. I2s. 6d. net. See Theological Translation Library, New Series, p. 39.

EUGENE-FASNACHT (G.). Eugène's Student's Comparative Grammar of the French Language, with an Historical Sketch of the Formation of French. The Author was for many years French Master, Westminster School. For the use of Public Schools. With Exercises. 23rd Edition, thoroughly revised. Square crown 8vo, cloth, 5s. ; or separately, Grammar, 3s. ; Exercises, 2s. 6d.

French Method. Elementary French Lessons preparatory to the same Author's Grammar. I8th Edition. Cloth. Is. 6d.

EVANS (GEORGE). An Essay on Assyriology. With 4to Tables of Assyrian Inscriptions. 8vo, cloth. $5 \mathrm{~s}$.

EWALD'S (Dr H.) Commentary on the Prophets of the Old Testament. Translated by the Rev. J. F. Smith. [Vol. I. General Introduction, Yoel, Amos, Hosea, and Zakharya 9-II. Vol. II. Yesaya, Obadya, and Mikah. Vol. III. Nahûm, Ssephanya, Habaqqûq, Zakhârya, Yéremya. Vol. IV. Hezekiel, Yesaya xl.-lxvi. Vol. V. Haggai, Zakharya, Malaki, Jona, Baruc, Daniel, Appendix and Index.] 5 vols. 8vo, cloth. 30s. See Theological Translation Library, Old Series, p. 39.

Commentary on the Psalms. Translated by the Rev. E. Johnson, M.A. 2 vols. $8 \mathrm{vo}$, cloth. I $2 \mathrm{~s}$.

Commentary on the Book of Job, with Translation. Translated from the German by the Rev. J. Frederick Smith. 8vo, cloth. 6s. FAGUET (Prof. EMILE), of the French Academy. Initiation into Philosophy. Translated by Sir Home Gordon, Bart. Crown 8vo, cloth. 2s. 6d. net.

FARNELL (L. R.), D. Litt. The Evolution of Religion: an Anthropological Study. Crown 8vo, cloth. 45. 6d. net. See Crown Theological Library, p. 32.

The Higher Aspects of Greek Religion. Lectures delivered in Oxford and London. Being Vol. I of New Series of Hibbert Lectures. Demy 8vo, cloth. 6s. net. See Hibbert Lectures, p. 34 . 
FARQUHARSON (Rt. Hon. ROBERT), LL.D. The House of Commons from Within, and other Reminiscences. With Portrait by J. S. Sargent, R.A. Never before published. Medium 8vo. 7s. 6d. net.

In and Out of Parliament. With a number of portraits and caricatures. Medium 8vo, cloth. I 2s. 6d. net.

FARRIE (HUGH). Highways and Byways in Literature. A volume of original Studies. Demy 8vo, cloth. 5s. net.

FINDLAY (Prof. J. J.), M.A., Ph.D. The School. An Introduction to the Study of Education. F'cap. 8vo, cloth, Is. net; leather, 2s. 6d. net. Forming Vol. $3^{8}$ in the Home University Library ; for list, see p. 35.

FISCHER (Prof. EMIL), of Berlin University. Introduction to the Preparation of Organic Compounds. Translated with the Author's sanction from the new German edition by R. V. Stanford, B.Sc., Ph.D With figures in the text. Crown 8vo, cloth. 4s. net.

FISHER (HERBERT), M.A., F.B.A., Editor, Home University Library ; for list, see p. 34.

FOUR GOSPELS (THE) AS HISTORICAL RECORDS. 8vo, cloth. I 5 s.

FOWLER (W. WARDE), M.A. Rome. F'cap. 8vo, cloth, Is. net; leather, 2s. 6d. net. Forming Vol. 42 in the Home University Library ; for list, see p. 35.

FOX (FRANK). Problems of the Pacific. By the author of "Ramparts of Empire," etc. Demy 8vo, cloth. With Map. 7s. 6d. net. GAMBLE (Prof. F. W.), D.Sc., F.R.S. The Animal World. With Introduction by Sir Oliver Lodge. Many Illustrations. F'cap. 8vo, cloth, is. net; leather, 2s. 6d. net. Forming Vol. 19 in the Home University Library; for list, see p. 35.

GARDNER (Prof. PERCY), D.Litt., F.B.A., Oxford. Modernity and the Churches. 4s. 6d. net. See Crown Theological Library, p. 32.

The Religious Experience of St Paul. Crown 8vo, cloth. 5s. net. See Crown Theological Library, p. 33.

GELDART (W. M.), M.A., B.C.L. Elements of English I.aw. F'cap. 8vo, cloth, Is. net ; leather, 2s. 6d. net. Forming Vol. 30 in the Home University Library; for list, see p. 35 .

GIBSON (R. J. H.) and HELEN P. AULD, B.Sc. Codium. With 3 Plates. Price Is. 6d. net. See Liverpool Marine Biology Memoirs, p. 36 .

GILES (H. A.), LL.D. The Civilisation of China. By the wellknown Professor of Chinese in the University of Cambridge. F'cap. 8vo, cloth, Is. net; leather, 2s. 6d. net. Forming Vol. 25 in the Home University Library; for list, see p. 35 .

GILL (CHARLES). The Book of Enoch the Prophet. Translated from Ethiopic MS. in the Bodlcian Library, by the late Richard Laurence, LL.D., Archbishop of Cashel. The Text corrected from his latest Notes by Charles Gill. Re-issue, 8vo, cloth. 5 s.

I4 Henrietta Street, Covent Garden, London, W.C. 
GOLDAMMER (H.). The Kindergarten. A Guide to Fröbel's Method of Education. 2 vols. in I. 120 pp. of Illustrations. $8 \mathrm{vo}$, cloth. Ios. 6d.

GOOCH (G. P.), M.A. The History of our Time, I885-1911. F'cap. 8vo, cloth, rs. net; leather, 2s. 6d. net. Forming Vol. 23 in the Home University Library; for list, see p. 35.

GRAVELY (F. H.), M.Sc. Polychaet Larvae. With 4 plates. 2s. 6d. net. See Liverpool Marine Biology Committee Memoirs, p. 37.

GREEN (Rt. Rev. A. V.), D.D., Bishop of Ballarat. The Ephesian Canonical Writings: Being the Moorhouse Lectures for 1910. Crown 8vo, cloth. 5 s. net.

GREEN (Mrs J. R.). Irish Nationality. F'cap. 8vo, cloth, 1s. net; leather, 2s. 6d. net. Forming Vol. 6 in the Home University Library ; for list, see p. 34 .

GREGORY (Prof. J. W.), F.R.S. The Making of the Earth. (With 38 Maps and Figures.) F'cap. 8vo, cloth, Is. net; leather, 2s. 6d. net. Forming Vol. 53 in the Home University Library; for list, see p. 34 .

GRIEBEN'S ENGLISH GUIDES. Practical and handy ; size, suitable for the pocket, $6 \frac{1}{4}+4 \frac{1}{4}$, and bound in cloth.

Switzerland. A practical guide with seven Maps. Cloth. 3s. net. Norway and Copenhagen. With six Maps. Cloth. 3s. net.

Ostend and other Belgium Watering Places. With two Maps. Cloth. Is. 6d. net.

Lakes of Northern Italy. With Maps. Cloth. 3s. net.

The Rhine. With Maps. Cloth. 3s. net.

North Sea Watering Places. Cloth. 3s. net.

Belgium. With Maps. Cloth. 3s. net.

Brussels and Antwerp. With Maps. Cloth. Is. 6d. net.

Holland. With Maps. Cloth. 3s. net.

The Riviera. With Maps. Cloth. 3s. net.

Winter Sports in Switzerland. A practical guide for those visiting Switzerland in the winter. With Map. Cloth. 3s. net.

Dresden and Environs. With Maps. Cloth. Is. 6d. net.

Munich and Environs. With Maps. Cloth. Is. 6d. net.

Nuremberg and Rothenburg on the Tauber. With 2 Maps. Is. $6 \mathrm{~d}$. net.

The Dolomites. With 3 Maps. 3s. net.

GUPPY (H. B.), M.B., F.R.S.E. Studies in Seeds and Fruits. An Investigation with the Balance. Demy $8 \mathrm{vo}$, cloth, nearly $600 \mathrm{pp}$. I5s. net.

HAERING (Prof. THEODOR). Ethics of the Christian Life. Translated by Rev. G. Bremner, and edited by Rev. W. D. Morrison. Demy 8vo, cloth. Ios. 6d. net. See Theological Translation Library, New Series, p. 39.

HALLIGAN (JAMES EDWARD). Soil Fertility and Fertilisers. The Author is chemist in charge Louisiana State Experiment Station. With Illustrations and Tables. Demy 8vo, cloth. I4s. 6d. net.

I4 Henrietta Street, Covent Garden, London, W.C. 
HANTZSCH (A.). Elements of Stereochemistry. Translated by Wolf. 12 mo. Pages viii +206.26 Figures. 6s. 6d. net.

HARDY. Elements of Analytical Geometry. 8vo. Pages iv +365 . I63 Figures. 8s. 6d.

-Infinitesimals and Limits. Sm. I 2 mo, paper. 22 pp. 6 Figs. Is. net.

HARNACK (ADOLF), D.D. The Acts of the Apostles. Being Vol. III. of Dr Harnack's New Testament Studies. Crown 8 vo, cloth. 5s. net. Vol. 26 in the Crown Theological Library; for list, see p. 32.

Bible Reading in the Early Church. Forming Vol. V. of New Testament Studies. 5s. net. See Crown Theological Library, p. 33. The Constitution and Law of the Church in the First Two Centuries. Crown 8vo, cloth. 5s. net. Vol. $3^{\mathrm{I}}$ in the Crown Theological Library, p. 33.

The Date of the Acts and of the Synoptic Gospels. Crown 8vo, cloth. 5s. net. Forming Vol. IV. in Dr Harnack's New Testament Studies, and Vol. 33 in the Crown Theological Library, p. 33.

- History of Dogma. Translated from the Third German Edition. Edited by the late Rev. Prof. A. B. Bruce, D.D. 7 vols. 8vo, cloth, each ros. 6d. ; half-leather, suitable for presentation, r2s. 6d. See Theological Translation Library, New Series, p. 38.

- Letter to the "Preussische Jahrbücher" on the German Emperor's Criticism of Prof. Delitzsch's Lectures on "Babel and Bible." Translated into English by Thomas Bailey Saunders. 6d. net.

Luke, the Physician. Translated by the Rev. J. R. Wilkinson, M.A. Being Vol. I. of Dr Harnack's New Testament Studies. Crown 8vo, cloth. 5s. net. See Crown Theological Library, p. 32. The Mission and Expansion of Christianity in the First Three Centuries. Second, revised and much enlargèd Edition. 25 s. net. Forming Vols. 19 and 20 in Theological Translation Library, New Series ; see p. 38 .

Monasticism: Its Ideals and History; and The Confessions of St Augustine. Two Lectures. Translated into English by E. E. Kellet, M.A., and F. H. Marseille, Ph.D. Crown 8vo, cloth. 3s. 6d. net. Forming Vol. 28 in the Crown Theological Library, p. 32.

- The Sayings of Jesus. Being Vol. II. of Dr Harnack's New Testament Studies. Crown 8vo, cloth. 5s. net. Forming Vol. 23 in the Crown Theological Library, p. 32.

What is Christianity? Translated by Thomas Bailey Saunders. Third and Revised Edition. Crown 8vo. 4s. 6d. net. Forming Vol. 5 in the Crown Theological Library, p. 3I.

and Prof. W. HERRMANN, of Marburg. Essays on the Social Gospel. Crown 8vo, cloth. 4s. net. Forming Vol. 18 in the Crown Theological Library, p. 32.

HARNACK (AXEL). Introduction to the Elements of the Differential and Integral Calculus. From the German. Royal 8vo, cloth. Ios. 6d. 
HART (EDWARD), Ph. D. Chemistry for Beginners. Small $12 \mathrm{mo.}$ Vol. I. Inorganic. Pages viii +188.55 Illustrations and 2 Plates. 4th Edition. 45. 6d. net.

Vol. II. Organic. Pages iv +98 . I I Illustrations. 2s. net.

Vol. III. Experiments. Separately. 60 pages. 1s. net. Second Year Chemistry. Sm. I 2 mo. $\quad$ I 65 pp. 3 I Illus. 5 s. net. HATCH (Rev. Dr). Lectures on the Influence of Greek Ideas and Usages upon the Christian Church. Edited by Dr Fairbairn. Hibbert Lectures, 1888. 3rd Edition. 8vo, cloth. 10s. 6d. Cheap Edition, 3s. 6d.

HAUSRATH (Prof. A). History of the New Testament Times. The Time of the Apostles. Translated by Leonard Huxley. With a Preface by Mrs Humphry Ward. 4 vols. 8vo, cloth. $42 \mathrm{~s}$. (Uniform with the Theological Translation Library, Old Series.)

History of the New Testament Times. The Time of Jesus. Trans. by the Revs. C. T. Poynting and P. Quenzer. 2 vols. 8vo, cloth. I2s. See Theological Translation Library, Old Series, p. 39. HEATH (FRANCIS GEORGE). Nervation of Plants. By the well-known Author of "Our Woodland Trees," "The Fern World," etc. Well Illustrated. Crown 8vo. 3s. 6d. net.

HEBREW TEXTS, in large type for Classes: Genesis. and Edition. I6mo, cloth, Is. 6d. Psalms. I6mo, cloth. Is. Isaiah. I6mo, cloth. Is. Job. I6mo, cloth. Is.

HERDMAN (W. A.). Ascidia. With 5 Plates. 2s. net. See Liverpool Marine Biology Committee Memoirs, p. 36 .

HERFORD (Rev. R. TRAVERS). Christianity in Talmud and Midrash. Demy 8vo, cloth. I8s. net.

Pharisaism: Its Aims and its Methods. Crown 8vo, cloth. 5s. net. Forming Vol. 35 in the Crown Theological Library, p. 33.

HERRMANN (Prof. WILHELM). The Communion of the Christian with God. Translated from the new German Edition by Rev. J. S. Stanyon, M.A., and Rev. R. W. Stewart, B.D., B.Sc. Crown 8 vo, cloth. 4s. 6 d. net. Forming Vol. 15 in the Crown Theological Library, p. 32.

Faith and Morals. New Edition. Crown 8vo, cloth. 4s. 6d. net. Forming Vol. 6 in the Crown Theological Library, p. $3 \mathbf{I}$.

HEWITT (C. GORDON), B.Sc. Ligia. With ${ }_{4}$ Plates. 2s. net. See Liverpool Marine Biology Memoirs, p. 37.

HIBBERT JOURNAL : A Quarterly Review of Religion, Theology, and Philosophy. Edited by L. P. Jacks and G. Dawes Hicks. In quarterly issues, $2 \mathrm{~s}$. $6 \mathrm{~d}$. net ; or yearly volumes bound in cloth, I 2s. 6d. net. Annual Subscription, 1os. post free.

HIBBERT JOURNAL SUPPLEMENT, I909, entitled JESUS OR CHRIST? Containing i 8 Essays by leading Theologians and Thinkers. Super royal 8vo, cloth. 5s. net.

HICKSON (SYDNEY J.), D.Sc., F.R.S. Alcyonium. With 3 Plates. Price Is. 6d net. See Liverpool Marine Biology Committee Memoirs, p. 36 . 
HINKS (A. R.), M.A. Astronomy. F'cap. 8vo, cloth, Is. net; leather, 2s. 6d. net. Forming Vol. $3 \mathrm{I}$ in the Home University Library ; for list, see p. 35.

HIRST (F. W.), M.A. The Stock Exchange. F'cap. 8vo, cloth, Is. net; leather, 2s. 6d. net. Forming Vol. 5 in the Home University Library; for list, see p. 34.

HOBHOUSE (Prof. L. T.), M.A. Liberalism. F'cap. 8vo, cloth, Is. net; leather, 2s. 6d. net. Forming Vol. 2 I in the Home University Library; for list, see p. 35 .

HOBSON (J. A.), M.A. The Science of Wealth. F'cap. 8vo, cloth, Is. net; leather, 2s. 6d. net. Forming Vol. 16 in the Home University Library; for list, see p. 35 .

Character and Life. See p. 4.

HÖFER (E.). Erzählungen. 3s. See Army Series of French and German Novels, p. 3 I.

HOFF (J. H. VAN'T). Studies in Chemical Dynamics. Revised and enlarged by Ir Ernst Cohen, Assistant in the Chemical Laboratory of the University of Amsterdam. Translated by Thomas Ewan, M.Sc., Ph.D., Demonstrator of Chemistry in the Yorkshire College, Leeds. Royal 8vo, cloth. Ios. 6d.

HOLDERNESS (Sir T. W.), K.C.S.I. Peoples and Problems of India. The Author is Secretary of the Revenue, Statistics, and Commerce Department of the India Office. F'cap. 8vo, cloth, rs. net; leather, 2s. 6d. net. Forming Vol. 37 in the Home University Library; see p. 35.

HOLLINS (DOROTHEA). The Quest. A Romance of Deliverance. Demy 8vo, cloth. 4s. 6d. net.

HOME UNIVERSITY LIBRARY OF MODERN KNOWLEDGE. Every volume is specially written for this Library by a recognised authority of high standing. Each volume is complete and independent, but the series has been planned as a whole to form a comprehensive library of modern knowledge. The Library is published under the direction of Professor Gilbert Murray and Mr Herbert Fisher of Oxford, Professor J. Arthur Thomson of Aberdeen, and Professor William T. Brewster of New York. Each volume consists of $25^{6}$ pages and is issued bound in cloth at Is. net, or in leather, 2s. 6d. net. For list of volumes, see p. 34 .

HORNELL (JAMES), F.L.S. Report to the Government of Baroda on the Marine Zoology of Okhamandal in Kattiawar. With Supplementary Reports on Special Groups by other Zoologists. Demy 4to, cloth, with full-page Plates. Part I. I 5s. net.

HOWE (J. L.), Washington and Lee University. Inorganic Chemistry for Schools and Colleges. Being a Second Edition of "Inorganic Chemistry according to the Periodic Law." By F. P. Venable and J. L. Howe. Demy 8vo, cloth. I 2s. 6d. net.

HUGO (VICTOR). Les Misérables: Les Principaux Episodes. Edited, with Life and Notes, by the late J. Boïelle. 2 vols. 6th Edition. Crown 8vo, cloth. Each 3 s. 
HUGO (VICTOR). Notre Dame de Paris. Adapted for the use of Schools and Colleges. By the late J. Boïelle. 2 vols. 2 nd Edition. Crown 8vo, cloth. Each 3 s.

HUNTER (Rev. J.), D.D. De Profundis Clamavi, and Other Sermons. Large crown 8vo, cloth. 5s. net.

God and Life. A Series of Discourses. Uniform with "De Profundis Clamavi." Cloth. 5s. net.

The Coming Church. A Plea for a Church simply Christian. Cloth. Is. 6d. net.

ILBERT (Sir C. P.), K.C.B. Parliament: its History, Constitution, and Practice. F'cap. 8vo, cloth, Is. net; leather, 2s. 6d. net. Forming Vol. 1 in Home University Library; for list, see p. 34.

IMMS (A. D.), B.Sc. (Lond.). Anurida. With 7 Plates. 45. net. See Liverpool Marine Biology Memoirs, p. 37.

ISGROVE (ANNIE), M.Sc. Eledone. With ro Plates. 4s. 6d. net. See Liverpool Marine Biology Memoirs, p. 37.

JACKS (L. P.), Editor of the Hibbert Journal. Mad Shepherds, and Other Human Studies. With a frontispiece drawing by Leslie Brooke. Crown 8vo, cloth. 4s. 6d. net.

Among the Idolmakers. Crown 8vo, cloth. 5s. net.

The Alchemy of Thought, and Other Essays. Demy 8vo, cloth. Ios. 6d. net.

JEREMIAS (Prof. ALFRED). The Old Testament in the Light of the Ancient East. The Translation is edited by Professor C. H. W. Johns of Cambridge. With a large number of Illustrations. In two volumes, demy $8 v 0$, at 25 s. net. See Theological Translation Library, New Series, p. 39.

JOHNSTON (Sir H. H.), D.Sc. The Opening-up of Africa. (With Maps.) F'cap. 8vo, cloth, Is. net; leather 2s. 6d. net. Forming Vol. 12 in the Home University Library; for list, see p. 35 . Views and Reviews. Essays on Racial, Political, and Colonial Questions. Crown 8vo, cloth. 3s. 6d. net.

JOHNSTONE (J.). British Fisheries : Their Administration and their Problems. A short account of the Origin and Growth of British Sea Fishery Authorities and Regulations. ros. 6d. net.

Cardium. With 7 Plates. Price 2s. 6d. net. See Liverpool Marine Biology Memoirs, p. 36.

JONES. The Freezing Point, Boiling Point, and Conductivity Methods. 12 mo. Pages vii +64 . I4 Illustrations. 3s. net.

JONES (J. T. SHARE-). Surgical Anatomy of the Horse. To be completed in 4 Parts. With above Ioo Illustrations, a number being in colour. Part I. Head and Neck. Part II. Fore Limb. Part III. Hind Limb. Price per part, 15s. net, sewed; cloth, 16s. 6d. net.

Life-Size Models, Illustrating the Superficial Anatomy of the Limbs of the Horse. Price per set of four models, $\mathcal{E}_{21}$; or separately-Fore Limb, Inner and Outer Aspects, $\mathcal{E}_{6,}$ 16s. 6d.

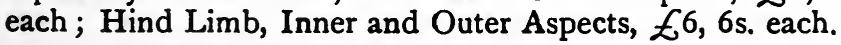


JONES (Rev. R. CROMPTON). Hymns of Duty and Faith. Selected and Arranged. 247 pp. F'cap. 8vo, cloth. 2nd Edition. 3s. 6d.

Chants, Psalms, and Canticles. Selected and Pointed for Chanting. $18 \mathrm{mo}$, cloth. Is. $6 \mathrm{~d}$.

Anthems. With Indexes and References to the Music. 18mo, cloth. Is. 3 d.

The Chants and Anthems. Together in I vol. Cloth. 2s.

A Book of Prayer. In Thirty Orders of Worship, with Additional Prayers and Thanksgivings. I8mo, cloth. 2s. 6d. With Chants, in 1 vol. $18 \mathrm{mo}$, cloth. $3 \mathrm{~s}$.

JONES (Rev. W. TUDOR), Ph.D. An Interpretation of Rudolf Eucken's Philosophy. Crown 8vo. 5s. net.

JORDAN (HUMFREY, R.), B.A. Blaise Pascal. A Study in Religious Psychology. Crown 8vo, cloth. 4s. 6d. net.

JOURNAL OF THE LINNEAN SOCIETY. Botany. At various prices. Index to Journal (Botany), 20s. Zoology. At various prices. General Index to the first 20 vols. of the Journal (Zoology) and the Zoological portion of the Proceedings, 20 .

JOURNAL OF THE QUEKETT MICROSCOPICAL CLUB. Nos. I-26, Is. net; Nos. 27-3 I, 2s. 6d. net. 1893, No. 32, and following Nos., half-yearly, 3s. 6d. net.

JOURNAL OF THE ROYAL MICROSCOPICAL SOCIETY, containing its Transactions and Proceedings, with other Microscopical information. Bi-monthly. Previous to 1893 at various prices; after that date bi-monthly, each 6s. net.

KAPP (GISBERT), D. Eng., M.I.E.E., M.I.C.E. Electricity. The Author is Professor of Electrical Engineering in the University of Birmingham. (Illustrated.) F'cap. 8vo, cloth, 1s. net ; leather, 2s. 6d. net. Forming Vol. $5^{8}$ in the Home University Library; see p. 36.

KAUFFMAN (RUTH and R. W.). The Latter Day Saints : A Study of the Mormons in the Light of Economic Conditions. Medium 8vo, cloth. Ios. 6d. net.

KAUTZSCH (E.), Professor at Halle. An Outline of the History of the Literature of the Old Testament. With Chronological Tables for the History of the Israelites, and other Aids to the Explanation of the Old Testament. Reprinted from the "Supplement to the Translation of the Old Testament." Edited by the Author. Translated by John Taylor, D. Litt., M.A., etc. Demy 8vo, cloth. 6s. 6d.

KEIM'S History of Jesus of Nazara: Considered in its connection with the National Life of Israel, and related in detail. Translated from the German by Arthur Ransom and the Rev. E. M. Geldart. In 6 vols. Demy 8vo, cloth. 6s. each. See Theological Translation Fund Library, p. 39.

KEITH (A.), M.D., LL.D. The Human Body. The Author is Conservator of Museum and Hunterian Professor, Royal College of Surgeons. (Illustrated.) F'cap. 8vo, cloth, Is. net ; leather 2s. 6d. net. Forming Vol. 57, Home University Library ; for list, see p. $3^{6}$. 
RENNEDY (Rev. JAS.). Introduction to Biblical Hebrew, presenting Graduated Instruction in the Language of the Old Testament. 8vo, cloth. I2S.

Studies in Hebrew Synonyms. Demy 8vo, cloth. $5 \mathrm{~s}$.

KER (Prof. W. P.), M.A. English Literature: Mediæval. F'cap. 8 vo, cloth, rs. net; leather, 2s. 6d. net. Forming Vol. 43 in the Home University Library ; for list, see p. 35.

KIEPERT'S Wall-Maps of the Ancient World-

Wall-Map of Ancient Italy. Italia antiqua. For the study of Livy, Sallust, Cicero, Dionysius, etc. Scale I : 800,000. Mounted on rollers, varnished. 20 s.

General Wall-Map of the Old World. Tabula orbis terrarum antiqui ad illustrandum potissimum antiquissimi ævi usque ad Alexandrum M. historiam. For the study of ancient history, especially the history of the Oriental peoples: the Indians, Medes, Persians, Babylonians, Assyrians, Egyptians, Phœnicians, etc. Scale I : 5,400,000. Mounted on rollers, varnished. 20 .

General Wall-Map of the Roman Empire. Imperii Romani tabula geographica. For the study of the development of the Roman Empire. Scale I : 300,000. Mounted on rollers, varnished. 245 .

Wall-Map of Ancient Latium. Latii Veteris et finitimarum regionum tabula. For the study of Livy, Dionysius, etc. Scale I : 125,000. With supplement: Environs of Rome. Scale I : 25,000. Mounted on rollers, varnished. I8s.

Wall-Map of Ancient Greece. Græciæ Antiquæ tabula. For the study of Herodotus, Thucydides, Xenophon, Strabo, Cornelius Nepos, etc. Scale I : 500,000. Mounted on rollers, varnished. 24s.

Wall-Map of the Empires of the Persians and of Alexander the Great. Imperia Persarum et Macedonum. For the study of Herodotus, Xenophon, Justinian, Arian, Curtius. Scale I : 300,000. Mounted on rollers and varnished. 20 .

Wall-Map of Gaul, with Portions of Ancient Britain and Ancient Germany. Galliæ Cisalpinæ et Transalpinæ cum partibus Britannæ et Germaniæ tabula. For the study of Cæsar, Justinian, Livy, Tacitus, etc. Scale I : $1,000,000$. Mounted on rollers and varnished. $24 \mathrm{~s}$.

Wall-Map of Ancient Asia Minor. Asiæ Minoris Antiquæ tabula. For the study of Herodotus, Xenophon, Justinian, Arian, Curtius, etc. Scale I : 800,000. Mounted on rollers and varnished. 20 s.

New Atlas Antiquus. Twelve Maps of the Ancient World, for Schools and Colleges. Third hundred thousand. I 2 th Edition, with a complete Geographical Index. Folio, boards. 6s. Strongly bound in cloth. 7s. 6d.

KING, THE, TO HIS PEOPLE. Being the Speeches and Messages of His Majesty George V. as Prince and Sovereign. Published by permission. Square 8vo, art canvas. $5 \mathrm{~s}$. net. 
KITTEL (Dr RUDOLF), of Breslau. A History of the Hebrews. In 2 vols. 8vo, cloth. Each volume, 1os. 6 d. Forming Vols. 3 and 6 of the Theological Translation Library, New Series; for list, see p. 38 . The Scientific Study of the Old Testament: Its Principal Results, and their Bearing upon Religious Instruction. Illustrated. 5s. net. Forming Vol. 32 in Crown Theological Library; for list, see p. 33. KUENEN (Dr A.), of Leiden. The Religion of Israel to the Fall of the Jewish State. Translated from the Dutch by A. H. May. 3 vols. 8vo, cloth. 18s. See Theological Translation Fund Library, p. 39.

KYRIAKIDES (A.). Modern Greek-English Dictionary. With a Cypriote Vocabulary. 2nd Edition, revised throughout. Medium 8vo. 920 pages. Cloth. I 5s. net.

A Modern Greek-English and English-Modern Greek Pocket Dictionary. In 2 vols., about $65^{\circ}$ pages each. 7 s. net each volume. LAKE (KIRSOPP). The Historical Evidence for the Resurrection of Jesus Christ. The Author is Professor of New Testament Exegesis in the University of Leiden, Holland. Crown 8vo, cloth. 4s. 6d. net. Forming Vol. $2 \mathrm{I}$ in the Crown Theological Library; see p. 32.

LANDOLT (Dr HANS). The Optical Rotating Power of Organic Substances and its Practical Applications. 8vo. Pages xxi+751. 83 Illustrations. 3 Is. 6d. net.

LAURIE (Prof. SIMON). Ethica : or, The Ethics of Reason. By Scotus Novanticus. 2nd Edition. 8vo, cloth. 6s.

Metaphysica Nova et Vetusta : A Return to Dualism. 2nd Edition. Crown 8vo, cloth. 6s.

LEA (HENRY CHARLES), LL.D. History of Sacerdotal Celibacy in the Christian Church. 3rd Edition. Thoroughly Revised and Reset. 2 vols. Medium 8vo, cloth. 2 Is. net.

LEAVENWORTH (Prof. W. S.), M.Sc. Inorganic Qualitative Chemical Analysis for Advanced Schools and Colleges. 8vo. Pages vi + r 54. 6s. 6d. net.

LEBLANC (Dr MAX). The Production of Chromium and its Compounds by the Aid of the Electric Current. Demy 8vo, cloth. 5s. net.

LEIPOLDT (C. LOUIS), F.R.C.S. Eng. Common-sense Dietetics. Strongly bound in Cloth. Crown 8vo. 2s. 6d. net.

LETHABY (Prof. W. R.). Architecture. Over 40 Illustrations. F'cap. 8vo, cloth, Is. net; leather, 2s. 6d. net. Forming Vol. 39 in the Home University Library ; for list, see page 35.

LEWIS (AGNES SMITH), Edited by. Old Syriac Gospels, or Evangelion Da-Mepharreshe. This is the Text of the Sinai Palimpsest, including the latest additions and emendations, with the variants of the Curetonian Text, corroborations from many other MSS., and a list of quotations from ancient authors. With 4 facsimiles. Quarto, bound half-leather. $25 \mathrm{~s}$. net. 
LLURIA (Dr ENRIQUE). Super-Organic Evolution. Nature and the Social Problem. With a Preface by Dr D. Santiago Ramon y Cajal. Large Crown 8vo. Illustrated. 7s. 6d. net.

LOBSTEIN (PAUL). The Virgin Birth of Christ: An Historical and Critical Essay. The Author is Professor of Dogmatics in the University of Strassburg. Translated by Victor Leuliette, A.K.C., B.-ès-L., Paris. Edited, with an Introduction, by Rev. W. D. Morrison, LL.D. Crown 8vo. 2s. 6d. net. Forming Vol. 2 in the Crown Theological Library; for list, see p. $3 \mathbf{I}$.

LODGE (Sir O.). Life and Matter : An Exposition of Part of the Philosophy of Science, with Special References to the Influence of Professor Haeckel. Second Edition, with an Appendix of Definitions and Explanations. Crown 8vo, cloth. 2s. 6d. net. Popular Edition. Paper Cover. 6d. net.

School Teaching and School Reform. A Course of Four Lectures on School Curricula and Methods, delivered to Secondary Teachers and Teachers in Training at Birmingham. 3 s.

LONDON LIBRARY (St James's Square), Catalogue of. xiv + 1626 pages. 4to, bound in buckram. 42S. net. Supplements I.-VIII., bound in buckram, $5 \mathrm{~s}$. each.

Subject Index. 4to, bound in buckram. xxxviii $+\mathbf{2} 256$ pages. 3 Is. 6d. net.

LONG (J. H.). A Text-book of Urine Analysis. Small 8vo. Pages $v+249$. 3I Illustrations. 6s. 6d. net.

LYALL (Sir C. J.), M.A., K.C.I.E. Ancient Arabian Poetry, chiefly Præ-Islamic. Translations, with an Introduction and Notes. F'cap. 4to, cloth. ros. 6d.

MACAN (R. W.). The Resurrection of Jesus Christ. An Essay in Three Chapters. 8vo, cloth. $5 \mathrm{~s}$.

MACAULAY (THOMAS BABINGTON). The Lays of Ancient Rome. With 8 Illustrations faithfully reproduced in colours, and a number in black-and-white, from original drawings by Norman Ault. Small 4to, cloth. 6s. net.

MACCOLL (HUGH). Man's Origin, Destiny, and Duty. Crown 8vo, cloth. 4s. 6d. net.

MACDONALD (J. RAMSAY), M.P. The Socialist Movement. F'cap. 8vo, cloth, rs. net; leather, 2s. 6d. net. Vol. ro in the Home University Library ; for list, see p. 35.

McDOUGALL (Prof. W.), F.R.S., M.B. Psychology: the Study of Behaviour. F'cap. 8vo, cloth, Is. net; leather, 2s. 6d. net. Vol. 49 in the Home University Library; for list, see p. 36.

MACFIE (RONALD C.), M.A., M.B. Science, Matter, and Immortality. Crown 8vo, cloth. 5s. net.

MACGREGOR (Prof. D. H.), M.A. The Evolution of Industry. F'cap. 8vo, cloth, Is. net; leather, 2s. 6d. net. Vol. 24 in the Home University Library; for list, see p. 35. 
McKENDRICK (Prof. J. G.), M.D. The Principles of Physiolog) F'cap. 8vo, cloth, Is. net; leather, 2s. 6d. net. Vol. 44 in th Home University Library; for list, see p. 35.

MACKENZIE (W. LESLIE), M.D. Health and Disease F'cap. 8vo, cloth, Is. net ; leather, 2s. 6d. net. Forming Vol. I in the Home University Library ; for list, see p. 35.

MAIR (G. H.), M.A. English Literature: Modern. F'cap. 8vc cloth, Is. net ; leather, 2s. 6d. net. Forming Vol. 27 in the Hom University Library; for list, see p. 35 .

MARETT (R. R.), M.A., of Oxford. Anthropology. F'cap. 8vc cloth, Is. net; leather, 2S. 6d. net. Forming Vol. 41 in th Home University Library; for list, see p. 35.

MARGOLIOUTH (Prof. D. S.), M.A., D.Litt. Mohammedanism F'cap. 8vo, cloth, is. net ; leather, 2s. 6d. net. Forming Vol. I in the Home University Library ; for list, see p. 35.

MARKHAM (Sir CLEMENTS), K.C.B. Vocabularies of th General Language of the Incas of Peru. Crown 8vo, cloth 7s. 6d. net.

MARRINER (GEORGE R.), F.R.M.S. The Kea : a New Zealan Problem. With Illustrations. Demy 8vo, cloth. 7s. 6d. net.

MARTI (KARL). The Religion of the Old Testament : Its Plac among the Religions of the Nearer East. The Author is Professo of Old Testament Exegesis, Bern. Crown 8vo, cloth, 4s. net Forming Vol. 19 in the Crown Theological Library ; for list, see p. 32 MARTINEAU (Rev. Dr JAMES). The Relation betweer Ethics and Religion. An Address. 8vo, sewed. Is.

Modern Materialism : Its Attitude towards Theology. A Critiqu and Defence. 8vo, sewed. 2s. 6d.

MASEFIELD (JOHN). Shakespeare. F'cap. 8vo, cloth, Is. net leather, 2s. 6d. net. Forming Vol. 2 in the Home Universit Library ; for list, see p. 34 .

MASON (W. P.). Notes on Qualitative Analysis. Sm. I 2 mo 56 pp. 3s. 6 d. net.

MEADE (RICHARD K.), B.Sc. Chemist's Pocket Manual I6mo. Leather. Pocket Edition. Second Edition. I2s. 6d. net Portland Cement: Its Composition, Raw Materials, Manufacture Testing, and Analysis. Second Edition. With I70 Illustrations 2os. net.

MEEK (ALBERT STUART). A Naturalist in Oceania. With Introduction by the Hon. Walter Rothschild. Edited by Frank Fox. Medium 8vo. With a number of Illustrations. net. MELVILLE (HELEN and LEWIS). The Seasons. An Anthology in Prose and Verse. Forming an attractive volume, bound in art linen. 3s. 6d. net.

MERCER (Rt. Rev. J. EDWARD), D.D. The Soul of Progress. Being the Moorhouse Lectures for 1907. Crown 8vo, cloth. 6s. 
MERCIER (Dr C. A.), F.R.C.P. Crime and Insanity. F'cap. 8 vo, cloth, 1s. net; leather, 2s. 6d. net. Forming Vol. 22 in the Home University Library; for list, see p. 35.

MBREDITH (LEWIS B.). Rock Gardens. How to Make and Maintain them. With an Introduction by F. W. Moore, A.L.S., and an Alphabetical List of Plants suitable for the Rock Garden, with Notes on the aspect and soil they require. Demy 8vo, with Plates. 7s. 6d. net.

MERIMEE (PROSPER). Le Coup de Pistolet, etc. 2s. 6d See Army Series of French and German Novels, p. 3 I.

MILINDAPAÑHO, THE. Being Dialogues between King Milinda and the Buddhist Sage Nāgasena. The Pali Text, edited by V. Trenckner. Crown 8vo, sewed. 2 is.

MITCHELL (Rev. A. F.). How to Teach the Bible. 2nd Edition, thoroughly revised and reset. Crown 8vo, cloth. 2s. 6d. net.

MOISSON (HENRI). The Electric Furnace. 8vo. Pages $x+305$. 4I Illustrations. Ios. 6d. net.

MONTEFIORE (C. G.). Origin and Growth of Religion as Illustrated by the Religion of the Ancient Hebrews. The Hibbert Lectures, 1892. 2nd Edition. 8vo, cloth. 10s. 6d. Cheap Edition, 3s. 6d.

MOORE (G. E.), M.A. Ethics. The Author is Lecturer in Moral Science in Cambridge University. F'cap. 8vo, cloth, Is. net; leather, 2s. 6d. net. Forming Vol. 54 in the Home University Library; for list, see p. 36.

MÜNSTERBERG (Prof. HUGO), of Harvard. The Americans. Translated by Edwin B. Holt, Ph.D., Instructor at Harvard University. Royal 8vo, cloth. I 2s. 6d. net.

MURRAY (Prof. GILBERT), D.Litt., LL.D., F.B.A., Editor of the Home University Library. For list, see p. 34 .

MYRES (J. L.), M.A., F.S.A. The Dawn of History. The Author is Wrkeham Professor of Ancient History, Oxford. F'cap. 8vo, cloth, is. net; leather, 2s. 6d. net. Forming Vol. 29 in the Home University Library ; for list, see p. 35 .

NAVILLE (EDOUARD), Ph.D., Litt. D. 'The Old Egyptian Faith. Translated by Colin Campbell, M.A., D.D. Illustrated. 4s. 6 d. net. Vol. 30 in Crown Theological Library ; for list, see p. 33.

NESTLE (Prof. EBERHARD), of Maulbronn. An Introduction to the Textual Criticism of the Greek New Testament. Translated from the Second Edition, with Corrections and Additions by the Author, by William Edie, B.D., and edited, with a Preface, by Allan Menzies, D.D., Professor of Divinity and Biblical Criticism in the University of St Andrews. With eleven reproductions of Texts. Demy 8vo, ros. 6d. ; half-leather, r2s. 6d. Forming Vol. 13 in the Theological Translation Library, New Series, p. 38 .

VEWBIGIN (Dr MARION). Modern Geography. Illustrated. F'cap. 8vo, cloth, Is. net; leather, 2s. 6d. net. Forming Vol. 7 in the Home University Library; for list, see p. 34. 
NEW HEBREW SCHOOL OF POETS OF THI SPANISH-ARABIAN EPOCH. Selected Texts wit Introduction, Notes, and Dictionary. Edited by $\mathrm{H}$. Brodey, $\mathrm{Ph} . \mathrm{D}$ Rabbi in Lachod (Bohemia), and K. Albrecht, Ph.D., Professor i Oldenburg (Grand Duchy). English Translation of the Intro duction, etc., by Mrs Karl Albrecht. Cloth. 7s. 6d. net.

NIBELUNGENLIED. "The Fall of the Nibelungens," othe wise "The Book of Kriemhild." An English Translation b. W. N. Lettsom. 5th Edition. 8vo, cloth. 5s.

NIKAIDO (Y.), B.Sc., M.A. Beet-Sugar Making and its Chemicz Control. With a number of valuable Tables and Illustration: Demy 8vo, cloth. I 2. 6d. net.

NISSENSON. The Arrangements of Electrolytic Laboratorie: Demy 8vo. 52 Illustrations. 5s. net.

NOLDEKE (Prof. THEODOR). Compendious Syriac Gramma: With a Table of Characters by Julius Euting. Translated (wit the sanction of the Author) from the Second and Improved Germa Edition by Rev. James A. Crichton, D.D. Royal 8vo. 18s. net - Delectus Veterum Carminum Arabicorum Glossarium Confec: A Muller. Crown 8vo, cloth. 7s. 6d.

NOYES (ARTHUR A.), Ph.D. Organic Chemistry for th Laboratory. Small r 2mo. Pages xii +257.22 Illustrations 6s. 6d. net.

- and SAMUEL P. MULLIKEN, Ph.D. Laborator Experiments on Class Reactions and Identification of Organi Substances. 8vo. 8I pp. 2s. net.

O'GRADY (STANDISH H.). Silva Gadelica (I.-XXXI.). Collection of Tales in Irish, with Extracts illustrating Person and Places. Edited from MSS. and Translated. 2 vols. royal 8vc cloth. 42s. Or separately, Vol. I, Irish Text; and Vol. 2 Translation and Notes. Each Vol. 2 Is.

OORDT (J. F. VAN), B.A. Cape Dutch. Phrases and Dialogues with Translations, preceded by short Grammatical Notes. Crow: $8 \mathrm{vo}$, cloth. 2s. 6d. net.

OTTO (Prof. RUDOLF). Naturalism and Religion. Translated $b$ J. Arthur Thomson, Professor of Natural History in the Universit of Aberdeen, and Margaret R. Thomson. Edited with an Intro duction by Rev. W. D. Morrison, LL.D. Crown 8vo. 5s. nel Forming Vol. I 7 in the Crown Theological Library; see p. 32.

PARKER (PERCY L.), Editor of "Public Opinion." Characte and Life. A Symposium. Containing contributions by $D$ Alfred Russel Wallace, John A. Hobson, Walter Crane, Harol Begbie, and the late Dr Emil Reich. Crown 8vo, cloth. 3s. 6d. net

PAXSON (Prof. F. L.). The American Civil War. With Maps F'cap. 8vo, cloth, is. net; leather, 2s. 6d. net. Forming Vol. 4 in the Home University Library ; for list, see p. 35.

PEARSON (JOSEPH), M.Sc. Cancer. With 13 Plates. 6s. $6 \dot{c}$ net. See Liverpool Marine Biology Memoirs, p. 37. 
PEDDIE (R. A.). Printing at Brescia in the Fifteenth Century. A List of the Issues. $5 \mathrm{~s}$. net.

PERCIVAL (G. H.). The Incarnate Purpose. Essays on the Spiritual Unity of Life. Crown 8vo, cloth. 2s. 6d. net.

PEROWNE (J. T. W.), M.A., Editor of the Army Series of French and German Novels. For list, see p. $3 \mathrm{I}$.

PERRIS (G. H.). A Short History of War and Peace. F'cap. 8vo, cloth, Is. net ; leather, 2s. 6d. net. Forming Vol. 4 in the Home University Library ; for list, see p. 34 .

PETERS (JOHN P.), D.D. Early Hebrew Story. A Study of the Origin, the Value, and the Historical Background of the Legends of Israel. Crown 8vo, cloth. 4s. 6d. net. Forming Vol. 7 in the Crown Theological Library; for list, see p. 32.

PETIT (ROBERT). How to Build an Aeroplane. Trans. from the French, with additional matter, by T. O'B. Hubbard \& J. H. Ledeboer. With nearly Ioo Illustrations. Demy 8vo, cloth. 2s. 6d. net.

PFANHAUSER (Dr W.). Production of Metallic Objects Electrolytically. 5s. net.

IPFLEIDERER (Dr O.). Lectures on the Influence of the Apostle Paul on the Development of Christianity. Translated by Rev. J. Frederick Smith. Being the Hibbert Lectures for 1885 . Library Edition. Demy 8vo, cloth. ros. 6d. Cheap Edition, cloth. 3s. 6d. See The Hibbert Lectures, p. 34.

Paulinism: A Contribution to the History of Primitive Christianity. 2 vols. Demy 8vo, cloth. I 2s. See Theological Translation Library, Old Series, p. 40.

Philosophy of Religion on the Basis of its History. In 4 vols. Demy 8vo, cloth. 24s. SeeTheological Translation Library, Old Series, p. 40. [Vol. 2 quite out of print.]

Primitive Christianity: Its Writings and Teachings in their Historical Connections. 4 vols. ros. 6d. net each. See Theological Translation Library, New Series, p. 38.

The Early Christian Conception of Christ: Its Significance and Value in the History of Religion. 3s. net. See Crown Theological Library, p. $3^{2}$.

IPHILLIPPS (V.), B.A. A Short Sketch of German Literature, for Schools. 2nd Edition, revised. Pott 8vo, cloth. Is.

PHILLIPS (FRANCIS C.). Methods for the Analysis of Ores, Pig Iron, and Steel. 2nd Edition. 8vo. Pages viii +170 . 3 Illustrations. 4s. 6 d. net.

PICTON (J. ALLANSON), M.A. Lond. Man and the Bible. A Review of the Place of the Bible in Human History. Demy 8vo, cloth. 6s. net.

PIDDINGTON (HENRY). The Sailors' Horn-Book for the Law of Storms. Being a Practical Exposition of the Theory of the Law of Storms, and its uses to Mariners of all Classes in all Parts of the World. Shown by transparent Storm Cards and useful Lessons. 7 th Edition. Demy 8vo, cloth. Ios. 6d. 
PLATTS (J. T.), Hon. M.A. (Oxon.). A Grammar of the Persiar Language. Part I. Accidence. Broad crown 8vo. Ios. 6d.

POLLARD (Prof. A. F.), M.A. The History of England: A Study in Political Evolution. With a Chronological Table. F'cap $8 \mathrm{vo}$, cloth, Is. net; leather, 2s. 6d. net. Forming Vol. 33 in the Home University Library; for list, see p. 35.

PRAY (Dr). Astigmatic Letters. Printed on Millboard, size 22 by I 4 inches. Is.

PROCEEDINGS OF INTERNATIONAL CONFER ENCE under the Auspices of the American Society for Judicial Settlement of International Disputes, held at Washington, Dec. I910. In I vol., sewed. 4S. net.

PROCEEDINGS OF THE ARISTOTELIAN SOCIETY FOR THE SYSTEMATIC STUDY OF PHILOSOPHY. Old Series-Odd Numbers at various prices. New Series (yearly volumes bound in buckram)-Vols. I.-XI. ready, Ics. 6d. each net.

PROCEEDINGS OF THE OPTICAL CONVENTION, No. I, 1905. Crown 4to, cloth. ros. net.

PROCEEDINGS AND PAPERS OF THE FIFTH INTERNATIONAL CONGRESS OF FREE CHRISTIANITY. Held at Berlin, igro. Edited by C. W. Wendte, D.D., and V. D. Davis, B.A. Medium 8vo, cloth. 9s. 6d. net. Sewed, 8s. 6d. net.

PUNNETT (R. C.), B.A. Lineus. With 4 Plates. 2s. net. See Liverpool Marine Biology Memoirs, p. 36.

RADER (A.). L'Arbitrage International chez les Hellènes. 4to, sewed. I os. net. Being Vol. I. of Publications de l'Institut Nobel Norvégien. RAY (Prof. P. C.). A History of Hindu Chemistry from the Earliest Times to the Middle of the Sixteenth Century A.D. With Sanskrit Texts, Variants, Translation, and Illustrations. Vol. I. 2nd Edition. Revised and Enlarged. Crown 8vo, ros. 6d. net. Vol. II. Cloth. Ios. 6d. net.

REICH (Dr EMIL), Contributor to "Character and Life." See p. 4.

RENAN (E.). On the Influence of the Institutions, Thought, and Culture of Rome on Christianity and the Development of the Catholic Church. Translated by the Rev. Charles Beard. Being the Hibbert Lectures, 1880. 8vo, cloth. Ios. 6d. Cheap Edition (3rd Edition), 3s. 6d.

RENOUF (P. LE PAGE). On the Religion of Ancient Egypt. Hibbert Lectures, 1879. 3rd Edition. 8vo, cloth. Ios. 6d. Cheap Edition, 3s. 6d.

REVILLE (Dr A.). On the Native Religions of Mexico and Peru. Translated by the Rev. P. H. Wicksteed. Hibbert Lectures, 1884 . 8vo, cloth. Ios. 6d. Cheap Edition, 3s. 6d.

Prolegomena of the History of Religions. With an Introduction by Prof. F. Max Müller. 8vo, cloth. 6s. See Theological Translation Library, Old Series, p. 40. 
REVILLE (Prof. JEAN). Liberal Christianity: Its Origin, Nature, and Mission. Translated and Edited by Victor Leuliette, A.K.C., B.-ès-L. Crown 8vo, cloth. 3s. 6d. net. Forming Vol. 4 in the Crown Theological Library; for list, see p. $3 \mathrm{I}$.

RHYS (Prof. J.). On the Origin and Growth of Religion as Illus: trated by Celtic Heathendom. Hibbert Lectures, I886. 8vo, cloth. ros. 6d. Cheap Edition, 3s. 6d.

RIEDEL (Prof. W.) and W. E. CRUM. The Canons of Athanasius of Alexandria, in Arabic, Ethiopic, and Coptic. 2 Is. net. See Text and Translation Society, p. 37.

RIX (HERBERT). Tent and Testament. A Camping Tour in Palestine, with some Notes on Scripture Sites. With 6I Illustrations, Frontispiece, and Maps. Demy 8vo, cloth. 8s. 6d. net.

ROGET (F. F.). An Introduction to Old French. History, Grammar, Chrestomathy, and Glossary. 2nd Edition. Crown 8vo, cloth. 6s. First Steps in French History, Literature, and Philology. For Candidates for the Scotch Leaving Certificate Examinations, the various Universities Local Examinations, and the Army Examinations. 4th Edition. Crown 8vo, cloth. 5s.

RUFFINI (FRANCESCO). Religious Liberty. The Author is Ordinary Professor at the Royal University of Turin. With an Introduction by Prof. J. B. Bury of Cambridge. Demy 8vo. I $2 \mathrm{s.} 6 \mathrm{~d}$. net. Forming Vol. 32 in the Theological Translation Library; see p. 39.

RUSSELL (Hon. BERTRAND), F.R.S. The Problems of Philosophy. F'cap. 8vo, cloth, Is. net; leather, 2s. 6d. net. Forming Vol. 40 in Home University Library; for list, see p. 35.

SABATIER (Late AUGUSTE). The Doctrine of the Atonement and its Historical Evolution; and Religion and Modern Culture. Translated by Victor Leuliette, A.K.C., B.-ès-L. Cr. 8vo. 45. net. Forming Vol. 9 in the Crown Theological Library; see p. 32. The Religions of Authority and the Religion of the Spirit. New impression. Demy 8vo, cloth. Ios. 6d. See Theological Translation Library, New Series, p. 38.

SADI. The Gulistan (Rose Garden) of Shaik Sadi of Shiraz. A new Edition of the Persian Text, with a Vocabulary, by F. Johnson. Square royal 8vo, cloth. I 5 s.

SADLER (Rev. Dr). Prayers for Christian Worship. Crown 8vo, cloth. 3s. 6d.

Closet Prayers, Original and Compiled. I8mo, cloth. Is. 6d.

SADLER (GILBERT), M.A., LL.B. A Short Introduction to the Bible. Crown 8vo, cloth. 2s. 6d. net.

SAGAS OF OLAF TRYGGVASON AND OF HAROLD THE TYRANT. A new translation, well illustrated with drawings by Erik Werenskiold, Christian Krogh, and others of the best Norwegian artists. In small 4 to, printed on specially mouldmade paper, comprising above 200 pages, bound with linen back and paper sides, done up in box. I $2 \mathrm{~s}$. $6 \mathrm{~d}$. net. 
SALEEBY (C. W.), M.D., F.R.S. Individualism and Collectivism. Crown 8vo, cloth. 2s.

SAUNDERS (T. BAILEY). Professor Harnack and his Oxford Critics. Crown 8vo, cloth. is. 6d. net.

SAYCE (Prof. A. H.). On the Origin and Growth of Religion as illustrated by the Religion of the Ancient Babylonians. 5th Edition. Hibbert Lectures, I 887. 8vo, cloth. Ios. 6d. Cheap Edition, 3s. 6d. SCHRADER (Prof E.). The Cuneiform Inscriptions and the Old Testament. Translated from the Second Enlarged Edition, with Additions by the Author, and an Introduction by the Rev. Owen C. Whitehouse, M.A. 2 vols. With a Map. 8vo, cloth. I2s. See Theological Translation Library, Old Series, p. 40.

SCHREBER (D. G. M.). Medical Indoor Gymnastics, or a System of Hygienic Exercises for Home Use, to be practised anywhere, without apparatus or assistance, by young and old of either sex, for the preservation of health and general activity. Revised and Supplemented by Rudolf Graefe, M.D. With a large plate and 45 illustrations in the text. Royal 8vo, cloth. 2s. 6 d. net.

SCHROEN (L.). Seven-Figure Logarithms of Numbers from $\mathbf{t}$ to 108,000, and of Sines, Cosines, Tangents, Cotangents to every 10 Seconds of the Quadrant. With a Table of Proportional Parts. By Dr Ludwig Schroen, Director of the Observatory of Jena, etc., etc. 5th Edition, corrected and stereotyped. With a description of the Tables by A. De Morgan, Professor of Mathematics in University College, London. Imp. 8vo, cloth, printed on light green paper. $9 \mathrm{~s}$.

SCHUBERT (HANS VON). History of the Church. Translated from the Second German Edition. By arrangement with the Author, an Additional Chapter has been added on "Religious Movements in England in the Nineteenth Century," by Miss Alice Gardner, Lecturer and Associate of Newnham College, Cambridge. Demy 8vo, cloth. Ios. 6d. See Theological Translation Library, New Series, p. 39.

SCHURMAN (J. GOULD). Kantian Ethics and the Ethics of Evolution. 8vo, cloth. 5s.

The Ethical Import of Darwinism. Crown 8vo, cloth. 5 s.

SCHUSTER (ERNEST J.). The Wife in Ancient and Modern Times. Crown 8vo, cloth. 4s. 6d. net.

SCOTT (ANDREW). Lepeophtheirus and Lernea. With 5 Plates. 2s. net. See Liverpool Marine Biology Committee Memoirs on Typical British Marine Plants and Animals, p. 36.

SCOTT (Dr D. H.), M.A., F.R.S. The Evolution of Plants. Fully illustrated. F"cap. 8vo, cloth, Is. net; leather, 2s. 6d. net. Forming Vol. 9 in the Home University Library; for list, see p. 34 . SCOTT (E. F.), M.A. The Apologetic of the New Testament. Cr. 8vo, cloth. 4s. 6d. net. See Crown Theological Library, p. 32.

I4 Henrietta Street, Covent Garden, London, W.C. 
SEEBERG (Prof. R.), of Berlin. The Fundamental Truths of the Christian Religion. Sixteen Lectures delivered before the Students of all Faculties in the University of Berlin. Crown 8vo. 350 pp. 4S. 6d. net. See Crown Theological Library, p. 32.

SEGER (HERMAN AUGUST), Collected Writings of. Papers on Manufacture of Pottery. 2 vols. Large 8vo. £3, 3s. net per set.

SELBIE (Principal W. B.), M.A. Nonconformity: Its Origin and Progress. F'cap. 8vo, cloth, Is. net; leather, 2s. 6d. net. Forming Vol. 50 in the Home University Library; for list, see p. $3^{6 .}$ SEVERUS (Patriarch of Antioch). The Sixth Book of the Select Letters of Severus, Patriarch of Antioch, in the Syriac Version of Athanasius of Nisibis. Edited and Translated by E. W. Brooks. Vol. I. (Text), Part I, and Vol. II. (Translation), Part I. 2 vols. 8vo, cloth. 42s. net. Vol. I. (Text), Part 2, and Vol. II. (Translation), Part 2. 2 vols. 8 vo, cloth. 42s. net. See Text and Translation Society, p. 37.

SHARPE (HENRY). Britain B.C.: As Described in Classical Writings. With an Inquiry into the positions of the Cassiterides and Thule, and an attempt to ascertain the ancient coast-line of Kent and East Sussex. With Maps. Crown 8vo, cloth. 5s. net. SHEARMAN (A. T.), M.A. The Development of Symbolic Logic. A Critical Historical Study of the Logical Calculus. Crown 8vo, cloth. 5s. net.

SICHEL (WALTER). Laurence Sterne. A Study. To which is added the Journal to Eliza, with portraits, facsimiles, autographs, etc. Demy 8vo, cloth. 8s. 6d. net.

SMITH (L. PEARSALL), M.A. The English Language. F'cap. 8 vo, cloth, Is. net; leather, 2s. 6d. net. Forming Vol. 45 in the Home University Library ; for list, see p. 35 .

SNELLEN'S OPHTHALMIC TEST TYPES. Best Types for the Determination of the Acuteness of Vision. I4th Edition, considerably augmented and improved. 8vo, sewed. 4s. Single Sheets: E T B, M O V, B D E, $ш ш \omega$, and Large Clock Sheet. 8d. each. Small Clock Sheet and R T V Z. 4d. each.

SNYDER (HARRY), B.Sc. Soils and Fertilisers. 2nd Edition. 8vo. Pages $x+294$. I Plate, 40 Illustrations. 6s. 6d. net.

SODDY (F.), M.A., F.R.S. Matter and Energy. F'cap. 8vo, cloth, Is. net; leather, 2s. 6d. net. Forming Vol. 46 in the Home University Library ; for list, see p. 35 .

SODEN (Prof. H. VON), D.D. The Books of the New Testament. Translated by the Rev. J. R. Wilkinson, and edited by Rev. W. D. Morrison, LL.D. Crown 8vo, cloth. 4s. 6d. net. See Crown Theological Library, p. 32.

SOLILOQUIES OF ST AUGUSTINE, THE. Translated into English by Rose Elizabeth Cleveland. With Notes and Introduction by the Translator. Small demy 8vo, cloth. 6s. net.

I4 Henrietta Street, Covent Garden, London, W.C. 
SOMERVILLE (Prof. W.), D.Sc. Agriculture. F'cap. 8vo, cloth, Is. net; leather, 2s. 6d. net. Forming Vol. 26 in the Home University Library ; for list, see p. 35.

SONNTAG (C. O.). A Pocket Flora of Edinburgh and the Surrounding District. A Collection and full Description of all Phanerogamic and the principal Cryptogamic Plants, classified after the Natural System, with an artificial Key and a Glossary of Botanical Terms. By the late C. O. Sonntag. F'cap. 8vo, limp cloth. 3s. 6d. net.

SORENSEN (S.), Ph.D., Compiled by. An Index to the Names in the Mahabharata. With short explanations. Royal 4to, in twelve parts, which are not sold separately, at $7 \mathrm{~s} .6 \mathrm{~d}$. per part net. Parts I. to VI. now ready.

SPEARS (J. R.). Master Mariners. F'cap. 8vo, cloth, rs. net; leather, 2s. 6d. net. Forming Vol. 55 in the Home University Library; for list, see p. 36.

SPENCER (HERBERT) A System of Synthetic PhilosophyVol. I. First Principles. With an Appendix and a Portrait. Finally revised. New Edition, large crown 8vo, cloth. 7s. 6d. Specially printed cheap edition, bound in cloth. 2 vols. of 240 pages each. Is. net per volume. Complete in one volume. 2s. net.

Vols. II. and III. The Principles of Biology. 6th Thousand. $8 \mathrm{vo}$, cloth. Revised and greatly enlarged. 2 vols. $18 \mathrm{~s}$. each.

Vols. IV. and V. The Principles of Psychology. 5th Thousand. 2 vols. 8 vo, cloth. $36 \mathrm{~s}$.

Vol. VI. The Principles of Sociology. Vol. I. Part I, The Data of Sociology; Part 2, The Inductions of Sociology; Part 3, Domestic

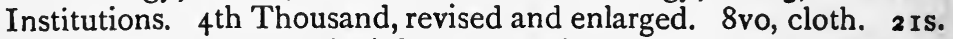

Vol. VII. The Principles of Sociology. Vol. II. Part 4, Ceremonial Institutions; Part 5, Political Institutions. 3rd Thousand. 8vo, cloth. $\mathrm{x} 8 \mathrm{~s}$.

Vol. VIII. The Principles of Sociology. Vol. III. Part 6, Ecclesiastical Institutions; Part 7, Professional Institutions ; Part 8, Industrial Institutions. 2nd Thousand. 8vo, cloth. $16 \mathrm{~s}$.

Vol. IX. The Principles of Ethics. Vol. I. Part x, The Data of Ethics; Part 2, The Inductions of Ethics; Part 3, The Ethics of Individual Life. 8vo, cloth. 155.

Vol. X. The Principles of Ethics. Vol. II. Part 4, Justice; Part 5, Negative Beneficence; Part 6, Positive Beneficence; Appendices. Demy 8vo, cloth. I 2s. 6d.

A Rejoinder to Professor Weismann. Sewed. 6d.

Data of Ethics. Reset uniform with popular edition of "First Principles." Sewed, 2s. 6d. net ; cloth, 3s. net.

Descriptive Sociology ; or, Groups of Sociological Facts. Compiled and abstracted by Professor D. Duncan of Madras, Dr Richard Scheppig, and James Collier. Folio, boards.

No. 1. English. 18s.

No. 2. Ancient American Races. x6s. 
SPENCER (HERBERT)-Descriptive Sociology-continued.

No. 3. Lowest Races, Negritto Races, Polynesians. I8s.

No. 4. African Races. I6s.

No. 5. Asiatic Races. I8s.

No. 6. American Races. I8s.

No. 7. Hebrews and Phœenicians. 2 Is.

No. 8. The French Civilisation. 3os.

No. 10. Greeks: Hellenic Era. By Rev. Dr J. P. Mahaffy, and Professor W. A. Goligher, Trinity College, Dublin. 2 Is.

No. I I. Chinese. Compiled and abstracted by E. T. C. Werner, H.M.'s Consular Service, China. 63s.

Education: Intellectual, Moral, and Physical. Popular Edition. Entirely reset. Crown 8vo, cloth. 2s. 6d. Cheap Edition, cloth, Is. net.

Essays: Scientific, Political, and Speculative. A new Edition, rearranged, with additional Essays. 3 vols. 8vo, cloth. (Each ros.) 3 os.

Facts and Comments. Demy 8vo, cloth. 6s.

Justice. Being Part 4 of the Principles of Ethics. 2nd Thousand. 8 vo, cloth. 6s.

Reasons for Dissenting from the Philosophy of M. Comte Sewed. 6d.

Social Statics. Abridged and revised, together with "The Man v. The State." 8vo, cloth. Ios.

The Man versus The State. I 4 th Thousand. Sewed. Is.

The Study of Sociology. Library Edition (2 Ist Thousand), with a Postscript. 8vo, cloth. Ios. 6d.

- Various Fragments. Uniform in Library binding. Demy 8vo, cloth. Enlarged Edition. 6s.

STATUTES, THE, OF THE APOSTLES. The hitherto unedited Ethiopic and Arabic Texts, with Translations of Ethiopic, Arabic, and Coptic Texts, by G. Horner, M.A.

STEPHEN (Rev. Canon REGINALD), M.A. Democracy and Character. Being the Moorhouse Lectures for I 908. Crown 8vo, cloth. 5s.

STERNE (LAURENCE). A Sentimental Journey through France and Italy. With I 2 Illustrations faithfully reproduced from water-colour drawings by Everard Hopkins. Ordinary Edition in crown 4 to, Ios. 6d. net. Edition de Luxe, limited to 500 copies, in demy 4to, 2 rs. net.

STILLMAN (THOS. B.), M.Sc., Ph.D. Engineering Chemistry. $4^{\text {th }}$ Edition. The 4th edition has been mostly rewritten and altered to incorporate the latest approved methods of chemical testing. Medium 8vo. With 147 Figures in the text. 2 Is. net.

STOCKER (R. DIMSDALE). Social Idealism. Crown 8vo, cloth. 3s. net.

I4 Henrietta Street, Covent Garden, London, W.C. 
STRACHEY (G. L.). Landmarks in French Literature. F'cap. 8vo, cloth, Is. net ; leather, 2s. 6d. net. Forming Vol. 35 in the Home University Library ; for list, see p. 35.

TAYLOR (Rev. Dr J.). The Massoretic Text and the Ancient Versions of the Book of Micah. Crown 8vo, cloth. 5 s.

TEN SERVICES OF PUBLIC PRAYER, with Special Collects. 8vo, cloth, 3 s. ; or $32 \mathrm{mo}$, cloth, is. 6 d.

PSALMS AND CANTICLES. 8vo, cloth. Is. 6d. PSALMS AND CANTICLES, with Anthems. 8vo, cloth. 2S.

SERVICES OF PUBLIC PRAYER, taken in Substance from the Common Prayer for Christian Worship, with a few additional Prayers for particular Days. 8vo, cloth, 2s. 6d.; or $32 \mathrm{mo}$, cloth, Is.

TENNYSON (ALFRED, LORD). The Princess: A Medley. With Six Illustrations beautifully reproduced in colours, and a number in black-and-white, from Original Drawings by Everard Hopkins. Small 4to. 7s. 6d. net.

THOMAS (Rev. J. M. LLOYD). A Free Catholic Church. Crown 8vo, cloth. Is. 6d. net.

THOMSON (J. ARTHUR), M.A. Introduction to Science. F'cap. 8vo, cloth, Is. net; leather, 2s. 6d. net. Forming Vol. 32 in the Home University Library; for list, see p. 35.

and Prof. PATRICK GEDDES. Evolution. F'cap. 8vo, cloth, rs. net ; leather, 2s. 6d. net. Forming Vol. 20 in the Home University Library; for list, see p. 35.

Editor of the Home University Library ; for list, see p. 34.

THURSTON (E. TEMPLE). The "Flower of Gloster." By the well-known Author of "City of Beautiful Nonsense," "Sally Bishop," etc. With six Illustrations faithfully reproduced in colours, and other Illustrations in black-and-white, from drawings by W. R. Dakin. Small 4to, cloth. 7s. 6d. net.

TISCHENDORF (C.). The New Testament. Novum Testamentum Græce. 3 vols. 8vo. 70 os. net.

TOWER (O. F.), Ph.D. The Conductivity of Liquids. 8vo. Pages iv + 190. 20 Illustrations. 6s. 6d. net.

TRANSACTIONS OF THE ROYAL DUBLIN SOCIETY. Issued in parts at various prices.

TRANSACTIONS OF THE ROYAL IRISH ACADEMY, DUBLIN. Vols. I.-XX. 4to. $£_{22,}$ 5s. 6d. Vols. XXI.XXXI. Various prices.

TRANSACTIONS OF THE ROYAL SOCIETY OF EDINBURGH. Issued in parts at various prices. General Index to First Thirty-four Volumes ( $1783-1888)$, with History of the Institution. 4to, cloth. 2 Is. 
TRENCKNER (V.). Pali Miscellany. Part I. The Introductory Part of the Milanda Panho, with an English Translation and Notes. 8vo, sewed. 4 s.

TRENT (Prof. W. P.) and ERSKINE (Prof. J.). Great Writers of America. F'cap. 8vo, cloth, Is. net; leather, 2s. 6d. net. Forming Vol. $5^{2}$ of the Home University Library; for list, see p. 36. TROELTSCH (Prof. ERNEST), of Jena. Protestantism and Progress: The Significance of Protestantism in the Rise of the Modern World. Translated into English by Rev. W. Montgomery, B.D. See Crown Theological Library, p. 33.

UPTON (Rev. C. B.). On the Bases of Religious Belief. Hibbert Lectures, 1893. Demy 8vo, cloth. Ios. 6d. Cheap Edition, 3s. 6d.

VEGA. Logarithmic Tables of Numbers and Trigonometrical Functions. Translated from the 4oth, or Dr Bremiker's Edition, thoroughly revised and enlarged, by IV. L. Fischer, M.A., F.R.S., Fellow of Clare College, Cambridge; Professor of Natural Philosophy in the University of St Andrews. 75th Stereotyped Edition. Royal 8vo, cloth. $7 \mathrm{~s}$.

VEILED FIGURE, THE, and other Poems. Large post 8vo, buckram, gilt, cover designed by Mr T. Blake Wirgman. 2s. 6d.

VELASQUEZ. Large Spanish Dictionary. Composed from the Dictionaries of the Spanish Academy, Terreros and Salva. SpanishEnglish and English-Spanish. 1279 pp., triple columns. 2 vols. in I. Imp. 8vo, cloth. $24 \mathrm{~s}$.

VENABLE (T. C.), Ph.D. The Development of the Periodic Law. Small r2mo. Pages viii $+32 \mathrm{I}$. Illustrated. ros. 6d. net.

The Study of the Atom. I 2 mo. Pages vi +290 . 8s. 6d. net. and HOWE. Inorganic Chemistry according to the Periodic Law. 2nd Edition. See under Howe, p. I2.

VINCENT (JACQUES). Vaillante. 2s. 6d. See Army Series of French and German Novels, p, 3 I.

WALFORD (Mrs L. B.). Recollections of a Scottish Novelist. With Portraits and other Illustrations. Demy 8vo, cloth. Ios.6d.net.

WALLACE (Dr ALFRED RUSSEL). See Character and Life, p. 4.

WEINEL (Prof. H.), of the University of Jena. St Paul: The Man and his Work. Translated by Rev. G. A. Bienemann, M.A. Edited by Rev. W. D. Morrison, M.A., LL.D. Demy 8vo, cloth. ros. 6d. See Theological Translation Library, New Series, p. 38.

WEIR (T. H.), B.D. A Short History of the Hebrew Text of the Old Testament. By Thomas H. Weir, Assistant to the Professor of Oriental Languages in the University of Glasgow. 2nd Edition, with Additions. Crown 8vo, cloth. 6s.

WEISSE (T. H.). A Short Guide to German Idioms : being a Collection of the Idioms most in use. With Examination Papers. 3rd Edition. Cloth. 25. 
WEISSE (T. H.). Elements of German. With a Course of Exercises instructing in Simpler Composition. Crown 8vo, cloth. $3 \mathrm{~s}$.

WEIZSÄCKER (Prof. CARL VON). The Apostolic Age. Translated by James Millar, B.D. Demy 8vo, 2 vols., cloth. Each Ios. 6d. See Theological Translation Library, New Series, p. 38.

WELD (A. G.). Glimpses of Tennyson and of Some of his Friends. With an Appendix by the late Bertram Tennyson. Illustrated with Portraits in photogravure and colour, and with a facsimile of a MS. poem. F'cap. 8vo, art linen. 4s. 6d. net.

WERNER (A.) and G. HUNT. Elementary Lessons in Cape Dutch (Afrikander Taal). I6mo, cloth. Is. 6d.

WERNLE (PAUL). The Beginnings of Christianity. The Author is Professor Extraordinary of Modern Church History at the University of Basel. Revised by the Author, and translated by the Rev. G. A. Bienemann, M.A., and edited, with an Introduction, by the Rev. W. D. Morrison, LL.D. Demy 8vo. Ios. 6d. per volume. See Theological Translation Library, New Series, p. 38. WHITEHEAD (A. N.), Sc.D., F.R.S. Introduction to Mathematics. With Diagrams. F'cap. 8vo, cloth, Is. net; leather, 2s. 6d. net. Forming Vol. 18 in the Home University Library; for list, see p. 35 . WILEY (HARVEY W.), A.M., Ph.D. Principles and Practice of Agricultural Chemical Analysis. 3 Vols. 8vo. New Edition in preparation. Vol. I. Soils. Ready. I8s. net. Vol. II. Fertilisers. 20s. net. Vol. III. in active preparation.

WILLIAMS (The Right Rev. W. L.), D.C.L. A Dictionary of the New Zealand Language. 4th Edition. Edited by the Right Rev. Bishop W. L. Williams, with numerous additions and corrections. Demy 8vo, cloth. I2s. 6d.

- Lessons in Maori. 3 rd Edition. F'cap. 8vo, cloth. 3s.

WIMMER(R.), Pastor of Weisweil-am-Rhein in Baden. My Struggle for Light: Confessions of a Preacher. Crown 8vo, cloth. 3s. net. See Crown Theological Library, p. $3 \mathbf{I}$.

WINSTEDT (E. O.), Edited by. Coptic Texts on St Theodore the General, St Theodore the Eastern, Chamoul and Justus. 2 Is. net. See Text and Translation Society, p. 37.

WOODS (C. E.). The Gospel of Rightness. A Study in Pauline Philosophy. 300 pages, cloth. 5 s. net.

WRIGHT (Rev. C. H. H.). Light from Egyptian Papyri on Jewish History before Christ. Crown 8vo, cloth. 3s. net.

WRIGHT (G. H. BATESON), D.D. The Book of Job. A new critically revised Translation, with Essays on Scansion, Date, etc. $8 \mathrm{vo}$, cloth. $6 \mathrm{~s}$.

Was Israel ever in Egypt? or, A Lost Tradition. 8vo, art linen. 7s. 6d.

WRIGHT (W. ALDIS), LL.D., Edited by. A Rabbinic Commentary on the Book of Job, contained in a unique MS. at Cam. bridge. With Translation and Commentary. 2 Is. net. See Text and Translation Society, p. 37 . 
WUNDT (WILHELM). Outlines of Psychology. Translated, with the co-operation of the Author, by Charles Hubbard Judd, $\mathrm{Ph} . \mathrm{D}$., Instructor in the Wesleyan University. 3rd Enlarged Edition. Demy 8vo, cloth. 8s. net.

WYSOR (HENRY), B.S., Assistant Professor of Analytical Chemistry, Lafayette College. Metallurgy. A Condensed Treatise. Demy 8vo, cloth. I 2s. 6d. net.

YOUNGHUSBAND (Col. Sir FRANCIS E.), K.C.I.E. Within: Thoughts during Convalescence. 3s. 6d. net.

\section{COMPLETE LIST OF LIBRARIES AND SERIES ARRANGED IN ALPHABETICAL ORDER.}

\section{ARMY SERIES OF FRENCH AND GERMAN NOVELS. \\ Edited, with short Notes, by J. T. W. Perowne, M.A.}

This series is equally well adapted for general reading, and for those preparing for the Army, Oxford and Cambridge Certificates, and other Examinations-in fact, for all who wish to keep up or improve their French and German. The notes are as concise as possible, with an occasional etymology or illustration to assist the memory. The books selected being by recent or living authors, are adapted for the study of most modern French and German.

Le Coup de Pistolet, etc. Prosper Merimée. 2s. 6d.

Vaillante. Jacques Vincent. 2s. 6d.

Auf Verlornem Posten and Nazzarena Danti. Johannes v. Dewall. 3 s.

Contes Militaires. A. Daudet. 2s. 6d.

Erzählungen. E. Höfer. 3s.

\section{CROWN THEOLOGICAL LIBRARY.}

The only undertaking of its kind in the English language; each writer is at liberty to express his deepest convictions with absolute freedom - a freedom which is the only ultimate security of truth.

Vol. I.-Babel and Bible. By Dr Friedrich Delitzsch. 4s. 6 d. net.

Vol. II.-The Virgin Birth of Christ. An Historical and Critical Essay. By Paul Lobstein. 2s. 6d. net.

Vol. III.-My Struggle for Light. Confessions of a Preacher. By R. Wimmer. 3s. net.

Vol. IV.-Liberal Christianity. Its Origin, Nature, and Mission. By Jean Réville. 3s. 6d. net.

Vol. V.-What is Christianity? By Adolf Harnack. 4s. 6d. net.

Vol. VI.-Faith and Morals. By W. Herrmann. 4s. 6d. net. 
Crown Theological Library-continued.

Vol. VII. - Early Hebrew Story. A Study of the Origin, the Value, and the Historical Background of the Legends of Israel. By John P. Peters, D.D. 4s. 6d. net.

Vol. VIII.-Bible Problems and the New Material for their Solution. By Prof. T. K. Cheyne, D.Litt., D.D. 4s. 6d. net.

Vol. IX.-The Doctrine of the Atonement and its Historical Evolution, and Religion and Modern Culture. By the late Auguste Sabatier. 4s. net.

Vol. X.- The Early Christian Conception of Christ. Its Significance and Value in the History of Religion. By Otto Pfleiderer. 3s. net.

Vol. XI.-The Child and Religion. Eleven Essays by Various Writers. 5s. net.

Vol. XII.-The Evolution of Religion. An Anthropological Study. By L. R. Farnell, M.A., D.Litt. 4s. 6d. net.

Vol. XIII.- The Books of the New Testament. By Baron Hermann von Soden, D.D. 4S. 6d. net.

Vol. XIV.-Jesus. By W. Bousset. 3s. 6d. net.

Vol. XV.- The Communion of the Christian with God. By W. Herrmann. Revised and much enlarged edition. 4s. 6d. net.

Vol. XVI.-Hebrew Religion. To the Establishment of Judaism under Ezra. By W. E. Addis, M.A. 4S. 6d. net.

Vol. XVII.-Naturalism and Religion. By Rudolf Otto. 5s. net.

Vol. XVIII.-Essays on the Social Gospel. By Dr Adolf Harnack and Dr Herrmann. 4s. net.

Vol. XIX. - The Religion of the Old Testament. By Karl Marti. 4s. net.

Vol. XX.-Luke the Physician. Being Volume One of Dr Adolf Harnack's New Testament Studies. 5s. net.

Vol. XXI.-The Historical Evidence for the Resurrection of Jesus Christ. By Prof. Kirsopp Lake. 4s. 6d. net.

Vol. XXII.-The Apologetic of the New Testament. By E. F. Scott. 4s. 6d. net.

Vol. XXII1.- The Sayings of Jesus. Being Volume Two of Dr Adolf Harnack's New Testament Studies. 5s. net.

Vol. XXIV.-Anglican Liberalism. By Twelve Churchmen. 4s. 6d. net.

Vol. XXV.-The Fundamental Truths of the Christian Religion. By Dr R. Seeberg. 4s. 6d. net.

Vol. XXVI.- The Life of the Spirit. An Introduction to Philosophy. By Dr Rudolf Eucken. 4s. 6d. net.

Vol. XXVII.- The Acts of the Apostles. Being Volume Three of Dr Adolf Harnack's New Testament Studies. 5s. net.

Vol. XXVIII.-Monasticism and the Confessions of St Augustine. By Dr Adolf Harnack. 35. 6d. net.

Vol. XXIX.-Modernity and the Churches. By Prof. Percy Gardner. 4s. 6d. net. 
Crown Theological Library-continued.

Vol. XXX.-The Old Egyptian Faith. By Prof. Edouard Naville. Illustrated. 4s. 6d. net.

Vol. XXXI. - The Constitution and Law of the Church in the First Two Centuries. By Dr Adolf Harnack. 5s. net.

Vol. XXXII.-The Scientific Study of the Old Testament. Illustrated. By Dr Rudolf Kittel. 5s. net.

Vol. XXXIII.- The Date of the Acts and of the Synoptic Gospels. Being Volume Four of Dr Adolf Harnack's New Testament Studies. Cloth. 5s. net.

Vol. XXXIV.-The Religious Experience of St Paul. By Prof. Percy Gardner. 5s. net.

Vol. XXXV.-Pharisaism: Its Aims and its Methods. By R. Travers Herford, B.A. Cloth. 5s. net.

Vol. XXXVI.-Bible Reading in the Early Church. Being Volume Five of Dr Adolf Harnack's New Testament Studies. Cloth. 5s. net.

Vol. XXXVII.-Protestantism and Progress. By Prof. Ernest Troeltsch of Jena.

\section{Descriptive Prospectus on Application.}

\section{THE HIBBERT LECTURES.}

Library Edition, demy 8vo. ros. 6d. per volume.

Cheap Popular Edition, 3s. 6d. per volume.

Alviella (Count Goblet D'). Lectures on the Origin and the Growth of the Conception of God, as illustrated by Anthropology and History. Translated by the Rev. P. H. Wicksteed. (Hibbert Lectures, 1891.) Cloth. 1os. 6d. Cheap Edition, 3s. 6d.

Beard (Rev. Dr C.). Lectures on the Reformation of the Sixteenth Century in its Relation to Modern Thought and Knowledge. (Hibbert Lectures, r 883.) 8vo, cloth. 10s.6d. Cheap Edition, 3s.6d.

Davids (T. W. Rhys). Lectures on Some Points in the History of Indian Buddhism. (Hibbert Lectures, 188r.) and Edition. 8vo, cloth. Ios. 6d. Cheap Edition, 3s. 6d.

Drummond (Dr). Via, Veritas, Vita. Lectures on Christianity in its most Simple and Intelligible Form. (The Hibbert Lectures, 1894.) ros. 6d. Cheap Edition, 3s. 6d.

Hatch (Rev. Dr). Lectures on the Influence of Greek Ideas and Usages upon the Christian Church. Edited by Dr Fairbairn. (Hibbert Lectures, 1888.) 3rd Edition. 8vo, cloth. 1os. 6d. Cheap Edition, 3s. 6d.

Kuenen (Dr A.). Lectures on National Religions and Universal Religion. (The Hibbert Lectures, 1882.) 8vo, cloth. 10s. 6d. Cheap Edition, 3s. 6d.

Montefiore (C. G.). Origin and Growth of Religion as Illustrated by the Religion of the Ancient Hebrews. (The Hibbert Lectures, 1892.) 2nd Edition. 8vo, cloth. 10s. 6d. Cheap Edition, 3s. 6d.

I4 Henrietta Street, Covent Garden, London, W.C. 
The Hibbert Lectures-continued.

Pfleiderer (Dr O.). Lectures on the Influence of the Apostle Paul on the Development of Christianity. Translated by the Rev. J. Frederick Smith. (Hibbert Lectures, 1885.) and Edition. 8vo, cloth. ros. 6d. Cheap Edition, 3s. 6d.

Renan (E.). On the Influence of the Institutions, Thoughts and Culture of Rome on Christianity, and the Development of the Catholic Church. Translated by the Rev. Charles Beard. (Hibbert Lectures, 1880.) 8vo, cloth. Ios. 6d. Cheap Ed., 3rd Ed., 3s. 6d. Renouf (P. Le Page). On the Religion of Ancient Egypt. (Hibbert Lectures, r879.) 3rd Edition. 8vo, cloth. ros. 6d. Cheap Edition, 3s. 6d.

Rhys (Prof. J.). On the Origin and Growth of Religion as Illustrated by Celtic Heathendom. (Hibbert Lectures, 1886.) 8vo, cloth. Ios. 6d. Cheap Edition, 3s. 6d.

Réville (Dr A.). On the Native Religions of Mexico and Peru. Translated by the Rev. P. H. Wicksteed. (Hibbert Lectures, 1884.) 8vo, cloth. ros. 6d. Cheap Edition, 3s. 6d.

Sayce (Prof. A. H.). On the Religion of Ancient Assyria and Babylonia. 4th Edition. (Hibbert Lectures, 1887.) 8vo, cloth. ros. 6d. Cheap Edition, 3s. 6d.

Upton (Rev. C. B.). On the Bases of Religious Belief. (Hibbert Lectures, 1893.) Demy 8vo, cloth. ros. 6d. Cheap Edition, 3s. 6d.

Second Series.

Farnell (L. R.), D.Litt., Wilde Lecturer in the University of Oxford. The Higher Aspects of Greek Religion. Lectures delivered in Oxford and London in I9r r. Demy 8vo, cloth. 6s. net.

\section{HOME UNIVERSITY LIBRARY OF MODERN KNOWLEDGE.}

Editors : Prof. Gilbert Murray, D.Litt., LL.D., F.B.A., Herbert Fisher, M.A., F.B.A., Professor J. Arthur Thomson, and Professor Wm. T. Brewster. Each volume is written by an expert of the very first rank, and consists of $25^{6}$ pages. Issued bound in cloth at rs. net, or beautifully bound in leather, levant morocco grain, $2 \mathrm{~s}$. $6 \mathrm{~d}$. net.

Sixty Volumes Now Ready.

I. Parliament. Sir C. P. Ilbert, K.C.B.

2. Shakespeare. John Masefield.

3. French Revolution. (With Maps.) Hilaire Belloc, M.A.

4. History of War and Peace. G. H. Perris.

5. Stock Exchange. F. W. Hirst, M.A.

6. Irish Nationality. Mrs J. R. Green.

7. Modern Geography. (Illustrated.) Dr M. Newbigin.

8. Polar Exploration. (With Maps.) Dr W. S. Bruce.

9. Evolution of Plants. (Fully Illustrated.) Dr D. H. Scott, F.R.S. 
Home University Library of Modern Knowledge-continued.

Io. Socialist Movement. J. Ramsay MacDonald, M.P.

I I. Conservatism. Lord Hugh Cecil, M.A., M.P.

12. Opening $U_{p}$ of Africa. (With Maps.) Sir H. H. Johnston, G.C.M.G.

13. Mediæval Europe. (With Maps.) H. W. C. Davis, M.A.

14. The Papacy and Modern Times. Rev. Dr W. Barry.

15. Mohammedanism. Prof. D. S. Margoliouth.

I6. The Science of Wealth. J. A. Hobson, M.A.

17. Health and Disease. Dr W. L. Mackenzie.

r8. Introduction to Mathematics. (With Diagrams.) A. N. Whitehead, Sc.D., F.R.S.

19. The Animal World. (With many Illustrations.) Prof. F. W. Gamble.

20. Evolution. Prof. J. A. Thomson and Prof. P. Geddes.

21. Liberalism. Prof. L. T. Hobhouse.

22. Crime and Insanity. Dr C. A. Mercier.

23. History of our Time, I885-I9II. G. P. Gooch, M.A.

24. The Evolution of Industry. Prof. D. H. MacGregor.

25. The Civilisation of China. Prof. H. A. Giles, LL.D.

26. Agriculture. Prof. W. Somerville, D.Sc.

27. English Literature : Modern. George Mair, M.A

28. Psychical Research. Sir W. F. Barrett, F.R.S.

29. The Dawn of History. Prof. J. L. Myers.

30. Elements of English Law. Prof. W. M. Geldart, B.C.L.

31. Astronomy. A. R. Hinks, M.A. M.A.

32. The Introduction to Science. Prof. J. Arthur Thomson,

33. The History of England: A Study in Political Evolution. Prof. A. F. Pollard.

34. Canada. A. G. Bradley.

35. Landmarks in French Literature. G. L. Strachey.

36. Climate and Weather. (With Diagrams.) Prof. H. N. Dickson, D.Sc. K.C.S.I.

38. The School. An Introduction to the Study of Education Prof. J. J. Findlay.

39. Architecture. (Over 40 Illustrations.) Prof. W. R. Lethaby.

40. Problems of Philosophy. The Hon. Bertrand Russell, F.R.S.

4I. Anthropology. R. R. Marett, M.A.

42. Rome. W. Warde-Fowler, M.A.

43. English Literature : Mediæval. Prof. W. P. Ker.

44. Principles of Physiology. Prof. J. G. M'Kendrick.

45. The English Language. J. Pearsall Smith, M.A.

46. Matter and Energy. F. Soddy, F.R.S.

47. Buddhism. Mrs Rhys Davids.

48. The American Civil War. (Maps.) Prof. F. L. Paxson. 
Home University Library of Modern Knowledge-continued.

49. Psychology. The Study of Behaviour. Prof. W. McDougall.

50. Nonconformity, Its Origin and Progress. Principal W. B. Selbie.

5I. Warfare in England. (With Maps.) Hilaire Belloc, M.A.

52. Great Writers of America. Profs. W. P. Trent and J. Erskine.

53. The Making of the Earth. (With 38 Maps and Figures.) Prof. J. W. Gregory, F.R.S.

54. Ethics. G. E. Moore, M.A.

55. Master Mariners. J. R. Spears.

56. Making of the New Testament. Prof. B. W. Bacon, LL.D., D.D.

57. The Human Body (Illustrated). Prof. Arthur Keith, M.D., F.R.C.S.

58. Electricity (Illustrated). Dr Gisbert Kapp, D.Eng., M.I.E.E.

59. Political Economy. Prof. S. J. Chapman, M.A.

60. Missions: Their Rise and Development. Mrs Creighton

\section{A Detailed List, containing Particulars of more than One Hundred Volumes, to be had on application.}

LIVERPOOL MARINE BIOLOGY COMMITTEE. MEMOIRS ON TYPICAL BRITISH MARINE PLANTS AND ANIMALS. Edited by W. A. Herdman, D.Sc., F.R.S. All demy 8 vo, stiff boards.

I. Ascidia. By W. A. Herdman. With 5 Plates. 2s. net.

2. Cardium. By J. Johnstone, Fisheries Assistant, University College, Liverpool. With 7 Plates. 2s. 6d. net.

3. Echinus. By Herbert Clifton Chadwick, Curator of the Port Erin Biological Station. With 5 Plates. 2s. net.

4. Codium. By R. J. Harvey Gibson, M.A., F.L.S., Professor of Botany in University College, Liverpool, and Helen P. Auld, B.Sc. With 3 Plates. Is. 6d. net.

5. Alcyonium. By Sydney J. Hickson, M.A., D.Sc., F.R.S., Beyer Professor of Zoology in Owens College, Manchester. With 3 Plates. Is. 6d. net.

6. Lepeophtheirus and Lernea. By Andrew Scott, Resident Fisheries Assistant at the Peel Hatchery. With 5 Plates. 2s. net.

7. Lineus. By R. C. Punnett, B.A. With 4 Plates. 2s. net.

8. Pleuronectes. By Frank J. Cole, Jesus College, Oxford, Lecturer in the Victoria University, Demonstrator of Zoology, University, Liverpool, and James Johnstone, B.Sc. Lond., Fisheries Assistant, University, Liverpool. With I I Plates. 7s. net.

9. Chondrus. By Otto V. Darbishire, Owens College, Manchester. With 7 Plates. 2s. 6d. net. 
Liverpool Marine Biology Committee Memoirs-continued.

10. Patella (the Common Limpet). By J. R. Ainsworth Davis, M.A., Professor of Zoology in the University College of Wales, Aberystwyth, and H. J. Fleure, B.Sc., Fellow of the University of Wales. With 4 Plates. 2s. 6d. net.

I I. Arenicola (the Lug-Worm). By J.H. Ashworth, D.Sc., Lecturer in Invertebrate Zoology in the University of Edinburgh. With 8 Plates. 4s. 6d. net.

12. Gammarus. By Margaret Cussans, B.Sc., Zoological Department, University of Liverpool. With 4 Plates. 2s. net.

13. Anurida. By A. D. Imms, B.Sc. (Lond.). With 7 Plates. 4s. net.

14. Ligia. By C. Gordon Hewitt, B.Sc., Demonstrator in Zoology, University of Manchester. With 4 Plates. 2s. net.

15. Antedon. By Herbert Clifton Chadwick. With 7 Plates. 2s. 6d. net.

16. Cancer. By Joseph Pearson, M.Sc., Demonstrator in Zoology, University of Liverpool. With I 3 Plates. 6s. 6d. net.

17. Pecton. By W. J. Dakin, M.Sc. With 9 Plates. 4s. 6d. net.

18. Eledone. By Annie Isgrove, M.Sc. With Io Plates. 4s. 6d. net.

19. Polychaet Larvae. By F. H. Gravely, M.Sc. With 4 Plates. 2s. 6d. net.

TEXT AND TRANSLATION SOCIETY. Established for the purpose of editing and translating Oriental Texts chiefly preserved in the British Museum.

The Sixth Book of the Select Letters of Severus, Patriarch of Antioch, in the Syriac Version of Athanasius of Nisibis. Edited and translated by E. W. Brooks, M.A. Vol. I. Text, Parts I. and II. Vol. II. Translation, Parts I. and II. 84s. net.

The Canons of Athanasius of Alexandria, in Arabic, Ethiopic, and Coptic. Edited and translated by Prof. W. Riedel (Griefswald) and W. E. Crum. 2is. net.

A Rabbinic Commentary on the Book of Job, contained in a unique MS. at Cambridge. Edited, with Translation and Commentary, by W. Aldis Wright, LL.D. 2 rs. net.

An Ancient Armenian Version of the Apocalypse of St John; also The Armenian Texts of Cyril of Alexandria, Scholia de Incarnatione and Epistle to Theodosius upon Easter, the former incompletely preserved in Greek, the latter unknown in Greek or Latin. All edited, with English versions, etc., by F. C. Conybeare, formerly Fellow of University College, Oxford.

Remnants of the Later Syriac Versions of the Bible. Part I. (Sixth Century). The Four Minor Catholic Epistles. Reconstructed Text, with Apparatus Criticus. Part II. (Seventh Century). Extracts, hitherto unedited, from the Syro-Hexaplar 
Text and Translation Society-continued.

Text of Chronicles, Nehemiah, etc. All edited, with Greek versions, etc., by John Gwynn, D.D., Regius Professor of Divinity, Dublin. 2 rs. net.

Coptic Texts on St Theodore the General, St Theodore the Eastern, Chamoul and Justus. Edited and Translated by E. O. Winstedt, late Senior Demy of Magdalen College, Oxford. 2 Is. net.

The Refutation of Mani, Marcion, and Bardaisan of St Ephraim. Edited by the Rev. C. W. Mitchell. 2 Is. net.

\section{THEOLOGICAL TRANSLATION LIBRARY.}

New Series. A Series of Translations by which the best results of recent Theological Investigations on the Continent, conducted without reference to doctrinal considerations, and with the sole purpose of arriving at the truth, are placed within reach of English readers.

Vols. I. and V.-The Apostolic Age. By Prof. Carl von Weizsäcker. Translated by James Millar, B.D. 2 vols. Ios. 6d. each.

Vols. II., VII., VIII., IX., X., XI., XII.-A History of Dogma. By Adolf Harnack, Berlin. Translated from the Third German Edition. Edited by the late Rev. Prof. A. B. Bruce, D.D. 7 vols. Ios. 6 d. each.

Vols. III. and VI.-A History of the Hebrews.-By R. Kittel, Ordinary Professor of Theology in the University of Breslau. Ios. 6d. per volume.

Vol. IV.- The Communion of the Christian with God : A Discussion in Agreement with the View of Luther. By W. Herrmann, Dr Theol., Professor of Dogmatic Theology in the University of Marburg. Ios. 6d. net.

Vol. XIII. - An Introduction to the Textual Criticism of the Greek New Testament. By Prof. Eberhard Nestle, of Maulbronn. Cloth, ros. 6d.; half leather, r 2s. 6d.

Vols. XV. and XVII.-The Beginnings of Christianity. By Paul Wernle, Professor Extraordinary of Modern Church History at the University of Basal. Vol. I. The Rise of the Religion. Vol. II. The Development of the Church. ros. 6d. per volume.

Vol. XVI.-The Religions of Authority and the Religion of the Spirit. By the late Auguste Sabatier. 1os. 6d.

Vol. XVIII.-Christian Life in the Primitive Church. By Ernst von Dobschütz, D.D., Professor of New Testament Theology in the University of Strassburg. ros. 6d.

Vols. XIX. and XX. - The Mission and Expansion of Christianity in the First Three Centuries. By Adolf Harnack, Berlin. Second, revised and much enlarged edition, 25 s. net. Vols. not sold separately.

Vol. XXI.-St Paul: The Man and his Work. By Prof. H. Weinel, of the University of Jena. Ios. 6d. 
Theological Translation Library-continued.

Vols. XXII., XXVI., XXVII., and XXXI.-Primitive Christianity: Its Writings and Teachings in their Historical Connections. By Otto Pfleiderer, Professor of Practical Theology in the University of Berlin. 4 vols. Ios. 6d. each net.

Vol. XXIII.-The Introduction to the Canonical Books of the Old Testament. By Carl Cornill, Professor of Old Testament Theology at the University of Breslau. Ios. 6d. net.

Vol. XXIV.- History of the Church. By Hans von Schubert, Professor of Church History at Kiel. Ios. 6d. net.

Vol. XXV.-Ethics of the Christian Life. By Theodor von Haering, Professor of New Testament Dogmatics and Ethics at Tübingen. ros. 6 d. net.

Vols. XXVIII. and XXIX.- TheOld Testament in the Light of the Ancient East. By Alfred Jeremias, Pastor of the Lutherkirche, and Lecturer at the University of Leipzig. With numerous illustrations and maps, $25 \mathrm{~s}$. net. Vols. not sold separately.

Vol. XXX.-The Truth of Religion. By Dr Rudolf Eucken, Senior Professor of Philosophy in the University of Jena. I 2s. 6d. net.

Vol. XXXII.-Religious Liberty. By Prof. Francesco Ruffini. With a Preface to the English Edition by Prof. J. B. Bury of Cambridge. Demy 8vo, cloth. r2s. 6d. net.

\section{THEOLOGICAL TRANSLATION FUND LIBRARY.}

Old Series. Uniform Price per Volume, 6s.

Baur (F. C.). Church History of the First Three Centuries. Translated from the Third German Edition. Edited by Rev. Allan Menzies. 2 vols. 8vo, cloth. I 2s.

- Paul, the Apostle of Jesus Christ, His Life and Work, His Epistles and Doctrine. A Contribution to a Critical History of Primitive Christianity. Edited by Rev. Allan Menzies. 2nd Edition. 2 vols. 8vo, cloth. I $2 \mathrm{~s}$.

Ewald's (Dr H.) Commentary on the Prophets of the Old Testament. Trans. by the Rev. J. F. Smith. 5 vols. 8vo, cloth. 3 os.

Commentary on the Psalms. Translated by the Rev. E. Johnson, M.A. 2 vols. 8 vo, cloth. $12 \mathrm{~s}$.

- Commentary on the Book of Job, with Translation. Translated from the German by the Rev. J. Frederick Smith. $8 \mathrm{vo}$, cloth. 6s.

Hausrath (Prof. A.). History of the New Testament Times. The Time of Jesus. Translated by the Revs. C. T. Poynting and P. Quenzer. 2 vols. 8vo, cloth. I $2 \mathrm{~s}$.

Keim's History of Jesus of Nazara : Considered in its connection with the National Life of Israel, and related in detail. Translated from the German by Arthur Ransom and the Rev. E. M. Geldart. Complete in 6 vols. 8vo. 36s. (Vol. I. only to be had when a complete set of the work is ordered.) 
Theological Translation Fund Library-continued.

Kuenen(Dr A.). The Religion of Israel to the Fall of the Jewish State. Trans. from the Dutch by A. H. May. 3 vols. 8 vo, cloth. I 8 s.

Pfleiderer (O.). Paulinism : A Contribution to the History of Primitive Christian Theology. Translated by E. Peters. 2nd Edition. 2.vols. 8vo, cloth. I2s.

- Philosophy of Religion on the Basis of its History. Translated by Prof. Allan Menzies and the Rev. Alex. Stewart. 4 vols. $8 \mathrm{vo}$, cloth. 24s. (Vol. I. out of print.)

Réville (Dr A.). Prolegomena of the History of Religions. With an Introduction by Prof. F. Max Müller. 8vo, cloth. 6s.

Schrader (Prof. E.). The Cuneiform Inscriptions and the Old Testament. Translated from the Second Enlarged Edition, with Additions by the Author, and an Introduction by the Rev. Owen C. Whitehouse, M.A. 2 vols. With a Map. 8vo, cloth. I2s.

\section{LIST OF PERIODICALS, REVIEWS, AND TRANS-} ACTIONS AND PROCEEDINGS OF LEARNED SOCIETIES published by Williams \& Norgate.

The Hibbert Journal: A Quarterly Review of Religion, Theology, and Philosophy. Single numbers, 2s. 6d. net. Subscription, ros. per annum, post free.

Journal of the Federated Malay States Museums. Issued quarterly. Single numbers, Is. 6d. net Subscription, 5s. per annum.

Journal of the Royal Microscopical Society, containing its Transactions and Proceedings, with other Microscopical Information. Bi-monthly. 6s. net. Yearly subscriptions, 37s. 6d., post free.

Journal of the Quekett Microscopical Club. Issued halfyearly, April and November. Price 3s. 6d. net. 7s. 6d. per annum, post free.

Linnean Society of London. Journal of Botany and Journal of Zoology. Published irregularly at various prices. Also Transactions, published irregularly.

Royal Society of Edinburgh. Transactions. Issued irregularly at various prices.

Liverpool Marine Biology Committee. Memoirs. I.-XIX. already published at various prices. Fauna of Liverpool Bay. Fifth Report, written by Members of the Committee and other Naturalists. Cloth. 8s. 6d. net. See p. 36 .

Publications de l'Institut Nobel Norvégien. Vol. I. L'Arbitrage International chez les Hellènes. Par A. Raedar. 4to. Ios. net.

Royal Irish Academy. Transactions and Proceedings issued irregularly; prices vary. Cunningham Memoirs. Vols. I.-XI. already issued at various prices. See p. 28 .

Royal Dublin Society. Transactions and Proceedings. Issued irregularly at various prices. 




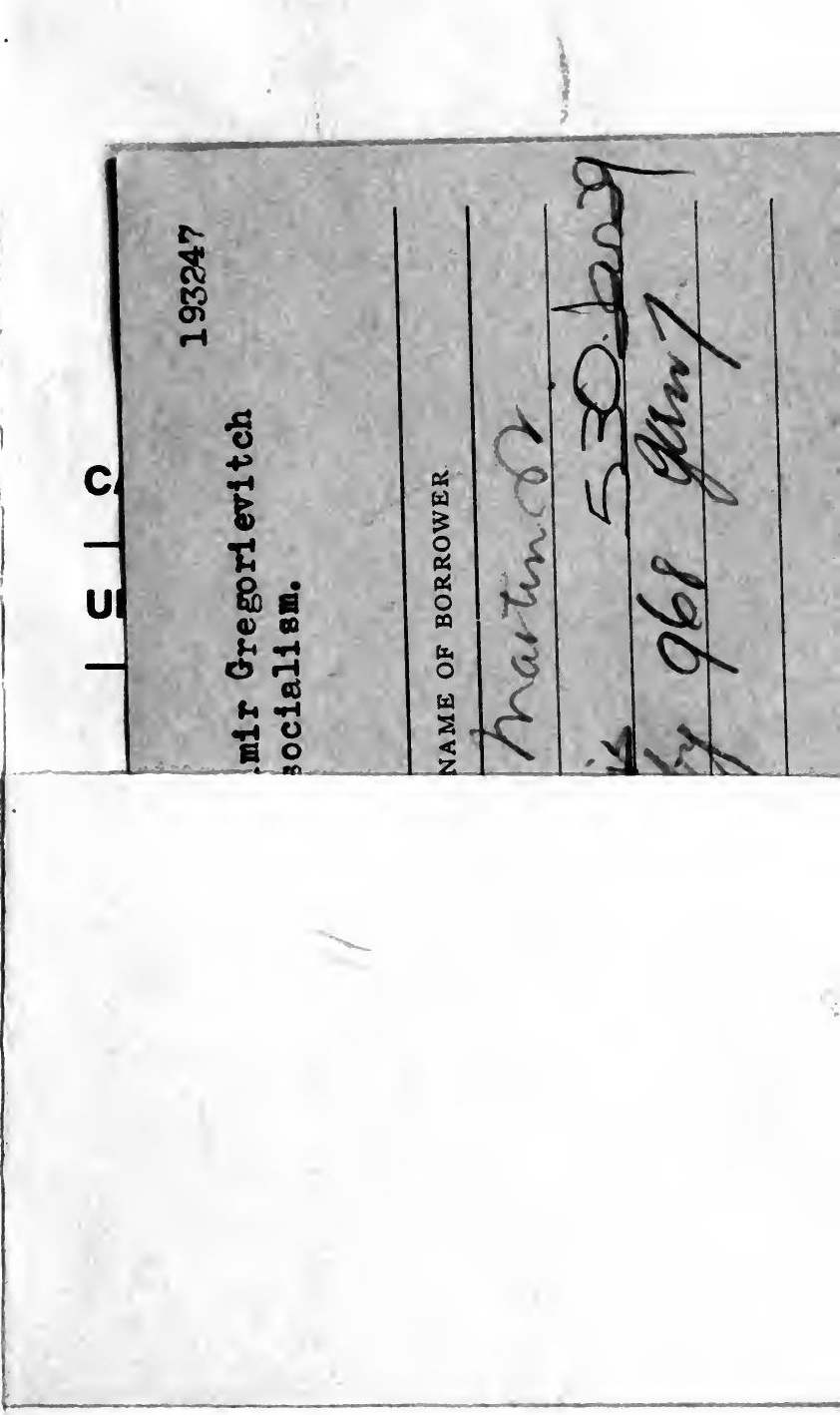


